VILNIAUS GEDIMINO TECHNIKOS UNIVERSITETAS

Michail POPOV

\title{
TAMPRIŲ PLASTINIŲ GEOMETRIŠKAI NETIESINIŲ STRYPINIŲ KONSTRUKCIJŲ OPTIMIZAVIMAS RIBOJANT POSLINKIUS
}

DAKTARO DISERTACIJA

TECHNOLOGIJOS MOKSLAI, STATYBOS INŽINERIJA (02T)

Vilnius TECHNIKA 2014
} 
Disertacija rengta 2006-2014 metais Vilniaus Gedimino technikos universitete.

Disertacija ginama eksternu.

\section{Mokslinis konsultantas}

prof. habil. dr. Juozas ATKOČIŪNAS (Vilniaus Gedimino technikos universitetas, statybos inžinerija - 02T).

\section{Mokslinis vadovas (2006-2010)}

prof. dr. Romanas KARKAUSKAS (Vilniaus Gedimino technikos universitetas, statybos inžinerija - 02T).

Vilniaus Gedimino technikos universiteto Statybos inžinerijos mokslo krypties disertacijos gynimo taryba:

\section{Pirmininkas}

prof. habil. dr. Gintaris KAKLAUSKAS (Vilniaus Gedimino technikos universitetas, statybos inžinerija - 02T).

\section{Nariai:}

dr. Raimondas BLIŪDŽIUS (Kauno technologijos universitetas, statybos inžinerija - 02T),

prof. dr. Jaan LELLEP (Tartu universitetas, mechanikos inžinerija - 09T), prof. dr. Arnoldas NORKUS (Vilniaus Gedimino technikos universitetas, statybos inžinerija - 02T),

prof. habil. dr. Henrikas SIVILEVIČIUS (Vilniaus Gedimino technikos universitetas, statybos inžinerija - 02T).

Disertacija bus ginama viešame Statybos inžinerijos mokslo krypties disertacijos gynimo tarybos posedyje 2014 m. birželio 16 d. 14 val. Vilniaus Gedimino technikos universiteto senato posèdžių salèje.

Adresas: Saulètekio al. 11, LT-10223 Vilnius, Lietuva.

Tel.: (8 5) 274 4956; faksas (8 5) 270 0112; el. paštas doktor@vgtu.lt

Pranešimai apie numatomą ginti disertaciją išsiųsti $2014 \mathrm{~m}$. gegužès $15 \mathrm{~d}$.

Disertaciją galima peržiūreti interneto svetainejje http://dspace.vgtu.lt/ ir Vilniaus Gedimino technikos universiteto bibliotekoje (Saulètekio al. 14, LT-10223 Vilnius, Lietuva).

VGTU leidyklos TECHNIKA 2251-M mokslo literatūros knyga

ISBN 978-609-457-686-7

(C) VGTU leidykla TECHNIKA, 2014

(C) Michail Popov, 2014

michail.popov@vgtu.lt 
VILNIUS GEDIMINAS TECHNICAL UNIVERSITY

Michail POPOV

OPTIMIZATION OF GEOMETRICALLY NONLINEAR ELASTIC PLASTIC FRAMEWORK STRUCTURES UNDER DISPLACEMENT CONSTRAINTS

DOCTORAL DISSERTATION

TECHNOLOGICAL SCIENCES, CIVIL ENGINEERING (02T)

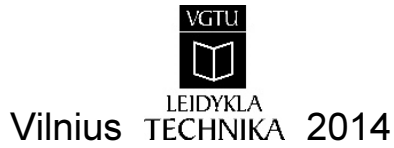


Doctoral dissertation was prepared at Vilnius Gediminas Technical University in 2006-2014.

The dissertation is defended as an external work.

\section{Scientific Consultant}

Prof Dr Habil Juozas ATKOČIŪNAS (Vilnius Gediminas Technical University, Civil Engineering - 02T).

\section{Supervisor (2006-2010)}

Prof Dr Romanas KARKAUSKAS (Vilnius Gediminas Technical University, Civil Engineering - 02T).

The Dissertation Defense Council of Scientific Field of Civil Engineering of Vilnius Gediminas Technical University:

\section{Chairman}

Prof Dr Habil Gintaris KAKLAUSKAS (Vilnius Gediminas Technical University, Civil Engineering - 02T).

\section{Members:}

Dr Raimondas BLIŪDŽIUS (Kaunas University of Technology, Civil Engineering - 02T),

Prof Dr Jaan LELLEP (Tartu University, Mechanical Engineering - 09T), Prof Dr Arnoldas NORKUS (Vilnius Gediminas Technical University, Civil Engineering - 02T),

Prof Dr Habil Henrikas SIVILEVIČIUS (Vilnius Gediminas Technical University, Civil Engineering - 02T).

The dissertation will be defended at the public meeting of the Dissertation Defense Council of Civil Engineering in the Senate Hall of Vilnius Gediminas Technical University at 2 p. m. on 16 June 2014.

Address: Sauletekio al. 11, LT-10223 Vilnius, Lithuania.

Tel.: +370 5274 4956; fax +370 5270 0112; e-mail: doktor@vgtu.lt

A notification on the intend defending of the dissertation was send on 15 May 2014.

A copy of the doctoral dissertation is available for review at the Internet website http://dspace.vgtu.lt/ and at the Library of Vilnius Gediminas Technical University (Sauletekio al. 14, LT-10223 Vilnius, Lithuania). 


\section{Reziumè}

Disertaciniame darbe aprašyti autoriaus sudaryti geometriškai netiesinių tamprių plastinių statybinių strypinių konstrukcijų skaičiavimo ir optimizavimo uždavinių, ribojant konstrukcijos poslinkius, matematiniai modeliai. Sukurtas geometriškai netiesinių erdvinių strypinių konstrukcijų optimizavimo, ribojant poslinkius, uždavinio sprendimo originalus algoritmas. Disertaciją sudaro įvadas, trys skyriai, rezultatų apibendrinimas, naudotos literatūros ir autoriaus publikacijų disertacijos tema sąrašai bei 8 priedai.

Ivadiniame skyriuje aptariama tiriamoji problema, aprašomas tyrimu objektas ir metodai, formuluojamas darbo tikslas bei uždaviniai, aprašomas darbo mokslinis naujumas bei aktualumas, darbo rezultatų praktinè reikšmè. Ivado pabaigoje pristatomos disertacijos tema autoriaus paskelbtos publikacijos ir pranešimai konferencijose bei disertacijos struktūra.

Pirmajame skyriuje analizuojamos projektavimo ir konstrukciju optimizavimo uždavinių sąsajos, pateikiama trumpa konstrukcijų optimizavimo metodų analitinè apžvalga. Nagrinejjama netamprių geometriškai netiesinių plieninių rèminių konstrukcijų optimizavimo ribojant poslinkius problematika. Aprašomos pasirinktos pagrindinès prielaidos ir fizinès priklausomybès bei dydžiai, apibrežiantys konstrukcijos ittemptaji-deformuotajji būvị (IDD). Pateikiamas konstrukcijų optimizavimo uždavinio matematinis modelis. Pasiūlomas algoritmas šiam uždaviniui spręsti. Apžvelgiamos optimizavimo uždavinio skaitinès realizacijos galimybès.

Antrajame skyriuje pateikiami tikrojo IDB nustatymo metodai - tampraus skaičiavimo netiesinè analizė bei tamprių plastinių konstrukcijų analizè. Pristatomas šių metodų formulavimas, reikalingų dydžių nustatymas bei skaitinès realizacijos galimybès. Pagrindžiamas ekstreminio energinio principo taikymas sprendžiant optimizavimo uždavinius. Pateikiami skaitinio eksperimento rezultatai.

Trečiajame skyriuje pateikiamas konstrukcijų optimizavimo uždavinio, ribojant poslinkius, matematinis modelis. Detalizuojma optimizavimo uždavinio sprendimo strategija: poslinkių kitimo metodika, išplèstinio algoritmo konvergencijos kokybè, vystantis geometriniam netiesiškumui. Pateikiami skaitinio eksperimento pagal siūlomą išplèstinį algoritmą rezultatai.

Disertacijos tema paskelbti 7 straipsniai: vienas - straipsniu rinkinyje, įtrauktame ị Thomson ISI sąrašą, trys - kitose duomenų bazėse; du - tarptautinių konferencijų medžiagose; vienas - Lietuvos konferencijos medžiagoje. Disertacijos tema perskaityti 6 pranešimai Lietuvos bei kitų šalių konferencijose. 


\section{Abstract}

The optimization mathematical models of geometrically nonlinear elastic plastic frameworks structures optimization under displacement constraints are created in the thesis. Original solution algorithm was created for the optimization of geometrically nonlinear elastic-plastic frameworks structures under displacement constraints. The dissertation consists of introduction, 3 chapters, conclusions, references and 8 annexes.

The introduction reveals the investigated problem, the object of research and describes the purpose and tasks of the thesis, research methodology, scientific novelty, the practical significance of results examined in the thesis. The introduction ends in presenting the author's publications on the subject of the defended dissertation, offering the material of made presentations in conferences and defining the structure of the dissertation.

Construction design and structures optimization problems correlation is describing in chapter 1 . Short historical review of optimization methods and structures optimization analytical analysis are presented. Reviewing problematic of non-elastic geometrically nonlinear steel frame structures optimization under displacements constraints. Describing basic accepted assumptions and physical dependences and values describing structures real stress-strain state (SSS). Structure optimization problem mathematical model is presented. Algorithm for such optimization problem solution is suggested. Optimization problem numerical realization possibilities are presented.

Elastic calculation nonlinear analysis and elastic plastic structure's analysis - methods for real structure's stress-strain state determination are presented in chapter 2 . Methods formulation, necessary values determination and possibility of numerical realization are presented. Usage of extreme energy principle for optimization problems substantiated. Numerical experiment results are presented.

Structure optimization under displacements constraints problem mathematical model is presented in chapter 3. Strategy of optimization problem calculation is detailed: displacements variation methodic, and extended algorithm convergence quality for geometrical nonlinearity occurring. Results of numerical experiment by suggesting algorithm are presented.

7 articles focusing on the subject of the discussed dissertation are published: one into Thomson ISI database; three in other databases; two in international conferences proceedings; one in Lithuanian conference proceeding. 6 presentations on the subject have been given in conferences at national and international level. 


\section{Žymèjimai}

\section{Simboliai}

$A$ - skerspjūvio plotas;

A - pusiausvyros lygčių koeficientų matrica;

b - skerspjūvio plotis;

C - poslinkių funkcijų koeficientų prie polinomų matrica;

D - bendrojo Huko dèsnio pasiduodamumo matrica;

$E$ - tamprumo modulis (Jungo modulis);

F - apkrovos vektorius;

$F$ - išorinè koncentruota jèga;

$f_{u}$ - konstrukcijos medžiagos stiprumo (takumo) riba;

$G$ - konstrukcijos medžiagos šlyties modulis;

$\overline{\mathbf{G}}$ - liekamujų įrąžų infliuentinè matrica;

$h$ - baigtinio elemento skerspjūvio aukštis;

$\mathbf{H}$ - poslinkių darnos matrica;

$\overline{\mathbf{H}}$ - liekamujų poslinkių infliuentinè matrica;

$I$ - skerspjūvio inercijos momentas;

$I_{t}$ - sukimo konstanta;

$\mathbf{K}_{e}-$ mažų poslinkių (tampraus skaičiavimo) standumo matrica;

$\mathbf{K}_{g}$ - geometrinè standumo matrica; 
$\mathbf{K}_{u}$ - pradinių poslinkių standumo matrica;

$\mathbf{K}_{\tau}-$ tangentinè standumo matrica;

$l$ - elemento ilgis;

$\mathbf{L}$ - konstrukcijos elementų ilgių vektorius

$M$ - lenkimo momentas;

$M_{0}$ - ribinis lenkimo momentas;

$N$ - ašinè jèga;

$N_{0}$ - ribinè ašinè jèga;

$\mathbf{P}$ - poslinkių funkcijų koeficientų matrica;

$S$ - kūno paviršius;

S - tikrujų iražǔ vektorius;

$\mathbf{S}_{0}$ - ribinių irą̨žų vektorius;

$\mathbf{S}_{e}$ - tampraus sprendinio ịrąžų vektorius;

$\mathbf{S}_{r}$ - liekamuju ịrąžų vektorius;

$S_{u}-$ kūno paviršiaus dalis, kurioje kūno poslinkiai yra apriboti;

T - krypčių kosinusų matrica;

$T$ - sukimo momentas;

$t$ - skerspjūvio storis;

$u$-poslinkis;

u - poslinkių vektorius;

$U$ - potencinè deformavimo energija;

$V$ - konstrukcijos tūris;

$W_{p l}$ - plastinis atsparumo momentas;

$W_{t}$ - laisvo sukimo atsparumo momentas;

$\gamma_{k}(x)$ - $k$-ojo baigtinio elemento skersine deformacija;

$\gamma$ - koeficientas;

$\Delta$ - linijinè deformacija;

$\varepsilon$-deformacija;

$\boldsymbol{\varepsilon}$ - deformacijų vektorius;

$\theta$ - skersine deformacija;

$\kappa$ - kreivis; 
$\lambda$ - Lagranžo daugiklių vektorius;

$\Pi$ - pilnutinè diskretizuoto kūno potencinè energija;

$\sigma$-itempiai;

$\boldsymbol{\tau}$ - skersiniu įtempių vektorius;

$\tau_{y}$ - takumo įtempis grynosios šlyties metu;

$\varphi$ - kampinè deformacija;

$\boldsymbol{\Phi}$ - konstrukcijos stiprumo (takumo) sąlygų koeficientų matrica;

$\boldsymbol{\Psi}$ - vidiniu jègų vektorius;

$\Omega$ - potencinè išorinių jègų energija (išoriniu jègų potencialas).

\section{Santrumpos}

BEM - baigtinių elementų metodas;

İDB - įtemptas deformuotas būvis. 


\section{Turinys}

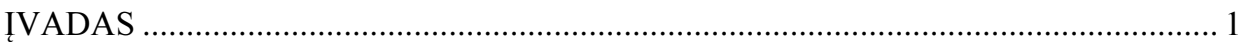

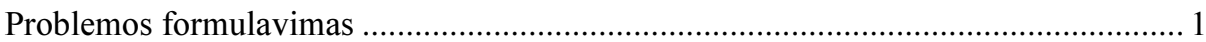

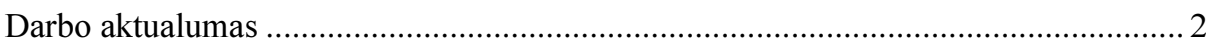

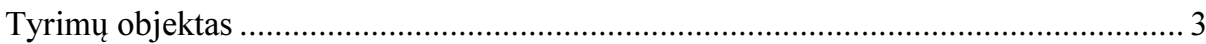

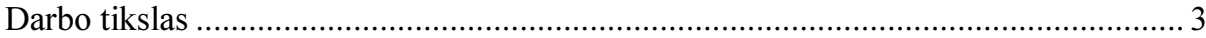

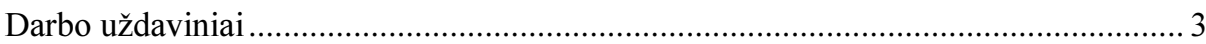

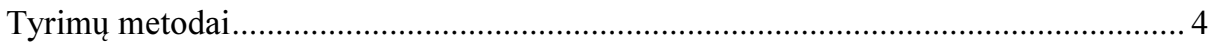

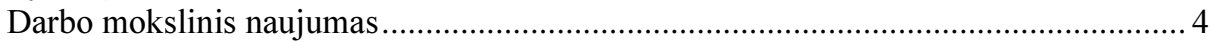

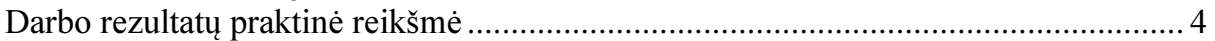

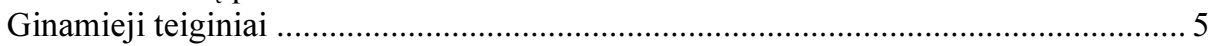

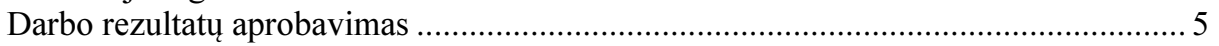

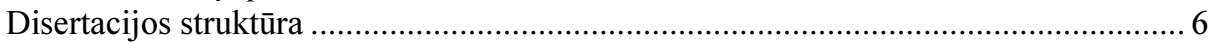

1. KONSTRUKCIJU OPTIMIZAVIMAS VERTINANT KOMPLEKSINIUS

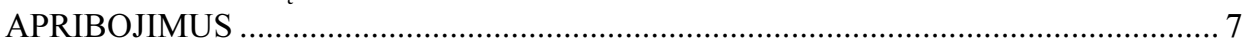

1.1. Projektavimo ir konstrukcijų optimizavimo uždavinių sąsajos .............................. 8

1.2. Optimizavimo metodų istorinè apžvalga............................................................... 9

1.3. Konstrukcijų optimizavimo metodų analitinė apžvalga ....................................... 12

1.4. Netamprių geometriškai netiesinių plieninių rèminių konstrukcijų optimizavimas

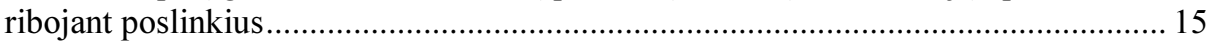

1.5. Pagrindinès prielaidos ir fizinès priklausomybès ................................................ 17

1.6. Pagrindiniai dydžiai, aprašantys konstrukcijos ịtemptą deformuotą būvị ............ 19

1.7. Konstrukcijų optimizavimo uždavinio matematinis modelis ...............................22

1.8. Optimizavimo uždavinių skaitinè realizacija ………........................................ 22

1.9. Pirmojo skyriaus išvados ir disertacijos uždavinių formulavimas ....................... 24

2. GEOMETRIŠKAI NETIESINIŲ KONSTRUKCIJŲ ANALIZĖ …………..............22

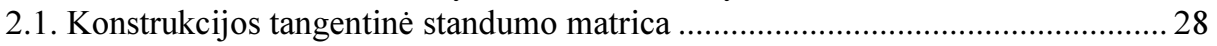

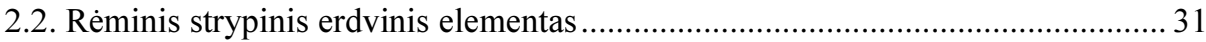

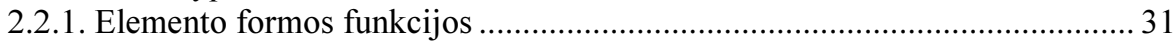


2.2.2. Deformacijų aproksimacija mazginiais poslinkiais ....................................... 38

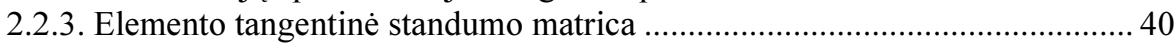

2.2.4. Ekvivalentinių apkrovos jẻgų apskaičiavimas .............................................. 46

2.3. Tangentinio standumo metodo skaitmeninis realizavimas................................... 48

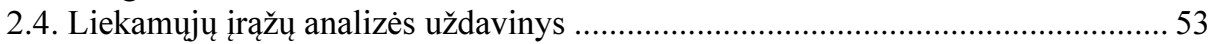

2.5. Liekamujų poslinkių analizès uždavinys......................................................... 55

2.6. Liekamujų poslinkių analizès uždavinys taikant normatyvinius reikalavimus .... 56

2.7. Stiprumo sąlygos sudètingo deformavimosi būviui ............................................57

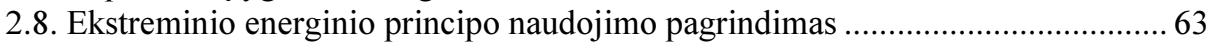

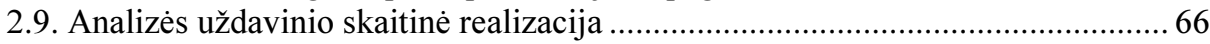

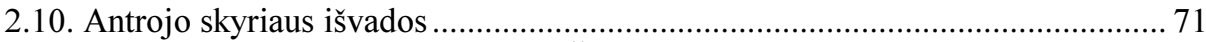

3. KONSTRUKCIJŲ OPTIMIZAVIMO UŽDAVINYS RIBOJANT POSLINKIUS ... 73

3.1. Optimizavimo uždavinio ribojant poslinkius matematinis modelis ..................... 74

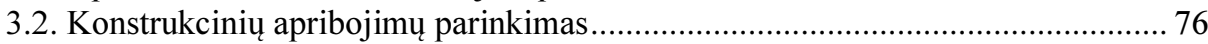

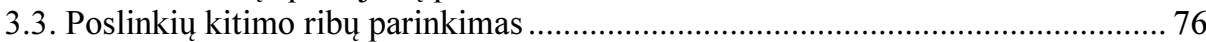

3.4. Optimizavimo uždavinio ribojant poslinkius pradinio taško parinkimas ..............78

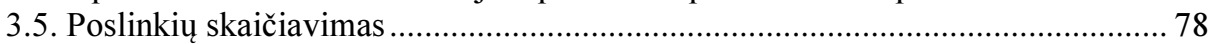

3.6. Optimizavimo uždavinio sprendimo išplèstinis algoritmas ................................ 79

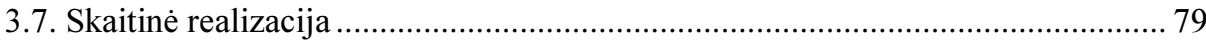

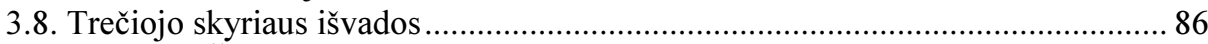

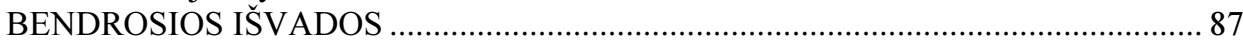

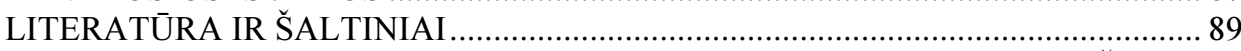

AUTORIAUS MOKSLINIŲ PUBLIKACIJŲ DISERTACIJOS TEMA SĄRAŠAS .... 97

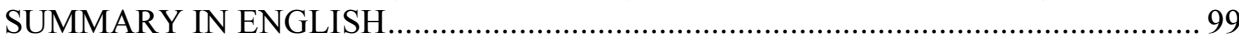

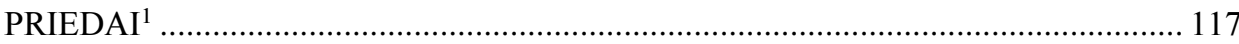

A priedas. Tangentinès standumo matricos nustatymas ........................................... 119

B priedas. Ekvivalentinių apkrovos jègų nustatymas .............................................. 131

C priedas. Dviejų aukštų rèmo analizės rezultatai ................................................... 133

D priedas. Šešiu aukštų rèmo optimizacija plastiškosios suirties etape...................... 162

E priedas. Šešių aukštų rèmo analizès uždavinys ...................................................... 194

F priedas. Šešių aukštų rẻmo optimizacija pagal siūlomą algoritmą ........................... 223

$\mathrm{G}$ priedas. Bendraautorių sutikimai teikti publikacijų medžiagą disertacijoje............ 264

$\mathrm{H}$ priedas. Autoriaus mokslinių publikacijų disertacijos tema kopijos....................... 268

${ }^{1}$ Priedai pateikiami pridètoje kompaktinèje plokštelèje 


\section{Contents}

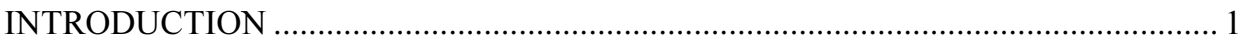

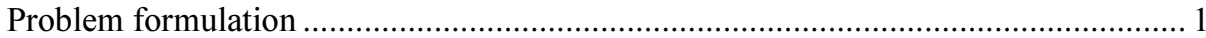

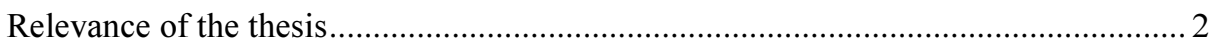

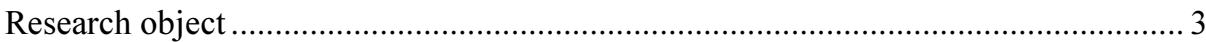

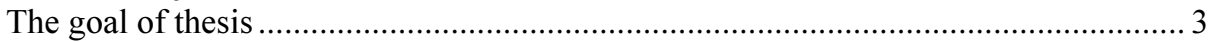

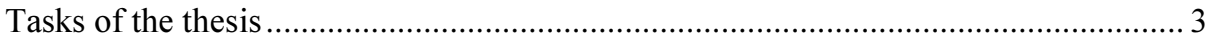

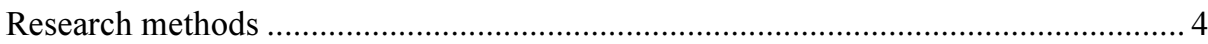

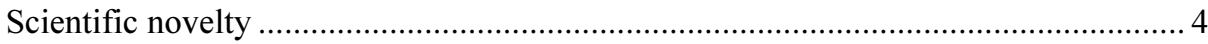

The practical significance of thesis results .................................................................. 4

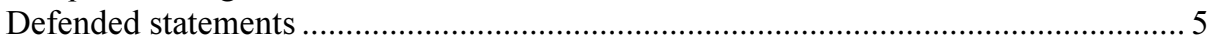

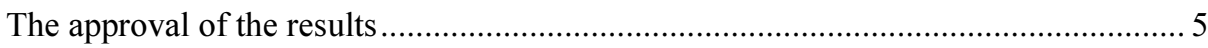

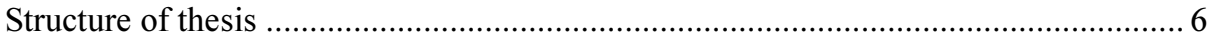

1. THE STRUCTURE OPTIMIZATION UNDER COMPLEX CONSTRAINTS .......... 7

1.1. Design and structure optimization problems relation.......................................... 8

1.2. The historical review of optimization methods .................................................... 9

1.3. The analytical review of structure optimization................................................. 12

1.4. The optimization of inelastic geometrically nonlinear steel frame structures under

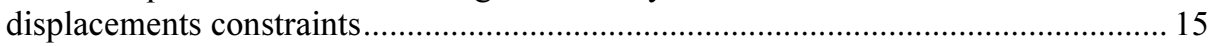

1.5. Basic assumptions and physical dependences .................................................... 17

1.6. Basic values for structure stress-strain state ........................................................ 19

1.7. The mathematical model of structure optimization problem ……………............ 20

1.8. The numerical realization of optimization problem ………................................ 22

1.9. The first chapter conclusions and thesis problems formulation ........................... 24 
2.1. The tangent stiffness matrix of the structure ................................................. 28

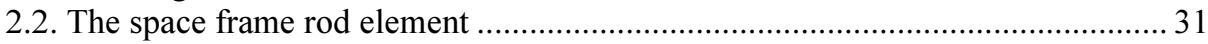

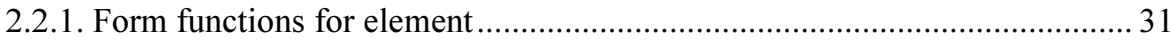

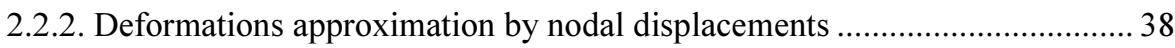

2.2.3. The tangent stiffness matrix of the element .............................................. 40

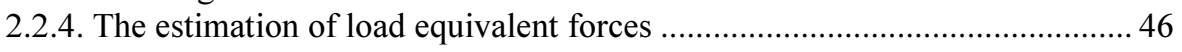

2.3. The numerical realization of the tangent stiffness method ............................... 48

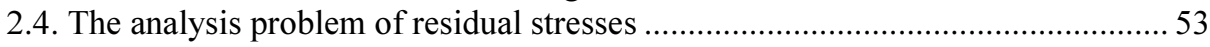

2.5. The analysis problem of residual displacements .......................................... 55

2.6. The analysis problem of residual displacements by applying design code

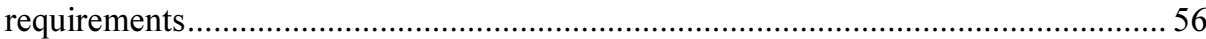

2.7. Strength conditions for combined strain state ............................................... 57

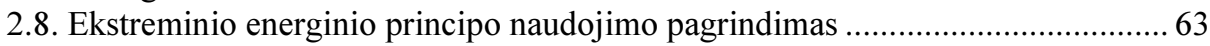

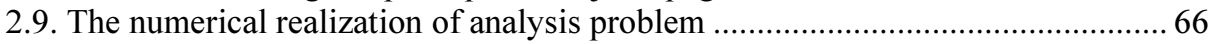

2.10. Second chapter conclusions ....................................................................... 71

3. THE PROBLEM OF STRUCTURE OPTIMIZATION UNDER DISPLACEMENTS

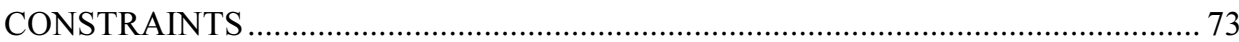

3.1. The mathematical model of optimization problem under displacements

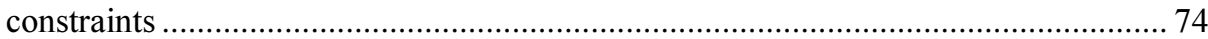

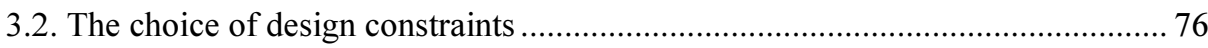

3.3. The choice of constraints for displacements variations .................................. 76

3.4. The choice of start point for optimization problem under displacements

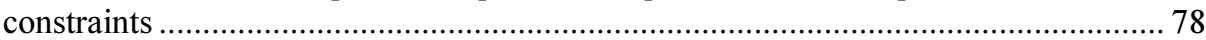

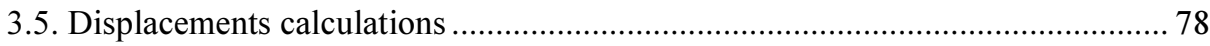

3.6. Optimization problem solution extended algorithm ........................................ 79

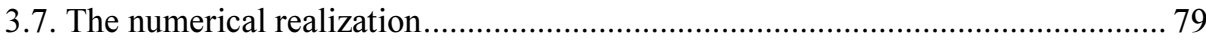

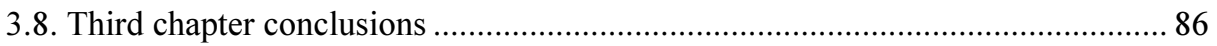

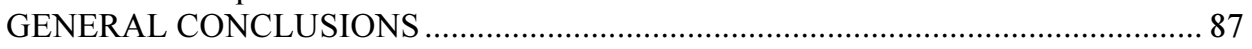

REFERENCES …........................................................................................ 89

THE LIST OF SCIENTIFIC AUTHOR'S PUBLICATIONS ON THE SUBJECT OF THE DISSERTATION ...................................................................................... 97

SUMMARY IN ENGLISH............................................................................. 99

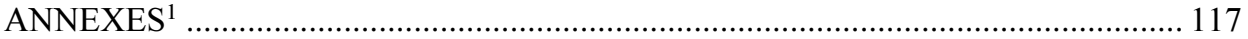

Annex A. The determination of tangent stiffness matrix........................................ 119

Annex B. The determination of equivalent load forces ...................................... 131

Annex C. The analysis of two story frame ....................................................... 133

Annex D. The optimization of six story frame prior to plastic collapse ................... 162

Annex E. The analysis of six story frame ........................................................... 194

Annex F. The optimization of six storey frame by suggesting algorithm ................. 223

Annex G. The co-authors agreement to present publication...................................... 264

Annex H. Copies of author scientific publications on the subject of thesis.............. 268

${ }^{1}$ Annexes are provided in the attached CD-ROM 



\section{Ivadas}

\section{Problemos formulavimas}

Konstrukcijų optimalus projektavimas grindžiamas normatyvinių dokumentų reikalavimais: saugos, tinkamumo bei konstruktyviniais. Statybinių konstrukcijų optimizavimas yra objekto kūrimas, kuris tenkintų projektavimo sąlygų reikalavimus ir atitiktų priimto kokybès kriterijaus geriausią vertę. Konstrukcijų optimizavimas - tai pirmasis etapas optimaliame konstrukcijų projektavime leidžiantis įvertinti aukščiau minètus reikalavimus bei kompleksiškai aprašyti projektuojamos konstrukcijos darbą. Sudarius skirtingas konstrukcijų optimizavimo uždavinių formuluotes bei išsprendus uždavinius galima atsakyti i daugeli projektuotoją dominančių klausimų: koks yra tikrujų įrąžų ir poslinkių pasiskirstymas, kokią apkrovą gali atlaikyti konstrukcija (patikrinamasis uždavinys), kokie turi būti elementų skerspjūvių geometriniai parametrai (projektinis uždavinys), siekiant užtikrinti saugu ir ilgalaikị konstrukcijos darbą.

Šiuolaikinès konstrukciju projektavimo tendencijos susijusios su konstruktyvinių statybinių medžiagų taupymu. Vis daugiau normatyvinių dokumentu nurodo be tradicinio tiesinès teorijos skaičiavimu ivertinti ir konstrukcijos geometrinio netiesiškumo elgsenos aspektus. Tai pavyktu įvertinti tikraji konstrukcijos darbą, atsižvelgiant i plastines medžiagos savybes ir geometrinį konstrukcijos netiesiškumą, esant visoms galimoms darbo sąlygoms 
jos eksploatavimo laikotarpiu. Toks konstrukcijų optimizavimo uždavinys negali būti išspręstas statybinès mechanikos tiesinès teorijos metodais, kadangi konstrukcijos geometrija prie atitinkamų apkrovų iš esmès keičiasi ir mažų poslinkiu principas tampa nepatikimas. Viršijus stiprumo (takumo) ribą, Huko dèsnis daugeliui medžiagų nebegalioja ir keičiamas netiesine įtempių ir deformacijų priklausomybe. Taigi, reikia atsisakyti tiesinès teorijos prielaidu ir pereiti prie žymiai platesnių ir sudètingesnių netiesinès teorijos pritaikymų:

1. Reikia atsisakyti skaičiavimo pagal nedeformuotą būvį, kuris toleruoja mažus poslinkius.

2. Reikia ivertinti konstrukcijos geometrijos pasikeitimo įtaką jos itempių deformacijų būviui (IDB).

3. Pereiti prie netiesinio ịtempių ir deformacijų ryšio, atsižvelgiant i atsirandančias plastines deformacijas (konstrukcijos dar iki plastiškojo suirimo igauna didelius poslinkius ir gali netenkinti normalios eksploatacijos reikalavimų).

4. Parinkti tokias konstrukcijos elementų stiprumo sąlygas, kurios adekvačiai apibrèžtų konstrukcijų darbą. Ivairių šalių normatyviniuose dokumentuose pateiktos ištiesintos stiprumo sąlygos, kurios ženkliai riboja konstrukcijų darbą. Tad tenka naudoti literatūroje ar kitų autorių darbuose pateiktas stiprumo sąlygas, turinčias sąlyginai platesnę stiprumo ribą.

5. Tiksliai vertinti tikrojo IDB poslinkius optimizavimo uždavinio poslinkių ribojimų sudarymui.

Ivertinus visus aukščiau išvardintus aspektus sudaromas matematinis modelis, kurio tiesioginis sprendimas yra gana sudètinga problema. Darbe siūlomas originalus sprendimo algoritmas leidžiantis išvengti sunkumų, kylančių sprendimo metu bei labiau kontroliuoti optimizavimo uždavinio sprendimo procesą.

\section{Darbo aktualumas}

Disertaciniame darbe sudaryti geometriškai netiesinių tamprių plastinių statybinių strypinių konstrukcijų skaičiavimo ir optimizavimo uždavinių matematiniai modeliai, ribojant konstrukcijos poslinkius. Sukurtas geometriškai netiesinių erdvinių strypinių konstrukcijų optimizavimo, ribojant poslinkius, uždavinio sprendimo originalus algoritmas, leidžiantis panaudoti šiuolaikines kompiuterines 
technologijas. Tai statybos inžinerijos praktikoje atveria naujas galimybes taupant medžiagas bei išteklius konstrukcijų projektavimo ir gamybos stadijose.

\section{Tyrimų objektas}

Disertaciniame darbe nagrinèjami geometriškai netiesinių tamprių plastinių strypinių konstrukcijų optimizavimo uždaviniai, ribojant poslinkius, jų matematinių modelių sudarymas ir šių optimizavimo uždavinių sprendimo galimybès.

\section{Darbo tikslas}

Sukurti geometriškai netiesinių tamprių plastinių erdvinių strypinių konstrukcijų optimizavimo uždavinio matematinio modelio, ivvertinančio projektavimo reikalavimus ir sąlygas, sprendimo originalų algoritmą. Šis sukurtas algoritmas leistų kontroliuoti konstrukcijos deformatyvumą iteracinio proceso metu ir užtikrina uždavinio sèkmingą konvergenciją.

\section{Darbo uždaviniai}

Darbo tikslui pasiekti reikia spręsti šiuos uždavinius:

1. Atlikti mokslinès literatūros apžvalgą apie netamprių geometriškai netiesinių plieninių reminių konstrukcijų optimizavimą ribojant poslinkius.

2. Plètoti erdvinio baigtinio elemento tangentinès standumo matricos sudarymo metodiką ir simbolinių skaičiavimu programą šios matricos išraiškai gauti.

3. Sudaryti geometriškai netiesinès tamprios plastinès erdvinès strypinès konstrukcijos analizès uždavinio matematini modeli, išspręsti ṣ̌ uždavinį. Atlikti lyginamają gautų sprendimo rezultatų analizę su kitų tyrèju gautais rezultatais.

4. Sudaryti tamprių plastinių geometriškai netiesinių erdvinių strypinių konstrukcijų, ribojant poslinkius, optimizavimo uždavinio matematinị modelị ir gauti skaitinius šio optimizavimo uždavinio sprendimo rezultatus. Atlikti lyginamają gautų sprendimo rezultatų analizę.

5. Sujungti antros eilès tampraus skaičiavimo, tamprios plastinès konstrukcijos analizès bei optimizavimo, ribojant poslinkius, uždavinius i vieną bendrą iteracinị sprendimo algoritmą. 
6. Naudojant sukurtą programinę įrangą, modeliavimo būdu patikrinti siūlomo optimizavimo uždavinio sprendimo algoritmo veiksmingumą ir efektyvumą.

\section{Tyrimų metodai}

Darbe taikomi skaitinio modeliavimo metodai: baigtinių elementu metodas, Niutono-Rafsono netiesinių lygčių sprendimo metodas, netiesinių optimizavimo uždavinių sprendimo metodai.

\section{Darbo mokslinis naujumas}

Siūlomo originalaus konstrukcijų optimizavimo uždavinio sprendimo algoritmo principai gali būti taikomi skaičiuojant bet kokio tipo konstrukcijas.

Ištirta erdvinio baigtinio elemento tangentinè standumo matricos sudarymo metodika, kuri gali būti taikoma, nustatant kitų baigtinių elementų tipų tangentinių standumo matricu išraiškas. Metodikos principai gali būti panaudoti kuriant simbolinių skaičiavimų programas kitų baigtinių elementų tipų tangentinių matricu išraiškoms gauti.

Sudarytas geometriškai netiesinių tamprių plastinių erdvinių strypinių konstrukcijų analizès uždavinio matematinis modelis bei išspręstas analizės uždavinys, naudojant netiesines stiprumo sąlygas, kuris leidžia nustatyti nagrinejamos konstrukcijos tikraji IDD artimą realios konstrukcijos darbui. Analizès rezultatai buvo palyginti su kitų autorių tirtų realių konstrukcijų bandymų rezultatais.

Suformuluotas ir išspręstas konstrukcijų optimizavimo uždavinys, naudojant netiesines stiprumo ir poslinkių ribojimo sąlygas bei ịvertinant konstrukcijos tikraji IDB.

\section{Darbo rezultatų praktinè reikšmè}

Pasiūlytas geometriškai netiesinių tamprių plastinių plieninių erdvinių strypinių konstrukcijų optimizavimo uždavinio matematinio modelio sprendimo algoritmas, apimantis saugos, tinkamumo ir konstruktyvinius reikalavimus, gali būti taikomas projektuojant arba rekonstruojant realias konstrukcijas. 


\section{Ginamieji teiginiai}

Disertacijos ginamieji teiginiai:

1. Norint, kad skaičiavimas atitiktų realias konstrukcijų darbo sąlygas, visų pirma skaičiuojant reikia atsižvelgti i medžiagu plastines savybes, kuriomis pasižymi ne maža konstrukcijų (ypač metalinių) dalis, bei jų deformuoto būvio geometriškai netiesinę elgseną.

2. Matematinio programavimo teorija ir mechanikos ekstreminiai energiniai principai suteikia galimybę sudaryti naujus geometriškai netiesinių tampriu plastiniu statybiniu strypinių konstrukcijų optimizavimo uždavinių matematinius modelius, ribojant konstrukcijos poslinkius, bei šių uždavinių sprendimo algoritmus ir metodus.

3. Tamprių plastinių geometriškai netiesinių konstrukcijų optimizavimo metodu tobulinimas yra teorinis ir praktinis pagrindas statybiniu konstrukcijų eksperimentinei-mokslinei plètrai: naujos galimybès medžiagų bei išteklių taupymui konstrukcijų projektavimo ir gamybos stadijose.

\section{Darbo rezultatų aprobavimas}

Disertacijos tema yra atspausdinti septyni moksliniai straipsniai: vienas - mokslo žurnale, itrauktame i ISI Web of Science duomenų bazę (Karkauskas, Popov 2011); trys - kituose duomenu bazèse (Popov et al. 2013; Karkauskas, Popov 2009 a; Karkauskas, Popov 2009 b); vienas - recenzuojamoje užsienio tarptautinès konferencijos medžiagoje (Каркаускас and Попов 2007); vienas recenzuojamoje Lietuvos tarptautinès konferencijos medžiagoje (Popov et al. 2010); vienas - nerecenzuojamoje Lietuvos konferencijos medžiagoje (Popov, Karkauskas 2007).

Disertacijoje atliktų tyrimų rezultatai buvo paskelbti septyniose mokslinėse konferencijose Lietuvoje ir užsienyje:

- Jaunujų mokslininkų konferencijoje „Lietuva be mokslo - Lietuva be ateities" $2007 \mathrm{~m}$. Vilniuje;

- Jaunujjų mokslininkų konferencijoje „Mokslas - Lietuvos ateitis“ 2009 m. Vilniuje;

- Jaunujų mokslininkų konferencijoje „Mokslas - Lietuvos ateitis“ 2012 m. Vilniuje;

- Tarptautiniame simpoziume „Проблемы современного бетона $и$ железобетона“ 2007 m. Minske, Baltarusijoje; 
- Tarptautinejje mokslinejje konferencijoje „Modern building materials, structures and techniques" $2010 \mathrm{~m}$. Vilniuje;

- Tarptautinejje mokslinejje konferencijoje „Optimization and Analysis of Structures“" 2011 m. Tartu, Estijoje;

- Tarptautineje konferencijoje „Задачи и методы компьютерного моделирования конструкиий и сооружений“ (,,Золотовские чтения“). 2013 m. Maskvoje, Rusijoje.

\section{Disertacijos struktūra}

Disertaciją sudaro įvadas, trys skyriai ir rezultatų apibendrinimas. Taip pat yra 8 priedai.

Darbo apimtis yra 118 puslapiu, neskaitant priedu, tekste panaudotos 144 numeruotos formulès, 32 paveikslai ir 12 lentelių. Rašant disertaciją buvo panaudoti 104 literatūros šaltiniai. 


\section{Konstrukcijų optimizavimas vertinant kompleksinius apribojimus}

Skyriuje aprašomos konstrukcijų projektavimo ir jų optimizavimo uždavinių sąsajos. Atlikta optimizavimo uždavinių formulavimo ir jų sprendimo metodų analitinè bei trumpa istorinè apžvalga. Démesys sutelktas disertacijos problematikai: netamprių geometriškai netiesinių plieninių rèminių konstrukcijų optimizavimui, ribojant mazgu poslinkius. Aprašomos pagrindinès disertacijoje taikomos prielaidos, fizikinès priklausomybès bei dydžiai, charakterizuojantys konstrukcijos įtempių ir deformacijų būvį (ĮDB). Pateikiamas disertacijos autoriaus sudarytas konstrukcijų optimizavimo uždavinio bendrasis matematinis modelis ir bendrasis algoritmas šio uždavinio skaitinei realizacijai.

Skyriaus tematika yra paskelbti (kartu su bendraautoriais) trys disertanto straipsniai (Popov and Karkauskas 2007; Каркаускас and Попов 2007; Karkauskas and Popov 2009 b). Rezultatai buvo aprobuoti: jaunųju mokslininkų konferencijoje „Mokslas - Lietuvos ateitis“ (2007 m.); tarptautiniame simpoziume „Проблемы современного бетона и железобетона“ (2007m.) Minske, Baltarusijoje; tarptautineje mokslinejje konferencijoje „Optimization and Analysis of Structures" 2011 m. Tartu, Estijoje; Tarptautineje konferencijoje „Задачи и методы компьютерного моделирования конструкций $и$ сооружений“ (,,Золотовские чтения“), 2013 m. Maskvoje, Rusijoje. 


\subsection{Projektavimo ir konstrukcijų optimizavimo uždavinių sąsajos}

Projektavimo uždavinys - tai statinių arba atskirų konstrukcijų, privalančių per nustatytą laikotarpi atlikti tam tikras funkcijas ir būti patikimais juos eksploatuojant, projekto rengimas. Pageidautina, kad statybos, o véliau ir eksploatacijos sąnaudos būtų minimalios. Tradiciniame statybinių konstrukcijų projektavimo procese inžinieriui projektuotojui, remiantis savo patirtimi ir intuityviais samprotavimais, tenka nustatyti daugybę konstrukcijos parametrų. Pavyzdžiui, dèl architektūrinių, funkcinių reikalavimų apibrèžti pradinius laikančiujų konstrukcijų, net elementų skerspjūvių matmenis bei kitus parametrus. Projektavimo normos itakoja galutini projektini sprendimą. Šiuo atveju projektuotojas neišvengiamai nukrypsta nuo optimalaus sprendinio: nukrypimo dydis pirmiausia priklauso nuo jo kvalifikacijos, konstrukcijos sudetingumo, papildomų projektinès užduoties reikalavimų. Kuo sudètingesnè projektuojama konstrukcija, tuo mažesnès intuicijos galimybès optimalaus sprendimo paieškoje. Šiame kontekste mokslo literatūroje (Никитин and Чибиряков 1987; Рейтман and Ярин 1974) pateikiami įdomūs tyrimo rezultatai: dvidešimčiai projektuotojų buvo pasiūlyta pagal vienodus pradinius duomenis atlikti ịvairių gelžbetoninių konstrukcijų projektavimą; rezultatai buvo gana netikèti - nesudètingu konstrukcijų sąnaudų skirtumas siekè 5-7\%, o sudètingų - iki 40\%. Pabrèžtina tai buvo gauta, laikantis visų norminių dokumentų reikalavimų. Šie pavyzdžiai išryškina skirtingą projektuotojų atsargumo lygị bei parodo galimą teorinį resursų sutaupymą, renkantis galutini projektą.

Pastaraisiais metais konstrukcijų projektavime plačiai taikomi kompiuteriniai analizès ir projektavimo metodai, tam talkina naujausios kompiuterinès programos, ivertinančios realias konstrukcijų darbo ir vis sudètingèjančias kraštines sąlygas siekiant projekto kokybès. Plačiai taikomas baigtinių elementų metodas (BEM) yra naudojamas konstrukcijos itempių, poslinkių, svyravimo dažnių ir kitų konstrukcijų projektavimui reikalingų duomenų nustatymui. Dažnai viso projektavimo metu yra naudojami skaitiniai ir net eksperimentiniai tyrimai kuriamo projekto kokybei iqvertinti. Pagal šiuos tyrimus projektas keičiamas ir atliekama jo pakartotinè analizé, stengiantis pagerinti arba bent užtikrinti projektui keliamus reikalavimus. Toks tradicinis statinio projekto analizès ir tikrinimo kelias paprastai imanomas, atsižvelgus tik i vieną-kitą projektą vertinančių kintamujjų (dažniausiai tik į vieną!), bet neįvertina kintamųų visumos tarpusavio sąveikos. Tuo tarpu skaitinè optimizacija leidžia vienu metu ịvertinti didelị projektavimo parametrų, tenkinančių eksploatacinius reikalavimus, skaičių ir tuo pačiu metu gauti geresni projektą.

Skaitinès optimizacijos uždavinio bendroji formuluotė dažniausiai yra tokia: 
Rasti

$$
\begin{gathered}
f(\mathbf{x}) \rightarrow \min , \\
g_{i}(\mathbf{x}) \leq 0, \quad i=1, \ldots, \mathrm{m}, \\
x_{j}^{L} \leq x_{j} \leq x_{j}^{U} \quad j=1, \ldots, \mathrm{n} .
\end{gathered}
$$

kai

Tikslo arba vertès funkcija $f(\mathbf{x})$ priklauso nuo projektavimo kintamujų $\mathbf{x}$, kurie, pavyzdžiui, susideda iš konstrukcijų elementų skerspjūvių ar fizinių parametrų. Apribojimai (1.2) $g_{i}(\mathbf{x})$ užtikrina saugos būvio reikalavimus, tuo tarpu kintamujų ribos, pateiktos (1.3) sąlygose yra vadinamos konstrukciniais apribojimais (dažniausiai naudojami optimalaus sprendinio paieškos srities tikslinimui, neleidžiant, pavyzdžiui, konstrukcijos elemento storiui igyti neigiamas reikšmes). Jei reikia surasti funkcijos $f(\mathbf{x})$ maksimalią reikšmę, pavyzdžiui, nustatyti maksimalų konstrukcijos nuosavą dažnị, tai padaroma minimizuojant neigiamą funkcijos $f(\mathbf{x})$ išraišką.

Dažniausiai paplitę (1.2) apribojimai, kurie riboja ịtempius ịvairiuose konstrukcijos mazguose. Tada, jei $\bar{\sigma}$ yra viršutinè leistino ittempio riba, apribojimo funkcija normalizuota forma gali būti užrašoma taip:

$$
\left(\sigma_{i j k} / \bar{\sigma}\right)-1 \leq 0
$$

čia $i$-strypo numeris; $j$ - itempio komponentas; $k$-apkrovos būvis.

Būtina paminèti, kad optimizavimo uždavinio matematinis modelis (1.1)(1.3) gali būti papildytas apribojimais-lygybèmis:

$$
h_{k}(\mathbf{x})=0, \quad k=1, \ldots, l .
$$

Matematinio programavimo uždavinio (toks yra konstrukcijų optimizavimo uždavinys (1.1)-(1.3)) sprendimo būdai gali būti grindžiami skirtingos kokybès algoritmais, kurie glaustai bus analizuojami kitame poskyryje. Iš karto pažymètina, kad be darbų, kuriuose pristatomi nauji optimizacijos skaičiavimo būdai, algoritmai ir uždaviniai, periodiškai pasirodo ir tokie darbai, kuriuose apžvelgiama konstrukcijų optimizacijos vystymosi istorija (Schoofs 1993; Vanderplaats 1999, 2006).

\subsection{Optimizavimo metodụ istorinè apžvalga}

Optimizavimo teorija ir matematiniai metodai yra neatskiriami. Jų egzistavimas siekia Niutono (Sir Isaac Newton, 1643-1727), Lagranžo (Adrien-Marie Legendre 1752-1833) ir Koši (Augustin Louis Cauchy 1789-1857) laikus. Variantinių skaičiavimų pagrindą padejjo Bernulis (Jacob Bernoulli 1654-1705), Euleris (Leonhard Euler 1707-1783), Lagranžas (Adrien-Marie Legendre 17521833) ir Vejerstrasas (Karl Theodor Wilhelm Weierstraß 1815-1897). Koši 
(Augustin Louis Cauchy 1789-1857) pirmasis pritaikè greičiausio nusileidimo metodą besąlyginių minimizacijos uždavinių sprendimui. Laikoma, kad konstrukcijų optimizavimo istorijos pradžia sietina su XIX amžiaus antraja puse (minètini (Levi 1874) ir (Mitchell 1904) darbai). Nepaisant šių ankstyvujų darbų iki pat XX amžiaus vidurio pažanga konstrukcijų optimizavimo srityje buvo labai maža. Tik vèliau, pradejus sparčiai vystytis kompiuterinėms technologijoms, optimizavimo procedūru ịgyvendinimas tapo įmanomas ir tai paskatino tolesnius naujų metodų mokslinius tyrimus.

Manoma, kad šiuolaikinio optimizavimo, grindžiamo kompiuterinèmis technologijomis, pradžia sietina su klasikiniu tapusiu Šmito darbu (Schmit 1960). Šmitas savo publikacijose minejo Kleino (Klein 1955) darbą, iš kurio jis pasisèmęs pagrindinių idejų. Konstrukcijų optimizavimo raida neatsiejama nuo bendrujų optimizavimo algoritmų pletojimo. Bendroji optimizacija sukuria faktinius optimizavimo algoritmus, o konstrukcijų optimizavimas siūlo pažangius metodus efektyviam šių algoritmų panaudojimui. Tad prieš apžvelgiant konstrukcijų optimizacijos istorinę raidą, pateikiama optimizavimo algoritmų vystymosi raida.

Atsitiktinès paieškos metodai buvo labai populiarūs šeštajame bei septintajame praejusio amžiaus dešimtmetyje. Šiuose metoduose, atsitiktinai parinkus nežinomųjų vektoriaus reikšmes, buvo atliekama uždavinio analizè ir jei buvo nustatoma, kad kažkuris projektas yra geresnis, jo ir buvo laikomasi. Toks skaičiavimas buvo atliekamas tol, kol nebesikeisdavo sprendimo rezultatai arba kol būdavo išnaudojami visi kompiuteriniai resursai (kas buvo ịprasta tais laikais). Pasirenkamais dydžiais galèjo būti faktinès nežinomujų reikšmès arba tų reikšmių pokyčiai. Kai kurie mokslininkai pastebejjo, kad po tam tikro laiko jie gali gauti projekto nežinomujų reikšmių vektorių seką nuo blogiausio iki geriausio bei paspartinti šios sekos gavimo procesą. Tai galima pavadinti labai primityvia supaprastinta gradientine rezultatų paieška. Šie skaičiavimo metodai buvo lengvai programuojami, bet labai neefektyvūs ir apsiribodavo tik keliais kintamaisiais.

Nuo 1960 metų mokslininkų dèmesys buvo skirtas nuosekliam tiesiniam programavimui (angl. Sequential Linear Programming arba SLP) (Kelly 1960), nuoseklioms besąlyginio minimizavimo technikoms (angl. Sequential Unconstrained Minimization Techniques arba SUMT) (Fiacco and McCormick 1968) bei galimų krypčių metodams (angl. Feasible Directions methods) (Zoutendijk 1960). Nors tuo metu lygiagrečiai buvo kuriami ir negradientiniai metodai, tačiau paminetieji, gradientais paremti metodai, buvo laikomi efektyvesniais ir patikimesniais.

1970-aisiais metais buvo plètojami Lagranžo daugiklių (angl. Augmented Lagrange Multiplier) (Rockefellar 1973) bei apibendrintasis redukuoto gradiento (angl. Generalized Reduced Gradient) (Gabriel and Ragsdell 1977) metodai. Šių metodų pranašumas buvo stiprus jų teorinis pagrindas - Kuno ir Takerio (Kuhn- 
Tucker) optimalumo sąlygos. Kuno ir Takerio pagrindinè idejja buvo sukurti efektyvų ir patikimą algoritmą, užtikrinantị balno taško (1.1 pav.) radimą. 1970ujų metu pabaigoje buvo pradèti plètoti paviršiaus atsako (angl. Response Surface) metodai (Vanderplaats 1979; Myers et al. 2009), kurie yra vystomi ir dabartiniu metu.

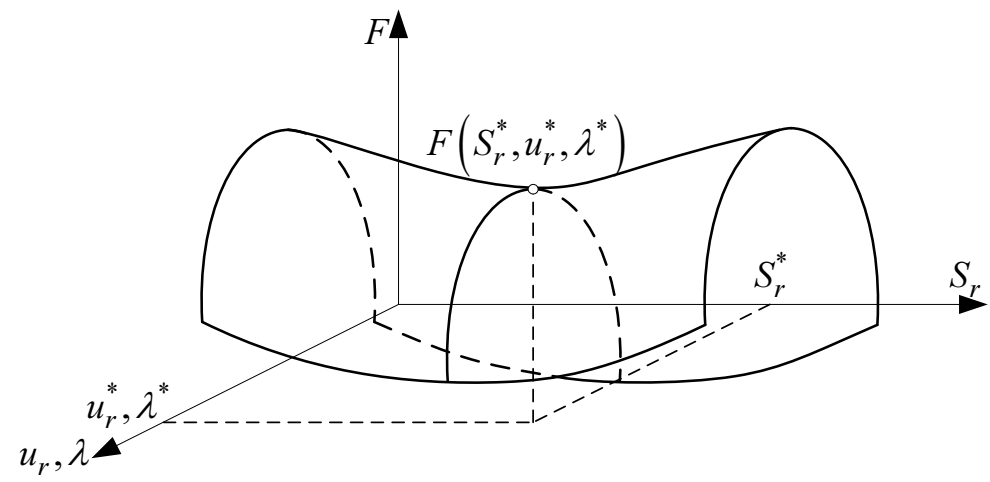

1.1 pav. Balno funkcijos Kuno ir Takerio taškas

Fig. 1.1. Kuhn-Tucker point of the saddle function

1980 metų pradžia buvo optimizavimo algoritmų tikslinimo užbaigimo bei inžinerinèje bendruomenèje atsinaujinusio dèmesio atsitiktiniams metodams ir nuoseklioms besąlyginio minimizavimo technikoms (angl. Sequential Unconstrained Minimization Techniques arba SUMT) laikotarpis. Atsitiktiniai metodai apèmé genetinès paieškos (angl. Genetic Search) (Hajela 1990), imitacinio grūdinimo (angl. Simulated Annealing) (Nemhauser and Wolsey 1988) ir kitus susijusius metodus, kurie bande imituoti gamtos evoliucijos procesus. Nuoseklios besąlyginio minimizavimo technologijos susitelkè ties vidinio taško metodais, grindžiamais Kuno ir Takerio (Kuhn-Tucker) sąlygomis (Hager et al. 1994). Genetiniai paieškos algoritmai 1990-aisiais metais buvo daugelio inžinerinès bendruomenès tyrimų dèmesio centre ir buvo papildyti nauju dalelių telkimosi (angl. Particle Swarming) metodu (Venter and Sobieszczanski-Sobieski 2003). Tuo tarpu mokslininkai, vykdę operacijų tyrimų tobulinimą, susikoncentravo ties vidinio taško metodais ir toliau pastaruosius tobulino. Inžinerinių uždavinių sprendimui buvo sukurtas išorinės baudos funkcijos (angl. Exterior Penalty Function) metodas, sprendžiantis labai didelio masto tolydžių ir diskrečių kintamujų uždavinius (Vanderplaats 2004).

Optimizavimo algoritmams tobulèjant, jų inžinerinio taikymo apimtis ir sudètingumas išaugo (nuo 1960-ųjų metų tai eksponentiškai bei pastoviai didèja). 


\subsection{Konstrukcijų optimizavimo metodų analitinè apžvalga}

Dantzigo (Dantzig 1949) išvystytos tiesinio programavimo technologijos kartu su kompiuterinių technologijų atsiradimu leido panaudoti matematini programavimą strypo ir rèminių konstrukcijų plastiniame projektavime (Heyman 1956). Intensyvi konstrukcijų optimizacija prasidejo su anksčiau minèto darbo (Schmit 1960) paskelbimu. Tai buvo skaitinių sprendimo metodų paieškos laikotarpio pradžia. Šie metodai buvo bendresni nei anksčiau naudotieji, pagristi analitika (Shanley 1952). Šmitas buvo pirmasis, pateikęs išsamią matematinio programavimo technologijų panaudojimo galimybių ataskaitą: kaip išspręsti netiesiškai apribotą, netiesini tamprių konstrukcijų projektavimo uždavinį, esant daugialypėms apkrovimo sąlygoms. Šmitas, norèdamas sukurti naują konstrukcijų sintezès uždavinių sprendimo technologiją, sujungè skaitinę optimizaciją, pagrịstą baigtinių elementų taikymu (išryškejjo galimybe rasti minimalaus svorio konstrukciją).

Šmitas nustate, kad baigtinių elementų metodo taikymas projektavimo uždavinio užrašymui iš tikruju yra tai, ko reikètų, norint rasti minimalaus svorio konstrukciją. Svarbu ir tai, kad nustatinejjant konstrukcijos mazgu poslinkius baigtinių elementu metodas tapo natūraliu įrankiu. Tai buvo galima padaryti naudojant žinomą lygčių sistemą:

$$
\mathbf{K u}=\mathbf{P} .
$$

Elementų įtempiai (irąžos) nustatomi, panaudojus apskaičiuotus poslinkius. Šmitas išsprende minimalaus svorio konstrukcijos nustatymo uždavinį, dabar jau klasika tapusiai trijų strypų santvarai. Šis novatoriškas darbas inicijavo daugybę tyrimų septintajame praeito šimtmečio dešimtmetyje, dalis jų tęsiama ir dabar. Netrukus buvo nustatyta, kad gradientais pagristi optimizavimo metodai yra labiau efektyvūs sprendžiant matematinio programavimo, o tai reiškia, kad ir konstrukcijų optimizacijos uždavinius. Poslinkių ir ịtempių dydžiai buvo nustatomi baigtiniu skirtumu, nes (1.6) lygtis poslinkiams nustatyti reikalauja naujo sprendimo: kaip neišreikštinè funkcija priklauso nuo projektavimo kintamujų (kaip taisyklè, ittakojančių standumo matricą K). Foksas savo darbe (Fox 1965) pažymèjo ši neišreikštini santyki, kaip baigtinių skirtumų dydžių pagrindimą. Iš esmès tai buvo lygties (1.6) diferencijuojamumo klausimas. Nuo to laikotarpio İDB dydžiai buvo apskaičiuojami analitiškai naudojant įvairius metodus (Haug et al. 1986), nepagristai ignoruojant citavimo prasme prioritetinius Fox darbus.

Likusiais minètojo septintojo dešimtmečio metais buvo vykdomi intensyvūs, bet be praktinio pritaikymo konstrukcijų optimizavimo tyrimai. Iš tikrujų šio dešimtmečio pabaigoje tapo akivaizdu, kad optimizavimo uždaviniai yra stipriai 
apriboti jų skaitinès realizacijos prasme - nežinomujų skaičius siekdavo vos penkiasdešimt, ir net tokiuose uždaviniuose realių konstrukcijų diskretiniams modeliams sudaryti buvo būtina pasitelkti daugiau nei šimtą baigtinių elementų. Atsižvelgiant i tuometinius kompiuterių pajègumus, augant konstrukcijų diskretinių modelių kokybei (daugèja baigtinių elementų!), buvo aišku, kad konstrukcijų optimizavimas yra aklavieteje ir jos, kaip projektavimo įrankio, naudojimas yra labai brangus. Susiklosčiusi situacija vaizdžiai aprašyta darbe Gallatly et al. (1971), kuriame septintasis dešimtmetis yra pavadintas konstrukcijų optimizavimo ,triumfo ir tragedijos periodu“.

Aštuntajame dešimtmetyje pradèta diskretizuoto optimalumo kriterijų metodų plètra. Venkayya (1971) darbe, vadovaudamasis ankstesniu analitiniu (Prager and Taylor 1968) veikalu, pasiūlè efektyvų metodą uždaviniams su dideliu projektavimo kintamujų skaičiumi spręsti. Glaustai tariant: optimalumo kriterijaus metodai yra efektyvūs, sprendžiant didelès apimties uždavinius, tačiau tik esant ribotam apribojimų, naudojamų sprendimo proceso metu, skaičiui.

Matematinio programavimo panaudojimui konstrukcijų optimizavimo srityje naujas impulsas buvo suteiktas 1974 metais, kai buvo paskelbtas (Schmit and Farshi 1974) darbas, kuriame buvo pateikta konstrukcijų sintezės aproksimacijos technologijų koncepcija. Ši koncepcija buvo patikslinta ir aprašyta gerokai plačiau (Schmit and Miura 1976). Šie metodai buvo grindžiami aproksimacijos kūrimo koncepcija naudojant fizikini pagrindimą - tai leido daryti didelius skaičiavimų žingsnius ir labai sumažinti neišvengiamų detalių baigtinių elementų lygčių perskaičiavimų skaičių (maždaug nuo 100 iki 10). Buvo ịrodyta, kad šios aproksimacijos tiksliai išlaiko ịtempių ir poslinkių apribojimus statiškai išsprendžiamoms santvaroms ir kevalo konstrukcijoms. Lygiagrečiai aproksimacijos koncepcijai buvo sukurtas susijusių lygybių metodas gradiento apskaičiavimui (Arora and Haug 1979).

Darbe (Fleury and Sanders 1977) buvo pastebètas tiesioginis ryšys tarp optimalumo kriterijų metodų (Venkayya 1971) ir matematinio programavimo, pabrežiant, kad optimalumo kriterijai gali būti nagrinejjami pasitelkus matematinio programavimo dualumo teoriją. Be to prieš tai minètų autorių darbe dar buvo pagrįsta aproksimacijos koncepcija kaip įrankis dideliems uždaviniams nagrinèti - skaitine optimizacija tapo įmanoma spręsti gana didelius projektavimo uždavinius, kartu išlaikant metodui būdingą bendrumą.

Devintajame dešimtmetyje plètojami konstrukcijų optimizavimo metodai, algoritmai . Šio dešimtmečio pradžioje susiklosčiusi situacija pateikta (Schmit 1981; Ashley 1982; Vanderplaats 1982) darbuose. Antroji aproksimacijų karta buvo sukurta, naudojant jègų aproksimacijas (Bofang and Zhanmei 1981; Vanderplaats and Selajegheh 1989) vietoje ankstesnių įtempių aproksimacijų. Šios aproksimacijos praplèté kevalų, strypų ir daugelio kitų elementų optimizavimo galimybes. Svarbu pažymèti, kad tuo metu tokiose sistemose kaip 
rèmai buvo įmanoma nagrinèti fizikinius matmenis kaip projektavimo kintamuosius, o skerspjūvių savybes - kaip tarpinius kintamuosius.

1960 metais buvo pradèti nagrinèti konstrukcijos formos (topologijos) optimizavimo uždaviniai. Čia buvo taikomi ir genetiniai algoritmai (Hayalioglu 2000; Rajan, Nguyen 2004; Sarma, Adeli 2000; Kim and Kwak, 2002), pagrịsti biologinių atrankos principų panaudojimu konstrukcijų optimizavimo realizacijos kompiuterinèse technologijose. Taip išvengiama projektuotojų nemėgstamų funkcijų išvestinių, kurios labai plačiai taikomos klasikiniuose konstrukcijų optimizavimo metoduose.

Konstrukcijų optimizavimo tema ir toliau išlieka aktuali, apie tai galima spręsti pagal dideli publikacijų šia tematika skaičių. Plètojama ne tik konstrukcijų optimizavimo teorija, metodai ir skaičiavimo algoritmai, bet ir jų integracija su šiuolaikinèmis kompiuterinio modeliavimo ir automatizuoto projektavimo sistemomis (Atkočiūnas et al. 2008, Kaveh and Talatahari, 2010; Aydoğdu and Saka 2012, Doğan and Saka 2012; Hasançebi and Kazemzadeh Azad 2012).

Šiuolaikinius statybinių konstrukcijų optimizavimo metodus pagal jų sudètingumą sąlyginai galima suskirstyti i tris lygius (Пермяков et al. 2008). Pirmajam lygiui priskiriamas variantinis projektavimas, numatantis kelius galimu būsimos konstrukcijos variantų nagrinèjimui bei gautų rezultatų palyginimą pagal tam tikrą konstrukcijos kokybę nustatantį kriterijų (dažniausiai pagal techniniusekonominius rodiklius). Statinis skaičiavimas paprastai yra pirminis, nes konstruktyviai preliminariai nustatyti parametrai yra tikrinami pagal jų atitikimą nustatytiems reikalavimams, esant nustatytoms apkrovoms ir poveikiams. Techninių-ekonominių rodiklių palyginimas grindžiamas konstrukcijų tūrio (masès), jų gamybos ir montavimo sudètingumo bei kainų tyrimu. Pagrindinis variantu palyginimo metodo trūkumas, yra tai, kad geriausiu galimu sprendiniu pasirenkamas vienas iš nagrinètų variantų, kai tuo tarpu optimalus variantas gali likti nenagrinètas.

Antrasis lygis - optimizavimas automatizuoto projektavimo rèmuose. Čia naudojamas statinis skaičiavimas, kuris yra atliekamas, pasitelkus konstrukciju analizès kompiuterines technologijas su konstravimo blokų papildymais ir geometrinių bei fizinių parametrų variavimu. Naudojami algoritmai ir skaičiavimo programos grindžiami ịvairiais optimizavimo metodais, pradedant nuo variantų palyginimo ir baigiant griežtu optimizavimo uždavinių matematiniu aprašymu. Kompiuterinių technologijų taikymas leidžia atsisakyti „rankiniam“ skaičiavimui charakteringų supaprastinimų, skaičiavimo schemų parinkimo, sąveikaujant atskiriems elementams ir kitų suvaržymų. Šiuo metu didžioji dalis praktikoje taikomų konstrukcijų optimizavimo uždavinių priklauso antrajam lygiui. Tai liudija, kad daugelis šiuolaikinių darbų šioje srityje orientuoti ị lokalių uždavinių sprendimą (statinị skaičiavimą, elementų skerspjūvių pasirinkimą, mazgų ir jungčių skaičiavimą bei konstravimą, konstrukcijos dydžių unifikavimą 
ir kt.) be gaunamų rezultatų ir realių projektavimo sąlygų tarpusavio įtakos ivertinimo.

Trečiasis optimizavimo lygis grindžiamas projektuojamos konstrukcijos teorine kokybès funkcijos analize. Geriausios (dažniausiai tai - racionaliausios) konstrukcijos bei jos parametrų pasirinkimo uždavinys sprendžiamas, atsižvelgiant i veikiančias apkrovas, skaičiavimo teorijos fizikinių prielaidų, medžiagų stiprumo sąlygų, standumo ir konstruktyvinius reikalavimus. Visų šių faktorių apjungimas viename uždavinyje bei jo nežinomųjų paieškos susiejimas su pasirinkto kriterijaus ekstremalia reikšme leidžia kuo detaliau aprašyti projektavimo procesą ir gauti rezultatą, artimą geriausiam konstrukcijos projekto sprendiniui.

Dideli indèli i tamprių plastinių konstrukcijų optimizavimą matematinio programavimo metodais įneše akademikas Aleksandras Čyras bei jo mokiniai A. Čižas, J. Atkočiūnas, R. Karkauskas, S. Kalanta ir kiti (Atkočiūnas 1994; Čyras et al. 2004; Kalanta 2007; Atkočiūnas and Čižas 2009; Atkočiūnas and Karkauskas 2010; Atkočiūnas 2011). Atliktų tyrimų rezultatai buvo skelbiami ir žinomi užsienyje (Čyras 1983; Каркаускас et al. 1990), o darbas (Karkauskas et al. 1995) buvo ịvertintas Lietuvos valstybine mokslo premija. Šiuose darbuose išvystyta lenkiamų sistemų projektavimo metodika, pagrịsta ekstreminiu energiniu principu apie potencinès energijos minimumą ir išorinių jègų papildomo darbo maksimumą. Sprendimo metu vertinami plastinių deformacijų vystymasis, konstrukcijos standumo sąlygos, pradiniai įtempiai.

\subsection{Netampriụ geometriškai netiesinių plieninių rèminių konstrukcijų optimizavimas ribojant poslinkius}

Konstrukcijos optimizavimo uždavinio pagrindinis tikslas - konstrukcijos projektas, tenkinantis ribinius saugos ir tinkamumo būvių reikalavimus nuo ìvairių išorinių poveikių. Tai galima užtikrinti tik turint išsamią informaciją apie konstrukcijos elgseną esant visoms galimoms darbo sąlygoms bet kuriuo jos egzistavimo laikotarpiu. Suprantama, kad tokia plačia apimtimi šis uždavinys, vadovaujantis statybinès mechanikos tiesinès teorijos metodais, negali būti išspręstas, nes konstrukcijos forma ir matmenys prie atitinkamų apkrovų iš esmès keičiasi dèl ko mažų poslinkių principas tampa nepatikimas. Be to, pradedant nuo tam tikro ịtempių būvio lygio, Huko dèsnis daugeliui medžiagų yra netenkinamas ir keičiamas netiesiniu ryšiu. Vadinasi, reikia atsisakyti tiesinès teorijos prielaidų ir pereiti prie gerokai platesnių ir sudètingesnių netiesinès teorijos apibendrinimų. Visu pirma reikia atsisakyti skaičiavimo pagal nedeformuotą būvị, kurị toleruoja maži poslinkiai. Antra, reikia ịvertinti konstrukcijos geometrijos pasikeitimo įtaką 
jos ịtempių ir deformacijų būviui. Trečia, pereiti prie netiesinio ịtempių ir deformacijų tarpusavio ryšio ir įvertinti atsirandančias plastines deformacijas. Pastarujų vaidmuo kai kurių konstrukcinių medžiagų elgsenoje dar iki konstrukcijos plastiškojo suirimo yra didelis: konstrukcija igauna labai didelius poslinkius ir gali netenkinti normalios eksploatacijos reikalavimų. Naujausieji normatyviniai dokumentai, reglamentuojantys statybinių konstrukciju projektavimą (Eurocode 3 2006, STR 2.05.08:2005, ANSI/AISC 360-10), vis dažniau įtraukia įvairius netiesinius skaičiavimus. Kaip pavyzdi galima paminèti tai, kad sąvokos „plastinis lankstas“ ar „plastinis darbas“ vis dažniau sutinkamos ne tik teoriniuose vadoveliuose (Икрин, В. A. 2005, Li, G.-Q. et al. 2007), bet ir normatyvinę dokumentaciją aiškinančioje literatūroje (Brockenbrough, Merritt 2006, Trahair, N. S. et al. 2008, Wong 2009). Taigi šios minètos priežastys turi būti ịvertinamos, sudarant konstrukcijų optimizavimo uždavinių matematinius modelius.

Atliktų darbų analizè leidžia teigti, kad konstrukcijų optimizavimo metodika, kurioje vienu metu taikoma matematinio programavimo teorija, ekstreminiai energiniai principai ir naudojamos medžiagos netampriosios savybès yra viena iš efektyviausiu (Čyras et al. 2004; Čyras 1983; Kalanta 1997; Karkauskas 1997, 1998; Merkevičiūtè and Atkočiūnas 2003). Čia medžiagos plastiškujų savybių ịvertinimas daug tiksliau parodo konstrukcijos darbą esant įvairiems apkrovimo etapams ir leidžia sukurti gerokai racionalesni projektą (Atkočiūnas et al. 2008; Chen et al. 1999; Čyras et al. 2004; Kalanta 1997; Karkauskas 1997, 1998, 2004; Merkevičiūtė and Atkočiūnas 2003; Saka and Kameshki 1998; Soh and Chan 2001; Zhang and Lu 1995). Verta pabrèžti, kad dauguma atliktų darbų yra pagrįsti ribinès pusiausvyros teorijos prielaidomis (Chen et al. 1999; Čyras et al. 2004; Čyras 1983; Soh and Chan 2001; Zhang and Lu 1995). Dèl šios priežasties gauti optimalūs konstrukcijų projektai patenkina tik stiprumo kriterijus, tenkinančius saugos būvị. Būtina pažymèti, kad optimizavimo rezultatai pagal plastiškojo suirimo kriterijų ne visuomet yra lemiami, nes optimalios konstrukcijos ribinis tinkamumo būvis dèl per didelių netampriujų deformacijų ir jas lydinčių poslinkių atsiradimo gali būti prarastas net ir nepasiekus plastiškos suirties. Be to, optimizavimo uždavinio apribojimų sąlygos dažniausiai yra formuluojamos, neatsižvelgiant i normatyvinès dokumentacijos (Eurocode 3 2006, STR 2.05.08:2005, ANSI/AISC 360-10) reikalavimus ir dèl to optimalios konstrukcijos standumas neužtikrina normalaus jos funkcionavimo. Šios priežastys riboja ribinès pusiausvyros teorijos praktini taikymą, rengiant optimalius konstrukcijų projektus. Todèl konstrukcijos deformuoto būvio parametrų ịvertinimas yra būtinas optimizavimo uždavinių matematiniuose modeliuose. Deformatyvumo apribojimai nusako rèmo mazgų ar atskirų dalių poslinkių ribas, konstrukciniai - minimalius skerspjūvių parametrus, strypų ribinius liaunius bei kitus rodiklius. Nèra abejonių, kad šiandien vienas 
svarbiausių optimalaus projektavimo uždaviniu yra konstrukcijos optimizavimas, ivertinant visus šiuos reikalavimus ir plieno netampriąsias savybes. Todèl disertacijos orientacija i minètų faktorių ịvertinimą, optimizuojant statybines konstrukcijas šiuo metu yra itin aktualus tiek moksline, tiek eksperimentinès plètros prasme.

Realizuojant tokią gana sudètingą matematinio programavimo problemą, kaip optimizavimo uždaviniai su stiprumo ir standumo apribojimais, tenka spręsti neiškilius, netiesinius matematinio programavimo uždavinius. Tai dažniausiai ir nulemia varginanti neiškilių optimizavimo uždavinių praktinio pritaikymo nagrinejjamą, nes šiuo metu matematinio programavimo teorija neturi pakankamai efektyvių ir skaičiavimo prasme patikimų algoritmų, skirtų netiesinių ir neiškilų problemų sprendimui. Tokių uždavinių skaitmeninè realizacija didžiaja dalimi priklauso nuo jų formuluočių specifinių savybių. Egzistuoja keletas galimų kelių jų formulavimui ir sprendimui. Visų pirma galima išskirti ịvairius kombinatorinius bei kryptingo perrinkimo metodus, pavyzdžiui, šakų ir ribų metodą (Baušys and Karkauskas 1987); antra - metodus, pagrịstus sprendinio optimalumo kriterijais, kurie, žvelgiant iš matematinio programavimo pozicijų, yra ekvivalentiški iškilo netiesinio programavimo uždavinių Kuno ir Takerio optimalumo sąlygoms (Saka and Hayalioglu 1991). Šakų ir ribų metodo konvergavimas yra teigiamas algoritmo bruožas. Neigiamas - tenka spręsti daugybę tiesinio programavimo uždavinių, kurių skaičius katastrofiškai išauga sudètingos konstrukcijos atveju. Tokiu būdu šis metodas turi daugiau teorinę nei praktinę taikomają vertę.

Metodai, pagristi Kuno ir Takerio optimalumo sąlygomis, priskiriami netiesioginès optimizacijos metodų grupei. Čia Lagranžo daugiklių metodo pagrindu formaliu matematiniu keliu yra sudaromas Lagranžo funkcionalas pradiniam konstrukcijos optimizavimo uždaviniui. Sudaryto Lagranžo funkcionalo stacionarumo sąlygos yra būtinos apribojimų sąlygos, kurias turi tenkinti optimalus konstrukcijos projektas. Šių sąlygų panaudojimas optimizavimo algoritme yra suvedamas ị tam tikrą iteracinę procedūrą.

Atliktų darbų analizé parodè konstrukcijų optimizavimo uždavinio matematinio modelio skaičiavimo algoritmo, grindžiamo ekstreminiais energiniais principais (Čyras et al. 2004; Čyras 1983; Karkauskas 2007) perspektyvumą ir poreiki ji tobulinti, vertinant konstrukcijų geometriškai netiesini darbą bei atliekant konstrukcijų analizę naudojant ịvairias stiprumo sąlygas. Kaip minèta anksčiau, disertacija orientuota ị kompleksinị šių problemų sprendimą.

\subsection{Pagrindinès prielaidos ir fizinès priklausomybès}

Sudarant konstrukcijos skaičiavimo uždavinių matematinius modelius, paprastai laikomasi tam tikrų geometrinio ir fizikinio pobūdžio prielaidų. Iš vienos pusès 
skaičiavimo teorija turi būti paprasta ir pritaikoma praktiškai, o kita vertus ji privalo kaip i̇manoma tiksliau atspindèti konstrukcijos, pagamintos iš realių medžiagų, būvị. Realybejje šių dvieju sąlygu vienu metu tinkamai ịvykdyti neįmanoma, todèl reikalinga tam tikra konstrukcijos idealizacija. Disertaciniame darbe laikoma, kad:

1. Konstrukcijos medžiaga - idealiai tampriai plastiška, izotropinè. Tokios medžiagos ryšys tarp ịtempių $\sigma$ ir deformacijų $\varepsilon$, apibrěžiamas diagrama, pavaizduota 1.2 paveiksle. Pagal šią schemą tamprioji plastiškoji medžiaga apibūdinama tamprumo moduliu $E$ (tai atitinka pasvirusios diagramos dalies krypties tangentą $E=\tan \alpha$ ) ir takumo riba $f_{u}$. Medžiagos sustiprèjimo ir valkšnumo itaka disertaciniame darbe neįvertinama. Kaip žinoma, idealus plastiškumas yra pirmasis priartejjimas prie realaus konstrukcijos darbo už tamprumo ribos, o pagal ją suformuluoti metodai, tinka, kai ribinè konstrukcijos būsena yra visiškas stiprumo išnaudojimas.

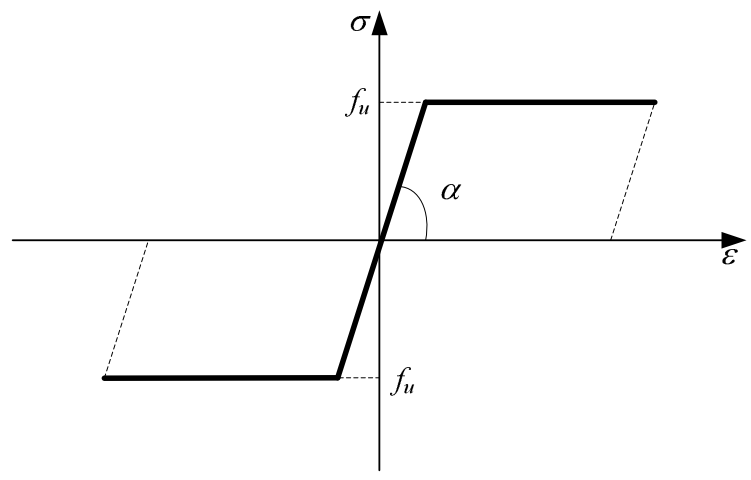

1.2 pav. Idealiai tamprios plastinès medžiagos diagrama

Fig. 1.2. Ideally elastic plastic material diagram

2. Apkrovos pridejjimas - vienkartinis procesas, apkrova kvazistatinè, t. y. tariama, kad laikui bègant išorinès apkrovos kitimo greitis pakankamai mažas (apkrova nepriklauso dinaminiam tipui).

3. Deformuojant elementą, jo taškai gali pasislinkti atstumais, gerokai viršijančiais elemento skerspjūvio matmenis, todèl pusiausvyros sąlygos sudaromos deformuotai sistemai, nustačius jos IDB paskutiniame iteracinio skaičiavimo žingsnyje, t. y. sprendžiamas geometriškai netiesinis uždavinys.

4. Paties konstrukcijos elemento forma nekinta, t. y. deformacijos lieka mažos.

5. Darbe nagrinejjamas erdvinis strypinis elementas, tad laikoma, kad jame vystosi tempimo-gniuždymo, sukimo bei lenkimo dviejų skerspjūvio ašių atžvilgiu įrąžos. 
6. Skerspjūvyje plastinis tekejjimas vyksta visame plote vienu metu. Ribiniai ittempiai pasireiškia visame konstrukcijos elemento skerspjūvio plote. Plastinių deformacijų plitimas skerspjūvio ilgyje nèra nagrinejjamas.

\subsection{Pagrindiniai dydžiai, aprašantys konstrukcijos ịtemptą deformuotą būvị}

Disertaciniame darbe nagrinėjama rèminè konstrukcija savo prigimtimi yra diskretinè. Taigi, sudarant konstrukcijos diskretini modelị (būtent jam ir nagrinejjamas IDB), kiekvieną strypą galima laikyti pavieniu elementu su visuma jam būdingų skaičiuojamujų dydžių. Manoma, kad kiekviename skaičiuojamajame strypo pjūvyje susidaro tokios įrąžos ir deformacijos: ašinè jèga ir linijine deformacija susijusi su strypo pailgejjimu, sukimo momentas ir sąsukio kampinè deformacija, lenkimo momentai apie dvi skerspjūvio ašis ir kampinès deformacijos taip pat apie dvi elemento skerspjūvio ašis. Todẻl strypinès sistemos diskretinị modeli galima gauti visą konstrukciją išskaidžius ị pavienius elementus, esančius tarp konstrukcijos mazgų. Toliau laikysime, kad konstrukcijos diskretinis modelis sudarytas iš baigtinès aibès skaičiuojamujų baigtinių elementų - strypų, kurių eilinis indeksas žymimas $k=1,2, \ldots, s$ (čia $s$ - bendras baigtinių elementų skaičius). Tuomet įrąžu (itempių) tikrasis būvis bet kuriame skaičiuojamojo elemento $k$ mazge $l$ apibūdinamas $n_{k}$-mačiu įrąžų vektoriumi:

$$
\mathbf{S}_{k l} \equiv\left[\begin{array}{llll}
S_{k l, 1} & S_{k l, 2} & \ldots & S_{k l, n_{k}}
\end{array}\right]^{T}, l=1,2, \ldots, v,
$$

čia $v$-mazgų skaičius $k$-ajame elemente. Tuomet $n$-matis vektorius:

$$
\mathbf{S} \equiv\left[S_{j}\right]^{T} \equiv\left[\begin{array}{llllllll}
S_{11} & S_{12} & \ldots & S_{1 v} & \ldots & S_{k l} & \ldots & S_{s v}
\end{array}\right]^{T}, j=1,2, \ldots, n
$$

nusako visos konstrukcijos ittempių būvị. Darbe išskiriami tampraus ir plastinio skaičiavimo (liekamieji) dydžiai, todèl šis vektorius yra lygus:

$$
\mathbf{S}=\mathbf{S}_{e}+\mathbf{S}_{r},
$$

čia $\mathbf{S}_{e}$ yra tampriuju įrąžų vektorius, $\mathbf{S}_{r}$ yra liekamuju ịrąžų vektorius.

Pagal dualią uždavinio formuluotę deformacijos turi būti apibūdinamos tokiu pat $n$-mačiu vektoriumi:

$$
\boldsymbol{\varepsilon} \equiv\left[\varepsilon_{j}\right]^{T} \equiv\left[\begin{array}{llllllll}
\varepsilon_{11} & \varepsilon_{12} & \ldots & \varepsilon_{1 v} & \ldots & \varepsilon_{k l} & \ldots & \varepsilon_{s v}
\end{array}\right]^{T}, j=1,2, \ldots, n .
$$

Šis vektorius yra lygus:

$$
\boldsymbol{\varepsilon}=\boldsymbol{\varepsilon}_{e}+\boldsymbol{\varepsilon}_{r},
$$


čia $\boldsymbol{\varepsilon}_{e}$ yra tampriujų, o $\boldsymbol{\varepsilon}_{r}$ yra liekamujų deformacijų vektoriai.

Kitą dualią kintamųų porą sudaro išorinè apkrova ir poslinkiai. Tegul poslinkiai nagrinèjamame skaičiuojamojo elemento mazge apibūdinami $m_{k}$-mačiu vektoriumi:

$$
\mathbf{u}_{k l} \equiv\left[\begin{array}{llll}
u_{k l, 1} & u_{k l, 2} & \ldots & u_{k l, m_{k}}
\end{array}\right]^{T}, l=1,2, \ldots, v .
$$

Tuomet apkrova šiame mazge taip pat turi būti apibūdinama tokių pat matmenų vektoriumi:

$$
\mathbf{F}_{k l} \equiv\left[\begin{array}{llll}
F_{k l, 1} & F_{k l, 2} & \ldots & F_{k l, m_{k}}
\end{array}\right]^{T}, l=1,2, \ldots, v .
$$

Diskretiniam konstrukcijos modeliui gaunami du $m$-mačiai vektoriai:

$$
\begin{gathered}
\mathbf{u} \equiv\left[u_{j}\right]^{T} \equiv\left[\begin{array}{llllllll}
u_{11} & u_{12} & \ldots & u_{1 v} & \ldots & u_{k l} & \ldots & u_{s v}
\end{array}\right]^{T}, \\
\mathbf{F} \equiv\left[F_{j}\right]^{T} \equiv\left[\begin{array}{llllllll}
F_{11} & F_{12} & \ldots & F_{1 v} & \ldots & F_{k l} & \ldots & F_{s v}
\end{array}\right]^{T}, i=1,2, \ldots, m .
\end{gathered}
$$

Analogiškai įtempių būviui, vektorius u skaidomas:

$$
\mathbf{u}=\mathbf{u}_{e}+\mathbf{u}_{r},
$$

čia $\mathbf{u}_{e}$ yra tampriujų, o $\mathbf{u}_{r}$ yra liekamujų poslinkių vektorius.

\subsection{Konstrukcijų optimizavimo uždavinio matematinis modelis}

Šiame disertaciniame darbe nagrinejjamas rèminių konstrukcijų optimizavimo uždavinys yra formuluojamas taip: žinant rèmo konfigūraciją ir išorines jègas, reikia rasti strypų skerspjūvių plotų $A_{k}$ pasiskirstymą, tenkinantị minimalaus tūrio konstrukcijos optimalumo kriterijų, kai atskiri konstrukcijos elementai patiria plastiškąsias deformacijas. Nagrinejjamo optimizavimo uždavinio kompleksiniai apribojimai turi apimti, visų pirma, sąlygas, apibūdinančias konstrukcijos tikraji IDB. Tokios sąlygos yra apibendrinto Lagranžo uždavinio priklausomybès. Antra, standumo sąlygos turi apimti poslinkių apribojimus norimose konstrukcijos vietose tam tikromis $t$ kryptimis: $\mathbf{u}_{t}^{-} \leq \mathbf{u}_{e, t}+\mathbf{u}_{r, t} \leq \mathbf{u}_{t}^{+}$. Čia $\mathbf{u}_{t}^{+}$ir $\mathbf{u}_{t}^{-}-$poslinkių viršutinių ir apatinių ribų normatyvinès reikšmès. Be šių būtinų sąlygų gali būti ir kitokio pobūdžio technologiniai ar konstrukciniai apribojimai elementų stabilumui ar ribinių ịąžu apatinei kitimo ribai $\mathbf{S}_{0}^{\min }$. Tai riboja laisvą konstrukcijos netamprių deformacijų plitimą, todèl optimalių skerspjūvių 
konstrukcijos elementuose atsiranda ir tampriosios ir plastiškosios deformacijos, sąlygojamos liekamujų įrąžų $\mathbf{S}_{r}$ ir poslinkių $\mathbf{u}_{r}$. Jei šie stiprumo apribojimai netenkinami kaip lygybès, tai konstrukcija nepasiekia plastiškosios irties (Čyras et al. 2004, Karkauskas 2004). Tokiu būdu suformuluoto optimizavimo uždavinio matematinis modelis yra užrašomas taip:

Rasti

$$
V\left(A_{k}\right) \rightarrow \min ,
$$

kai

$$
\mathbf{f}\left(\mathbf{S}_{e}, \mathbf{S}_{r}, \mathbf{S}_{0}\left(A_{k}\right)\right) \leq \mathbf{1},
$$

$$
\begin{aligned}
& \mathbf{A}_{n} \mathbf{S}_{r}=\mathbf{F}-\mathbf{A}_{n} \mathbf{S}_{e}, \\
& \mathbf{D}_{n} \boldsymbol{S}_{r}-\mathbf{A}_{n}{ }^{T} \boldsymbol{u}_{r}+\left[\nabla^{T} \mathbf{f}\left(\mathbf{S}_{e}, \mathbf{S}_{r}, \mathbf{S}_{0}\left(A_{k}\right)\right)\right] \boldsymbol{\lambda}=\mathbf{0}, \\
& \boldsymbol{\lambda}^{T}\left(\mathbf{1}-\mathbf{f}\left(\mathbf{S}_{e}, \mathbf{S}_{r}, \mathbf{S}_{0}\left(A_{k}\right)\right)\right)=\mathbf{0}, \\
& \mathbf{u}_{t}^{-} \leq \mathbf{u}_{e, t}+\mathbf{u}_{r, t} \leq \mathbf{u}_{t}^{+}, \mathbf{S}_{0}\left(A_{k}\right) \geq \mathbf{S}_{0}^{\min }, \boldsymbol{\lambda} \geq \mathbf{0}, k=1,2, \ldots, s,
\end{aligned}
$$

čia $A_{k}$ yra konstrukcijos $k$-osios elementų grupès skerspjūvio plotas; $\mathbf{S}_{0}$ yra ịrąžų ribinių reikšmių vektorius; $\mathbf{D}_{\mathrm{n}}$ yra $(n \times n)$ matmenų konstrukcijos baigtinių elementų kvazidiagonalioji pasiduodamumo matrica, ivvertinanti geometrijos kitimą apkrovimo procese; $\mathbf{A}_{n}$ yra $(m \times n)$ matmenų pusiausvyros lygčių koeficientų matrica, susieta su diskretinio modelio poslinkiais; $n$ yra nežinomujjų įrąžų skaičius; $m$ yra konstrukcijos laisvumo laipsnis (galimų poslinkių skaičius); $\lambda$ yra Lagranžo daugikliu vektorius.

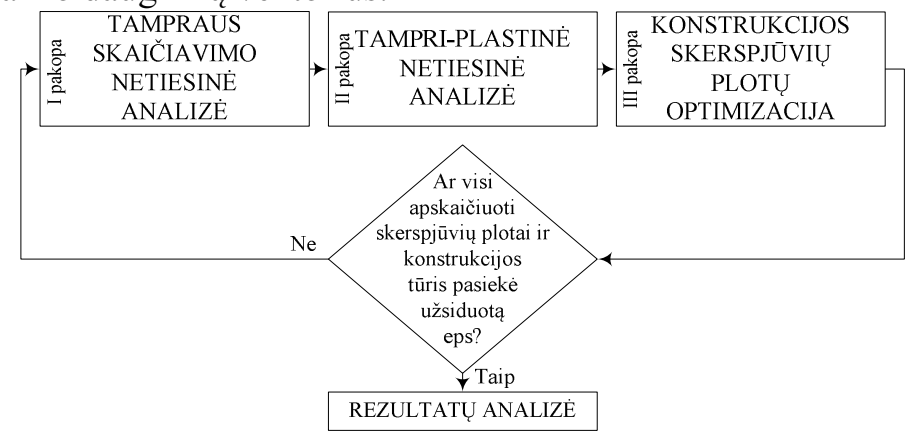

1.3 pav. Optimizavimo uždavinio sprendimo algoritmas

Fig. 1.3. The solution algorithm for the optimization problem

Tai netiesinio matematinio programavimo daugiaekstreminis uždavinys. Daugiaekstremališkumas susidaro dèl Kuno ir Takerio papildomumo (matematiniame programavime griežtumo) sąlygos t. y. sandaugos $\lambda^{T}\left(\mathbf{1}-\mathbf{f}\left(\mathbf{S}_{e}, \mathbf{S}_{r}, \mathbf{S}_{0}\left(A_{k}\right)\right)\right)=\mathbf{0}$. Šis uždavinys sprendžiamas iteraciniu būdu, ši aplinkybė ir komplikuoja uždavinio skaitinių rezultatų gavimą. Todèl darbe sukurtas originalus konstrukcijų netiesinès optimizacijos algoritmas, 
realizuojantis iteracines procedūras pačiame optimizavimo proceso cikle (pats optimizavimo uždavinio ciklas apima tris pakopas). Optimizavimo uždavinio sprendimo algoritmo bendras schematinis vaizdas yra pateiktas 1.3 paveiksle.

\subsection{Optimizavimo uždavinių skaitinis realizavimas}

Optimizavimo uždavinių skaitinè realizacija yra tampriai susieta su kompiuterinių technologijų vystymu. Besivystančios kompiuterinès programavimo technologijos suteikè galimybę kurti programinę ịrangą, leidžiančią spręsti ìvairius optimizavimo uždavinius. Didelį postūmį šioje srityje padare programavimo kalbos (pavyzdžiui, Fortran - kalba specialiai sukurta mokslinių uždavinių sprendimui). Programos dažniausiai buvo kuriamos dažniausiai vieno žmogaus (programuotojo). Naudojantis programavimo kalba, duomenų ịvedimas bei rezultatų pateikimas ir apdorojimas buvo vykdomas pagal griežtas programos kūrejjo nustatytas taisykles ir dažniausiai neturejjo „draugiškos“ vartotojui aplinkos. Tokių programų kūrimo procesas buvo gana sudètingas bei reikalaujantis didelių žmogiškujų resursų. Kaip pavyzdi galima paminèti VGTU mokslininkų sukurtas programas (Karkauskas et al. 1995) - Atkočiūno „Rutamini“, Kalantos „Simplex“, Karkausko „Kvadpr“, kitu autorių kolektyvų „SM115“, „SM3“, „SM4“ darbo rezultatus ir kitas. Fortran programavimo kalba ir šiandien dažnai naudojama atliekant inžinerinius skaičiavimus (Smith et al. 2004).

Be pavienių mokslininkų kuriamų individualių programų, kurios dažniausiai būdavo pritaikytos spręsti gana siaurą spektrą uždavinių, pasaulyje buvo kuriamos bei vystomos matematinių skaičiavimų programos, apjungiančios dideli kiekị matematinių funkcijų, leidžiančių spręsti ịvairius uždavinius. Kaip pavyzdị būtų galima pateikti amerikiečių mokslininkų 1970 metų pabaigoje pradètą kurti kompiuterinę matematinę sistemą bei turinčią tokị pat pavadinimą aukšto lygio mokslinių techninių skaičiavimų kalbą MATLAB (Chapra 2006; Palm 2010; MathWorks 2012; Quarteroni et al. 2010). Šios programos sukūrimo pagrindinè ideja buvo: suteikti vartotojams (studentams) galimybę naudoti ivairias programines bei skaičiavimo bibliotekas be būtinybès mokèti pačią programavimo kalbą. Iš pradžių MATLAB buvo vystoma kaip atviro kodo programinè ịranga, bet 1984 metais programos kūrèjai ịkūrè kompaniją „The MathWorks", kuri ir iki šiol rūpinasi šios programos vystymu bei platinimu. Dabar MATLAB yra plačiai vartojama universitetuose ir mokslinių tyrimų centruose. Šiuolaikinès, naujausios šios programos versijos turi „draugišką““ vartotojui aplinką, leidžia atlikti skaičiavimus komandų réžimu, sprendžiant sudètingus uždavinius, sukurti bei modifikuoti nuosavas programas. MATLAB, kaip skaičiavimų kalba, turi savo ypatumų, t. y. tam tikrų taisyklių, reikalingų sukurti savo programą ar atlikti skaičiavimus, bet šie ypatumai yra daug 
paprastesni palyginus su bet kuria kita programavimo kalba. Kitaip tariant, MATLAB kalba - tai tipine i problemą orientuota aukšto lygio programavimo kalba. Ji turi operatorius ir funkcijas, kuriu realizacija bet kuria programavimo kalba pareikalautu daug laiko. Programavimo kalba MATLAB turi priemonių, kurios leidžia realizuoti ịvairias programavimo rūšis: procedūrinį, operatorinį, funkcinį, logini, struktūrini, objektini, vaizdinị. Vaizdini programavimą padeda realizuoti sistema Simulink, esanti MATLAB branduolyje. Tai leidžia kurti bei vykdyti programas ne tik MATLAB terpeje, bet ir atskiras savarankiškas ir nepriklausomas nuo MATLAB terpès programas. MATLAB, taipogi, gerai pritaikoma atliekant baigtinių elementų skaičiavimus (Asghar Bhatti 2005; Ferreira 2009; Kwon et al. 2000).

Greta paprastų matematinių skaičiavimų funkcijų, MATLAB programa turi daug kompiliuotų funkcijų, įrankių rinkinių-bibliotekų, iš kurių šio darbo kontekste svarbu paminèti dvi:

- Symbolic Math Toolbox - simbolinių skaičiavimu funkciju biblioteka, leidžianti gauti tangentinių standumo matricų analitines išraiškas, reikalingas tampraus skaičiavimo netiesinei analizei;

- Optimization Toolbox - optimizavimo uždavinių sprendimo funkcijų biblioteka, leidžianti išspręsti įvairaus sudètingumo bei įvairių rūšių optimizavimo uždavinius.

Sprendžiant ịvairius geometriškai netiesinių tamprių plastinių rèmų analizės bei optimizavimo uždavinius gali būti taikoma optimizavimo paprogramè fmincon. Šios paprogramès sprendžiamas matematinio programavimo uždavinys turi turèti tokią matematinio modelio formą:

Rasti

$\min \mathbf{f}(\mathbf{x})$

kai

$$
\left\{\begin{array}{l}
\mathbf{c}(\mathbf{x}) \leq \mathbf{0}, \mathbf{c}_{e q}(\mathbf{x}) \leq \mathbf{0}, \\
\mathbf{A x} \leq \mathbf{b}, \mathbf{A}_{e q}(\mathbf{x})=\mathbf{b}_{e q}, \\
\mathbf{l b} \leq \mathbf{x} \leq \mathbf{u b},
\end{array}\right.
$$

čia $\mathbf{f}(\mathbf{x})$ - optimizavimo uždavinio tikslo funkcija; $\mathbf{c}(\mathbf{x})$ - optimizavimo uždavinio apribojimų sąlygų-nelygybių, išreikštų funkcinèmis priklausomybėmis matrica; $\mathbf{c}_{e q}(\mathbf{x})$ - optimizavimo uždavinio apribojimų sąlygų-lygybių, išreikštų funkcinėmis priklausomybèmis, matrica; $\mathbf{A}$ - optimizavimo uždavinio apribojimų sąlygų-nelygybių, išreikštų tiesinèmis priklausomybèmis, matrica; b optimizavimo uždavinio apribojimų sąlygų-nelygybių, išreikštų tiesinėmis priklausomybèmis, laisvujų narių vektorius; $\mathbf{A}_{e q}$ - optimizavimo uždavinio apribojimų sąlygų-lygybių, išreikštų tiesinėmis priklausomybėmis, matrica; $\mathbf{b}_{e q}-$ optimizavimo uždavinio apribojimų sąlygų-lygybių, išreikštų tiesinèmis 
priklausomybėmis, laisvujų narių vektorius; lb, ub - optimizavimo uždavinio nežinomujų vektorius apatinių ir viršutinių ribų vektoriai.

Paprogramė fmincon yra ìvairių pasirinkčių, leidžiančių kontroliuoti optimizavimo uždavinio sprendimo eigą. Viena iš svarbiausiųų pasirinkčių yra galimybe pasirinkti uždavinio sprendimo algoritmą. Paprogramė fmincon sprendžia uždavinius, naudojant active-set; interior-point, sqp ir trust-regionreflective algoritmus, kurie yra plačiai pristatyti mokslinejje literatūroje (Rao 2009, MathWorks Inc. 2012).

Svarbu pažymèti, kad sprendžiant tiesioginius optimizavimo uždavinius MATLAB, programa iš karto pateikia optimizavimo uždavinių dualių formuluočių dydžius.

\subsection{Pirmojo skyriaus išvados ir disertacijos uždavinių formulavimas}

Mokslinejje literatūroje nèra skirta pakankamai dèmesio geometriškai netiesinių tamprių plastinių statybinių strypinių konstrukcijų skaičiavimo ir optimizavimo, ribojant konstrukcijos poslinkius, problematikai. Svarbiausios išvados:

1. Atlikta analitinè mokslinès literatūros apžvalga parodè tamprių plastinių geometriškai netiesinių strypinių konstrukcijų optimizavimo, ribojant poslinkius, aktualumą (šia tema parašyta nedaug teorinių ir statybos konstrukcijų eksperimentinès plètros darbų).

2. Optimizavimo uždavinių formuluotès turi būti grindžiamos matematiniu programavimu ir mechanikos ekstreminiais energiniais principais.

3. Optimizavimo metodikai būtina: sudaryti geometriškai netiesinių tamprių plastinių statybinių strypinių konstrukcijų skaičiavimo ir optimizavimo uždavinių matematinius modelius, ribojant konstrukcijos poslinkius; skaitinei realizacijai sukurti naują iteracinį sprendimo algoritmą.

Remiantis aukščiau pateiktomis išvadomis formuluojami pagrindiniai darbo uždaviniai:

1. Suformuluoti geometriškai netiesinès tamprios plastinès erdvinès strypinès konstrukcijos analizès uždavinio matematini modelį. Gautus rezultatus palyginti su kitų autorių gautais rezultatais.

2. Pletoti erdvinio baigtinio elemento tangentinès standumo matricos sudarymo metodiką ir simbolinių skaičiavimų programą šios matricos išraiškai gauti.

3. Suformuluoti ir išspręsti tamprių plastinių geometriškai netiesinių erdvinių strypinių konstrukcijų ribojant poslinkius optimizavimo uždavinį. Atlikti skaitinių eksperimentų lyginamają analizę. 
4. Sujungti antros eilès tampraus skaičiavimo, tamprios plastinès konstrukcijos analizès bei optimizavimo ribojant poslinkius uždavinius i vieną bendrą iteracinį sprendimo algoritmą.

5. Naudojant sukurtą programinę įrangą, modeliavimo būdu patikrinti siūlomo optimizavimo uždavinio sprendimo algoritmo veiksmingumą ir efektyvumą. 



\section{2}

\section{Geometriškai netiesinių konstrukciju analizè}

Šiame skyriuje aprašytos pasiūlyto algoritmo du pirmieji skaičiavimo etapai tampraus skaičiavimo netiesinè analizè bei tamprių plastinių konstrukcijų analizè. Pateikiami šių metodų formulavimai, leidžiantys apskaičiuoti reikalingus dydžius, bei skaitinès realizacijos galimybes. Pagrindžiamas ekstreminio energinio principo taikymas sprendžiant optimizavimo uždavinius. Pateikiami atlikto skaitinio eksperimento rezultatai.

Skyriaus tematika paskelbti šeši straipsniai (Karkauskas, Popov 2009 a; Karkauskas, Popov 2009 b; Popov et al. 2010 a, Popov et al. 2010 b; Karkauskas, Popov 2011, Popov et al. 2013). Rezultatai buvo pristatyti trijose tarptautinèse mokslinèse konferencijose - tarptautinèje mokslinèje konferencijoje „Modern building materials, structures and techniques“ $2010 \mathrm{~m}$. Vilniuje; „Optimization and Analysis of Structures“ 2011 m. Tartu, Estijoje, bei „Задачи и методы компьютерного моделирования конструкций и сооружений“ (,,Золотовские чтения") 2013 m. Maskvoje, Rusijoje bei dviejose jaunuju mokslininku konferencijose „Mokslas - Lietuvos ateitis“ 2009 ir 2012 m. Vilniuje. 


\subsection{Konstrukcijos tangentinè standumo matrica}

Reali konstrukcija turi begalinị laisvès laipsnį. Sprendžiant konstrukcijos analizès bei optimizavimo uždavinius tenka naudotis skaitinio modeliavimo metodais. Tam reikia pereiti nuo begalinio konstrukcijos laisvès laipsnio prie baigtinio laisvès laipsnio. Tai realizuojama diskretizacijos procesu, kurio rezultatas yra konstrukcijos diskretinis modelis. Ši procesą galima atlikti baigtinių elementų, kraštinių elementų, baigtinių skirtumų metodais (Секулович 1993;Reddy 2004; Reddy 2005; Zienkiewicz and Taylor 2005; Wriggers 2008).

Baigtinių elementų metodas (BEM) buvo kuriamas tamprumo ir plastiškumo teorijų bei statybinès mechanikos lygtims spręsti. Šiuo metu šiuolaikinèse statybinių konstrukcijų analizès ir projektavimo programose BEM tapo standartiniu.

Optimizavimo uždavinio (1.7) sprendimo siūlomo algoritmo tampraus skaičiavimo netiesinès analizès uždavinys sprendžiamas naudojant baigtinių elementų tangentinio standumo metodo (Barauskas 1998, Barauskas et al. 2004) pusiausvyros lygtį:

$$
\mathbf{K}_{\tau} \mathbf{u}_{e}=\mathbf{F},
$$

čia $\mathbf{K}_{\tau}=\mathbf{K}_{e}+\mathbf{K}_{g}+\mathbf{K}_{u}-$ konstrukcijos tangentinè standumo matrica; $\mathbf{K}_{e}-$ konstrukcijos mažų poslinkių (tampraus skaičiavimo) standumo matrica; $\mathbf{K}_{g}-$ konstrukcijos geometrinè standumo matrica, ivertinanti konstrukcijos deformuoto būvio įtaką jos standumui; $\mathbf{K}_{u}$ - konstrukcijos pradinių poslinkių standumo matrica.

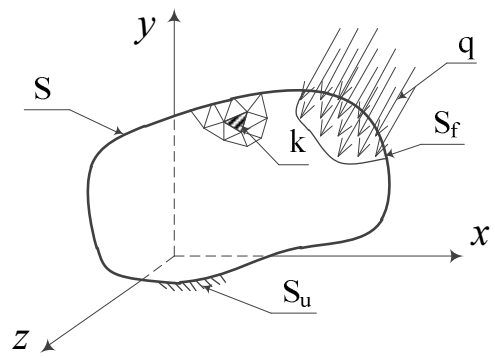

2.1 pav. Kūnas ir jo diskretizavimas baigtiniais elementais

Fig. 2.1. A body and it's discretization by finite elements

Žemiau pateikiama detali konstrukcijos tangentinès standumo matricos sudarymo eiga BEM. Šios matricos sudarymui bus naudojamas variacinis metodas, grindžiamas pilnutinès diskretizuoto kūno potencinès energijos $\Pi$ stacionarumo sąlyga (Atkočiūnas et al. 2004, Barauskas et al. 2004), tiksliau sakant pirmoji funkcionalo $\Pi$ variacija, kuri yra lygi nuliui: 


$$
\partial \Pi=0 .
$$

Nagrinejjamas kūnas, kurio tūris $V$ yra apribotas uždaru paviršiumi $S$. Kūnas yra suskaidomas i baigtinị skaičių elementų $k$, kaip pavaizduota 2.1 paveiksle. Išorinès jègos, veikiančios elemento taškus, yra paskirstytos tūrinès jègos $\mathbf{g}(\mathbf{x})=\left[\begin{array}{llll}g_{x}(x, y, z) & g_{y}(x, y, z) & g_{z}(x, y, z)\end{array}\right]^{T}$, paviršiaus $S$ dalyje $S_{f}$ veikiančios paviršinès paskirstytos jègos $\mathbf{q}(\mathbf{x})=\left[\begin{array}{lll}q_{x}(x, y, z) & q_{y}(x, y, z) \quad q_{z}(x, y, z)\end{array}\right]^{T}$ ir elementų tarpusavio sąveikos mazginès jègos $\mathbf{F}(\mathbf{x})=\left[\begin{array}{llll}F_{x}(x, y, z) & F_{y}(x, y, z) & F_{z}(x, y, z)\end{array}\right]^{T}$. Kūno paviršiaus dalyje $S_{u}$ baigtinių elementu bet kurio taško poslinkiai $\mathbf{u}(\mathbf{x})=\left[\begin{array}{lll}u_{x}(x, y, z) & u_{y}(x, y, z) & u_{z}(x, y, z)\end{array}\right]^{T}$ yra apriboti, t. $\mathbf{y} . \mathbf{u}(\mathbf{x})=\mathbf{0}$ paviršiuje $S_{u}$. Taigi, šiame paviršiuje elemento taškus veikia reakcijos $\mathbf{r}(\mathbf{x})$.

Tamprumo teorijos uždaviniuose pilnutinè diskretizuoto kūno potenciné energija aprašoma išraiška:

$$
\Pi=U+\Omega,
$$

čia $U$ - potencinè kūno deformavimo energija (vidinių jègu potencialas); $\Omega-$ potencinè išorinių jègų energija (išorinių jègų potencialas).

Potencinę kūno deformavimo energiją nulemia paskirų baigtinių elementų potenciné deformavimo energija, t. y.:

$$
U=\sum_{k=1}^{s} U_{k},
$$

čia $s$ - baigtinių elementų skaičius; $U_{k}$ - įtempto ir deformuoto baigtinio elemento potencinė energija, kuri išreiškiama:

$$
U_{k}=\frac{1}{2} \int_{V_{k}} \boldsymbol{\varepsilon}_{k}(\mathbf{x})^{T} \boldsymbol{\sigma}_{k}(\mathbf{x}) d V_{k},
$$

čia $\boldsymbol{\varepsilon}_{k}(\mathbf{x})-k$-ojo baigtinio elemento deformacijų vektorius, bet kuriame elemento taške; $\boldsymbol{\sigma}_{k}(\mathbf{x})-k$-ojo baigtinio elemento įtempių vektorius, bet kuriame elemento taške.

Išorinių jègų potencialą nulemia išorinių jègų darbas, atliktas paskirų elementų bet kurio taško poslinkiuose $\mathbf{u}(\mathbf{x})=\left[\begin{array}{lll}u_{x}(x, y, z) & u_{y}(x, y, z) & u_{z}(x, y, z)\end{array}\right]^{T}$ ir mazginių taškų poslinkiuose, kurie apibūdinami vektoriumi $\mathbf{u}_{k}^{\prime}$ : 


$$
\Omega_{k}=-\int_{V_{k}} \mathbf{u}(\mathbf{x})^{T} \mathbf{g}(\mathbf{x}) d V_{k}-\int_{S_{f, k}} \mathbf{u}(\mathbf{x})^{T} \mathbf{q}(\mathbf{x}) d V_{k}-\int_{V_{k}} \mathbf{u}_{k}^{\prime T} \mathbf{F}_{k}^{\prime} d V_{k},
$$

čia $\mathbf{u}_{k}^{\prime}-k$-ojo baigtinio elemento mazginių poslinkių vektorius; $\mathbf{F}_{k}^{\prime}-k$-ojo baigtinio elemento mazginių jègų vektorius.

Diskretizuoto kūno elemento pilnutinè potencinè energija $\Pi$ bus gauta susumavus paskirų baigtinių elementų vidinių ir išorinių jègų potencialus (2.5) ir (2.6). Tuomet gaunama tokia pilnutinès potencinès energijos išraiška:

$$
\begin{aligned}
\Pi_{k}= & \frac{1}{2} \int_{V_{k}} \boldsymbol{\varepsilon}_{k}(\mathbf{x})^{T} \boldsymbol{\sigma}_{k}(\mathbf{x}) d V_{k}- \\
& \int_{V_{k}} \mathbf{u}(\mathbf{x})^{T} \mathbf{g}(\mathbf{x}) d V_{k}-\int_{S_{f, k}} \mathbf{u}(\mathbf{x})^{T} \mathbf{q}(\mathbf{x}) d V_{k}-\int_{V_{k}} \mathbf{u}_{k}^{\prime T} \mathbf{F}_{k}^{\prime} d V_{k} .
\end{aligned}
$$

Naudojantis pilnutinès potencinès energijos stacionarumo sąlygomis (Lagranžo variaciniu principu), gaunamos baigtinio elemento pusiausvyros lygtys, parašytos remiantis mazginiais poslinkiais:

$$
\begin{aligned}
\frac{\partial \Pi_{k}}{\partial \mathbf{u}_{k}^{\prime}}= & \frac{\partial}{\partial \mathbf{u}_{k}^{\prime}}\left(\frac{1}{2} \int_{V_{k}} \boldsymbol{\varepsilon}_{k}(\mathbf{x})^{T} \boldsymbol{\sigma}_{k}(\mathbf{x}) d V_{k}\right)- \\
& \frac{\partial}{\partial \mathbf{u}_{k}^{\prime}}\left(\int_{V_{k}} \mathbf{u}(\mathbf{x})^{T} \mathbf{g}(\mathbf{x}) d V_{k}+\int_{S_{f, k}} \mathbf{u}(\mathbf{x})^{T} \mathbf{q}(\mathbf{x}) d V_{k}+\int_{V_{k}} \mathbf{u}_{k}^{\prime T} \mathbf{F}_{k}^{\prime} d V_{k}\right)=0 .
\end{aligned}
$$

Ši lygtis yra baigtinio elemento pusiausvyros netiesine lygtis, nes ir itempių funkcija $\boldsymbol{\sigma}_{k}(\mathbf{x})$ taip pat yra išreiškiama poslinkiais $\mathbf{u}_{k}^{\prime}$. Šią lygti galime užrašyti taip:

$$
\Psi_{k}\left(\mathbf{u}_{k}^{\prime}\right)-\mathbf{F}_{g, k}-\mathbf{F}_{q, k}-\mathbf{F}_{k}^{\prime}=0
$$

čia $\mathbf{F}_{g, k}-k$-ojo baigtinio elemento mazginiu jęgų vektorius, sąlygotas paskirstytujų tūrinių jègų; $\mathbf{F}_{q, k}-k$-ojo baigtinio elemento mazginių jègų vektorius, sąlygotas paskirstytujų paviršinių jègų;

$$
\boldsymbol{\Psi}_{k}\left(\mathbf{u}_{k}^{\prime}\right)=\int_{V_{k}}\left\{\frac{\partial \boldsymbol{\varepsilon}_{k}(\mathbf{x})}{\partial \mathbf{u}_{k}^{\prime}}\right\}^{T} \boldsymbol{\sigma}_{k}(\mathbf{x}) d V_{k},
$$

o jo išvestine: 


$$
\frac{\partial \Psi_{k}\left(\mathbf{u}_{k}^{\prime}\right)}{\partial \mathbf{u}_{k}^{\prime}}=\mathbf{k}_{\tau}\left(\mathbf{u}_{k}^{\prime}\right),
$$

yra vadinama baigtinio elemento tangentine standumo matrica. Matome, kad elemento tangentinès standumo matricos fizinè prasmé yra netiesinès elemento pusiausvyros lygties (2.8) pirmasis dèmuo - Jakobio matrica, apskaičiuota esant žinomiems elemento mazginiams poslinkiams $\mathbf{u}_{k}^{\prime}$. Reikia pažymèti, kad kvadratinès matricos $\mathbf{k}_{\tau}\left(\mathbf{u}_{k}^{\prime}\right)$ matmuo priklauso nuo elemento mazginiu poslinkių vektoriaus $\mathbf{u}_{k}^{\prime}$ ilgio. Jos eilutès narius gauname diferencijuojant (2.11) pagal vieną iš vektoriaus $\mathbf{u}_{k}^{\prime}$ komponentų:

$$
\mathbf{k}_{\tau}\left(\mathbf{u}_{k}^{\prime}\right)=\left[\begin{array}{l}
\frac{\partial \boldsymbol{\Psi}_{k}\left(\mathbf{u}_{k}^{\prime}\right)}{\partial \mathbf{u}_{1}^{\prime}}=\frac{\partial}{\partial \mathbf{u}_{1}^{\prime}} \int_{V_{k}}\left\{\frac{\partial \boldsymbol{\varepsilon}_{k}(\mathbf{x})}{\partial \mathbf{u}_{1}^{\prime}}\right\}^{T} \boldsymbol{\sigma}_{k}(\mathbf{x}) d V_{k} \\
\frac{\partial \mathbf{u}_{2}^{\prime}}{\left.\mathbf{u}_{k}^{\prime}\right)}=\frac{\partial}{\partial \mathbf{u}_{2}^{\prime}} \int_{V_{k}}\left\{\frac{\partial \boldsymbol{\varepsilon}_{k}(\mathbf{x})}{\partial \mathbf{u}_{2}^{\prime}}\right\}^{T} \boldsymbol{\sigma}_{k}(\mathbf{x}) d V_{k} \\
\frac{\partial \boldsymbol{\Psi}_{k}\left(\mathbf{u}_{k}^{\prime}\right)}{\partial \mathbf{u}_{3}^{\prime}}=\frac{\partial}{\partial \mathbf{u}_{3}^{\prime}} \int_{V_{k}}\left\{\frac{\partial \boldsymbol{\varepsilon}_{k}(\mathbf{x})}{\partial \mathbf{u}_{3}^{\prime}}\right\}^{T} \boldsymbol{\sigma}_{k}(\mathbf{x}) d V_{k} \\
\frac{\partial \boldsymbol{\Psi}_{k}\left(\mathbf{u}_{k}^{\prime}\right)}{\partial \mathbf{u}_{n}^{\prime}}=\frac{\partial}{\partial \mathbf{u}_{n}^{\prime}} \int_{V_{k}}\left\{\frac{\partial \boldsymbol{\varepsilon}_{k}(\mathbf{x})}{\partial \mathbf{u}_{n}^{\prime}}\right\}^{T} \boldsymbol{\sigma}_{k}(\mathbf{x}) d V_{k}
\end{array}\right] .
$$

Geometriniai netiesiškumai yra sąlygoti netiesinès poslinkių ir deformacijų priklausomybès. Vadinasi, šios matricos (2.12) reikšmè netiesiogiai priklauso nuo mazginių poslinkių $\mathbf{u}_{k}^{\prime}$. Nuo jų priklauso deformacijų $\boldsymbol{\varepsilon}_{k}(\mathbf{x})$ reikšmès, o nuo deformacijų priklauso įtempių $\boldsymbol{\sigma}_{k}(\mathbf{x})$ reikšmès.

\subsection{Rèminis strypinis erdvinis elementas}

\subsubsection{Elemento formos funkcijos}

Šiame darbe pristatoma nagrinejjamo erdvinès rèminès konstrukcijos elemento (2.2 pav.) tangentinès standumo matricos sudarymo metodika. 


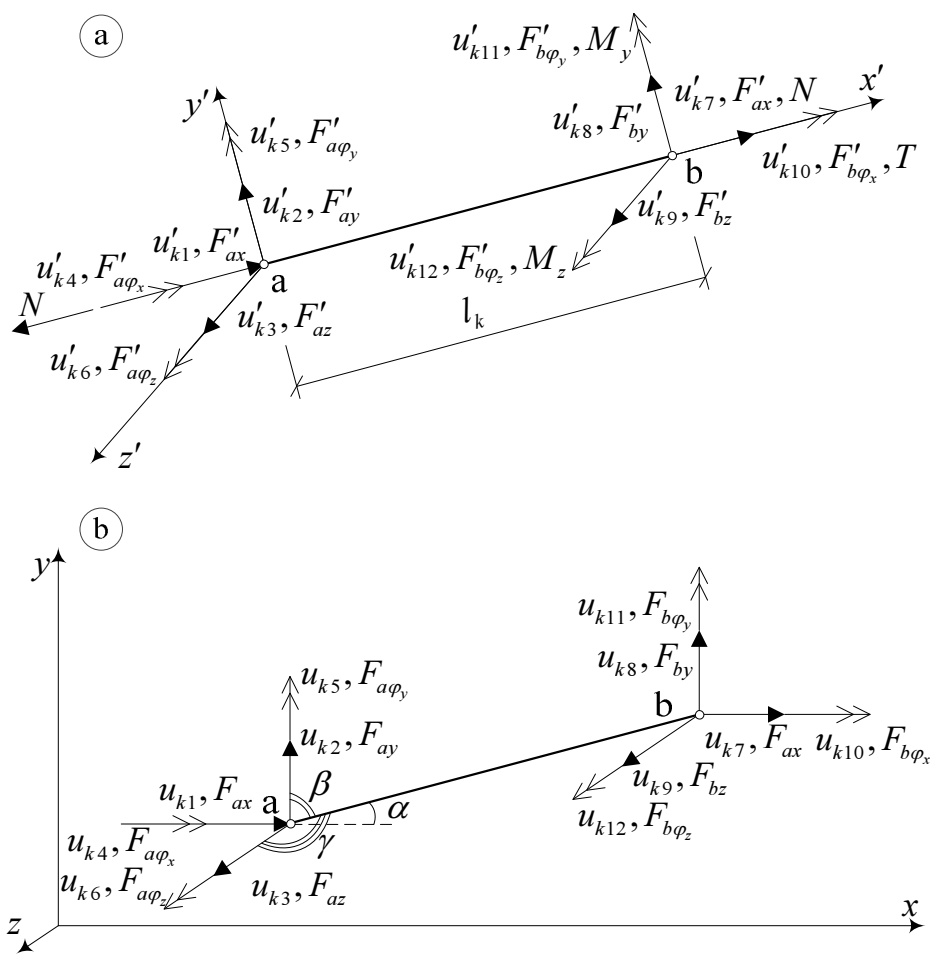

2.2 pav. Erdvinis reminis baigtinis elementas

Fig. 2.2. The three-dimensional frame finite element

Tempiamo-gniuždomo, sukamo bei kartu lenkiamo elemento mazginių poslinkių vektorius lokaliojoje koordinačių sistemoje, bus parašomas elemento galų išilginiais, skersiniais ir kampiniais poslinkiais (2.2 pav., a):

$$
\begin{aligned}
\mathbf{u}_{k}^{\prime}=\left[\begin{array}{lllllll}
u_{k 1}^{\prime} & u_{k 2}^{\prime} & u_{k 3}^{\prime} & u_{k 4}^{\prime} & u_{k 5}^{\prime} & u_{k 6}^{\prime} \\
& u_{k 7}^{\prime} & u_{k 8}^{\prime} & u_{k 9}^{\prime} & u_{k 10}^{\prime} & u_{k 11}^{\prime} & u_{k 12}^{\prime}
\end{array}\right]^{T} .
\end{aligned}
$$

Šio vektoriaus komponentai $u_{k 1}^{\prime}$ ir $u_{k 7}^{\prime}$ yra elemento mazginių taškų linijiniai poslinkiai, kurie sutampa su elemento lokalios ašies $x^{\prime}$ kryptimi. Komponentai $u_{k 2}^{\prime}$ ir $u_{k 8}^{\prime}$ yra linijiniai poslinkiai elemento lokalios ašies $y^{\prime}$ kryptimi. Komponentai $u_{k 3}^{\prime}$ ir $u_{k 9}^{\prime}$ yra linijiniai poslinkiai elemento lokalios ašies $z^{\prime}$ kryptimi. Komponentai $u_{k 4}^{\prime}$ ir $u_{k 10}^{\prime}$ yra kampiniai sukimo poslinkiai apie elemento lokaliają aši $x^{\prime}$, kurių kryptys sutampa su laikrodžio rodyklès judejimo kryptimi žiūrint iš teigiamos ašies pusès. Komponentai $u_{k 5}^{\prime}$ ir $u_{k 11}^{\prime}$ yra kampiniai elemento posūkiai apie lokaliąją aši $y^{\prime}$, kurių kryptis sutampa su laikrodžio 
rodyklès judejjimo kryptimi žiūrint iš teigiamos ašies pusès. Komponentai $u_{k 6}^{\prime}$ ir $u_{k 12}^{\prime}$ yra kampiniai posūkiai apie elemento lokaliają aši $z^{\prime}$, kurių kryptis sutampa su laikrodžio rodyklès judejjimo kryptimi žiūrint iš teigiamos ašies pusès. Taigi erdvinès rèminès konstrukcijos elementas lokaliojoje koordinačių sistemoje $x^{\prime} y^{\prime} z^{\prime}$ turi dvylika laisvumo laipsnių. Tokio elemento bet kurio taško linijinis poslinkis elemento lokalios ašies $x^{\prime}$ kryptimi (elemento pailgejjimas ar sutrumpejjimas) bei sukimas apie šią aši yra apibrěžiami tiesinèmis funkcijomis $u_{k x}^{\prime}(x)$ ir $\varphi_{k x}^{\prime}(x)$, o linijiniai poslinkiai elemento lokalių ašių $y^{\prime}$ ir $z^{\prime}$ kryptimis - netiesinèmis funkcijomis $u_{k y}^{\prime}(x)$ ir $u_{k y}^{\prime}(x)$. Šių funkcijų aproksimacijai dažniausiai naudojami Ermito polinomai (Barauskas, R. 1998, Barauskas, R. et al. 2004). Ermito polinomus, jų nežinant, bet kurio taško poslinkių funkcijų interpoliavimui per elemento mazginius taškus, galima gauti interpoliacines funkcijas parenkant tam tikro polinomo pavidalu.

Laikoma, kad strypų tempimo-gniuždymo bei sukimo poslinkių funkcijos aproksimuojamos tiesiniais polinomais:

$$
\begin{gathered}
u_{k x}^{\prime}(x)=a_{0}+a_{1} x=\left[\begin{array}{ll}
1 & x
\end{array}\right]\left\{\begin{array}{l}
a_{0} \\
a_{1}
\end{array}\right\}, \\
\varphi_{k x}^{\prime}(x)=d_{0}+d_{1} x=\left[\begin{array}{ll}
1 & x
\end{array}\right]\left\{\begin{array}{l}
d_{0} \\
d_{1}
\end{array}\right\} .
\end{gathered}
$$

Strypo poslinkių $y^{\prime}$ ir $z^{\prime}$ ašių kryptimis aproksimuojančios funkcijos yra kubiniai polinomai:

$$
\begin{aligned}
& u_{k y}^{\prime}(x)=b_{0}+b_{1} x+b_{2} x^{2}+b_{3} x^{3}=\left[\begin{array}{llll}
1 & x & x^{2} & x^{3}
\end{array}\right]\left\{\begin{array}{l}
b_{0} \\
b_{1} \\
b_{2} \\
b_{3}
\end{array}\right\}, \\
& u_{k z}^{\prime}(x)=c_{0}+c_{1} x+c_{2} x^{2}+c_{3} x^{3}=\left[\begin{array}{llll}
1 & x & x^{2} & x^{3}
\end{array}\right]\left\{\begin{array}{l}
c_{0} \\
c_{1} \\
c_{2} \\
c_{3}
\end{array}\right\} .
\end{aligned}
$$

Surašius (2.14)-(2.15) lygtis i bendrą lygčių sistemą ir užrašius matricine forma gaunama: 


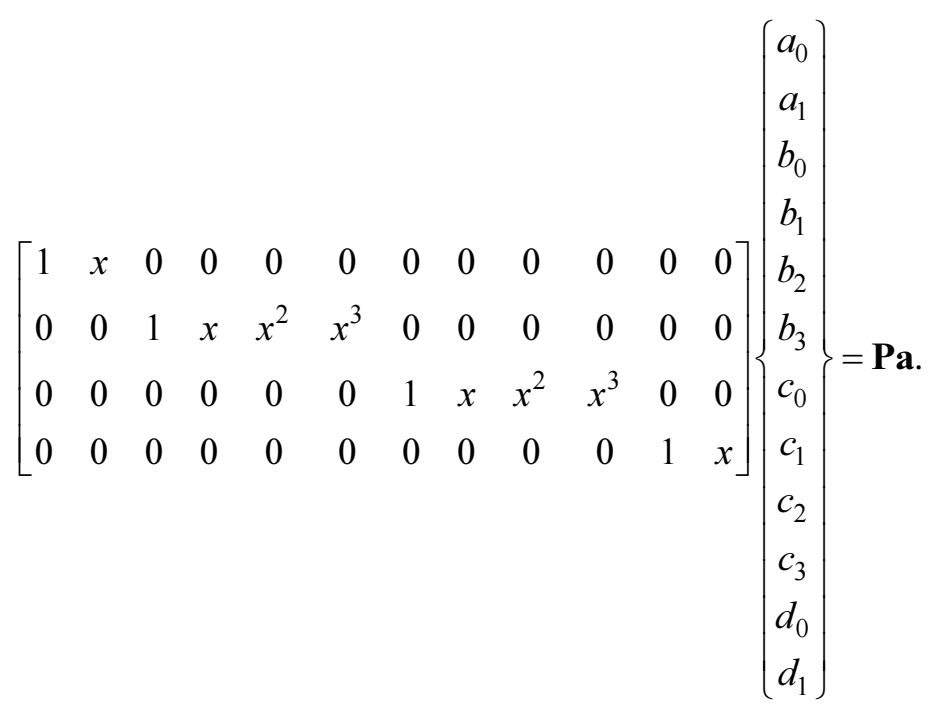

Šių (2.14)-(2.15) poslinkių funkcijų interpoliacijos taškai yra mazginiai taškai $x=0$ ir $x=l_{k}$. Šiuose taškuose yra duotos ne tik įlinkių funkcijos (2.16)(2.17), bet ir šių funkcijų pirmosios išvestinès (kampiniai poslinkiai):

$$
\begin{aligned}
& \varphi_{k y}^{\prime}(x)=-\frac{d u_{k y}^{\prime}(x)}{d x}=-\left(b_{1}+b_{2} x+b_{3} x^{2}\right), \\
& \varphi_{k z}^{\prime}(x)=-\frac{d u_{k z}^{\prime}(x)}{d x}=-\left(c_{1}+c_{2} x+c_{3} x^{2}\right) .
\end{aligned}
$$

Irašę i funkcijas (2.14)-(2.17) ir (2.19)-(2.20) elemento mazginių tašku koordinates, gauname tokia lygčių sistemą:

$$
\left.\begin{array}{l}
u_{k x}^{\prime}(x=0)=u_{k 1}^{\prime}=a_{0}, u_{k y}^{\prime}(x=0)=u_{k 2}^{\prime}=b_{0}, \\
u_{k z}^{\prime}(x=0)=u_{k 3}^{\prime}=c_{0}, \varphi_{k x}^{\prime}(x=0)=u_{k 4}^{\prime}=d_{0}, \\
\varphi_{k y}^{\prime}(x=0)=u_{k 5}^{\prime}=-b_{1}, \varphi_{k z}^{\prime}(x=0)=u_{k 6}^{\prime}=-c_{1}, \\
u_{k x}^{\prime}\left(x=l_{k}\right)=u_{k 7}^{\prime}=a_{0}+a_{1} l_{k}, u_{k y}^{\prime}\left(x=l_{k}\right)=u_{k 8}^{\prime}=b_{0}+b_{1} l_{k}+b_{2} l_{k}^{2}+b_{3} l_{k}^{3}, \\
u_{k z}^{\prime}\left(x=l_{k}\right)=u_{k 9}^{\prime}=c_{0}+c_{1} l_{k}+c_{2} l_{k}^{2}+c_{3} l_{k}^{3}, \varphi_{k x}^{\prime}\left(x=l_{k}\right)=u_{k 10}^{\prime}=d_{0}+d_{1} l_{k}, \\
\varphi_{k y}^{\prime}\left(x=l_{k}\right)=u_{k 11}^{\prime}=-b_{1}-2 b_{2} l_{k}-3 b_{3} l_{k}^{2}, \\
\varphi_{k z}^{\prime}\left(x=l_{k}\right)=u_{k 12}^{\prime}=-c_{1}-2 c_{2} l_{k}-3 c_{3} l_{k}^{2} .
\end{array}\right\}
$$

Lygybių sistema (2.21) matricine-vektorine forma yra užrašoma taip: 


$$
\left\{\begin{array}{l}
u_{k 1}^{\prime} \\
u_{k 2}^{\prime} \\
u_{k 3}^{\prime} \\
u_{k 4}^{\prime} \\
u_{k 5}^{\prime} \\
u_{k 6}^{\prime} \\
u_{k 7}^{\prime} \\
u_{k 8}^{\prime} \\
u_{k 9}^{\prime} \\
u_{k 10}^{\prime} \\
u_{k 11}^{\prime} \\
u_{k 12}^{\prime}
\end{array}\right\}=\left[\begin{array}{cccccccccccc}
1 & 0 & 0 & 0 & 0 & 0 & 0 & 0 & 0 & 0 & 0 & 0 \\
0 & 0 & 1 & 0 & 0 & 0 & 0 & 0 & 0 & 0 & 0 & 0 \\
0 & 0 & 0 & 0 & 0 & 0 & 1 & 0 & 0 & 0 & 0 & 0 \\
0 & 0 & 0 & 0 & 0 & 0 & 0 & 0 & 0 & 0 & 1 & 0 \\
0 & 0 & 0 & -1 & 0 & 0 & 0 & 0 & 0 & 0 & 0 & 0 \\
0 & 0 & 0 & 0 & 0 & 0 & 0 & -1 & 0 & 0 & 0 & 0 \\
1 & l_{k} & 0 & 0 & 0 & 0 & 0 & 0 & 0 & 0 & 0 & 0 \\
0 & 0 & 1 & l_{k} & l_{k}^{2} & l_{k}^{3} & 0 & 0 & 0 & 0 & 0 & 0 \\
0 & 0 & 0 & 0 & 0 & 0 & 1 & l_{k} & l_{k}^{2} & l_{k}^{3} & 0 & 0 \\
0 & 0 & 0 & 0 & 0 & 0 & 0 & 0 & 0 & 0 & 1 & l_{k} \\
0 & 0 & 0 & -1 & -2 l_{k} & -3 l_{k}^{2} & 0 & 0 & 0 & 0 & 0 & 0 \\
0 & 0 & 0 & 0 & 0 & 0 & 0 & -1 & -2 l_{k} & -3 l_{k}^{2} & 0 & 0
\end{array}\right]\left\{\begin{array}{c}
a_{0} \\
a_{1} \\
b_{0} \\
b_{1} \\
b_{2} \\
b_{3} \\
c_{0} \\
c_{1} \\
c_{2} \\
c_{3} \\
d_{0} \\
d_{1}
\end{array}\right\},
$$

arba trumpiau:

$$
\mathbf{u}_{k}^{\prime}=\mathbf{C a} .
$$

Išsprendę šią lygčių sistemą, gauname polinomų koeficientų išraiškas per elemento mazginių taškų poslinkius:

$$
\begin{aligned}
& a_{0}=u_{k 1}^{\prime}, a_{1}=-\frac{1}{l} u_{k 1}^{\prime}+\frac{1}{l} u_{k 7}^{\prime}, b_{0}=u_{k 2}^{\prime}, b_{1}=-u_{k 5}^{\prime}, \\
& b_{2}=-\frac{3}{l^{2}} u_{k 2}^{\prime}+\frac{2}{l} u_{k 5}^{\prime}+\frac{3}{l^{2}} u_{k 8}^{\prime}+\frac{1}{l} u_{k 11}^{\prime}, b_{3}=\frac{2}{l^{3}} u_{k 2}^{\prime}-\frac{1}{l^{2}} u_{k 5}^{\prime}-\frac{2}{l^{3}} u_{k 8}^{\prime}-\frac{1}{l^{2}} u_{k 11}^{\prime}, \\
& c_{0}=u_{k 3}^{\prime}, c_{1}=-u_{k 6}^{\prime}, c_{2}=-\frac{3}{l^{2}} u_{k 3}^{\prime}+\frac{2}{l} u_{k 6}^{\prime}+\frac{3}{l^{2}} u_{k 9}^{\prime}+\frac{1}{l} u_{k 12}^{\prime}, \\
& c_{3}=\frac{2}{l^{3}} u_{k 3}^{\prime}-\frac{1}{l^{2}} u_{k 6}^{\prime}-\frac{2}{l^{3}} u_{k 9}^{\prime}-\frac{1}{l^{2}} u_{k 12}^{\prime}, d_{0}=u_{k 4}^{\prime}, d_{1}=-\frac{1}{l} u_{k 4}^{\prime}+\frac{1}{l} u_{k 10}^{\prime} .
\end{aligned}
$$

Užrašę matricine forma, gauname: 


$$
\left\{\begin{array}{l}
a_{0} \\
a_{1} \\
b_{0} \\
b_{1} \\
b_{2} \\
b_{3} \\
c_{0} \\
c_{1} \\
c_{2} \\
c_{3} \\
d_{0} \\
d_{1}
\end{array}\right\}=\left[\begin{array}{cccccccccccc}
1 & 0 & 0 & 0 & 0 & 0 & 0 & 0 & 0 & 0 & 0 & 0 \\
-\frac{1}{l_{k}} & 0 & 0 & 0 & 0 & 0 & \frac{1}{l_{k}} & 0 & 0 & 0 & 0 & 0 \\
0 & 1 & 0 & 0 & 0 & 0 & 0 & 0 & 0 & 0 & 0 & 0 \\
0 & 0 & 0 & 0 & -1 & 0 & 0 & 0 & 0 & 0 & 0 & 0 \\
0 & -\frac{3}{l_{k}^{2}} & 0 & 0 & \frac{2}{l_{k}} & 0 & 0 & \frac{3}{l_{k}^{2}} & 0 & 0 & \frac{1}{l_{k}} & 0 \\
0 & \frac{2}{l_{k}^{3}} & 0 & 0 & -\frac{1}{l_{k}^{2}} & 0 & 0 & -\frac{2}{l_{k}^{3}} & 0 & 0 & -\frac{1}{l_{k}^{2}} & 0 \\
0 & 0 & 1 & 0 & 0 & 0 & 0 & 0 & 0 & 0 & 0 & 0 \\
0 & 0 & 0 & 0 & 0 & -1 & 0 & 0 & 0 & 0 & 0 & 0 \\
0 & 0 & -\frac{3}{l_{k}^{2}} & 0 & 0 & \frac{2}{l_{k}} & 0 & 0 & \frac{3}{l_{k}^{2}} & 0 & 0 & \frac{1}{l_{k}} \\
0 & 0 & \frac{2}{l_{k}^{3}} & 0 & 0 & -\frac{1}{l_{k}^{2}} & 0 & 0 & -\frac{2}{l_{k}^{3}} & 0 & 0 & -\frac{1}{l_{k}^{2}} \\
0 & 0 & 0 & 1 & 0 & 0 & 0 & 0 & 0 & 0 & 0 & 0 \\
0 & 0 & 0 & -\frac{1}{l_{k}} & 0 & 0 & 0 & 0 & 0 & \frac{1}{l_{k}} & 0 & 0
\end{array}\right]\left\{\begin{array}{c}
u_{k 1}^{\prime} \\
u_{k 2}^{\prime} \\
u_{k 3}^{\prime} \\
u_{k 4}^{\prime} \\
u_{k 5}^{\prime} \\
u_{k 6}^{\prime} \\
u_{k 7}^{\prime} \\
u_{k 8}^{\prime} \\
u_{k 9}^{\prime} \\
u_{k 10}^{\prime} \\
u_{k 11}^{\prime} \\
u_{k 12}^{\prime}
\end{array}\right\} .
$$

Šias polinomų koeficientų išraiškas įstatę i (2.14)-(2.17) gauname elemento bet kurio taško linijinio poslinkio, sukimo ar ịlinkio išraišką per šio elemento mazginių taškų poslinkius:

$$
\begin{gathered}
u_{k x}^{\prime}(x)=u_{k 1}^{\prime}+\left(-\frac{1}{l_{k}} u_{k 1}^{\prime}+\frac{1}{l_{k}} u_{k 7}^{\prime}\right) x, \\
\varphi_{k x}^{\prime}(x)=u_{k 4}^{\prime}+\left(-\frac{1}{l_{k}} u_{k 4}^{\prime}+\frac{1}{l_{k}} u_{k 10}^{\prime}\right) x, \\
u_{k y}^{\prime}(x)=u_{k 2}^{\prime}+\left(-u_{k 5}^{\prime}\right) x+\left(-\frac{3}{l_{k}^{2}} u_{k 2}^{\prime}+\frac{2}{l_{k}} u_{k 5}^{\prime}+\frac{3}{l_{k}^{2}} u_{k 8}^{\prime}+\frac{1}{l_{k}} u_{k 11}^{\prime}\right) x^{2}+ \\
\left(\frac{2}{l_{k}^{3}} u_{k 2}^{\prime}-\frac{1}{l_{k}^{2}} u_{k 5}^{\prime}-\frac{2}{l_{k}^{3}} u_{k 8}^{\prime}-\frac{1}{l_{k}^{2}} u_{k 11}^{\prime}\right) x^{3},
\end{gathered}
$$




$$
\begin{gathered}
u_{k z}^{\prime}(x)=u_{k 3}^{\prime}+\left(-u_{k 6}^{\prime}\right) x+\left(-\frac{3}{l_{k}^{2}} u_{k 3}^{\prime}+\frac{2}{l_{k}} u_{k 6}^{\prime}+\frac{3}{l_{k}^{2}} u_{k 9}^{\prime}+\frac{1}{l_{k}} u_{k 12}^{\prime}\right) x^{2}+ \\
\left(\frac{2}{l_{k}^{3}} u_{k 3}^{\prime}-\frac{1}{l_{k}^{2}} u_{k 6}^{\prime}-\frac{2}{l_{k}^{3}} u_{k 9}^{\prime}-\frac{1}{l_{k}^{2}} u_{k 12}^{\prime}\right) x^{3} .
\end{gathered}
$$

Sutraukus panašius narius gauname:

$$
\begin{gathered}
u_{k x}^{\prime}(x)=\left(1-\frac{x}{l_{k}}\right) u_{k 1}^{\prime}+\frac{x}{l_{k}} u_{k 7}^{\prime}, \\
\varphi_{k x}^{\prime}(x)=\left(1-\frac{x}{l_{k}}\right) u_{k 4}^{\prime}+\frac{x}{l_{k}} u_{k 10}^{\prime}, \\
u_{k y}^{\prime}(x)=\left(\frac{2 x^{3}}{l_{k}^{3}}-\frac{3 x^{2}}{l_{k}^{2}}+1\right) u_{k 2}^{\prime}+\left(-\frac{3 x^{3}}{l_{k}^{3}}+\frac{2 x^{2}}{l_{k}}-x\right) u_{k 5}^{\prime}+ \\
u_{k z}^{\prime}(x)=\left(\frac{2 x^{3}}{l_{k}^{3}}+\frac{3 x^{2}}{l_{k}^{2}}\right) u_{k 8}^{\prime}+\left(-\frac{x^{3}}{l_{k}^{2}}+\frac{x^{2}}{l_{k}}\right) u_{k 11}^{\prime}, \\
\left(-\frac{2 x^{2}}{l_{k}^{2}}+1\right) u_{k 3}^{\prime}+\left(-\frac{3 x^{3}}{l_{k}^{3}}+\frac{2 x^{2}}{l_{k}}-x\right) u_{k 6}^{\prime}+ \\
\left.l_{k}^{2}\right) u_{k 9}^{\prime}+\left(-\frac{x^{3}}{l_{k}^{2}}+\frac{x^{2}}{l_{k}}\right) u_{k 12}^{\prime} .
\end{gathered}
$$

Tokiu būdu, elemento bet kurio taško poslinkių vektorius $\mathbf{u}_{k}(x)=\left[\begin{array}{llll}u_{x}^{\prime}(x) & u_{y}^{\prime}(x) & u_{z}^{\prime}(x) & \varphi_{x}^{\prime}(x)\end{array}\right]^{T}$, ivertinus aukščiau vartotus žymėjimus, yra išreiškiamas elemento mazginiais poslinkiais ir užrašomas taip:

$$
\mathbf{u}_{k}(x)=\mathbf{P C}^{-1} \mathbf{u}_{k}^{\prime}=\mathbf{N}_{k}(x) \mathbf{u}_{k}^{\prime},
$$

čia $\mathbf{N}_{k}(x)=\left[\begin{array}{ll}N_{1} & N_{2}\end{array}\right]$, kur

$$
N_{1}=\left[\begin{array}{cccccc}
N_{1}(x) & 0 & 0 & 0 & 0 & 0 \\
0 & N_{3}(x) & 0 & 0 & 0 & N_{4}(x) \\
0 & 0 & N_{3}(x) & 0 & N_{5}(x) & 0 \\
0 & 0 & 0 & N_{1}(x) & 0 & 0
\end{array}\right],
$$




$$
N_{2}=\left[\begin{array}{cccccc}
N_{2}(x) & 0 & 0 & 0 & 0 & 0 \\
0 & N_{6}(x) & 0 & 0 & 0 & N_{7}(x) \\
0 & 0 & N_{6}(x) & 0 & N_{8}(x) & 0 \\
0 & 0 & 0 & N_{2}(x) & 0 & 0
\end{array}\right],
$$

yra vadinama elemento formos funkcijų matrica, kurios nariai yra Ermito polinomai:

$$
\left.\begin{array}{l}
N_{1}(x)=1-\frac{x}{l_{k}}, N_{2}(x)=\frac{x}{l_{k}}, \\
N_{3}(x)=1-\frac{3}{l_{k}^{2}} x^{2}+\frac{2}{l_{k}^{3}} x^{3}, N_{4}(x)=x-\frac{2}{l_{k}} x^{2}+\frac{1}{l_{k}^{2}} x^{3}, \\
N_{5}(x)=-x+\frac{2}{l_{k}} x^{2}-\frac{1}{l_{k}^{2}} x^{3}, N_{6}(x)=\frac{3}{l_{k}^{2}} x^{2}-\frac{2}{l_{k}^{3}} x^{3}, \\
N_{7}(x)=-\frac{1}{l_{k}} x^{2}+\frac{1}{l_{k}^{2}} x^{3}, N_{8}(x)=\frac{1}{l_{k}} x^{2}-\frac{1}{l_{k}^{2}} x^{3} .
\end{array}\right\}
$$

\subsubsection{Deformacijų aproksimacija mazginiais poslinkiais}

Nagrinejamas palyginti didelių poslinkiu atvejis, kai maksimaliu ilinkių ir skerspjūvio charakteringų matmenų (skerspjūvio aukščio $h$ bei pločio $b$ ) santykiai tenkina šias ribas: $1 / 5 \leq u_{\max } / h \leq 1 / 5$. Tuomet ryšys tarp deformacijų ir poslinkių yra netiesinis. Monografijoje (Čyras et al. 2004) yra išvestos šio ryšio formulès bet kokios formos erdviniam elementui kreivalinijineje ortogonalioje koordinačių sistemoje. Šios formulès susieja elemento viduriniojo paviršiaus deformacijas su šio paviršiaus taškų poslinkiais. Jas galima panaudoti ir rèminès konstrukcijos elementui, prièmus, kad kreivalinijinès koordinatès sutampa su stačiakampe Dekarto koordinačių sistema, o jas lydinčiosios pirmosios kvadratinès formos koeficientu funkcijos yra lygios 1 bei kreivių spinduliai yra lygūs begalybei. Tuomet strypo ašies išilginè ir skersinè deformacijos:

$$
\Delta_{x}=\frac{\partial u_{x}^{\prime}(x)}{\partial x}+\frac{1}{2}\left(\frac{\partial u_{y}^{\prime}(x)}{\partial x}\right)^{2}+\frac{1}{2}\left(\frac{\partial u_{z}^{\prime}(x)}{\partial x}\right)^{2}, \quad \theta_{x}=\frac{\partial \varphi_{x}^{\prime}(x)}{\partial x}
$$

o kreiviai

$$
\kappa_{y}=\frac{\partial^{2} u_{z}^{\prime}(x)}{\partial x^{2}}, \kappa_{z}=\frac{\partial^{2} u_{y}^{\prime}(x)}{\partial x^{2}} .
$$


Elemento skerspjūvio bet kurio taško suminè išilginè ir skersinè deformacijos užrašomos taip:

$$
\begin{gathered}
\boldsymbol{\varepsilon}_{k}(x)=\Delta_{x}-y \kappa_{y}-z \kappa_{z}= \\
\frac{\partial u_{x}^{\prime}(x)}{\partial x}+\frac{1}{2}\left(\frac{\partial u_{y}^{\prime}(x)}{\partial x}\right)^{2}+\frac{1}{2}\left(\frac{\partial u_{z}^{\prime}(x)}{\partial x}\right)^{2}-y \frac{\partial^{2} u_{z}^{\prime}(x)}{\partial x^{2}}-z \frac{\partial^{2} u_{y}^{\prime}(x)}{\partial x^{2}}, \\
\gamma_{k}(x)=y \theta_{x}+z \theta_{x}=y \frac{\partial \varphi_{x}^{\prime}(x)}{\partial x}+z \frac{\partial \varphi_{x}^{\prime}(x)}{\partial x},
\end{gathered}
$$

čia $y$ ir $z$-taško atstumai nuo strypo neutralios ašies.

Paprastumo dėlei, nagrinejjamas strypinis elementas, kurio skerspjūvio geometriniai parametrai - plotis $b$, aukštis $h$ ir ilgis $l$. Tuomet jo vidinių jègų vektorius (2.10) yra užrašomas taip:

$$
\begin{array}{r}
\boldsymbol{\Psi}_{k}\left(\mathbf{u}_{k}^{\prime}\right)=\int_{-b / 2}^{b / 2} \int_{-h / 2}^{h / 2} \int_{0}^{l}\left\{\frac{\partial \boldsymbol{\varepsilon}_{k}(x)}{\partial \mathbf{u}_{k}^{\prime}}\right\}^{T} \boldsymbol{\sigma}_{k}(x) d x d y d z+ \\
\int_{-b / 2-h / 2}^{b / 2} \int_{-h / 2}^{l}\left\{\frac{\partial \boldsymbol{\gamma}_{k}(x)}{\partial \mathbf{u}_{k}^{\prime}}\right\}^{T} \boldsymbol{\tau}_{k}(x) d x d y d z .
\end{array}
$$

Vidinių jègų vektorių (2.35) išreiškiame elemento mazgu poslinkiais i deformacijų išraiškas (2.33-2.34) ịrašius poslinkių aproksimacijų funkcijas (2.31). Gauname deformacijų funkcijas, išreikštas poslinkiais:

$$
\begin{gathered}
\boldsymbol{\varepsilon}_{k}(x)=\mathbf{C}_{0} \mathbf{u}_{k}^{\prime}+\frac{1}{2} \mathbf{u}_{k}^{\prime}{ }^{T} \mathbf{C}_{6}(x) \mathbf{u}_{k}^{\prime}+\frac{1}{2} \mathbf{u}_{k}^{\prime}{ }^{T} \mathbf{C}_{7}(x) \mathbf{u}_{k}^{\prime}- \\
y \mathbf{C}_{5}(x) \mathbf{u}_{k}^{\prime}-z \mathbf{C}_{4}(x) \mathbf{u}_{k}^{\prime}, \\
\gamma_{k}(x)=z \mathbf{C}_{3} \mathbf{u}_{k}^{\prime}+y \mathbf{C}_{3} \mathbf{u}_{k}^{\prime},
\end{gathered}
$$

čia $\quad \mathbf{C}_{0}, \quad \mathbf{C}_{3}, \quad \mathbf{C}_{4}(x)=\frac{\partial \mathbf{C}_{1}(x)}{\partial x}, \quad \mathbf{C}_{5}(x)=\frac{\partial \mathbf{C}_{2}(x)}{\partial x}, \quad \mathbf{C}_{6}(x)=\mathbf{C}_{1}(x)^{T} \mathbf{C}_{1}(x)$, $\mathbf{C}_{7}(x)=\mathbf{C}_{2}(x)^{T} \mathbf{C}_{2}(x)$ yra koeficientu matricos, gaunamos diferencijuojant elemento formos funkcijų matricos $\mathbf{N}_{k}(x)$ atitinkamas eilutes:

$$
\mathbf{C}_{0}=\left[\begin{array}{llllllllllll}
-\frac{1}{l_{k}} & 0 & 0 & 0 & 0 & 0 & \frac{1}{l_{k}} & 0 & 0 & 0 & 0 & 0
\end{array}\right],
$$




$$
\begin{aligned}
& \mathbf{C}_{1}(x)=\left[\begin{array}{lllllll}
0 & \frac{6 x^{2}}{l_{k}^{3}}-\frac{6 x}{l_{k}^{2}} & 0 & 0 & 0 & \frac{3 x^{2}}{l_{k}^{2}}-\frac{4 x}{l_{k}}+1
\end{array}\right. \\
& \left.0 \frac{6 x}{l_{k}^{2}}-\frac{6 x^{2}}{l_{k}^{3}} \quad 0 \quad 00 \quad 0 \quad \frac{3 x^{2}}{l_{k}^{2}}-\frac{2 x}{l_{k}}\right], \\
& \mathbf{C}_{2}(x)=\left[\begin{array}{llllll}
0 & 0 & \frac{6 x^{2}}{l_{k}^{3}}-\frac{6 x}{l_{k}^{2}} & 0 & \frac{4 x}{l_{k}}-\frac{3 x^{2}}{l_{k}^{2}}-1 & 0
\end{array}\right.
\end{aligned}
$$

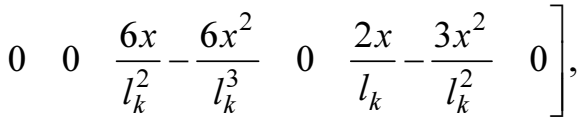

$$
\begin{aligned}
& \mathbf{C}_{3}=\left[\begin{array}{llllllllllll}
0 & 0 & 0 & -\frac{1}{l_{k}} & 0 & 0 & 0 & 0 & 0 & \frac{1}{l_{k}} & 0 & 0
\end{array}\right] \text {. }
\end{aligned}
$$

\subsubsection{Elemento tangentinè standumo matrica}

İrašius (2.36-2.37) išraiškas ị (2.35), elemento vidinių jègu vektorius yra išreiškiamas tokiu būdu:

$$
\begin{aligned}
& \boldsymbol{\Psi}_{k}(u)=\int_{-b / 2}^{b / 2} \int_{-h / 2}^{h / 2} \int_{0}^{l} \mathbf{C}_{0}{ }^{T} \boldsymbol{\sigma}_{k}(x) d x d y d z+ \\
& \int_{-b / 2}^{b / 2} \int_{h / 2}^{h / 2} \int_{0}^{l} \mathbf{C}_{6}(x)^{T} \mathbf{u}_{k}^{\prime} \boldsymbol{\sigma}_{k}(x) d x d y d z+\int_{-b / 2}^{b / 2} \int_{h / 2}^{h / 2} \int_{0}^{l} \mathbf{C}_{7}(x)^{T} \mathbf{u}_{k}^{\prime} \boldsymbol{\sigma}_{k}(x) d x d y d z- \\
& \int_{-b / 2}^{b / 2} \int_{-h / 2}^{h / 2} \int_{0}^{l} y \mathbf{C}_{5}(x)^{T} \boldsymbol{\sigma}_{k}(x) d x d y d z-\int_{-b / 2}^{b / 2} \int_{-h / 2}^{h / 2} \int_{0}^{l} z \mathbf{C}_{4}(x)^{T} \boldsymbol{\sigma}_{k}(x) d x d y d z+ \\
& \int_{-b / 2}^{b / 2} \int_{-h / 2}^{h / 2} \int_{0}^{l} z \mathbf{C}_{3}(x)^{T} \boldsymbol{\tau}_{k}(x) d x d y d z+\int_{-b / 2}^{h / 2} \int_{-h / 2}^{h} \int_{0}^{l} y \mathbf{C}_{3}(x)^{T} \boldsymbol{\tau}_{k}(x) d x d y d z .
\end{aligned}
$$

Panaudojus gautą vidinių jègų vektorių, tangentinè standumo matrica (2.11) yra tokia: 


$$
\begin{aligned}
& \mathbf{k}_{\tau}\left(\mathbf{u}_{k}^{\prime}\right)=\frac{\partial \boldsymbol{\Psi}_{k}\left(\mathbf{u}_{k}^{\prime}\right)}{\partial \mathbf{u}_{k}^{\prime}}= \\
& \int_{-b / 2}^{b / 2} \int_{-h / 2}^{h / 2} \int_{0}^{l} \mathbf{C}_{0}^{T} \frac{\partial \boldsymbol{\sigma}_{k}(x)}{\partial \mathbf{u}_{k}^{\prime}} d x d y d z+\int_{-b / 2}^{b / 2} \int_{-h / 2}^{h / 2} \int_{0}^{l} \mathbf{C}_{6}(x)^{T} \boldsymbol{\sigma}_{k}(x) d x d y d z+ \\
& \int_{-b / 2}^{b / 2} \int_{-h / 2}^{h / 2} \int_{0}^{l} \mathbf{C}_{6}(x)^{T} \mathbf{u}_{k}^{\prime} \frac{\partial \boldsymbol{\sigma}_{k}(x)}{\partial \mathbf{u}_{k}^{\prime}} d x d y d z+\int_{-b / 2}^{b / 2} \int_{-h / 2}^{h / 2} \int_{0}^{l} \mathbf{C}_{7}(x)^{T} \boldsymbol{\sigma}_{k}(x) d x d y d z+ \\
& \int_{-b / 2}^{b / 2} \int_{-h / 2}^{h / 2} \int_{0}^{l} \mathbf{C}_{7}(x)^{T} \mathbf{u}_{k}^{\prime} \frac{\partial \boldsymbol{\sigma}_{k}(x)}{\partial \mathbf{u}_{k}^{\prime}} d x d y d z-\int_{-b / 2}^{h / 2} \int_{-h / 2}^{l} \int_{-b / 2}^{l} y \mathbf{C}_{5}(x)^{T} \frac{\partial \boldsymbol{\sigma}_{k}(x)}{\partial / 2} d x d y d z- \\
& \int_{b / 2}^{h / 2} \int_{-h / 2}^{l} \int_{0}^{\prime} z \mathbf{C}_{4}(x)^{T} \frac{\partial \boldsymbol{\sigma}_{k}(x)}{\partial / 2} d x d y d z+\int_{-h / 2}^{l} \int_{k}^{l} z \mathbf{u}_{3}^{\prime}(x)^{T} \frac{\partial \boldsymbol{\tau}_{k}(x)}{\partial \mathbf{u}_{k}^{\prime}} d x d y d z+ \\
& \int_{-h / 2} \int_{0} \mathbf{C}_{3}(x)^{T} \frac{\partial \boldsymbol{\tau}_{k}(x)}{\partial \mathbf{u}_{k}^{\prime}} d x d y d z .
\end{aligned}
$$

I Huko dèsnį $\boldsymbol{\sigma}_{k}(x)=E \boldsymbol{\varepsilon}_{k}(x)$ ir $\boldsymbol{\tau}_{k}(x)=G \gamma_{k}(x)$ įrašę deformacijų išraiškas (2.362.37), gauname itempius mazginiais poslinkiais:

$$
\begin{gathered}
\boldsymbol{\sigma}_{k}(x)=E \mathbf{C}_{0} \mathbf{u}_{k}^{\prime}+\frac{1}{2} E \mathbf{u}_{k}^{\prime T} \mathbf{C}_{6}(x) \mathbf{u}_{k}^{\prime}+\frac{1}{2} E \mathbf{u}_{k}^{\prime T} \mathbf{C}_{7}(x) \mathbf{u}_{k}^{\prime}- \\
y E \mathbf{C}_{5}(x) \mathbf{u}_{k}^{\prime}-z E \mathbf{C}_{4}(x) \mathbf{u}_{k}^{\prime}, \\
\boldsymbol{\tau}_{k}(x)=z G \mathbf{C}_{3} \mathbf{u}_{k}^{\prime}+y G \mathbf{C}_{3} \mathbf{u}_{k}^{\prime},
\end{gathered}
$$

čia $E$ - medžiagos tamprumo modulis; $G$-medžiagos šlyties modulis.

Skaičiuojamos įtempių funkcijų (2.40-2.41) išvestines:

$$
\begin{gathered}
\frac{\partial \boldsymbol{\sigma}_{k}(x)}{\partial \mathbf{u}_{k}^{\prime}}=E\left(\mathbf{C}_{0}+{ }_{\mathbf{u}_{k}{ }^{T}} \mathbf{C}_{6}(x)+\mathbf{u}_{k}^{\prime T} \mathbf{C}_{7}(x)-y \mathbf{C}_{5}(x)-z \mathbf{C}_{4}(x)\right), \\
\frac{\partial \boldsymbol{\tau}_{k}(x)}{\partial \mathbf{u}_{k}^{\prime}}=G\left(z \mathbf{C}_{3}+y \mathbf{C}_{3}\right) .
\end{gathered}
$$

Itempius (2.40-2.41) ir jų išvestines (2.42-2.43) ịrašę i (2.38) ir atlikę diferencijavimą, gauname elemento tangentinę standumo matricą:

$$
\mathbf{k}_{\tau}^{\prime}=\mathbf{k}_{e}^{\prime}+\mathbf{k}_{g}^{\prime}+\mathbf{k}_{u}^{\prime},
$$

čia 


$$
\begin{gathered}
\mathbf{k}_{e}^{\prime}=E \int_{-b / 2}^{b / 2} \int_{-h / 20}^{h / 2} \int_{0}^{l}\left(\mathbf{C}_{0}{ }^{T} \mathbf{C}_{0}-z \mathbf{C}_{0}{ }^{T} \mathbf{C}_{4}(x)-y \mathbf{C}_{0}{ }^{T} \mathbf{C}_{5}(x)-\right. \\
z \mathbf{C}_{4}(x)^{T} \mathbf{C}_{0}+z^{2} \mathbf{C}_{4}(x)^{T} \mathbf{C}_{4}(x)+z y \mathbf{C}_{4}(x)^{T} \mathbf{C}_{5}(x)- \\
\left.y \mathbf{C}_{5}(x)^{T} \mathbf{C}_{0}+z y \mathbf{C}_{5}(x)^{T} \mathbf{C}_{4}(x)+y^{2} \mathbf{C}_{5}(x)^{T} \mathbf{C}_{5}(x)\right) d x d y d z+ \\
G \int_{-b / 2}^{b / 2} \int_{-h / 2}^{h / 2} \int_{0}^{l}\left(z^{2} \mathbf{C}_{3}{ }^{T} \mathbf{C}_{3}-z y \mathbf{C}_{3}{ }^{T} \mathbf{C}_{3}+y^{2} \mathbf{C}_{3}{ }^{T} \mathbf{C}_{3}\right) d x d y d z
\end{gathered}
$$

yra elemento mažų poslinkių standumo matrica;

$$
\mathbf{k}_{g}^{\prime}=\int_{-b / 2}^{b / 2} \int_{-h / 2}^{h / 2} \int_{0}^{l}\left(\mathbf{C}_{6}(x)^{T}+\mathbf{C}_{7}(x)^{T}\right) \boldsymbol{\sigma}_{k}(x) d x d y d z
$$

yra geometrinè standumo matrica;

$$
\begin{aligned}
& \mathbf{k}_{u}^{\prime}=E \int_{-b / 2}^{b / 2} \int_{-h / 2}^{h / 2} \int_{0}^{l}\left(0,5 \mathbf{C}_{0}^{T} \mathbf{u}_{k}^{\prime T} \mathbf{C}_{6}(x)+0,5 \mathbf{C}_{0}^{T} \mathbf{u}_{k}^{\prime T} \mathbf{C}_{7}(x)+\right. \\
& \mathbf{C}_{6}(x)^{T} \mathbf{u}_{k}^{\prime} \mathbf{C}_{0}+0,5 \mathbf{C}_{6}(x)^{T} \mathbf{u}_{k}^{\prime} \mathbf{u}_{k}^{\prime T} \mathbf{C}_{6}(x)+ \\
& 0,5 \mathbf{C}_{6}(x)^{T} \mathbf{u}_{k}^{\prime} \mathbf{u}_{k}^{\prime T} \mathbf{C}_{7}(x)-z \mathbf{C}_{6}(x)^{T} \mathbf{u}_{k}^{\prime} \mathbf{C}_{9}(x)- \\
& y \mathbf{C}_{6}(x)^{T} \mathbf{u}_{k}^{\prime} \mathbf{C}_{5}(x)+\mathbf{C}_{7}(x)^{T} \mathbf{u}_{k}^{\prime} \mathbf{C}_{0}+ \\
& 0,5 \mathbf{C}_{7}(x)^{T} \mathbf{u}_{k}^{\prime} \mathbf{u}_{k}^{\prime T} \mathbf{C}_{6}(x)+0,5 \mathbf{C}_{7}(x)^{T} \mathbf{u}_{k}^{\prime} \mathbf{u}_{k}^{\prime}{ }^{T} \mathbf{C}_{7}(x)- \\
& z \mathbf{C}_{7}(x)^{T} \mathbf{u}_{k}^{\prime} \mathbf{C}_{4}(x)-y \mathbf{C}_{7}(x)^{T} \mathbf{u}_{k}^{\prime} \mathbf{C}_{5}(x)- \\
& 0,5 z \mathbf{C}_{4}(x)^{T} \mathbf{u}_{k}^{\prime T} \mathbf{C}_{6}(x)-0,5 z \mathbf{C}_{4}(x)^{T} \mathbf{u}_{k}^{\prime T} \mathbf{C}_{7}(x)- \\
& \left.0,5 y \mathbf{C}_{5}(x)^{T} \mathbf{u}_{k}^{\prime T} \mathbf{C}_{6}(x)-0,5 y \mathbf{C}_{5}(x)^{T} \mathbf{u}_{k}^{\prime T} \mathbf{C}_{7}(x)\right) d x d y d z
\end{aligned}
$$

yra pradiniu poslinkių standumo matrica.

I (2.46) įrašius (2.40-2.41) išraiškas, gauname geometrinę standumo matricą išreikštą mazginiais poslinkiais: 


$$
\begin{gathered}
\mathbf{k}_{g}^{\prime}=E \int_{-b / 2}^{b / 2} \int_{-h / 2}^{h / 2} \int_{0}^{l}\left(\mathbf{C}_{6}(x)^{T} \mathbf{C}_{0} \mathbf{u}_{k}^{\prime}+0,5 \mathbf{C}_{6}(x)^{T} \mathbf{u}_{k}^{\prime} \mathbf{C}_{6}(x) \mathbf{u}_{k}^{\prime}+\right. \\
0,5 \mathbf{C}_{6}(x)^{T} \mathbf{u}_{k}^{\prime T} \mathbf{C}_{7}(x) \mathbf{u}_{k}^{\prime}-z \mathbf{C}_{6}(x)^{T} \mathbf{C}_{4}(x) \mathbf{u}_{k}^{\prime}- \\
y \mathbf{C}_{6}(x)^{T} \mathbf{C}_{5}(x) \mathbf{u}_{k}^{\prime}+\mathbf{C}_{7}(x)^{T} \mathbf{C}_{0} \mathbf{u}_{k}^{\prime}+ \\
0,5 \mathbf{C}_{7}(x)^{T} \mathbf{u}_{k}^{\prime T} \mathbf{C}_{6}(x) \mathbf{u}_{k}^{\prime}+0,5 \mathbf{C}_{7}(x)^{T} \mathbf{u}_{k}^{\prime T} \mathbf{C}_{7}(x) \mathbf{u}_{k}^{\prime}- \\
\left.z \mathbf{C}_{7}(x)^{T} \mathbf{C}_{4}(x) \mathbf{u}_{k}^{\prime}-y \mathbf{C}_{7}(x)^{T} \mathbf{C}_{5}(x) \mathbf{u}_{k}^{\prime}\right) d x d y d z
\end{gathered}
$$

Gautos išraiškos dešiniosios pusès pirmasis ir šeštasis nariai sudaro pastoviają geometrinès standumo matricos, kurią nulemia tempimo gniuždymo itempiai, dali. Antrasis, trečiasis, septintasis ir aštuntasis - kintamają, apibrèžiančią lenkimo įtempių įtaką elemento standumui, o ketvirtasis, penktasis, devintasis ir dešimtasis nariai - atlikus algebrinius veiksmus ir yra lygūs nuliui.

Erdvinio rèminio elemento tangentinès standumo matricos simbolinė išraiška buvo nustatyta panaudojus kompiuterinio matematinio skaičiavimo komplekso MATLAB simbolinių skaičiavimų paprogramę Symbolic Math Toolbox. Komandinès bylos tekstas, sudarytas pagal MATLAB programavimo kalbos dèsningumus, yra pateiktas priede A.

Transformacija iš lokaliujų komponentų i globaliuosius yra atliekama ịprastu keliu. Tam tikslui lokaliojoje koordinačių sistemoje sudarome elemento krypčiu kosinusu matricą $\mathbf{T}_{a b}$ ir gauname elemento tangentinę standumo matricą globaliųjų ašių sistemoje:

$$
\mathbf{k}_{\tau}=\mathbf{T}_{a b}^{T} \cdot \mathbf{k}_{\tau}^{\prime} \cdot \mathbf{T}_{a b},
$$

čia

$$
\mathbf{T}_{a b}=\left[\begin{array}{ccc}
\cos \alpha & \cos \beta & \cos \gamma \\
\frac{-\cos \alpha \cos \beta}{\sqrt{\cos \alpha^{2}+\cos \gamma^{2}}} & \sqrt{\cos \alpha^{2}+\cos \gamma^{2}} & \frac{-\cos \beta \cos \gamma}{\sqrt{\cos \alpha^{2}+\cos \gamma^{2}}} \\
\frac{-\cos \gamma}{\sqrt{\cos \alpha^{2}+\cos \gamma^{2}}} & 0 & \frac{\cos \alpha}{\sqrt{\cos \alpha^{2}+\cos \gamma^{2}}}
\end{array}\right]
$$

yra krypčių kosinusų matrica bet kuriam erdviniam baigtiniam elementui (Saouma V. E. 2000); 


$$
\mathbf{T}_{a b}=\left[\begin{array}{ccc}
0 & \cos \beta & 0 \\
-\cos \beta & 0 & 0 \\
0 & 0 & 1
\end{array}\right]
$$

yra krypčių kosinusų matrica griežtai vertikaliam erdviniam baigtiniam elementui (Saouma V. E. 2000). Ši matrica yra taikoma vertikaliems elementams pirmos skaičiavimų iteracijos metu; $\alpha, \beta$ ir $\gamma$-kampai tarp lokalios $x^{\prime}$ ašies ir globaliujų $x, y$ ir $z$ ašiu (2.2 pav. b).

Iš atskirų baigtinių elementų tangentinių standumo matricu formuojama kvazidiagonalinè matrica $\overline{\mathbf{K}}_{\tau}$ ir apskaičiuojama visos konstrukcijos tangentinè standumo matrica:

$$
\mathbf{K}_{\tau}=\mathbf{H}^{T} \overline{\mathbf{K}}_{\tau} \mathbf{H},
$$

čia H yra konstrukcijos baigtinių elementų poslinkių ir visos konstrukcijos poslinkiu darnos matrica, nusakanti kokie konstrukcijos baigtinių elementu poslinkiai atitinka visos konstrukcijos globaliuosius poslinkius.

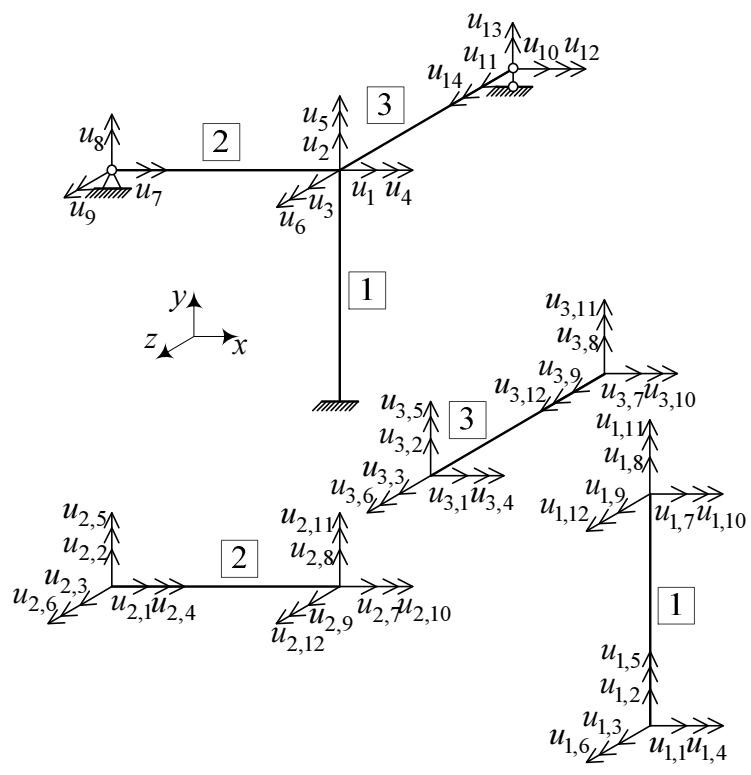

2.3 pav. Lokaliujų rẻmo elementụ poslinkių schema bei rėminės konstrukcijos poslinkiụ schema globaliojoje koordinačiu sistemoje

Fig. 2.3. Local frame elements displacements schema and frame construction displacements in the global coordinate system 


\section{1 lentelè. Poslinkiu ryšio matrica $\mathbf{H}$}

Table 2.1. Displacements consistency matrix $\mathbf{H}$

\begin{tabular}{|c|c|c|c|c|c|c|c|c|c|c|c|c|c|c|}
\hline & $u_{1}$ & $u_{2}$ & $\mathrm{u}_{3}$ & $u_{4}$ & $u_{5}$ & $u_{6}$ & $u_{7}$ & $u_{8}$ & $u_{9}$ & $u_{10}$ & $u_{11}$ & $u_{12}$ & $u_{13}$ & $u_{14}$ \\
\hline$u_{1,1}$ & 0 & 0 & 0 & 0 & 0 & 0 & 0 & 0 & 0 & 0 & 0 & 0 & 0 & 0 \\
\hline$u_{1,2}$ & 0 & 0 & 0 & 0 & 0 & 0 & 0 & 0 & 0 & 0 & 0 & 0 & 0 & 0 \\
\hline$u_{1,3}$ & 0 & 0 & 0 & 0 & 0 & 0 & 0 & 0 & 0 & 0 & 0 & 0 & 0 & 0 \\
\hline$u_{1,4}$ & 0 & 0 & 0 & 0 & 0 & 0 & 0 & 0 & 0 & 0 & 0 & 0 & 0 & 0 \\
\hline$u_{1,5}$ & 0 & 0 & 0 & 0 & 0 & 0 & 0 & 0 & 0 & 0 & 0 & 0 & 0 & 0 \\
\hline$u_{1,6}$ & 0 & 0 & 0 & 0 & 0 & 0 & 0 & 0 & 0 & 0 & 0 & 0 & 0 & 0 \\
\hline$u_{1,7}$ & 1 & 0 & 0 & 0 & 0 & 0 & 0 & 0 & 0 & 0 & 0 & 0 & 0 & 0 \\
\hline$u_{1,8}$ & 0 & 1 & 0 & 0 & 0 & 0 & 0 & 0 & 0 & 0 & 0 & 0 & 0 & 0 \\
\hline$u_{1,9}$ & 0 & 0 & 1 & 0 & 0 & 0 & 0 & 0 & 0 & 0 & 0 & 0 & 0 & 0 \\
\hline$u_{1,10}$ & 0 & 0 & 0 & 1 & 0 & 0 & 0 & 0 & 0 & 0 & 0 & 0 & 0 & 0 \\
\hline$u_{1,11}$ & 0 & 0 & 0 & 0 & 1 & 0 & 0 & 0 & 0 & 0 & 0 & 0 & 0 & 0 \\
\hline$u_{1,12}$ & 0 & 0 & 0 & 0 & 0 & 1 & 0 & 0 & 0 & 0 & 0 & 0 & 0 & 0 \\
\hline$u_{2,1}$ & 0 & 0 & 0 & 0 & 0 & 0 & 0 & 0 & 0 & 0 & 0 & 0 & 0 & 0 \\
\hline$u_{2,2}$ & 0 & 0 & 0 & 0 & 0 & 0 & 0 & 0 & 0 & 0 & 0 & 0 & 0 & 0 \\
\hline$u_{2,3}$ & 0 & 0 & 0 & 0 & 0 & 0 & 0 & 0 & 0 & 0 & 0 & 0 & 0 & 0 \\
\hline$u_{2,4}$ & 0 & 0 & 0 & 0 & 0 & 0 & 1 & 0 & 0 & 0 & 0 & 0 & 0 & 0 \\
\hline$u_{2,5}$ & 0 & 0 & 0 & 0 & 0 & 0 & 0 & 1 & 0 & 0 & 0 & 0 & 0 & 0 \\
\hline$u 2,6$ & 0 & 0 & 0 & 0 & 0 & 0 & 0 & 0 & 1 & 0 & 0 & 0 & 0 & 0 \\
\hline$u 2,7$ & 1 & 0 & 0 & 0 & 0 & 0 & 0 & 0 & 0 & 0 & 0 & 0 & 0 & 0 \\
\hline$u_{2,8}$ & 0 & 1 & 0 & 0 & 0 & 0 & 0 & 0 & 0 & 0 & 0 & 0 & 0 & 0 \\
\hline$u_{2,9}$ & 0 & 0 & 1 & 0 & 0 & 0 & 0 & 0 & 0 & 0 & 0 & 0 & 0 & 0 \\
\hline$u_{2,10}$ & 0 & 0 & 0 & 1 & 0 & 0 & 0 & 0 & 0 & 0 & 0 & 0 & 0 & 0 \\
\hline$u_{2,11}$ & 0 & 0 & 0 & 0 & 1 & 0 & 0 & 0 & 0 & 0 & 0 & 0 & 0 & 0 \\
\hline$u_{2,12}$ & 0 & 0 & 0 & 0 & 0 & 1 & 0 & 0 & 0 & 0 & 0 & 0 & 0 & 0 \\
\hline$u_{3,1}$ & 1 & 0 & 0 & 0 & 0 & 0 & 0 & 0 & 0 & 0 & 0 & 0 & 0 & 0 \\
\hline$u_{3,2}$ & 0 & 1 & 0 & 0 & 0 & 0 & 0 & 0 & 0 & 0 & 0 & 0 & 0 & 0 \\
\hline$u_{3,3}$ & 0 & 0 & 1 & 0 & 0 & 0 & 0 & 0 & 0 & 0 & 0 & 0 & 0 & 0 \\
\hline$u_{3,4}$ & 0 & 0 & 0 & 1 & 0 & 0 & 0 & 0 & 0 & 0 & 0 & 0 & 0 & 0 \\
\hline$u_{3,5}$ & 0 & 0 & 0 & 0 & 1 & 0 & 0 & 0 & 0 & 0 & 0 & 0 & 0 & 0 \\
\hline$u_{3,6}$ & 0 & 0 & 0 & 0 & 0 & 1 & 0 & 0 & 0 & 0 & 0 & 0 & 0 & 0 \\
\hline$u_{3,7}$ & 0 & 0 & 0 & 0 & 0 & 0 & 0 & 0 & 0 & 1 & 0 & 0 & 0 & 0 \\
\hline$u_{3,8}$ & 0 & 0 & 0 & 0 & 0 & 0 & 0 & 0 & 0 & 0 & 0 & 0 & 0 & 0 \\
\hline$u_{3,9}$ & 0 & 0 & 0 & 0 & 0 & 0 & 0 & 0 & 0 & 0 & 1 & 0 & 0 & 0 \\
\hline$u_{3,10}$ & 0 & 0 & 0 & 0 & 0 & 0 & 0 & 0 & 0 & 0 & 0 & 1 & 0 & 0 \\
\hline$u_{3,11}$ & 0 & 0 & 0 & 0 & 0 & 0 & 0 & 0 & 0 & 0 & 0 & 0 & 1 & 0 \\
\hline$u_{3,12}$ & 0 & 0 & 0 & 0 & 0 & 0 & 0 & 0 & 0 & 0 & 0 & 0 & 0 & 1 \\
\hline
\end{tabular}

Siekiant geriau suprasti matricos $\mathbf{H}$ struktūrą, sudaroma diskrečiu rèmo elementų lokaliujų poslinkių schema (2.3 pav.), kurioje lokalieji poslinkiai yra pažymèti $u_{1,1}, u_{1,2}, \ldots, u_{3,12}$ (pirmasis skaičius indekse žymi elemento numerį). Jei nagrinejjamo elemento mazginio taško lokalusis poslinkis, pavyzdžiui $u_{1,8}$ sutampa su diskretinio modelio mazgo globaliuoju poslinkiu, šiuo atveju $u_{2}$, tai matricos $\mathbf{H}$ 8 eilutès 2 stulpelyje įrašomas 1 , o kituose -0 . Nulinè eilutè reiškia, kad elemento 
mazgo taško poslinkis atitinkama kryptimi yra suvaržytas (negalimas). Taip logiškai svarstant, gauta poslinkių ryšio matrica yra pateikta 2.1 lentelejje. Jos viršuje pažymėti globalieji poslinkiai $\mathbf{u}=\left[\begin{array}{llll}u_{1} & u_{2} & \ldots & u_{12}\end{array}\right]^{T}$, o lentelès kairejje pusèje - elementų mazgų taškų lokalieji poslinkiai globaliojoje koordinačių sistemoje $\overline{\mathbf{u}}=\left[\begin{array}{llll}u_{1,1} & u_{1,2} & \ldots & u_{3,12}\end{array}\right]^{T}$.

Visos konstrukcijos tangentine standumo matrica $\mathbf{K}_{\tau}$ yra inkorporuojama $i$ prieaugiais užrašytas pusiausvyros lygtis:

$$
\mathbf{K}_{\tau} \Delta \mathbf{u}=\Delta \mathbf{F},
$$

čia $\Delta \mathbf{F}$ ir $\Delta \mathbf{u}$ yra visos konstrukcijos mazginès apkrovos prieaugiu ir globaliujų poslinkių prieaugių vektoriai.

\subsubsection{Ekvivalentinių apkrovos jègų apskaičiavimas}

Dažniausiai apkrovos yra paskirstytos per visą baigtinio elemento ilgi (2.4 pav. a). Darbe nagrinejjamas erdvinis elementas, kurio veikiančiosios jègos ar galimi poslinkiai yra sukoncentruoti mazguose (2.2 pav.), tad paskirstytosios apkrovos turi būti pakeistos paprastesnèmis, jas atstojančiomis mazginèmis jègomis (2.4 pav. b). Śių mazginiu jègų reikšmès yra apskaičiuojamos iš darbų lygybès. Iš tamprumo teorijos (Atkočiūnas, J., Nagevičius, J. 2004) fizikinių dèsnių žinoma, kad konstrukcijai esant pusiausvyroje vidinių jègų darbas turi būti lygus išorinių jègų darbui:

$$
V_{k, F}^{\prime}=V_{k, p}^{\prime} .
$$
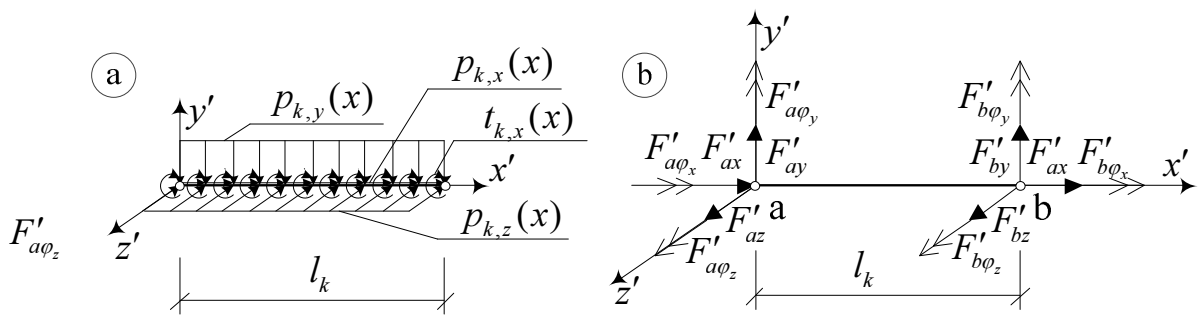

2.4 pav. Erdvinio rèminio elemento apkrovos: a) paskirstytosios apkrovos;

b) ekvivalentinès mazginès jègos

Fig. 2.4. The three-dimensional frame element loads: a) member, distributed loads;

b) equivalent nodal forces

Šioje lygybejje vidinių jègų darbą atlieka ekvivalentiškos mazginès jègos:

$$
V_{k, F}^{\prime}=\mathbf{u}_{k}^{\prime T} \mathbf{F}_{k}^{\prime},
$$


čia $\mathbf{u}_{k}$ yra $k$-ojo baigtinio elemento mazginių poslinkių vektorius globaliojoje koordinačiu sistemoje; $\mathbf{F}_{k}$, yra $k$-ojo baigtinio elemento mazginių jègų vektorius globaliojoje koordinačių sistemoje.

Išorinių jègų darbą lygtyje (2.52) aprašo paskirstytujų apkrovų darbas, aprašomas formule:

$$
V_{k, p}=\int_{0}^{l_{k}} \mathbf{u}_{k}(x)^{T} \mathbf{p}_{k}(x) d x,
$$

čia $\mathbf{u}_{k}(x)$ yra $k$-ojo baigtinio elemento bet kurio taško linijinių poslinkių vektorius; $\mathbf{p}_{k}(x)=\left[\begin{array}{llll}p_{k, x}(x) & p_{k, y}(x) & p_{k, z}(x) & t_{k, x}(x)\end{array}\right]^{T}$ yra $k$-ojo baigtinio elemento veikiančiujų išorinių paskirstytujų apkrovų vektorius;

Žinant, kad $\mathbf{u}_{k}(x)=\mathbf{N}_{k}(x) \mathbf{u}_{k}$ lygti (2.54) galima užrašyti:

$$
V_{k, p}=\mathbf{u}_{k}^{T} \int_{0}^{l_{k}} \mathbf{N}_{k}(x)^{T} \mathbf{p}_{k}(x) d x .
$$

Gautas jègų išraiškas įrašome i (2.52) išraišką ir gauname:

$$
\mathbf{u}_{k}^{T} \mathbf{F}_{k}=\mathbf{u}_{k}^{T} \int_{0}^{l_{k}} \mathbf{N}_{k}(x)^{T} \mathbf{p}_{k}(x) d x .
$$

Sutraukus panašius narius, gauname:

$$
\mathbf{F}_{k}=\int_{0}^{l_{k}} \mathbf{N}_{k}(x)^{T} \mathbf{p}_{k}(x) d x .
$$

Laikoma, kad išorinès paskirstytosios apkrovos išlieka pastovios per visą elemento ilgị, t. y. nèra priklausomos nuo $x$. Tokiu būdu vektorinę funkciją $\mathbf{p}_{k}(x)$ galima užrašyti:

$$
\mathbf{p}_{k}(x)=\left\{\begin{array}{c}
p_{k, x}(x) \\
p_{k, y}(x) \\
p_{k, z}(x) \\
t_{k, x}(x)
\end{array}\right\}=\left\{\begin{array}{c}
p_{k, x} \\
p_{k, y} \\
p_{k, z} \\
t_{k, x}
\end{array}\right\} .
$$

Irašius (2.58), (2.31) ir (2.32) išraiškas i (2.57) bei atlikus atitinkamus skaičiavimus, gaunamos ekvivalentinių mazginių jègų reikšmés: 


$$
\begin{array}{r}
\mathbf{p}_{k}(x)=\left[\begin{array}{lllllll}
F_{k, 1} & F_{k, 2} F_{k, 3} F_{k, 4} F_{k, 5} & F_{k, 6} F_{k, 7} & F_{k, 8} F_{k, 9} F_{k, 10} F_{k, 11} F_{k, 12}
\end{array}\right]^{T}= \\
{\left[\begin{array}{rrrrrrr}
\frac{p_{k, x} l_{k}}{2} & \frac{p_{k, \mathrm{y}} l_{k}}{2} & \frac{p_{k, \mathrm{z}} l_{k}}{2} & \frac{t_{k, x} l_{k}}{2} & -\frac{p_{k, z} l_{k}^{2}}{12} & \frac{p_{k, \mathrm{y}} l_{k}^{2}}{12} & \\
\frac{p_{k, x} l_{k}}{2} & \frac{p_{k, \mathrm{y}} l_{k}}{2} & \frac{p_{k, \mathrm{z}} l_{k}}{2} & \frac{t_{k, x} l_{k}}{2} & \frac{p_{k, z} l_{k}^{2}}{12} & -\frac{p_{k, \mathrm{y}} l_{k}^{2}}{12}
\end{array}\right]^{T} .}
\end{array}
$$

Išdèstytasis ekvivalentiškų mazginių jègų skaičiavimas buvo atliktas pritaikius kompiuterinio matematinio MATLAB skaičiavimo komplekso simbolinių skaičiavimų paprogramę Symbolic Math Toolbox. Komandinès bylos tekstas, sudarytas pagal MATLAB programavimo kalbos dėsningumus, yra pateiktas priede B.

\subsection{Tangentinio standumo metodo skaitmeninis realizavimas}

Literatūroje yra pateikiami ịvairūs netiesinių lygčiu sistemos (2.1) sprendimo metodai (Polyanin and Manzhirov 2007; Амосов et al. 2008.). Disertaciniame darbe naudojamas Newton-Raphson iteracinis apkrovos kontrolès metodas (Belytscho and Liu 2000; Zienkiewicz et al. 2005), kadangi apkrovos-poslinkių kreivè yra iškila funkcija. Be to, verta pažymèti, kad konstrukcijos optimizacija atliekama nepasiekus visiško plastiškojo suirimo. Dèl šios priežasties tangentiné standumo matrica negali būti nuline: $\mathbf{K}_{\imath} \neq 0$. Taip pat skaitmeniniais eksperimentais nustatyta, kad Newton-Raphson metodu galutinis rezultatas pasiekiamas per du ar tris apkrovos žingsnius.

Aptarkime Newton-Raphson metodą, kurio principinė schema yra parodyta 2.5 paveiksle. Ten pat yra pateikti konstrukcijos netiesinę elgseną charakterizuojantys dydžiai. Taikant ši metodą, apkrovos vektorius $\mathbf{F}$ yra skaidomas ị dalis ir kiekvieno žingsnio metu didinamas tam tikru prieaugiu $\Delta F_{v}$ (2.5 pav.). Kiekvieno apkrovos prieaugio žingsnyje $v$ daromos iteracijos $i$ tam, kad eliminuoti nesubalansuotąsias jègas $F_{c, v}^{i}$. Jos atsiranda dèl nesubalansuotu mazgo vidinių ir išorinių jègų (2.5 pav.):

$$
\mathbf{F}_{c, v}^{i}=\mathbf{F}_{v+1}-\mathbf{F}_{s, v}^{i},
$$

čia $\mathbf{F}_{c, v}$ - nesubalansuotų mazginių jègų vektorius $v$-tojo žingsnio $i$-tosios iteracijos gale; $\mathbf{F}_{v+1}-$ mazgo išorinių jègų vektorius $v$-tojo žingsnio gale; $\mathbf{F}_{s, v}^{i}-$ mazginių vidinių jègų vektorius $v$-tojo žingsnio $i$-tosios iteracijos gale. 


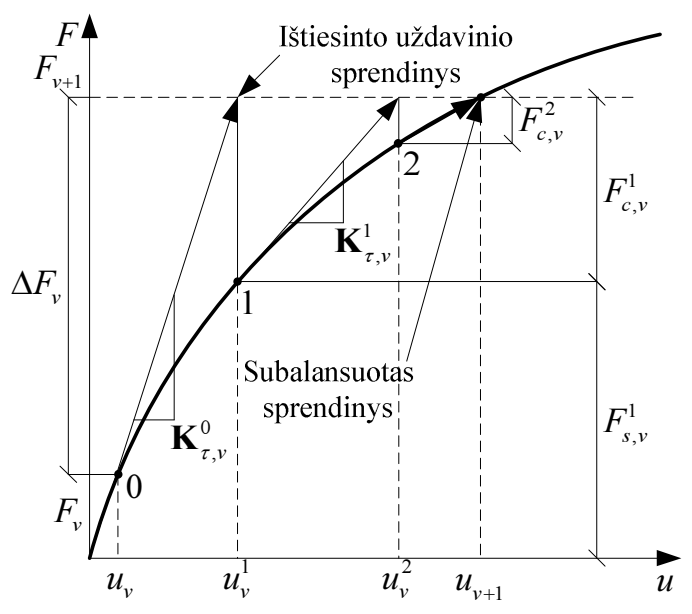

2.5 pav. Newton-Raphson metodas

Fig. 2.5. The Newton-Raphson method

Šios paklaidos atsiranda ištiesinant uždavinị, t. y. standumo matrica formuojama panaudojant prieš tai buvusios iteracijos metu nustatytas mazgu poslinkių reikšmes.

Žemiau pateikta vieno apkrovos prieaugio (žingsnio) iteracinio skaičiavimo metodika.

Tarkime, kad globaliujų poslinkių vektorius $\mathbf{u}_{v}$ ir apkrovos lygis $\mathbf{F}_{v}$ nagrinejamo žingsnio $v$ pradžioje yra žinomi. Tuomet $v$-tojo apkrovos žingsnio metu skaičiavimai atliekami vykdant tokias operacijas:

1. Nustatomas naujo apkrovos lygio vektorius:

$$
\mathbf{F}_{v+1}=\mathbf{F}_{v}+\Delta \mathbf{F},
$$

čia $\Delta \mathbf{F}$ - yra apkrovos prieaugių vektorius.

2. Suformuojame $v$ apkrovimo žingsnio $i$-tosios iteracijos konstrukcijos tangentinę standumo matricą $\mathbf{K}_{\tau, v}^{i}$ (iš paskirų elementų tangentinių standumo matricu (2.50)) ir nustatome jos determinantą. Jeigu determinantas yra neigiamas, konstatuojame, kad konstrukcija yra geometriškai judri ir baigiame skaičiavimus. Jeigu determinantas yra teigiamas, sudarome prieaugines pusiausvyros lygtis (2.51) nesubalansuotų mazginių jègų $\mathbf{F}_{c, v}^{i}$ skaičiavimui (pažymime, kad pirmoje iteracijoje $\mathbf{F}_{c, v}^{i=1}=\Delta \mathbf{F}$ ):

$$
\mathbf{K}_{\tau, v}^{i} \Delta \mathbf{u}_{v}^{i}=\mathbf{F}_{c, v}^{i} .
$$

3. Sprendžiame sudarytą tiesinių lygčių sistemą ir gauname vykdomojo $v$ žingsnio $i$-tos iteracijos globaliųų poslinkių prieaugių vektorių: 


$$
\Delta \mathbf{u}_{v}^{i}=\left(\mathbf{K}_{\tau, v}^{i}\right)^{-1} \mathbf{F}_{c, v}^{i} .
$$

4. Skaičiuojame naujus globaliuosius mazgų poslinkius. Tam tikslui prie nesubalansuotų mazginių jègų gautujų poslinkių prieaugių (2.63) pridedame ankstesneje iteracijoje gautąsias globaliąsias poslinkių reikšmes:

$$
\mathbf{u}_{v}^{i}=\Delta \mathbf{u}_{v}^{i}+\mathbf{u}_{v}^{i-1} .
$$

5. Skaičiuojame naujas mazgų koordinates pagal tokią formulę:

$$
\mathbf{x}_{v}^{i}=\mathbf{x}_{v}^{i-1}+\mathbf{u}_{v}^{i} .
$$

Toliau skaičiuojame naujus elementų ašies pasvirimo krypčių kosinusus ir elementų ilgius $l_{a b, n}$, sudarome elementų koordinačių transformavimo matricas $\mathbf{T}_{a b, x}^{\prime i}$ ir fiktyviają pusiausvyros lygčių matricą $\overline{\mathbf{A}}_{v}^{i}$ iš paskirų baigtinių elementu pusiausvyros lygčių matricų $\mathbf{A}_{a b, v}^{\prime i}$. Tam tikslui užrašome elemento, parodyto 2.2 paveiksle, apkrovos prieaugio $v$-ojo žingsnio $i$-tosios iteracijos pusiausvyros lygtis tarp elemento galų ir lokaliujų mazginių jègų:

$$
\mathbf{A}_{a b, v}^{\prime i} \cdot \mathbf{S}_{a b}=\mathbf{F}_{k}^{\prime},
$$

čia pusiausvyros lygčių koeficientų matrica yra:

$$
\mathbf{A}_{a b, v}^{\prime i}=\left[\begin{array}{cccccc}
-1 & 0 & 0 & 0 & 0 & 0 \\
0 & 1 / l_{a b, n} & 0 & 0 & 0 & 1 / l_{a b, n} \\
0 & 0 & -1 / l_{a b, n} & 0 & -1 / l_{a b, n} & 0 \\
0 & 0 & 0 & 1 & 0 & 0 \\
0 & 0 & 1 & 0 & 0 & 0 \\
0 & 1 & 0 & 0 & 0 & 0 \\
1 & 0 & 0 & 0 & 0 & 0 \\
0 & -1 / l_{a b, n} & 0 & 0 & 0 & -1 / l_{a b, n} \\
0 & 0 & 1 / l_{a b, n} & 0 & 1 / l_{a b, n} & 0 \\
0 & 0 & 0 & -1 & 0 & 0 \\
0 & 0 & 0 & 0 & 1 & 0 \\
0 & 0 & 0 & 0 & 0 & 1
\end{array}\right] .
$$

Ši matrica gaunama užrašant pusiausvyros sąlygas erdvinio rèminio elemento (2.6 pav.) mazguose. 


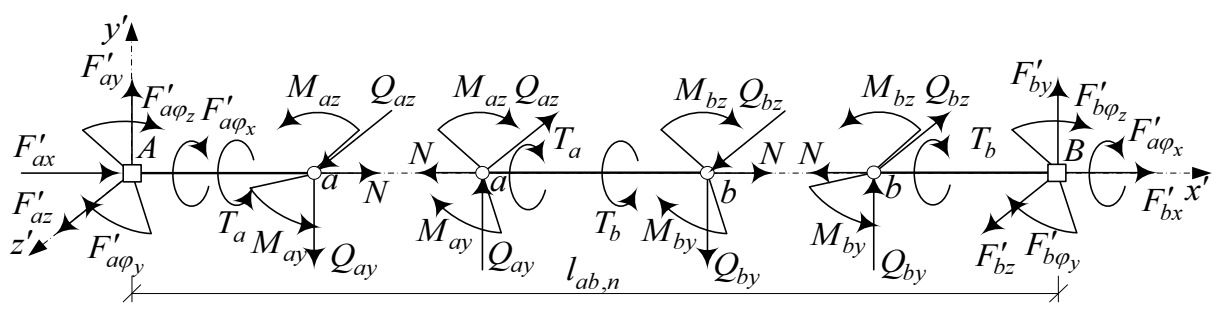

2.6 pav. Erdvinio rẻminio elemento jègos ir ịrąžos

Fig. 2.6. The three-dimensional frame element forces and internal stresses

Pusiausvyros sąlygos mazge „A“:

$\sum F_{A, x}=0 ; \quad F_{a x}^{\prime}+N=0 ; \quad-N=F_{a x}^{\prime} ;$

$\sum F_{A, y}=0 ; \quad F_{a y}^{\prime}+Q_{a y}=0 ; \quad-Q_{a y}=F_{a y}^{\prime} ; \quad M_{a z} / l_{a b, n}+M_{b z} / l_{a b, n}=F_{a y}^{\prime} ;$

$\sum F_{A, z}=0 ; \quad F_{a z}^{\prime}-Q_{a z}=0 ; \quad Q_{a z}=F_{a z}^{\prime} ; \quad-M_{a y} / l_{a b, n}-M_{b y} / l_{a b, n}=F_{a z}^{\prime} ;$

$\sum M_{A, x}=0 ; \quad F_{a \varphi_{x}}^{\prime}-T_{a}=0 ; \quad T_{a}=F_{a \varphi_{x}}^{\prime} ;$

$\sum M_{A, y}=0 ; \quad F_{a \varphi_{y}}^{\prime}-M_{a y}=0 ; \quad M_{a y}=F_{a \varphi_{y}}^{\prime} ;$

$\sum M_{A, z}=0 ; \quad F_{a \varphi_{z}}^{\prime}-M_{a z}=0 ; \quad M_{a z}=F_{a \varphi_{z}}^{\prime}$.

Pusiausvyros sąlygos mazge „B“:

$\sum F_{B, x}=0 ; \quad F_{b x}^{\prime}-N=0 ; \quad N=F_{b x}^{\prime} ;$

$\sum F_{B, y}=0 ; \quad F_{b y}^{\prime}-Q_{b y}=0 ; \quad Q_{b y}=F_{b y}^{\prime} ; \quad-M_{a z} / l_{a b, n}-M_{b z} / l_{a b, n}=F_{b y}^{\prime} ;$

$\sum F_{B, z}=0 ; \quad F_{b z}^{\prime}+Q_{b z}=0 ; \quad-Q_{b z}=F_{b z}^{\prime} ; \quad M_{a y} / l_{a b, n}+M_{b y} / l_{a b, n}=F_{b z}^{\prime} ;$

$\sum M_{B, x}=0 ; \quad F_{b \varphi_{x}}^{\prime}+T_{b}=0 ; \quad-T_{b}=F_{b \varphi_{x}}^{\prime} ;$

$\sum M_{B, y}=0 ; \quad F_{b \varphi_{y}}^{\prime}-M_{b y}=0 ; \quad M_{b y}=F_{b \varphi_{y}}^{\prime} ;$

$\sum M_{B, z}=0 ; \quad F_{b \varphi_{z}}^{\prime}-M_{b z}=0 ; \quad M_{b z}=F_{b \varphi_{z}}^{\prime}$.

Užrašius šias pusiausvyros sąlygas, gaunama (2.66) išraiška matricine forma.

6. Nustatome elementų vidinių jègų prieaugių dydžius ir sudarome elemento globaliujų vidinių jègų prieaugių vektorius:

$$
\Delta \mathbf{S}_{a b}^{i}=\mathbf{k}_{v}^{\prime i}\left(\mathbf{A}_{a b, v}^{\prime i}\right)^{T} \mathbf{T}_{a b, x}^{\prime i} \Delta \mathbf{u}_{a b, v}^{i},
$$

su $v$-ojo žingsnio $i$-tosios iteracijos elemento įrąžų ir deformacijų fizinių lygčių matrica: 


$$
\mathbf{k}_{v}^{\prime i}=\left[\begin{array}{cccccc}
\frac{E A_{a b}}{l_{a b, n}} & 0 & 0 & 0 & 0 & 0 \\
0 & \frac{4 E I_{y, a b}}{l_{a b, n}} & 0 & 0 & 0 & \frac{2 E I_{y, a b}}{l_{a b, n}} \\
0 & 0 & \frac{4 E I_{z, a b}}{l_{a b, n}} & 0 & \frac{2 E I_{z, a b}}{l_{a b, n}} & 0 \\
0 & 0 & 0 & \frac{G I_{t, a b}}{l_{a b, n}} & 0 & 0 \\
0 & 0 & \frac{2 E I_{z, a b}}{l_{a b, n}} & 0 & \frac{4 E I_{z, a b}}{l_{a b, n}} & 0 \\
0 & \frac{2 E I_{y, a b}}{l_{a b, n}} & 0 & 0 & 0 & \frac{4 E I_{y, a b}}{l_{a b, n}}
\end{array}\right] .
$$

Sudarome globaliujų vidinių jęgų prieaugių vektorių: $\Delta \mathbf{S}_{v}^{i}=\left[\begin{array}{llll}\Delta \mathbf{S}_{1, v}^{i} & \Delta \mathbf{S}_{2, v}^{i} & \ldots \Delta \mathbf{S}_{a b, v}^{i} & \ldots \Delta \mathbf{S}_{s, v}^{i}\end{array}\right]^{T}$.

7. Skaičiuojame konstrukcijos elementų vidinių mazginių jègu prieaugius: $\Delta \overline{\mathbf{F}}_{s, v}^{i}=\overline{\mathbf{A}}_{v}^{i} \Delta \mathbf{S}_{v}^{i}$.

8. Nustatome globalujji mazginių jègų prieaugių vektorių:

$$
\Delta \mathbf{F}_{s, v}^{i}=\mathbf{H}^{T} \Delta \overline{\mathbf{F}}_{s, v}^{i} .
$$

9. Skaičiuojame $v$ apkrovos prieaugio žingsnio $i$-tosios iteracijos pabaigos sumines elementų mazgines jègas ir ịrąžas:

$$
\begin{aligned}
\mathbf{F}_{s, v}^{i} & =\mathbf{F}_{s, v}^{i-1}+\Delta \mathbf{F}_{s, v}^{i}, \\
\mathbf{S}_{v}^{i} & =\mathbf{S}_{v}^{i-1}+\Delta \mathbf{S}_{v}^{i} .
\end{aligned}
$$

10. Skaičiuojame nesubalansuotas (kompensacines) mazgines jègas (2.60).

11. Tikriname pasirinkto tikslumo konvergencijos sąlygą:

$$
\mathbf{F}_{c, v}^{i}-\mathbf{F}_{c, v}^{i-1} \leq \mathrm{eps} ?
$$

Jei ši sąlyga netenkinama, toliau vykdome žingsnini skaičiavimą, t. y. kartojame skaičiavimus aprašytus $1-10$ operacijose.

Iteracinis ciklas baigiamas, kai nesubalansuotų jègų vektorius $\mathbf{F}_{c, v}$ yra labai mažas arba, kai tenkinamas pasirinktas tikslumas $\mathbf{F}_{c, v}^{i}-\mathbf{F}_{c, v}^{i-1} \leq$ eps? Po to 
gauname konstrukcijos deformuoto būvio visus reikalingus parametrus ir pusiausvyros lygčių koeficientų matricą $\mathbf{A}_{n}=\mathbf{H} \overline{\mathbf{A}}_{v}$, atitinkančią tam tikrą apkrovos lygi $\mathbf{F}$.

Aukščiau aprašytas skaičiavimas algoritmo pavidalu yra pateiktas 2.7 paveiksle.

\subsection{Liekamujjụ ịrąžụ analizès uždavinys}

Tampriosios plastinès sistemos liekamujjų ịrąžų tikrajam būviui rasti (Čyras 1983; Atkočiūnas et al. 2010) naudojamas ekstreminis energinis principas: iš visų statiškai leistinu liekamųu įrąžų vektoriu sistemoje, kuri visiškai plastiškai nesuiro, tikrasis yra tas, kuris atitinka minimalią papildomo deformavimo energiją.

Papildomo deformavimo energija yra išreiškiama liekamuju įąžų kvadratine forma (Atkočiūnas et al. 2010):

$$
U_{r}=\frac{1}{2} \mathbf{S}_{r}^{T} \mathbf{D}_{n} \mathbf{S}_{r} .
$$

Svarbu pažymèti, kad kai konstrukciją veikia vienkartinė apkrova, statiškai leistinų liekamuju irą̧žų vektorius yra toks, kuris atitinka statikos lygtis:

$$
\mathbf{A}_{n} \mathbf{S}_{r}=\mathbf{F}-\mathbf{A}_{n} \mathbf{S}_{e},
$$

ir takumo (stiprumo) sąlygas, kurios bendru atveju išreiškiamos vektorine funkcija:

$$
\mathbf{f}\left(\mathbf{S}_{e}, \mathbf{S}_{r}, \mathbf{S}_{0}\right) \leq 1 .
$$

Taigi aukščiau suformuluotą ekstremini energini principą atitinka šis netiesinio matematinio programavimo uždavinys:

Rasti

$$
\begin{gathered}
\min U_{r}=\frac{1}{2} \mathbf{S}_{r}^{T} \mathbf{D}_{n} \mathbf{S}_{r}, \\
\mathbf{A}_{n} \mathbf{S}_{r}=\mathbf{F}-\mathbf{A}_{n} \mathbf{S}_{e}, \\
\mathbf{f}\left(\mathbf{S}_{e}, \mathbf{S}_{r}, \mathbf{S}_{0}\right) \leq \mathbf{1} .
\end{gathered}
$$

Toliau matematinį modeli (2.77) vadinsime liekamųjų įrąžų analizès uždavinio statine formuluote. Uždavinys (2.77) priskiriamas iškilojo matematinio programavimo uždavinių klasei, jei visi vektorinès takumo funkcijos f komponentai yra iškilosios funkcijos. 


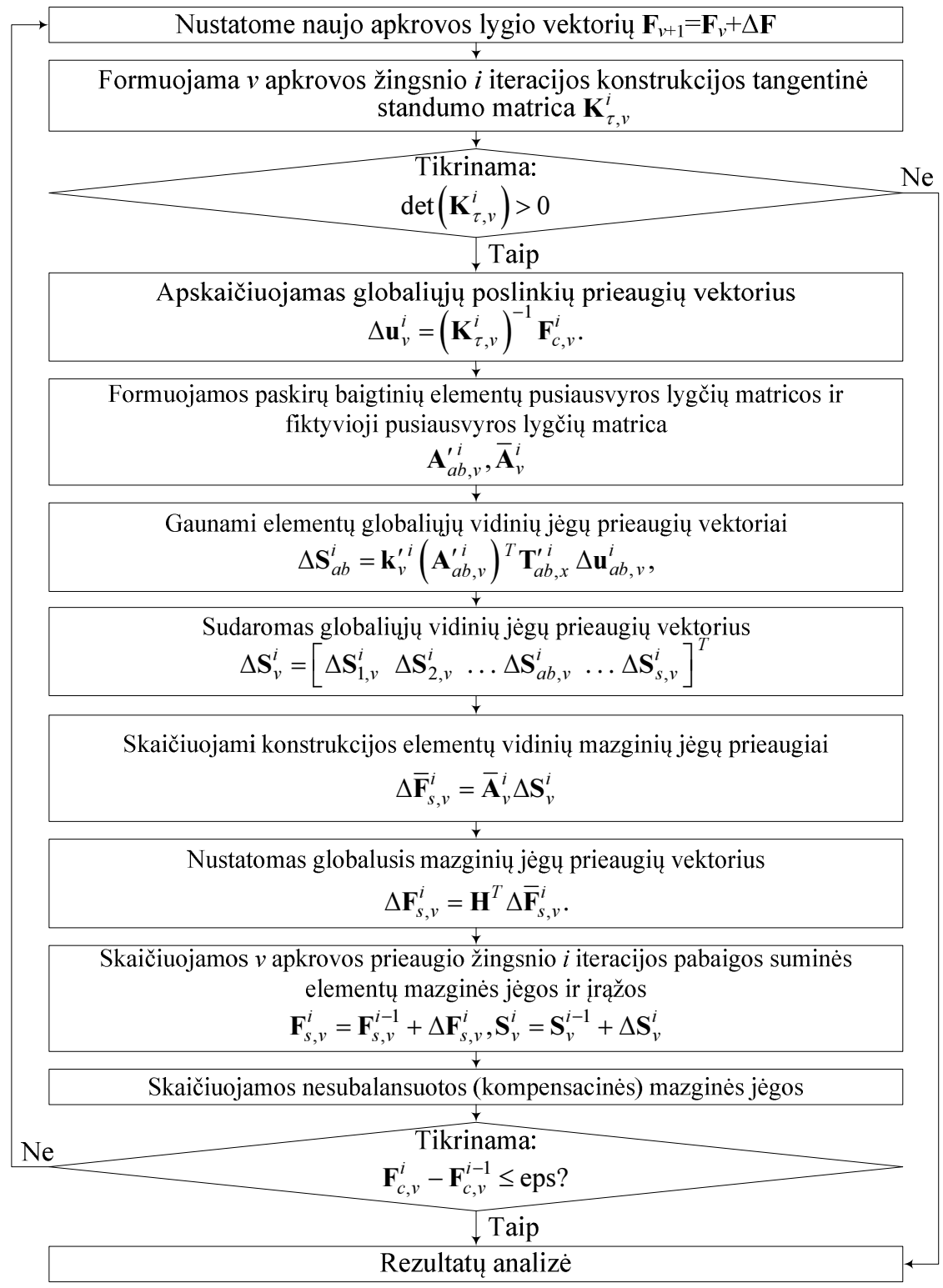

2.7 pav. Newton-Raphson metodo algoritmas

Fig. 2.7. The Newton-Raphson method algorithm 


\subsection{Liekamụjų poslinkių analizès uždavinys}

Tampriosios plastinès sistemos liekamasis deformuotas būvis nustatomas pagal analizès uždavinio kinematinę formuluotę, gaunamą pasitelkus matematinio programavimo dualumo teoriją. (2.77) uždaviniui užrašysime Lagranžo funkciją. Jai sudaryti parenkami daugikliai: takumo sąlygoms - neneigiami daugikliai $\boldsymbol{\lambda} \geq \mathbf{0}$ , o statikos lygtims - neriboto ženklo daugikliai $\mathbf{u}_{r}$ (liekamieji poslinkiai). Taigi, ekstreminiam uždaviniui (2.77) Lagranžo funkcija yra tokia:

$$
\begin{aligned}
\mathscr{L}\left(\mathbf{S}_{r}, \boldsymbol{\lambda}, \mathbf{u}_{r}\right)=\frac{1}{2} \mathbf{S}_{r}^{T} \mathbf{D}_{n} \mathbf{S}_{r}+\boldsymbol{\lambda}^{T}\left(-1+\mathbf{f}\left(\mathbf{S}_{e}, \mathbf{S}_{r}, \mathbf{S}_{0}\right)\right)- \\
\quad \mathbf{u}_{r}^{T}\left(\mathbf{F}-\mathbf{A}_{n} \mathbf{S}_{e}-\mathbf{A}_{n} \mathbf{S}_{r}\right) .
\end{aligned}
$$

Dualaus uždavinio apribojimus sudaro funkcijos (2.78) stacionarumo sąlygos pagal pradinio uždavinio (2.77) nežinomuosius $\mathbf{S}_{r}$ (prilygintos nuliui Lagranžo funkcijos pirmosios išvestinès). Pasirinktu atveju Lagranžo funkcijos stacionarumo sąlygų išraiška tokia:

$$
\frac{\partial \mathscr{L}\left(\mathbf{S}_{r}, \boldsymbol{\lambda}, \mathbf{u}_{r}\right)}{\partial \mathbf{S}_{r}}=\mathbf{D}_{n} \mathbf{S}_{r}+\left[\frac{\partial \mathbf{f}\left(\mathbf{S}_{e}, \mathbf{S}_{r}, \mathbf{S}_{0}\right)}{\partial \mathbf{S}_{r}}\right]^{T} \boldsymbol{\lambda}-\mathbf{A}_{n}{ }^{T} \mathbf{u}_{r}=\mathbf{0} .
$$

Transponavus abi šios lygties puses galima parašyti, kad:

$$
\mathbf{u}_{r}^{T} \mathbf{A}_{n}=\mathbf{S}_{r}^{T} \mathbf{D}_{n}+\lambda^{T}\left[\frac{\partial \mathbf{f}\left(\mathbf{S}_{e}, \mathbf{S}_{r}, \mathbf{S}_{0}\right)}{\partial \mathbf{S}_{r}}\right]=\mathbf{S}_{r}^{T} \mathbf{D}_{n}+\lambda^{T}\left[\nabla \mathbf{f}\left(\mathbf{S}_{e}, \mathbf{S}_{r}, \mathbf{S}_{0}\right)\right] .
$$

Pastarąą $\mathbf{u}_{r}^{T} \mathbf{A}_{n}$ priklausomybę ịrašius į (2.78) formulę, gaunamas naujas Lagranžo funkcijos pavidalas:

$$
\begin{aligned}
\mathscr{L}\left(\mathbf{S}_{r}, \boldsymbol{\lambda}\right) \equiv \frac{1}{2} \mathbf{S}_{r}^{T} \mathbf{D}_{n} \mathbf{S}_{r}-\boldsymbol{\lambda}^{T}\left(\mathbf{1}-\mathbf{f}\left(\mathbf{S}_{e}, \mathbf{S}_{r}, \mathbf{S}_{0}\right)\right)+\mathbf{u}_{r}^{T} \mathbf{F}-\mathbf{S}_{r}^{T} \mathbf{D}_{n} \mathbf{S}_{e}- \\
\boldsymbol{\lambda}^{T}\left[\nabla \mathbf{f}\left(\mathbf{S}_{e}, \mathbf{S}_{r}, \mathbf{S}_{0}\right)\right] \mathbf{S}_{e}-\mathbf{S}_{r}^{T} \mathbf{D}_{n} \mathbf{S}_{r}-\boldsymbol{\lambda}^{T}\left[\nabla \mathbf{f}\left(\mathbf{S}_{e}, \mathbf{S}_{r}, \mathbf{S}_{0}\right)\right] \mathbf{S}_{r}= \\
-\frac{1}{2} \mathbf{S}_{r}^{T} \mathbf{D}_{n} \mathbf{S}_{r}-\boldsymbol{\lambda}^{T}\left(\mathbf{1}-\mathbf{f}\left(\mathbf{S}_{e}, \mathbf{S}_{r}, \mathbf{S}_{0}\right)\right)+\mathbf{u}_{r}^{T} \mathbf{F}-\mathbf{S}_{r}^{T} \mathbf{D}_{n} \mathbf{S}_{e}- \\
\boldsymbol{\lambda}^{T}\left[\nabla \mathbf{f}\left(\mathbf{S}_{e}, \mathbf{S}_{r}, \mathbf{S}_{0}\right)\right]\left(\mathbf{S}_{e}+\mathbf{S}_{r}\right) .
\end{aligned}
$$

Taigi, (2.77) uždaviniui dualus yra šis iškilojo matematinio programavimo uždavinys, kuriam reikia: 
Rasti $\quad \max -\frac{1}{2} \mathbf{S}_{r}^{T} \mathbf{D}_{n} \mathbf{S}_{r}-\boldsymbol{\lambda}^{T}\left(\mathbf{1}-\mathbf{f}\left(\mathbf{S}_{e}, \mathbf{S}_{r}, \mathbf{S}_{0}\right)\right)+\mathbf{u}_{r}^{T} \mathbf{F}-\mathbf{S}_{r}^{T} \mathbf{D}_{n} \mathbf{S}_{e}-$

$$
\lambda^{T}\left[\nabla \mathbf{f}\left(\mathbf{S}_{e}, \mathbf{S}_{r}, \mathbf{S}_{0}\right)\right]\left(\mathbf{S}_{e}+\mathbf{S}_{r}\right),
$$

kai

$$
\mathbf{D S}_{r}+\left[\nabla^{T} \mathbf{f}\left(\mathbf{S}_{e}, \mathbf{S}_{r}, \mathbf{S}_{0}\right)\right] \boldsymbol{\lambda}-\mathbf{A}_{n}{ }^{T} \mathbf{u}_{r}=\mathbf{0}, \boldsymbol{\lambda} \geq \mathbf{0} .
$$

Energinis principas, atitinkantis ekstremumo uždavinio matematini modelị (2.82), yra formuluojamas taip (Čyras 1983; Atkočiūnas et al. 2010): iš visų kinematiškai leistinų liekamųų poslinkių vektorių tikrasis yra tas, kuris atitinka papildomo darbo maksimumą.

Toliau ši matematini modeli vadinsis liekamujų įrąžų analizès uždavinio kinematine formuluote. Išsprendus (2.82) uždavini randami liekamieji poslinkiai $\mathbf{u}_{r}$ ir liekamosios įrąžos $\mathbf{S}_{r}$.

\subsection{Liekamụjų poslinkiụ analizès uždavinys taikant normatyvinius reikalavimus}

Takumo (stiprumo) sąlygos statybinių konstrukcijų projektavimą reglamentuojančiuose dokumentuose (Eurocode 3 2006; STR 2.05.08:2005; ANSI/AISC 360-10) dažnai išreiškiamos tiesinèmis funkcijomis. Bendruoju atveju šias sąlygas galima užrašyti tokia matematine išraiška:

$$
\boldsymbol{\Phi}\left(\mathbf{S}_{e}+\mathbf{S}_{r}\right) \leq \mathbf{S}_{0},
$$

čia $\boldsymbol{\Phi}-(t \times n)$ matmenų konstrukcijos stiprumo (takumo) sąlygų koeficientų matrica; $t$ - takumo (stiprumo) sąlygų skaičius.

Šiuo atveju liekamųjų ịrąžų analizès uždavinys užrašomas taip:

Rasti

$$
\min U_{r}=\frac{1}{2} \mathbf{S}_{r}^{T} \mathbf{D}_{n} \mathbf{S}_{r},
$$

kai

$$
\begin{aligned}
& \mathbf{A}_{n} \mathbf{S}_{r}=\mathbf{F}-\mathbf{A}_{n} \mathbf{S}_{e}, \\
& \boldsymbol{\Phi} \mathbf{S}_{r} \leq \mathbf{S}_{0}-\boldsymbol{\Phi} \mathbf{S}_{e} .
\end{aligned}
$$

Tokio uždavinio kinematinè formuluote yra:

Rasti

$$
\max -\frac{1}{2} \mathbf{S}_{r}^{T} \mathbf{D}_{n} \mathbf{S}_{r}-\boldsymbol{\lambda}^{T} \mathbf{S}_{0}+\mathbf{u}_{r}^{T} \mathbf{F}-\mathbf{S}_{r}^{T} \mathbf{D}_{n} \mathbf{S}_{e}
$$

kai

$$
\begin{gathered}
\mathbf{D}_{n} \mathbf{S}_{r}+\boldsymbol{\Phi}^{T} \boldsymbol{\lambda}-\mathbf{A}_{n}{ }^{T} \mathbf{u}_{r}=\mathbf{0}, \\
\boldsymbol{\lambda} \geq \mathbf{0} .
\end{gathered}
$$


Tai yra iškilojo kvadratinio matematinio programavimo uždaviniai. Panaudojus (2.85) bei (2.88) lygtis, galima gauti liekamujų įažų $\mathbf{S}_{r}$ ir liekamųjų poslinkių vektorių $\mathbf{u}_{r}$ išraiškas:

$$
\begin{aligned}
\mathbf{S}_{r}=\left(\mathbf{D}_{n}^{-1} \mathbf{A}_{n}^{T}\left(\mathbf{A}_{n} \mathbf{D}_{n} \mathbf{A}_{n}^{T}\right)^{-1} \mathbf{A}_{n} \mathbf{D}_{n}^{-1}-\mathbf{D}_{n}^{-1}\right) \mathbf{\Phi}^{T} \boldsymbol{\lambda}+ \\
\quad \mathbf{D}_{n}^{-1} \mathbf{A}_{n}^{T}\left(\mathbf{A}_{n} \mathbf{D}_{n} \mathbf{A}_{n}^{T}\right)^{-1}\left(\mathbf{F}-\mathbf{A}_{n} \mathbf{S}_{e}\right)=\overline{\mathbf{G}} \mathbf{\Phi}^{T} \boldsymbol{\lambda}+\overline{\mathbf{H}}\left(\mathbf{F}-\mathbf{A}_{n} \mathbf{S}_{e}\right), \\
\mathbf{u}_{r}=\left(\mathbf{A}_{n} \mathbf{D}_{n} \mathbf{A}_{n}^{T}\right)^{-1} \mathbf{A}_{n} \mathbf{D}_{n}^{-1} \mathbf{\Phi}^{T} \boldsymbol{\lambda}+\left(\mathbf{A}_{n} \mathbf{D}_{n} \mathbf{A}_{n}^{T}\right)^{-1} \mathbf{F}- \\
\quad\left(\mathbf{A}_{n} \mathbf{D}_{n} \mathbf{A}_{n}^{T}\right)^{-1} \mathbf{S}_{e}=\overline{\mathbf{H}}^{T} \boldsymbol{\Phi}^{T} \boldsymbol{\lambda}+\left(\mathbf{A}_{n} \mathbf{D}_{n} \mathbf{A}_{n}^{T}\right)^{-1}\left(\mathbf{F}-\mathbf{S}_{e}\right),
\end{aligned}
$$

čia $\overline{\mathbf{G}}=\mathbf{D}_{n}^{-1} \mathbf{A}_{n}^{T}\left(\mathbf{A}_{n} \mathbf{D}_{n} \mathbf{A}_{n}^{T}\right)^{-1} \mathbf{A}_{n} \mathbf{D}_{n}^{-1}-\mathbf{D}_{n}^{-1}-$ liekamuju ịą̧žų infliuentinè matrica; $\overline{\mathbf{H}}=\mathbf{D}_{n}^{-1} \mathbf{A}_{n}^{T}\left(\mathbf{A}_{n} \mathbf{D}_{n} \mathbf{A}_{n}^{T}\right)^{-1}$ - liekamujų poslinkių infliuentinè matrica;

Gautas (2.90) ir (2.91) išraiškas irašius i (2.84) ir atlikus atitinkamus matematinius veiksmus, gaunama (2.87)-(2.89) uždavinio modifikacija iškilosios kvadratinès funkcijos ekstremumo uždavinys neneigiamų vektorių $\lambda$ ortante:

Rasti $\max \frac{1}{2} \boldsymbol{\lambda}^{T} \boldsymbol{\Phi} \overline{\mathbf{G}} \boldsymbol{\Phi}^{T} \boldsymbol{\lambda}-\boldsymbol{\lambda}^{T}\left(\mathbf{S}_{0}-\boldsymbol{\Phi} \mathbf{S}_{e}\right)+\boldsymbol{\lambda}^{T} \mathbf{\Phi} \overline{\mathbf{H}}\left(\mathbf{F}-\mathbf{A}_{n} \mathbf{S}_{e}\right)+$ const

kai

$\lambda \geq \mathbf{0}$.

čia

const $=\frac{1}{2} \mathbf{F}^{T}\left(\mathbf{A}_{n} \mathbf{D}_{n} \mathbf{A}_{n}^{T}\right)^{-1} \mathbf{F}+\frac{1}{2} \mathbf{S}_{e}^{T} \mathbf{A}_{n}^{T}\left(\mathbf{A}_{n} \mathbf{D}_{n} \mathbf{A}_{n}^{T}\right)^{-1} \mathbf{A}_{n} \mathbf{S}_{e}-\mathbf{F}^{T}\left(\mathbf{A}_{n} \mathbf{D}_{n} \mathbf{A}_{n}^{T}\right)^{-1} \mathbf{A}_{n} \mathbf{S}_{e}$

- narys, kuris neturi itakos uždavinio (2.92) sprendimui ir esant optimaliam sprendiniui tampa lygus nuliui.

Uždaviniai (2.78), (2.82), (2.84)-(2.86), (2.87)-(2.89) arba (2.92) yra netiesinio iškilojo matematinio programavimo uždaviniai, kurių nežinomieji yra vektoriai $\mathbf{S}_{r}, \mathbf{u}_{r}$, ir $\boldsymbol{\lambda}$.

\subsection{Stiprumo sąlygos sudétingo deformavimosi būviui}

Formuluojant tamprių plastinių konstrukcijų analizès uždavinius bei jų matematinius modelius, vienas iš svarbiausių aspektų - stiprumo sąlygų parinkimas. Nagrinejjant erdvines konstrukcijas kalbama apie sudètingą deformacijų būvị. Tikslinga būtų naudoti stiprumo sąlygas, kurios apimtų ne tik tempimo-gniuždymo, bet lenkimus apie vieną ir kitą konstrukcijos elemento aši. Stiprumo sąlygos, esant sudètingam deformacijų būviui dažnai aprašomos 
normatyviniuose dokumentuose, reglamentuojančiuose statybinių konstrukcijų projektavimą (ANSI/AISC 360-10).
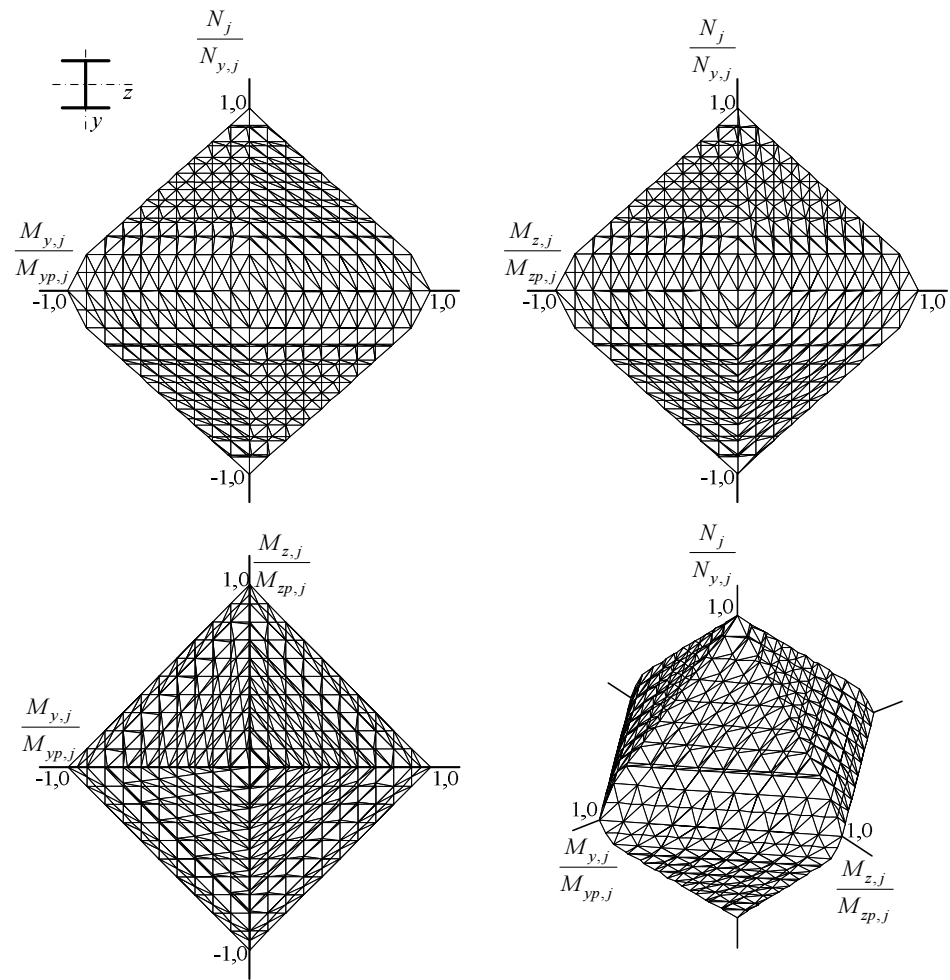

2.8 pav. Plastiškumo paviršius pagal AISC-LRFD

Fig. 2.8. The yield surface by AISC-LRFD strength conditions

Sijinių-koloninių elementų plastinio stiprumo paviršius pagal AISC-LRFD (2.8 pav.) (Kim S.-E. et al. 2001; Aminmansour 2000; ANSI/AISC 360-10) projektavimo norminius dokumentus užrašomas taip:

$$
\begin{aligned}
& 1 \geq \frac{N_{j}}{N_{y, j}}+\frac{8}{9} \frac{M_{y, j}}{M_{y p, j}}+\frac{8}{9} \frac{M_{z, j}}{M_{z p, j}}, k a i \frac{N_{j}}{N_{y, j}} \geq \frac{2}{9} \frac{M_{y, j}}{M_{y p, j}}+\frac{2}{9} \frac{M_{z, j}}{M_{z p, j}}, \\
& 1 \geq \frac{N_{j}}{2 N_{y, j}}+\frac{M_{y, j}}{M_{y p, j}}+\frac{M_{z, j}}{M_{z p, j}}, k a i \frac{N_{j}}{N_{y, j}}<\frac{2}{9} \frac{M_{y, j}}{M_{y p, j}}+\frac{2}{9} \frac{M_{z, j}}{M_{z p, j}},
\end{aligned}
$$

čia $N_{j}$ - konstrukcijos elementą veikianti ašinè jèga j-ajame pjūvyje; $N_{y, j}-$ tempiamo ar gniuždomo konstrukcijos elemento skerspjūvio skaičiuotinè ribiné ašinè jèga $j$-ajame pjūvyje; $M_{y, j}$ - konstrukcijos elementą veikiantis lenkimo momentas apie profilio „silpnają“ aši $j$-ajame pjūvyje; $M_{y p_{j} .}=f_{u} \cdot W_{y p l} \quad$ konstrukcijos elemento skerspjūvio skaičiuotinis ribinis lenkimo momentas apie 
„silpnąąa“ aši $j$-ajame pjūvyje; $M_{z, j}$ - konstrukcijos elementą veikiantis lenkimo momentas apie profilio „stipriają“ aši $j$-ajame pjūvyje; $M_{z p, j}=f_{u} \cdot W_{z p l} \quad$ konstrukcijos elemento skerspjūvio skaičiuotinis ribinis lenkimo momentas apie „stipriająa" aši j-ajame pjūvyje.

Visos aukščiau paminètos ribinès irą̧žos nustatomos pagal konstrukcijų projektavimą reglamentuojančius normatyvinius dokumentus (ANSI/AISC 36010). Vietinis konstrukcijos stabilumas tikrinamas, kai gniuždomieji elementai apkrauti iki jų kritinių jègų reikšmių. Gniuždomų elementų kritinès įrąžų reikšmès šiame darbe apskaičiuojamos pagal projektavimo normų reikalavimus. Eurocode 32006 normatyviniuose dokumentuose yra pateikiama tokia išraiška:

$$
N_{b, R d}=\frac{\chi A f_{u}}{\gamma_{\mathrm{M} 1}},
$$

čia $N_{b, R d}$ - skaičiuotinè gniuždomo elemento klupamoji galia; $\chi$ - klupumo koeficientas; $A$ - konstrukcijos elemento skerspjūvio plotas; $f_{u}$ - konstrukcijos medžiagos stiprumo (takumo) riba; $\gamma_{\mathrm{M} 1}$ - dalinis koeficientas (laikomas lygus 1,0).

Klupumo koeficientas $\chi$ pagal atitinkamą sąlygini liauni $\bar{\lambda}$ apskaičiuojamas pagal formulę:

$$
\chi=\frac{1}{\Phi+\sqrt{\Phi^{2}-\bar{\lambda}^{2}}}, \quad \text { bet } \chi \leq 1,0
$$

čia $\Phi=0,5\left[1+\alpha(\bar{\lambda}-0,2)+\bar{\lambda}^{2}\right] ; \quad \bar{\lambda}=\sqrt{A f_{u} / N_{c r}} ; N_{c r}-$ tamprioji kritinè jèga, apskaičiuojama pagal formulę:

$$
N_{c r}=\pi^{2} E I / l_{b}^{2},
$$

čia $E$ - konstrukcijos medžiagos tamprumo modulis; $I$ - konstrukcijos elemento skerspjūvio inercijos momentas; $l_{b}$ - klumpamasis ilgis nagrinejjamoje klupumo plokštumoje, apskaičiuojamas pagal formulę:

$$
l_{b}=\mu l,
$$

čia $\mu$ - skaičiuojamojo ilgio koeficientas, apskaičiuojamas pagal formules pateiktas 2.2 lentelèje; $l$ - konstrukcijos elemento ilgis.

Klupdymo koeficientai pagal (2.91) formulę apskaičiuojami skaidant erdvinị rèmą i plokščius remus ir atskirai nustatant koeficientus dviejose klupdymo plokštumose.

Globalus, visos konstrukcijos, stabilumas tikrinamas skaičiuojant visos konstrukcijos tangentinès standumo matricos determinantą pagal (2.1) lygti, paskutiniame skaitinès realizacijos skaičiavimo etape. Jei determinanto reikšmé 
tampa lygi nuliui - konstrukcija prarado bendrą stabilumą. Tolimesni skaičiavimai nèra vykdomi.

Sprendžiant analizės uždavinị yra naudojamos stiprumo sąlygos (2.93). Galimi du šių sąlygu panaudojimo variantai. Pirmasis variantas - naudoti (2.93) sąlygas, jų nekeičiant, analizès uždavinio sprendimui pagal (2.77) arba (2.82) formuluotes. Antrasis variantas - pakeisti stiprumo sąlygas, užrašant jas tiesinèmis funkcijomis:

$$
\begin{aligned}
& M_{z p, j} \geq c_{y, j} P_{j}+\frac{8}{9} m_{y, j} M_{y, j}+\frac{8}{9} M_{z, j}, \text { kai } c_{y, j} P_{j} \geq \frac{2}{9} m_{y, j} M_{y}+\frac{2}{9} M_{z, j}, \\
& M_{z p, j} \geq \frac{1}{2} c_{y, j} P_{j}+m_{y, j} M_{y, j}+M_{z, j}, \text { kai } c_{y, j} P_{j}<\frac{2}{9} m_{y, j} M_{y}+\frac{2}{9} M_{z, j},
\end{aligned}
$$

čia $c_{y, j}=M_{z p_{j} /} / P_{y_{j}, j} ; m_{y_{j}}=M_{z p, j} / M_{y p_{j}, j}$.

Panaudojus šias išraiškas analizès uždavinys gali būti sprendžiamas naudojantis (2.84)-(2.86), (2.87)-(2.89) ar (2.92) matematiniais modeliais.

Projektavimo normatyviniai dokumentai kaip matyti 2.8 paveiksle, pateikia ištiesintas stiprumo sąlygas, kurios sąlygoja didesni konstrukcijų patikimumą, bet mažina tikslumą aprašant konstrukcijos darbą bei tikraji IDB. (Kim et al. 2001; Chiorean et al. 2005) darbuose nagrinejjami konstrukcijų analizès uždaviniai, kuriuose naudojamos Orbison stiprumo sąlygos. Minètų autorių atlikti tyrimai rodo, kad šios sąlygos tiksliau aprašo konstrukcijų darbą. Jų išraiška užrašoma:

$$
1 \geq 1,15 n_{j}^{2}+m_{z, j}^{2}+m_{y, j}^{4}+3,67 n_{j}^{2} m_{z, j}^{2}+3,0 n_{j}^{6} m_{y, j}^{2}+4,65 m_{z, j}^{4} m_{y, j}^{2},
$$

čia $n_{j}=N_{j} / N_{y, j} ; \quad m_{y, j}=M_{y, j} / M_{y p, j}$ - elemento skerspjūvio ploto "silpnoji" ašis; $m_{z, j}=M_{z, j} / M_{z p_{j}, j}$ elemento skerspjūvio ploto "stiprioji”" ašis.

Orbison stiprumo sąlygų takumo paviršius yra pateiktas 2.9 paveiksle.

Aukščiau minètos stiprumo sąlygos, apibrèžiančios sudètingą İD, nevertina sukimo įrąžos. Tad sukimo stiprumo sąlyga turi buti vertinama atskirai. Normatyviniai dokumentai (Eurocode 3 2006) siūlo sukimo stiprumo sąlygą išreikšti taip:

$$
\frac{T_{E d}}{T_{R d}} \leq 1,0,
$$

čia $T_{E d}$ yra skaičiuotinè sukamojo momento reikšmė; $T_{R d}$ yra skaičiuotinè skerspjūvio sukamoji galia. 
2.2 lentelè. Laisvujų rèmų skaičiuojamojo ilgio koeficientai (pagal STR 2.05.08:2005)

Table 2.2. Free frames effective length coefficients (by STR 2.05.08:2005)

\begin{tabular}{|c|c|c|c|}
\hline \multirow[t]{2}{*}{ Laisvujų rèmų skaičiuojamosios schemos } & \multirow{2}{*}{$\begin{array}{c}\text { Formulès koeficientui } \mu \\
\text { apskaičiuoti }\end{array}$} & \multicolumn{2}{|c|}{$\begin{array}{c}\text { Koeficientai } n \text { ir } p \text { naudojami } 2 \\
\text { stulpelyje }\end{array}$} \\
\hline & & Vienaangių rėmų & Daugiaangių rèmų \\
\hline 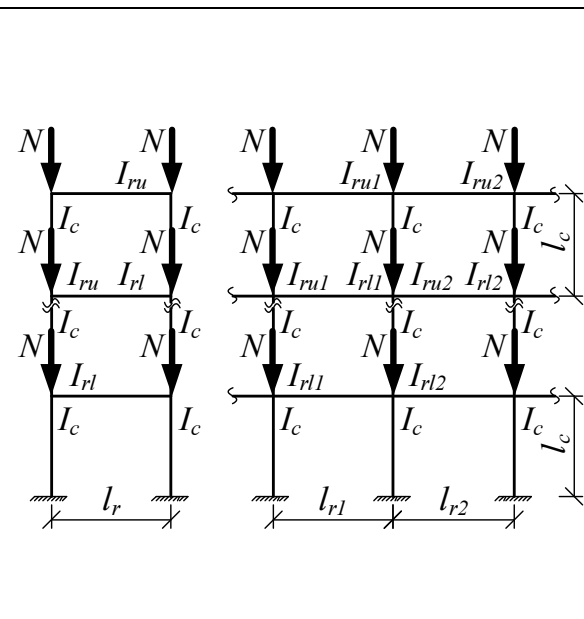 & $\begin{array}{c}\text { Apatinis aukštas: } \\
\sqrt{\frac{n+0,56}{n+0,14}} \\
\text { Kiti aukštai: } \\
\text { kai } n \leq 0,2 \\
(p+0,68) \sqrt{n+0,22} \\
\frac{(\text { Kai } n \geq 0,2}{\sqrt{0,68 p(p+0,9)(n+0,08)+0,1 n}} \\
\frac{(p+0,63) \sqrt{n+0,28}}{\sqrt{p n(p+0,9)+0,1 n}}\end{array}$ & 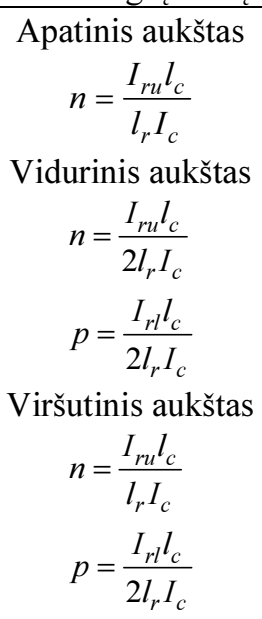 & $\begin{array}{l}\text { Apatinis aukštas } \\
n=\frac{k\left(n_{1}+n_{2}\right)}{k+1} \\
\text { Vidurinis aukštas } \\
n=\frac{k\left(n_{1}+n_{2}\right)}{k+1} \\
p=\frac{k\left(p_{1}+p_{2}\right)}{k+1} \\
\text { Viršutinis aukštas } \\
n=\frac{2 k\left(n_{1}+n_{2}\right)}{k+1} \\
p=\frac{k\left(p_{1}+p_{2}\right)}{k+1}\end{array}$ \\
\hline \multicolumn{4}{|c|}{$\begin{array}{l}\text { Žymenys: } \\
n_{1}=\frac{I_{r u, 1} l_{c}}{l_{r, 1} I_{c}} ; n_{2}=\frac{I_{r u, 2} l_{c}}{l_{r, 2} I_{c}} ; p_{1}=\frac{I_{r l, 1} l_{c}}{l_{r, 1} I_{c}} ; p_{2}=\frac{I_{r l, 2} l_{c}}{l_{r, 2} I_{c}} ; I_{c} \text { ir } l_{c} \text {-tikrinamosios kolonos skerspjūvio inercijos momentas ir } \\
\text { ilgis; } l_{r} l_{r 1} \text { ir } l_{r 2}-\text { rèmo tarpatramiai; } I_{r u}, I_{r u 1}, I_{r u 2} \text { ir } I_{r l}, I_{r l 1}, I_{r l 2}-\text { prie tikrinamosios kolonos viršutinių ir apatinių } \\
\text { galų prijungtų rèmo sijų skerspjūvių inercijos momentai. } \\
\text { Pastaba. Kraštinès laisvojo daugiaatramio (daugiaangio) rèmo kolonos koeficientas } \mu \text { apskaičiuojamas kaip vienaangio rèmo } \\
\text { kolonu. }\end{array}$} \\
\hline
\end{tabular}



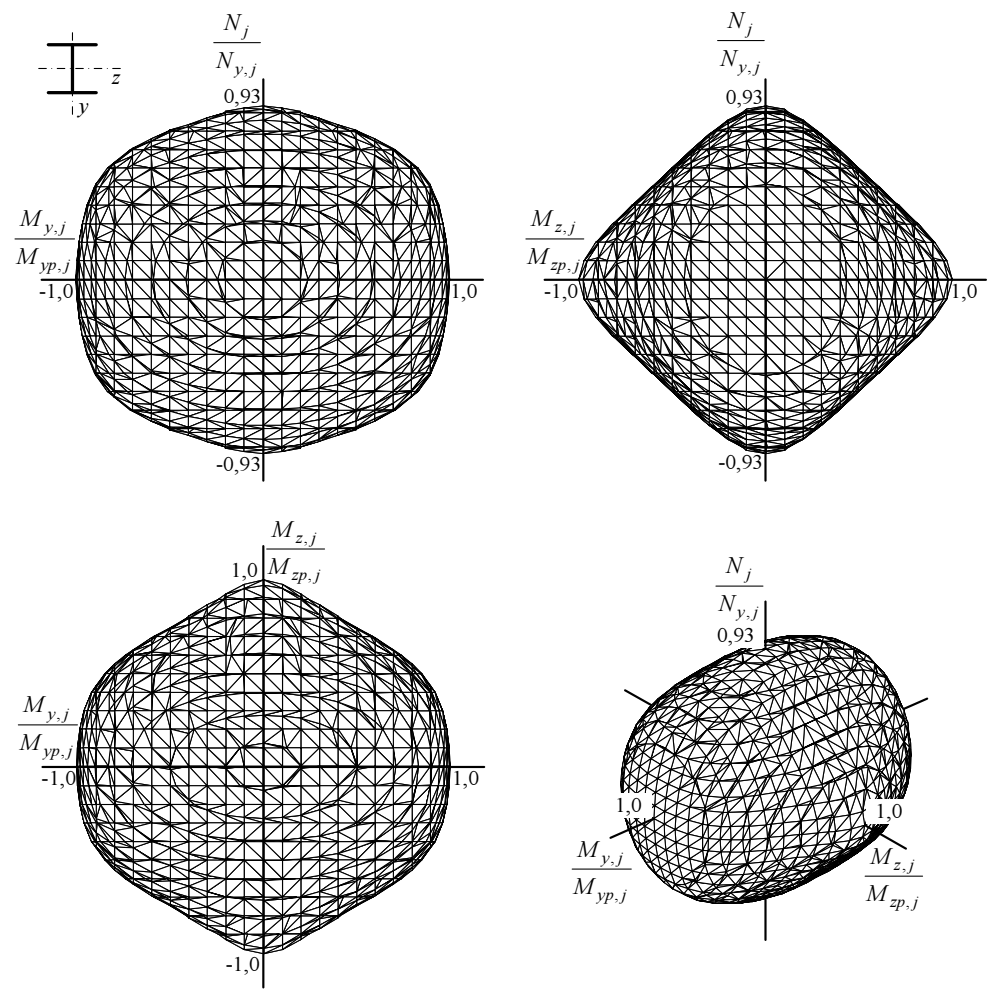

2.9 pav. Plastiškumo paviršius pagal Orbison (Kim S.-E. et al. 2001) stiprumo sąlygas

Fig. 2.9. The yield surface by Orbison (Kim S.-E. et al. 2001) strength conditions

Konstrukcijos elemento sukamoji galia (Икрин 2004; Trahair et al. 2008) darbuose išreiškiama formule:

$$
T_{R d}=\tau_{y} W_{t},
$$

čia $\tau_{y}$ yra takumo itempis grynosios šlyties metu; $W_{t}$ yra atsparumo momentas esant laisvam sukimui, apskaičiuojamas pagal formulę:

$$
W_{t}=\frac{I_{t}}{t_{\max }},
$$

čia $I_{t}$ yra sukimo konstanta; $t_{\max }$ yra didžiausias nagrinëjamo konstrukcijos elemento skerspjūvio storis. 


\subsection{Ekstreminio energinio principo naudojimo pagrindimas}

Geometriškai netiesinių tampriu plastinių konstrukcijų tikrojo IDB nustatymui ekstreminio energinio principo apie minimalią papildomo deformavimo energiją taikymas yra grindžiamas skaitiniu eksperimentu. Jis atliekamas su standžiai itvirtinta galuose sija, apkrauta jèga $F$. Nagrinejamos konstrukcijos diskretinis modelis yra pateiktas 1.6 paveikslo a dalyje. Sijos geometriniai rodikliai: skerspjūvio plotas $A=28,5 \mathrm{~cm}^{2}$; inercijos momentas $I=1943 \mathrm{~cm}^{4}$; plastinis atsparumo momentas $W_{p l}=225 \mathrm{~cm}^{3}$; fiziniai parametrai: tamprumo modulis $E=206 \mathrm{GPa}$; takumo riba $f_{u}=550 \mathrm{MPa}$; ribinis lenkimo momentas $M_{0}=12375 \mathrm{kNcm}$; ribinè ašinè jèga $N_{0}=1567,5 \mathrm{kNcm}$.

Skaičiavimams buvo pasirinktos stiprumo sąlygos skirtos plokščiu konstrukcijų analizei (Atkočiūnas et al. 2010):

$$
\left\{\begin{array}{l}
M_{j} \leq M_{0},-M_{j} \leq M_{0}, \\
c_{j} N_{j}+1 / 1,18 M_{j} \leq M_{0}, c_{j} N_{j}-1 / 1,18 M_{j} \leq M_{0},
\end{array}\right.
$$

čia $N_{j}$ ir $M_{j}$ - skaičiuotinès įrąžų reikšmès $j$-ajame pjūvyje; $c_{j}=N_{0, j} / M_{0, j}-$ ribinių įrąžų reikšmių santykis.

Panagrinèkime sijos taško, kuriame pridèta jèga, vertikalaus poslinkio kitimą jègai $F$ (2.10 pav. a) didejjant nuo nulio iki didžiausios reikšmès, kai visuose sijos skaičiuojamuosiuose pjūviuose atsiras plastinès deformacijos (plastiniai lankstai) ir statiškai neišsprendžiama sija taps statiškai išsprendžiama konstrukcija.

Sprendžiami 3 uždaviniai:

1. Tiesinè analizè panaudojant tamprių sprendinių metodą.

2. Netiesinè analizė panaudojant tamprių sprendinių metodą.

3. Tampri plastiné netiesinè analizé taikant matematini modelị - (2.84)(2.86) arba (2.87)-(2.89).

Visų trijų skaičiavimų rezultatai yra pateikti 2.3 lentelëje.

Pirmieji du skaičiavimai buvo atliekami trimis etapais-pakopomis, kurie yra pateikti 2.10 paveiksle. Tampraus skaičiavimo tiesinès analizès etapai yra pateikti 2.10 paveikslo b, c ir d dalyse, e dalyje pateiktas konstrukcijos diskretinis modelis gaunamas po paskutinio skaičiavimo etapo. Tampraus skaičiavimo netiesinès analizès etapai yra pateikti 2.10 paveikslo $f, g$ ir $h$ dalyse, $i$ dalyje pateiktas konstrukcijos diskretinis modelis gaunamas po paskutinio skaičiavimo etapopakopos. Svarbu pažymėti, kad tampraus skaičiavimo tiesinès analizès metu sprendžiama eilè uždavinių didinant apkrovą bei tikrinant plastinių deformacijų atsiradimą skaičiuojamuosiuose pjūviuose ir po kiekvieno etapo-pakopos keičiamas diskretinis modelis, îvedant lankstą pjūvyje, kuriame pasireiškè plastinès deformacijos. O tampraus skaičiavimo netiesinès analizès metu, ne tik 
ìvedamas lankstas, bet ir keičiama vidurinio mazgo koordinatè. Šių dviejų skaičiavimų sąlyginès lenkimo momentų diagramos po kiekvieno etapo pakopos yra pateiktos $j, k$ ir $l$ dalyse.
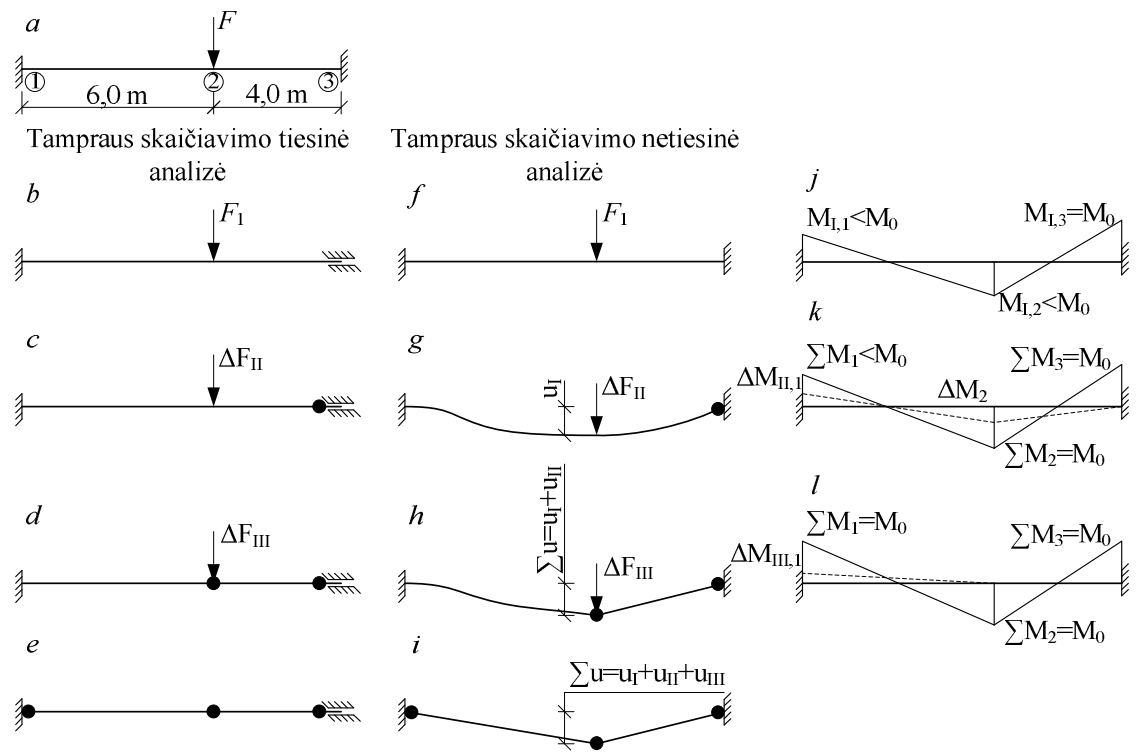

2.10 pav. Plokščia sija ir jos skaičiavimo etapai

Fig. 2.10. The two-dimensional beam and it's calculation stages

Pirmieji du skaičiavimai buvo atliekami trimis etapais-pakopomis, kurie yra pateikti 2.10 paveiksle. Tampraus skaičiavimo tiesinès analizès etapai yra pateikti 2.10 paveikslo b, $\mathrm{c}$ ir d dalyse, e dalyje pateiktas konstrukcijos diskretinis modelis gaunamas po paskutinio skaičiavimo etapo. Tampraus skaičiavimo netiesinès analizès etapai yra pateikti 2.10 paveikslo $f, g$ ir $h$ dalyse, $i$ dalyje pateiktas konstrukcijos diskretinis modelis gaunamas po paskutinio skaičiavimo etapopakopos. Svarbu pažymèti, kad tampraus skaičiavimo tiesinès analizès metu sprendžiama eilè uždavinių didinant apkrovą bei tikrinant plastinių deformacijų atsiradimą skaičiuojamuosiuose pjūviuose ir po kiekvieno etapo-pakopos keičiamas diskretinis modelis, ịvedant lankstą pjūvyje, kuriame pasireiškè plastinès deformacijos. O tampraus skaičiavimo netiesinès analizès metu, ne tik ivedamas lankstas, bet ir keičiama vidurinio mazgo koordinatè. Šių dviejų skaičiavimų sąlyginès lenkimo momentų diagramos po kiekvieno etapo pakopos yra pateiktos $j, k$ ir $l$ dalyse.

Trečiojo skaičiavimo metu pasikeitimai diskretiniame modelyje nèra sekami. Tiesiog pasirenkamas apkrovos lygis ir atliekamos tampraus skaičiavimo netiesinè ir tampri plastinè netiesinė analizès, kurių rezultatų suma ir yra İDB dydžiai. 
2.3 lentelè. Plokščios sijos skaičiavimo rezultatai

Table 2.3. The two-dimensional beam calculations results

\begin{tabular}{|c|c|c|c|c|c|c|c|c|c|}
\hline & \multicolumn{3}{|c|}{ I pakopa (I plastinis lankstas) } & \multicolumn{3}{|c|}{ II pakopa (II plastinis lankstas) } & \multicolumn{3}{|c|}{ III pakopa (III plastinislankstas) } \\
\hline & \multicolumn{2}{|c|}{$\begin{array}{c}\text { Tamprus } \\
\text { skaičiavimas }\end{array}$} & \multirow{2}{*}{$\begin{array}{c}\text { Tampraus } \\
\text { skaičiavimo } \\
\text { netiesinė } \\
\text { analizė } \\
+ \\
\text { tampri } \\
\text { plastinè } \\
\text { netiesinè } \\
\text { analize } \\
\mathrm{F}_{\mathrm{l}}=89,01 \mathrm{kN}\end{array}$} & \multicolumn{2}{|c|}{$\begin{array}{c}\text { Tamprus } \\
\text { skaičiavimas }\end{array}$} & \multirow{2}{*}{$\begin{array}{c}\text { Tampraus } \\
\text { skaičiavimo } \\
\text { netiesine } \\
\text { analizė } \\
+ \\
\text { tampri } \\
\text { plastine } \\
\text { netiesine } \\
\text { analizè } \\
\mathrm{F}_{\mathrm{II}}=107,85 \\
\mathrm{kN}\end{array}$} & \multicolumn{2}{|c|}{$\begin{array}{c}\text { Tamprus } \\
\text { skaičiavimas }\end{array}$} & \multirow{2}{*}{$\begin{array}{c}\text { Tampraus } \\
\text { skaičiavime } \\
\text { netiesinè } \\
\text { analize } \\
+ \\
\text { tampri } \\
\text { plastine } \\
\text { netiesine } \\
\text { analize } \\
\mathrm{F}_{\text {III }}=112,66 \\
\mathrm{kN}\end{array}$} \\
\hline & $\begin{array}{c}\text { Tiesinè } \\
\text { analizè } \\
\mathrm{F}_{\mathrm{I}}=85,94 \\
\mathrm{kN}\end{array}$ & $\begin{array}{c}\begin{array}{c}\text { Netiesinè } \\
\text { analizè }\end{array} \\
\mathrm{F}_{\mathrm{I}}=89,01 \\
\mathrm{kN}\end{array}$ & & $\begin{array}{c}\text { Tiesine } \\
\text { analizè } \\
\Delta \mathrm{F}_{\mathrm{II}}=14,32 \\
\mathrm{kN} \\
(\mathrm{\Sigma F}=100,26 \\
\mathrm{kN})\end{array}$ & $\begin{array}{c}\begin{array}{c}\text { Netiesine } \\
\text { analize }\end{array} \\
\Delta \mathrm{F}_{\mathrm{II}}=18,37 \\
\mathrm{kN} \\
(\Sigma \mathrm{F}=107,38 \\
\mathrm{kN})\end{array}$ & & $\begin{array}{c}\text { Tiesine } \\
\text { analizè } \\
\Delta \mathrm{F}_{\mathrm{III}}=2,86 \\
\mathrm{kN} \\
(\mathrm{\Sigma} \mathrm{F}=103,12 \\
\mathrm{kN})\end{array}$ & $\begin{array}{c}\text { Netiesine } \\
\text { analize } \\
\Delta \mathrm{F}_{\mathrm{III}}=14,20 \\
\mathrm{kN} \\
(\Sigma \mathrm{F}=121,58 \\
\mathrm{kN})\end{array}$ & \\
\hline$N_{1-2}, \mathrm{kN}$ & 0 & 110,2549 & 110,2542 & 0 & $\begin{array}{c}98,5792 \\
(\Sigma=208,8340)\end{array}$ & 203,7681 & $\begin{array}{c}0 \\
(\Sigma=0)\end{array}$ & $\begin{array}{c}199,3199 \\
(\Sigma=408,1539)\end{array}$ & 239,311 \\
\hline$M_{1}, \mathrm{kNcm}$ & -8250 & $-8249,59$ & $-8249,56$ & $\begin{array}{c}-2406,25 \\
(\Sigma=- \\
10656,25) \\
\end{array}$ & $\begin{array}{c}-2406,24 \\
(\Sigma=- \\
10655,83) \\
\end{array}$ & $-10654,1$ & $\begin{array}{l}-1718,75 \\
(\Sigma=-12375)\end{array}$ & $\begin{array}{c}-1719,46 \\
(\Sigma=-12375,3)\end{array}$ & $-12373,1$ \\
\hline$M_{2, \mathrm{R}}, \mathrm{kNcm}$ & -9900 & $-9899,45$ & $-9899,42$ & $\begin{array}{c}-2475 \\
(\Sigma=-12375)\end{array}$ & $\begin{array}{c}-2475,12 \\
(\Sigma= \\
12374,57) \\
\end{array}$ & $-12372,3$ & $(\Sigma=-12375)$ & $\begin{array}{c}-0,29942 \\
(\Sigma=-12374,9)\end{array}$ & $-12371,5$ \\
\hline$N_{2-3}, \mathrm{kN}$ & 0 & 110,4811 & 110,4803 & $\begin{array}{c}0 \\
(\Sigma=0)\end{array}$ & $\begin{array}{c}98,6206 \\
(\Sigma=209,1017) \\
\end{array}$ & 203,7248 & $\begin{array}{c}0 \\
(\Sigma=0)\end{array}$ & $\begin{array}{c}199,2877 \\
(\Sigma=408,3893) \\
\end{array}$ & 239,1102 \\
\hline$M_{2, \mathrm{~L}}, \mathrm{kNcm}$ & 9900 & 9900,267 & 9900,232 & $\begin{array}{c}2475 \\
(\Sigma=12375)\end{array}$ & $\begin{array}{c}2475,109 \\
(\Sigma=12375,38)\end{array}$ & 12375 & $\begin{array}{c}0 \\
(\Sigma=12375)\end{array}$ & $\begin{array}{c}0 \\
(\Sigma=12375,38)\end{array}$ & 12375 \\
\hline$M_{3}, \mathrm{kNcm}$ & 12375 & 12375,05 & 12375 & $\begin{array}{c}0 \\
(\Sigma=12375)\end{array}$ & $\begin{array}{c}0,0165 \\
(\Sigma=12375,07)\end{array}$ & 12375 & $\begin{array}{c}0 \\
(\Sigma=12375)\end{array}$ & $\begin{array}{c}0 \\
(\Sigma=12375,07)\end{array}$ & 12375 \\
\hline $\begin{array}{c}u, \mathrm{~cm} \\
\text { (Vertikalus, } \\
\text { apkrovos } \\
\text { pridèjimo } \\
\text { vietoje) }\end{array}$ & 9,8936 & 9,8952 & 9,8951 & $\begin{array}{c}3,5040 \\
(\Sigma=13,3976)\end{array}$ & $\begin{array}{c}3,5070 \\
(\Sigma=13,4022)\end{array}$ & 13,4001 & $\begin{array}{c}5,1529 \\
(\Sigma=18,5505)\end{array}$ & $\begin{array}{c}5,1636 \\
(\Sigma=18,5658)\end{array}$ & 18,56 \\
\hline
\end{tabular}


Gautų rezultatų analizè leidžia teigti, kad trečiasis, šiame darbe pasiūlytas tikrojo IDDB nustatymo skaičiavimas, galiausiai duoda praktiškai identiškas poslinkių reikšmes toms, kurios gaunamos tampraus skaičiavimo tiesinès ir netiesinès analizių metu. Gaunama kritinè apkrovos reikšmė (kuriai esant pasireiškia plastinès deformacijos trijuose skaičiuojamuosiuose pjūviuose) yra mažesnė ir tai galima vertinti, kaip tam tikrą atsargą vertinant konstrukcijos stiprumą. Tokiu būdu, metodika pasirinkta realiam konstrukcijos İDB nustatyti, turi tam tikrus privalumus:

1. Vykdant konstrukcijos analizę ir norint nustatyti tikraji deformuotaji būvị, nereikia sekti plastinių lankstų susidarymo bei keisti pradinio diskretinio modelio. Skaičiavimas atliekamas per vieną žingsnị;

2. Apskaičiuoti konstrukcijos poslinkiai yra tokie patys, ribiné apkrovos reikšmė gaunama su tam tikra atsarga.

Reziumuojant galima teigti, kad vykdant optimizavimo uždavinio iteracinio skaičiavimo procesą, tikram İDB nustatyti tikslinga naudoti aprašytą tamprių plastinių konstrukcijų analizę.

\subsection{Analizès uždavinio skaitinè realizacija}

Aukščiau esančiame skyriuje atliktas skaitinis eksperimentas yra daugiau analitinio pobūdžio, labiau ịrodantis pasirinkto ekstreminio energinio principo efektyvumą, lyginant su kitais skaičiavimo principus. Geriausiai principo efektyvumą ir rezultatų patikimumą parodytų realios konstrukcijos analizè bei jos rezultatų palyginimas su natūriniais bandymais. Tam buvo pasirinkta dviejų aukštu erdvinè rèminė konstrukcija, kuri buvo išstudijuota darbuose: Kim and Kang (2002), Kim et al. (2003) (šiuose darbuose yra bandoma reali rèminé konstrukcija) Kim, Lee (2002) (šiame darbe pateikta to paties remo diskretinio modelio, sumodeliuoto ABAQUS programos aplinkoje, analizè).

Konstrukcijos elementai modeliuojami iš $\mathrm{H} 150 \times 150 \times 7 \times 10$ tipo plieno profiliuočių. Rèmo gabaritiniai matmenys yra pateikti 2.11 paveiksle - plotis $x$ ašies kryptimi 2,5 m, ilgis $y$ ašies kryptimi 3,0 m, aukštis nuo kolonos elementu atramų iki antro aukšto grindų 1,76 $\mathrm{m}$ ir aukštis nuo antro aukšto grindų iki stogo 2,2 m. Visi elementų skerspjūvio plotų geometriniai ir fiziniai parametrai yra pastovūs visame konstrukcijos elemento ilgyje. Visų konstrukcijos elementų takumo (stiprumo) riba yra $320 \mathrm{MPa}$, tamprumo modulis $221 \mathrm{GPa}$ ir šlyties modulis $85 \mathrm{GPa}$. Yra nagrinejami trys skirtingi konstrukcijos modelio apkrovimo variantai, kurie yra pateikti 2.4 lenteleje. 
(a)

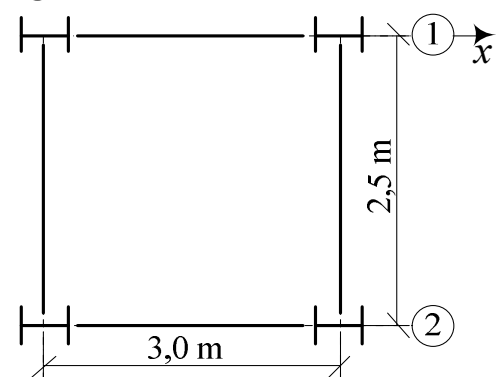

$\underbrace{A}_{z}$
(B) (b)

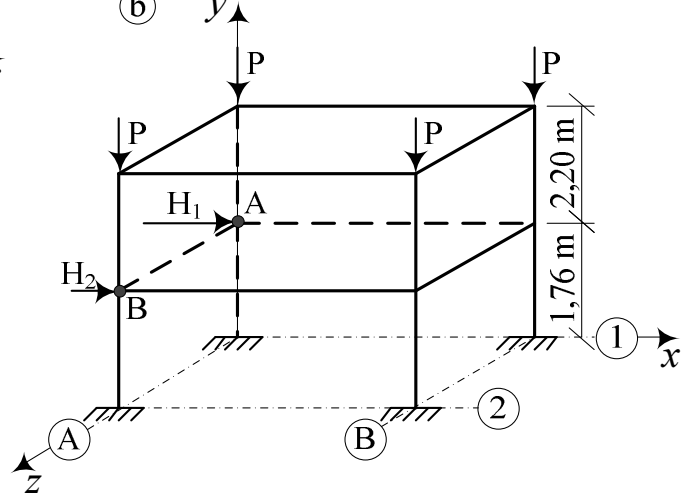

2.11 pav. Erdvinio dviejų aukštų rèmo diskretinis modelis (a - vaizdas iš viršaus; $b$ - erdvinis vaizdas)

Fig. 2.11. A discrete model of the two-story three-dimensional frame (athe plane view; $b$ - the three-dimensional view)

2.4 lentelè. Analizuojamo rèmo apkrovimo variantai

Table 2.4 Load cases of the analysed frame

\begin{tabular}{|c|c|c|c|}
\hline $\begin{array}{c}\text { Apkrovos } \\
\text { variantas }\end{array}$ & $\begin{array}{c}\text { Vertikali } \\
\text { apkrova }\end{array}$ & $\begin{array}{c}\text { Horizontali apkrova } \\
H_{1}\end{array}$ & $\begin{array}{c}\text { Horizontali apkrova } \\
H_{2}\end{array}$ \\
\hline 1 & $P$ & $P / 5$ & $P / 10$ \\
\hline 2 & $P$ & $P / 4$ & $P / 8$ \\
\hline 3 & $P$ & $P / 3$ & $P / 6$ \\
\hline
\end{tabular}

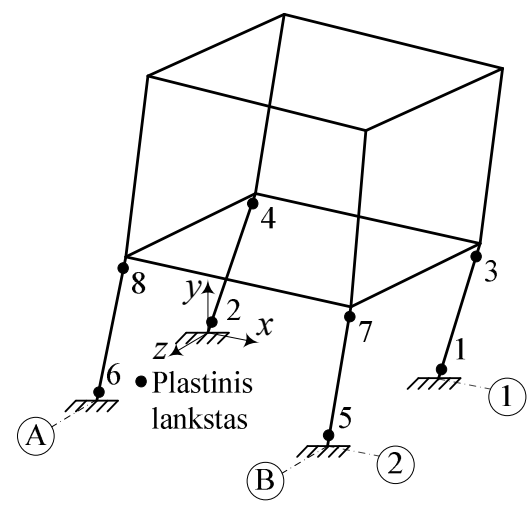

2.12 pav. Dviejų aukštų rèmo deformuotas vaizdas veikiant pirmo apkrovos varianto ribinei reikšmei

Fig. 2.12. The shape of the deformed two-story three-dimensional frame under the ultimate load of the first load case 


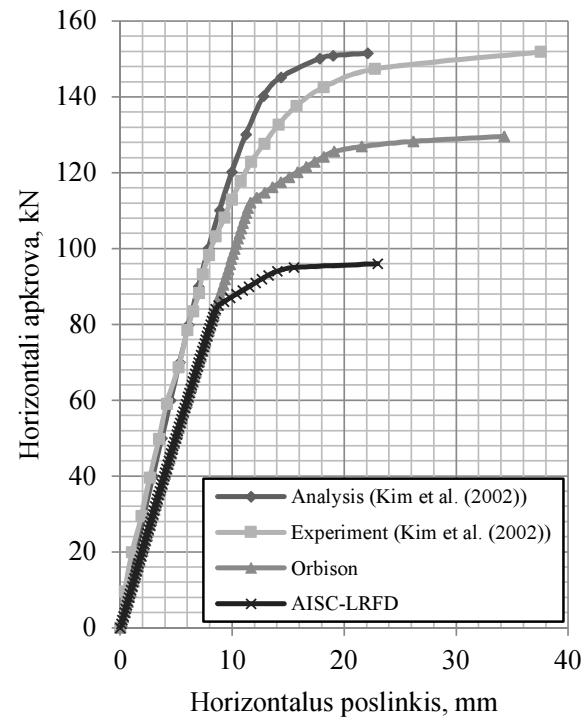

a)

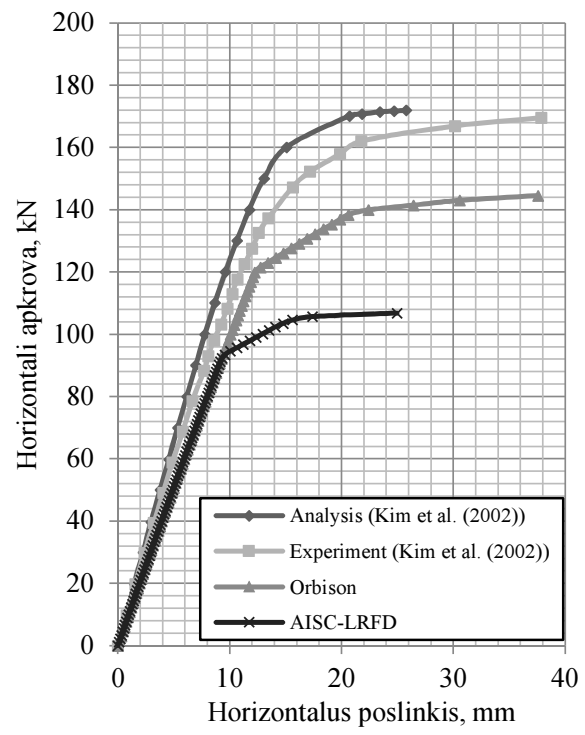

c)

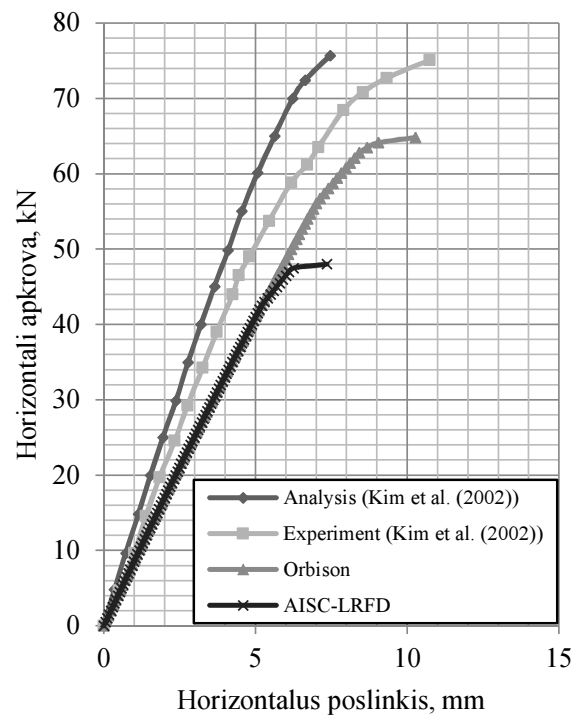

b)

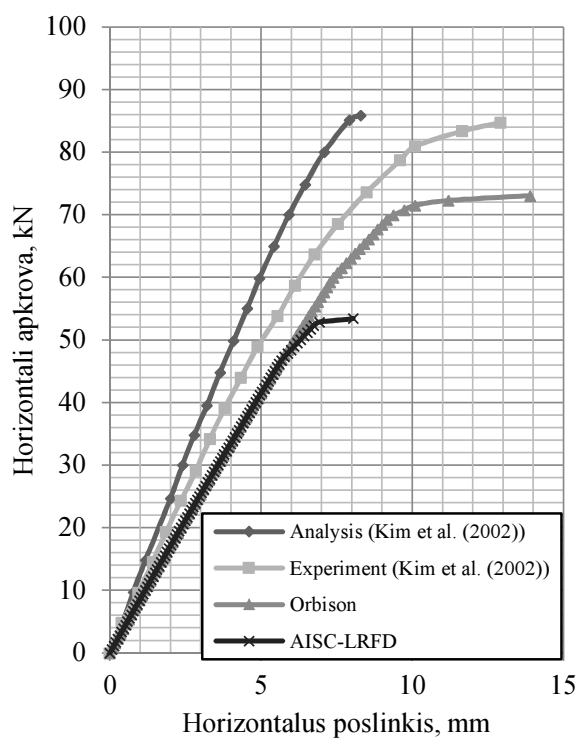

d)

2.13 pav. Apkrovos poslinkio kreivès A ir B mazgams pirmojo apkrovos varianto (a) ir (b) ir antrojo apkrovos varianto (c) ir (d) atveju

Fig. 2.13. Node A and B load-displacement curves under the first load case ((a) and (b) properly) and under the second load case ((c) and d) properly) 


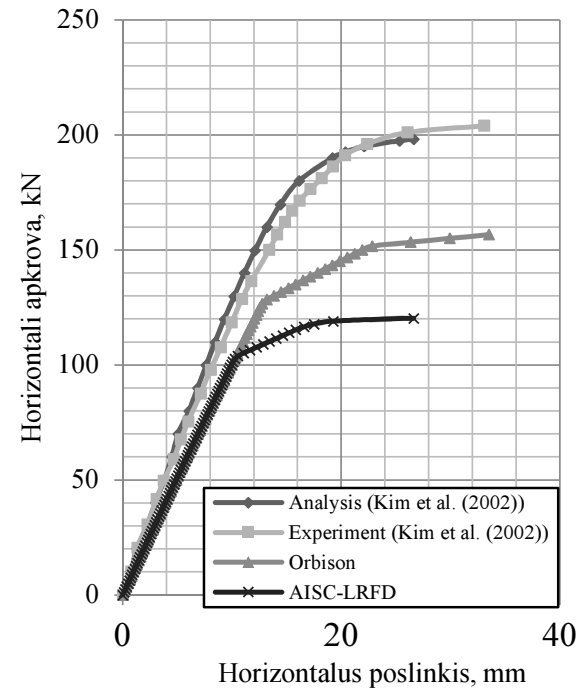

a)

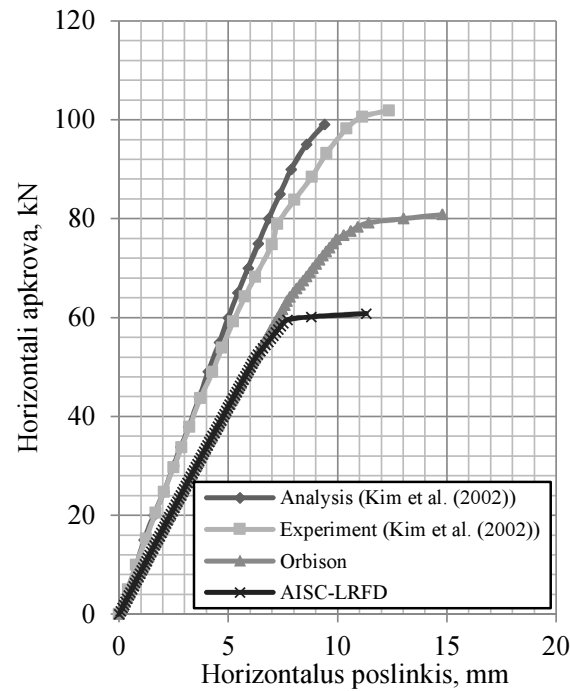

b)

2.14 pav. Apkrovos poslinkio kreivès A ir B mazgams trečiojo apkrovos varianto (a) ir (b) atveju

Fig. 2.14. Nodes A and B load-displacement curves under the third load case (a) and b) properly)

Kiekvienam apkrovos variantui buvo atlikta po du skaičiavimus. Pirmasis skaičiavimas buvo atliekamas taikant Orbison stiprumo (takumo) sąlygas (2.99), antrasis skaičiavimas buvo atliekamas taikant AISC-LRFD normatyvinio dokumento stiprumo (takumo) sąlygas (2.93) arba (2.98). Gauti dviejų aukštų analizès rezultatai buvo palyginti su rezultatais gautais Kim, Lee (2002) darbe. Plastinių lankstų susidarymo eiliškumas ir deformuoto rèmo vaizdas veikiant ribiniai apkrovai yra pateikti 2.12 paveiksle. Plastiniai lankstai iš pradžių susidaro kolonų elementuose esančiuose „1“ ašyje, prie atramų. Apkrovai didèjant plastiniai lankstai atsiranda šių elementų viršuje. Toliau plastiniai lankstai tokiu pačiu eiliškumu susidaro kolonose esančiose ašyje ,2“. Kadangi horizontalios apkrovos nèra simetrinès, elementuose susidaro sukimo ịrąžos ir pirmo aukšto kolonų elementai susisuka. Plastinių lankstų susidarymo eiliškumas priklausomai nuo veikiančiosios apkrovos didumo yra pateiktas 2.5 lentelëje. Čia duomenys yra pateikti pirmajam apkrovos variantui, pasirinkus ribinę $P$ reikšmę, kuri yra lygi 675 kN. Taškų $A$ ir $B$ apkrovų-poslinkių kreivès visiems apkrovos variantams yra parodytos 2.13 ir 2.14 paveiksluose.

Skaitinio eksperimento rezultatai parodè, kad rezultatai, gaunami taikant Orbison stiprumo (takumo) sąlygas (2.99), yra artimesni duomenims gautiems (Kim and Lee 2002) darbe. Didesnis nuokrypis buvo gautas, kai buvo taikomos AISC-LRFD normatyvinio dokumento stiprumo (takumo) sąlygos (2.93) arba 
(2.98). Šios sąlygos yra griežtesnès ir konservatyvesnès nei Orbison stiprumo (takumo) sąlygos. Tai galima paaiškinti tuo, kad AISC-LRFD yra projektavimą reglamentuojantis normatyvinis dokumentas. Tokiuose dokumentuose dažniausia priimama, kad konstrukcija dirba tampraus darbo ribose, kas užtikrina užsiduotą atsargos dydị. Apkrovų-poslinkių diagramų charakteriai ir jų palyginimas leidžia daryti išvadą, kad pagal konstrukcijos darbo duomenis, kurie gauti pagal aukščiau aprašytus tamprių plastinių geometriškai netiesinių rèmų analizès matematinius modelius, gaunami rezultatai yra labai artimi ankščiau kitų autorių atliktų darbų rezultatams.

2.5 lentelè. Dviejų aukštų rẻmo plastinių lankstų susidarymą atitinkančiu apkrovos faktorių palyginimas

Table 2.5. A comparison of plastic hinge load ratios for a two-story threedimensional frame

\begin{tabular}{|c|c|c|c|c|c|c|c|c|}
\hline $\begin{array}{c}\text { Lankstu } \\
\text { formavimosi } \\
\text { eiliškumas }\end{array}$ & 1 & 2 & 3 & 4 & 5 & 6 & 7 & 8 \\
\hline $\begin{array}{c}\text { Apkrovos } \\
\text { faktorius } \\
\text { (AISC-LRFD) }\end{array}$ & 0,423 & 0,432 & 0,514 & 0,530 & 0,543 & 0,562 & 0,666 & 0,681 \\
\hline $\begin{array}{c}\text { Apkrovos } \\
\text { faktorius } \\
\text { (Orbison) }\end{array}$ & 0,740 & 0,754 & 0,822 & 0,889 & 0,918 & 0,943 & 0,945 & 0,965 \\
\hline
\end{tabular}

Ribinių apkrovų reikšmių skaičiavimų rezultatai yra pateikti 2.6 lentelèje. Skirtumas tarp analizès uždavinio skaičiavimo taikant Orbisono stiprumo (takumo) sąlygas ir (Kim and Lee 2002) darbe pateiktų rezultatų sudare nuo $13,5 \%$ iki 21,5\%. Taikant AISC-LRFD normatyviniu dokumentų stiprumo (takumo) sąlygas - nuo 36,8 \% iki 41,1\%. Tokie rezultatų skirtumai susidare dèl to, kad (Kim et al. 2002) darbe yra labai tiksliai įvertinti visi nagrinejjamų plieno profilių geometrijos netikslumai ir fizinių parametrų skirtumai. Pavyzdžiui, takumo ribos vertikaliems elementams (Kim and Lee 2002) darbe yra pasirinktos tokios: skerspjūvio lentynų - $320 \mathrm{MPa}$, sienelès - $311 \mathrm{MPa}$. Horizontaliems elementams: lentynoms - $344 \mathrm{MPa}$, sienelèms $327 \mathrm{MPa}$. Šiame darbe pasirinktas idealizuotas konstrukcijos diskretinis modelis. Plieno profiliu geometriniai ir fiziniai parametrai išlieka pastovūs per visą konstrukcijos elemento ilgị.

Pasirinktos konstrukcijos tampri plastiné analizė buvo atlikta pritaikius kompiuterinio matematinio skaičiavimo komplekso MATLAB optimizavimo uždavinių skaičiavimų paprogramę Optimization Toolbox. Skaitinio eksperimento komandinès bylos tekstas, sudarytas pagal MATLAB programavimo kalbos dèsningumus, yra pateiktas $\mathrm{C}$ priede. 
2.6. lentelè. Jègų ribinès reikšmès $A$ ir $B$ mazguose

Table 2.6. The limit forces values at $A$ and $B$ nodes

\begin{tabular}{|c|c|c|c|c|}
\hline \multirow[b]{2}{*}{ 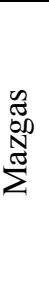 } & \multicolumn{2}{|c|}{$\begin{array}{l}\text { (Kim, Lee 2002) darbo rezultatu } \\
\text { duomenys }\end{array}$} & \multicolumn{2}{|c|}{$\begin{array}{l}\text { Siūlomo matematinio modelio } \\
\text { skaičiavimų rezultatų duomenys }\end{array}$} \\
\hline & $\begin{array}{c}\text { Realios } \\
\text { konstrukcijos } \\
\text { bandymas }\end{array}$ & $\begin{array}{l}\text { ABAQUS } \\
\text { skaičiavimo } \\
\text { rezultatai }\end{array}$ & $\begin{array}{l}\text { Orbison stiprumo } \\
\text { (takumo) sąlygos }\end{array}$ & $\begin{array}{c}\text { AISC- } \\
\text { LRFD } \\
\text { stiprumo } \\
\text { (takumo) } \\
\text { sąlygos }\end{array}$ \\
\hline \multicolumn{5}{|c|}{ I apkrovos variantas } \\
\hline$A$ & $151,8 \mathrm{kN}$ & $151,5 \mathrm{kN}$ & $130,0 \mathrm{kN}$ & $95,0 \mathrm{kN}$ \\
\hline$B$ & $75,1 \mathrm{kN}$ & $75,7 \mathrm{kN}$ & $65,0 \mathrm{kN}$ & $47,5 \mathrm{kN}$ \\
\hline \multicolumn{5}{|c|}{ II apkrovos variantas } \\
\hline$A$ & $169,5 \mathrm{kN}$ & $171,9 \mathrm{kN}$ & $144,5 \mathrm{kN}$ & $106,8 \mathrm{kN}$ \\
\hline$B$ & $84,7 \mathrm{kN}$ & $85,8 \mathrm{kN}$ & $73,0 \mathrm{kN}$ & $53,4 \mathrm{kN}$ \\
\hline \multicolumn{5}{|c|}{ III apkrovos variantas } \\
\hline$A$ & $204,0 \mathrm{kN}$ & $198,1 \mathrm{kN}$ & $160,0 \mathrm{kN}$ & $120,0 \mathrm{kN}$ \\
\hline$B$ & $99,1 \mathrm{kN}$ & $101,9 \mathrm{kN}$ & $80,0 \mathrm{kN}$ & $60,0 \mathrm{kN}$ \\
\hline
\end{tabular}

\subsection{Antrojo skyriaus išvados}

1. Irodyta, kad matematinio programavimo teorijos ir mechanikos ekstreminių energinių principų junginys yra efektyvus nustatant tikraji İDB. Šio modelio realizavimas suvedamas $i$ vienintelio ekstremumo suradimą nenagrinejjant plastinių lankstų susidarymo bei pradinio diskretinio modelio geometrijos pasikeitimų.

2. Apskaičiuotas sijos ịlinkis panaudojant sukurtą analizès uždavinio matematini modeli yra lygus $18,56 \mathrm{~cm}$ ir sutampa su etapiniu daug pastangų reikalaujančiu metodu. Tuo tarpu gauta ribinès apkrovos reikšmé yra $9 \%$ didesnè.

3. Gautieji geometriškai netiesinès netamprios plastinès erdvinès konstrukcijos įrąžu ir poslinkių rezultatai palyginti su rezultatais gautais ABAQUS konstrukcijų analizés programa ir su eksperimentiniais realios konstrukcijos bandymo rezultatais. Taikant AISC-LRFD normatyviniu dokumentų reglamentuojamas stiprumo sąlygas konstrukcijų analizei, ribinės apkrovos reikšmès nuokrypis nuo reikšmių gautų konstrukciją modeliuojant ABAQUS programa bei atlikus realios konstrukcijos eksperimentinị bandymą, sudare iki $41 \%$, o taikant Orbison stiprumo (takumo) sąlygas, nuokrypis sudare apie $21 \%$. Todèl tolimesniems skaičiavimams buvo pasirenkamos Orbison stiprumo sąlygos. 



\section{Konstrukcijų optimizavimo uždavinys ribojant poslinkius}

Skyriuje pateiktas pasiūlyto algoritmo trečiasis skaičiavimas-pakopa konstrukcijos elementų skerspjūvių plotų optimizavimo uždavinys ribojant poslinkius. Pristatoma originali metodika tikrujų konstrukcijos poslinkių apskaičiavimui. Pateikti skaičiavimai, kurie turi būti atlikti siekiant, kad konstrukcijos optimizavimo matematinio modelio panaudojimas būtų efektyvus, o gautų rezultatų konvergencija tiksli ir greita. Pateikiamas detalus pirmajame skyriuje pasiūlyto algoritmo vaizdas. Siūlomų metodikų efektyvumas pagrindžiamas skaitinio eksperimento rezultatais.

Skyriaus tematika paskelbtas vienas straipsnis (Popov et al. 2013). Rezultatai buvo pristatyti dvejose tarptautinèse mokslinèse konferencijose - „Optimization and Analysis of Structures“ 2011 m. Tartu, Estijoje, bei „Задачи и методы компьютерного моделирования конструкиий и сооружений“ (,, Золотовские чтения “) vykusioje 2013 m. Maskvoje, Rusijoje. 


\subsection{Optimizavimo uždavinio ribojant poslinkius matematinis modelis}

Konstrukcijos optimizavimo uždavinys ribojant poslinkius sprendžiamas atlikus dviejų pirmųų siūlomo optimizavimo algoritmo pakopų, pristatytų antrajame skyriuje, skaičiavimus. Kitaip tariant, turint pilną informaciją apie konstrukcijos tikraji İDB, veikiant pasirinktai apkrovai.

Konstrukcijų optimizavimo uždavinio ribojant poslinkius bendras matematinis modelis užrašomas tokia išraiška:

Rasti

$$
\begin{gathered}
\min V\left(A_{k}\right), \\
\mathbf{f}\left(\mathbf{S}, \mathbf{S}_{0}\left(A_{k}\right)\right) \leq \mathbf{1}, \\
u_{t}^{-} \leq u_{t}\left(A_{k}\right) \leq u_{t}^{+}, \\
A_{k} \geq A_{k}^{\min }, \\
t=1,2, \ldots, m_{t}, k=1,2, \ldots, s,
\end{gathered}
$$$$
\text { kai }
$$

čia $V$ - bendras suminis konstrukcijos elementų sudaromas tūris; $A_{k}-$ konstrukcijos $k$-osios grupès elementų skerspjūvio plotas; $u_{t}$ - skaičiuotinis konstrukcijos mazgo poslinkis $t$-aja kryptimi; $u_{t}^{-}$ir $u_{t}^{+}-$skaičiuotinès konstrukcijos mazgo poslinkio $t$-ajja kryptimi apatine ir viršutine riba; $A_{k}^{\min }-$ konstrukcijos $k$-osios grupès elementų skerspjūvio ploto apatinè riba; $m_{t}-$ ribojamų poslinkių skaičius; $s$ - konstrukcijos elementų skerspjūvių grupių skaičius.

Optimizavimo uždavinys (3.1)-(3.4) yra iškilas netiesinio matematinio programavimo uždavinys, turintis tik vieną ekstremumą (Karkauskas et al. 2009).

Galimi leistinos projektavimo srities bei sprendimo atvejai, kai yra du optimizuojami parametrai bei stiprumo sąlygos, išreikštos tiesinemis funkcijomis (pavyzdžiui (2.93)), yra parodyti 3.1 ir 3.2 paveiksluose (Karkauskas et al. 2004).

3.1 paveiksle pavaizduotas optimalus sprendinys, kai poslinkiu ribojimo sąlyga yra neaktyvi. Leistinujų sprendinių sritis yra tiesinè. Optimizaciją apsprendžia konstrukcijos elementų stiprumo arba stabilumo sąlygos.

3.2 paveiksle pavaizduota leistinų sprendimų sritis, sudaryta ne vien tik iš stiprumo arba stabilumo sąlygų, bet taip pat ir iš poslinkių ribojimo sąlygų, kurios yra netiesinès. Šiuo atveju bent viena stiprumo sąlyga ir poslinkių apribojimų sąlyga optimalaus sprendinio taške turi būti patenkinta kaip lygybè. 


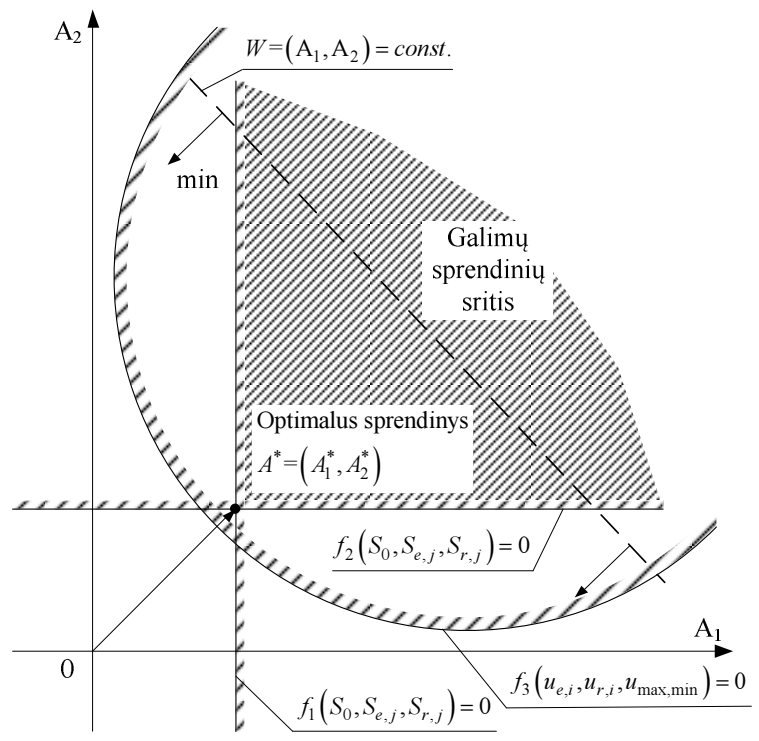

3.1 pav. Optimizavimo uždavinio leistinų sprendinių sritis apribota tiesėmis Fig. 3.1. The optimization problem feasible solutions' area bounded by lines

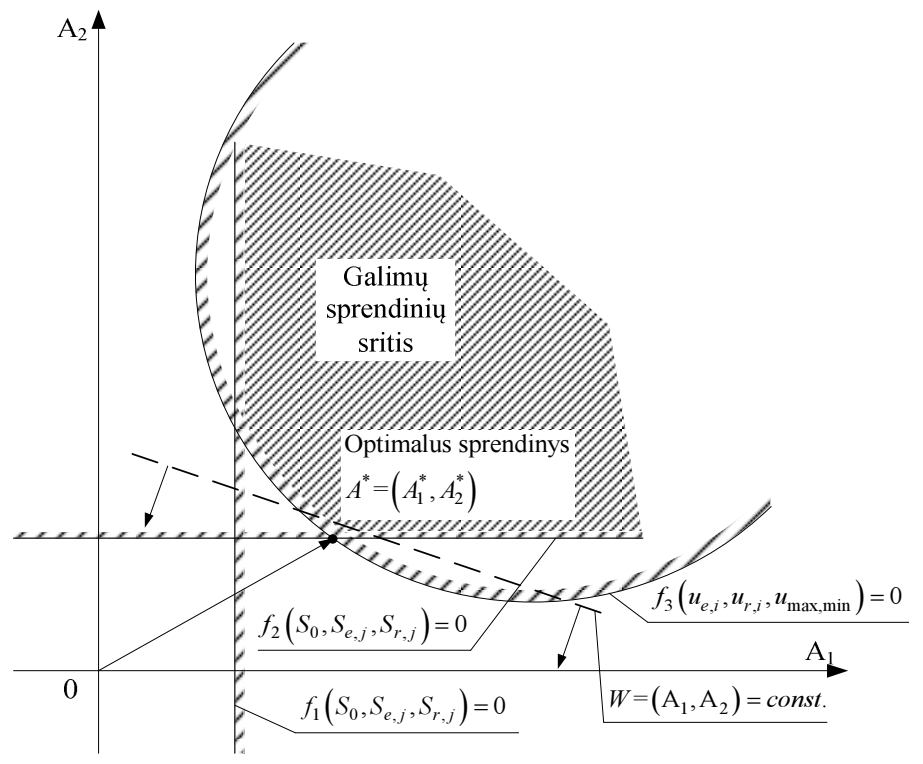

3.2 pav. Optimizavimo uždavinio leistinų sprendinių sritis yra netiesinė Fig. 3.2. The optimization problem feasible solutions' area is nonlinear 
Matematiniame modelyje (3.1)-(3.4) sąlygos (3.2) yra stiprumo sąlygos, kurios yra plačiai aptartos 2 skyriuje.

Efektyviam optimizavimo uždavinio (3.1)-(3.4) matematinio modelio panaudojimui ir siekiant gauti greitą sprendimo konvergenciją turi būti atlikti keturi svarbūs paruošiamieji skaičiavimai. Jie aprašomi tolesniuose disertacinio darbo skyriuose. Šios konvergencijos metodikos buvo sėkmingai pritaikytos skaičiuojant plokščias geometriškai tiesines konstrukcijas, pritaikymo rezultatai plačiai apžvelgti Atkočiūnas et al. 2010 darbe. Šios metodikos taikytinos ir netiesinių skaičiavimų atveju.

\subsection{Konstrukcinių apribojimų parinkimas}

Pirmasis iš aukščiau paminètų skaičiavimų - konstrukcinių apribojimų (3.4) skerspjūvių plotų apatinių ribų $A_{k}^{\text {min }}$ parinkimas. Tai galima padaryti išsprendus konstrukcijos optimizavimo uždavini plastiškosios suirties etape, kurio matematinis modelis užrašomas taip:

Rasti

$$
V\left(A_{k}^{\min }\right) \rightarrow \min
$$

kai

$$
\begin{aligned}
& \mathbf{f}\left(\mathbf{S}_{e}, \mathbf{S}_{r}, \mathbf{S}_{0}\left(A_{k}^{\min }\right)\right) \leq \mathbf{1}, \\
& \mathbf{A}_{n} \mathbf{S}_{r}=\mathbf{F}-\mathbf{A}_{n} \mathbf{S}_{e}, \\
& A_{k}^{\min } \geq \mathbf{0}, k=1,2, \ldots, s .
\end{aligned}
$$

Šis uždavinys sprendžiamas iteraciniu būdu. Sprendimo algoritmas yra pateiktas 3.3 paveiksle. (3.1)-(3.4) uždavinio sprendimui, (3.5) uždavinio rezultatas yra taikomas, padauginus ji iš koeficiento 1,01 , kitaip tariant paimamos optimizuojamų parametrų (šiuo atveju konstrukcijos elementų skerspjūvių plotų) reikšmès prieš pat konstrukcijos plastini suirimą.

\subsection{Poslinkių kitimo ribų parinkimas}

Sekantis svarbus skaičiavimas, kuris turi būti atliktas prieš sprendžiant (3.1)-(3.4) optimizavimo uždavini yra poslinkių (3.3) apribojimų apatinių $u_{t}^{-}$ir viršutinių $u_{t}^{+}$ribų nustatymas. Čia sprendžiama keletas uždavinių, sujungiančių 1 ir 2 siūlomo optimizavimo algoritmo sprendimo pakopas (plačiai pristatytas 2 skyriuje). Panaudojant (3.5) optimizavimo uždavinio rezultatą $-A_{k}^{\min }$ ir redukuotą apkrovos vektorių $\tilde{\mathbf{F}}=\gamma_{\text {red }} \mathbf{F}$, (čia $\gamma_{\text {red }}$ yra apkrovos redukcijos 
koeficientas, artimas vienetui, bet ne didesnis) yra nustatomos poslinkių viršutinės apribojimų ribos $\mathbf{u}_{\max }=\mathbf{u}_{e}+\mathbf{u}_{r}$, konstrukcijai esant prieš pat plastinį suirimą:

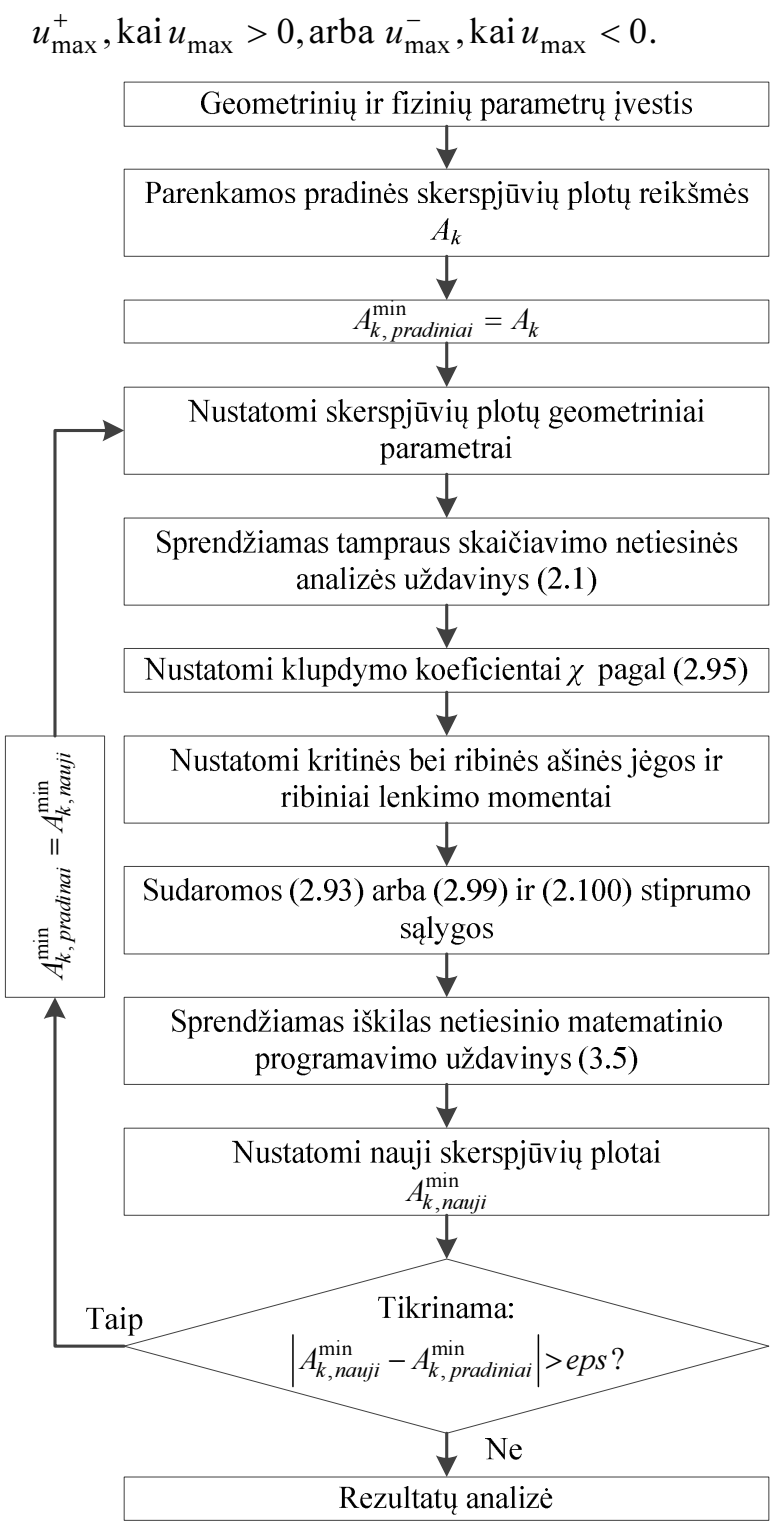


Toliau apskaičiuojami poslinkiai, kai konstrukcijoje susidaro pirmasis plastinis lankstas. Šie poslinkiai gaunami mažinant apkrovos redukcijos koeficientą ir sprendžiant 1 ir 2 siūlomo optimizavimo algoritmo sprendimo pakopų uždavinius. Gautos reikšmès yra apatinès poslinkių apribojimų reikšmès. $\mathbf{u}_{\min }=\mathbf{u}_{e}+\mathbf{u}_{r}$ yra poslinkiai atitinkantys tamprujį atsaką:

$$
u_{\min }^{+}, \operatorname{kai} u_{\min }>0 \text {, arba } u_{\min }^{-}, \operatorname{kai} u_{\min }<0 .
$$

Svarbu paminèti, kad (3.1)-(3.4) optimizavimo uždaviniui parinkti poslinkiu apribojimų sąlygų dydžiai $u_{t}^{-}$ir $u_{t}^{+}$turi patekti tarp šių ribinių reikšmių:

$$
\begin{aligned}
& \text { kai } \mathbf{u}^{+}>0 \text {, tai } \mathbf{u}_{\text {min }}^{+} \leq \mathbf{u}^{+} \leq \mathbf{u}_{\text {max }}^{+}, \\
& \text {kai } \mathbf{u}^{-}<0 \text {, tai } \mathbf{u}_{\min }^{-} \geq \mathbf{u}^{-} \geq \mathbf{u}_{\max }^{-} \text {. }
\end{aligned}
$$

Tokiu būdu nustatyti poslinkių apribojimai užtikrina konstrukcijos darbą, esant tampriai plastinei būsenai ir optimizacija atliekama pagal (3.1)-(3.4). Jei šie apribojimai yra pažeisti, optimizavimo uždavinys neturi sprendinio.

\subsection{Optimizavimo uždavinio ribojant poslinkius pradinio taško parinkimas}

Trečiasis aukščiau minètas skaičiavimas yra pradinių skerspjūvių plotų dydžių parinkimas optimizavimo uždaviniui (3.1)-(3.4). Čia sprendžiama keletas uždavinių, apjungiančių pirmą ir antrą siūlomo optimizavimo algoritmo sprendimo pakopas (plačiai pristatytas 2 skyriuje), tokiu būdu keičiamos $A_{k, \text { start }}$ reikšmès, kol galiausiai gautos poslinkių reikšmès yra didesnès už tampraus atsako poslinkius ir mažesnès už poslinkius konstrukcijai esant prieš pat plastinị suirimą, tai yra turi tenkinti šias nelygybes:

$$
\begin{aligned}
& \text { kai } \mathbf{u}>0, \text { tai } \mathbf{u}_{\min }^{+} \leq \mathbf{u} \leq \mathbf{u}_{\max }^{+}, \\
& \text {kai } \mathbf{u}<0, \text { tai } \mathbf{u}_{\min }^{-} \geq \mathbf{u} \geq \mathbf{u}_{\max }^{-} .
\end{aligned}
$$

\subsection{Poslinkių skaičiavimas}

Ketvirtasis skaičiavimas - tai nustatyti tikrujų poslinkių, priklausančių nuo optimizuojamų parametrų - konstrukcijų elementų skerspjūvių plotų, reikšmes (3.3) poslinkių apribojimams. Šie poslinkiai yra nustatomi iteracinio skaičiavimo metu naudojant rezultatus gautus pirmų dviejų pakopų-uždavinių sprendimo metu. Konstrukcijos poslinkiai $t$-aja kryptimi apskaičiuojami pagal formulę: 


$$
u_{t}=\sum_{k=1}^{s} \mathbf{u}_{t, k} \tilde{\mathbf{k}}_{\tau, k} \overline{\mathbf{u}}_{t, k}
$$

čia $\mathbf{u}_{t, k}$ yra $k$-ojo elemento mazginių taškų tikrujų globalių poslinkių vektorius $t$ aja kryptimi, gautas atlikus tampraus skaičiavimo netiesinès analizès (2.1) ir geometriškai netiesinių tamprių plastinių konstrukcijų analizès ((2.77) arba (2.82)) uždavinių skaičiavimus; $\tilde{\mathbf{k}}_{\tau, k}$ yra elemento tangentinè standumo matrica, jungianti ieškomus skerspjūvių plotus $A_{k} ; \overline{\mathbf{u}}_{t, k}$ yra $k$-ojo elemento globaliujju poslinkių vektorius, apskaičiuotas nuo vienetinès jègos, pridètos ribojamo poslinkio kryptimi.

Svarbu paminèti, kad (3.10) konstrukcijos globalinè standumo matrica sudaroma iš atskirų baigtinių elementų tangentinių standumo matricų $\tilde{\mathbf{k}}_{\tau, k}$, ¡ंvertinus visus pradinės konstrukcijos pasikeitimus pagal tikraji İDB nuo pasirinktos apkrovos (keičiamas konstrukcijos diskretinis modelis, papildant ji susidariusiais plastiniais lankstais, bei keičiamos pradinės konstrukcijos mazgų koordinatės). Poslinkių vektorius $\overline{\mathbf{u}}_{t, k}$ apskaičiuojamas, ivvertinus visus aukščiau minètus pasikeitimus konstrukcijoje pagal tikraji İDB. Tokiu būdu aprašyta tikrụju poslinkių nustatymo procedūra leidžia (3.10) formulès dešinèje pusëje, pagrindinius uždavinio (3.1)-(3.4) nežinomuosius $A_{k}$ išskirti kaip atskirus daugiklius.

\subsection{Optimizavimo uždavinio sprendimo išplèstinis algoritmas}

Sujungiant visus aukščiau aptartus skaičiavimus siūlomas optimizavimo uždavinio (1.7) sprendimo algoritmas, pavaizduotas 1.3 paveiksle, gali būti išplèstas, kaip tai yra parodyta 3.4 paveiksle.

\subsection{Skaitinè realizacija}

Optimizavimo uždavinio skaičiavimui sukurto algoritmo (3.4 pav.) galimybes atskleisime optimizuodami šešių aukštų erdvinio plieninio remo, pateikto 3.5 paveiksle, strypų skerspjūvių parametrus.

Nagrinejjamo rèmo geometrija, pridètų vertikalių ir horizontalių jègų pasiskirstymas yra pateiktas 3.5 paveiksle: $V_{1}=64,229 \mathrm{kN}, V_{2}=128,457 \mathrm{kN}$ ir $H_{1}=53,376 \mathrm{kN}$. Konstrukcijos elementu skerspjūvių plotai yra suskirstyti i 6 grupes (3.5 pav.). Visų trijų pirmų aukštų kampinių kolonų skerspjūvio plotas yra $A_{1}$. 


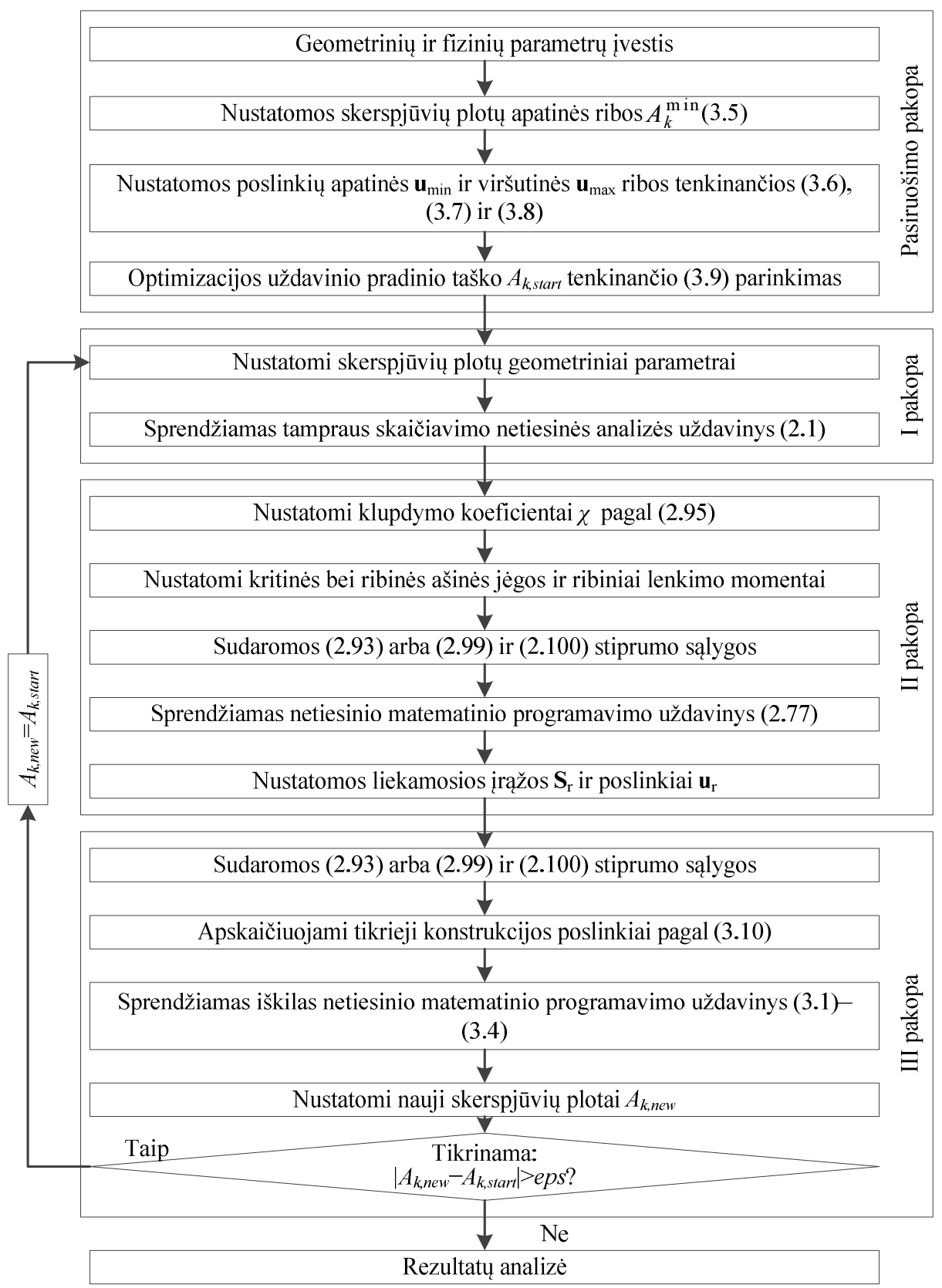

3.4 pav. Siūlomo optimizavimo uždavinio sprendimo išplèstinis algoritmas Fig. 3.4. The extensive suggesting solution algorithm of optimization problem 


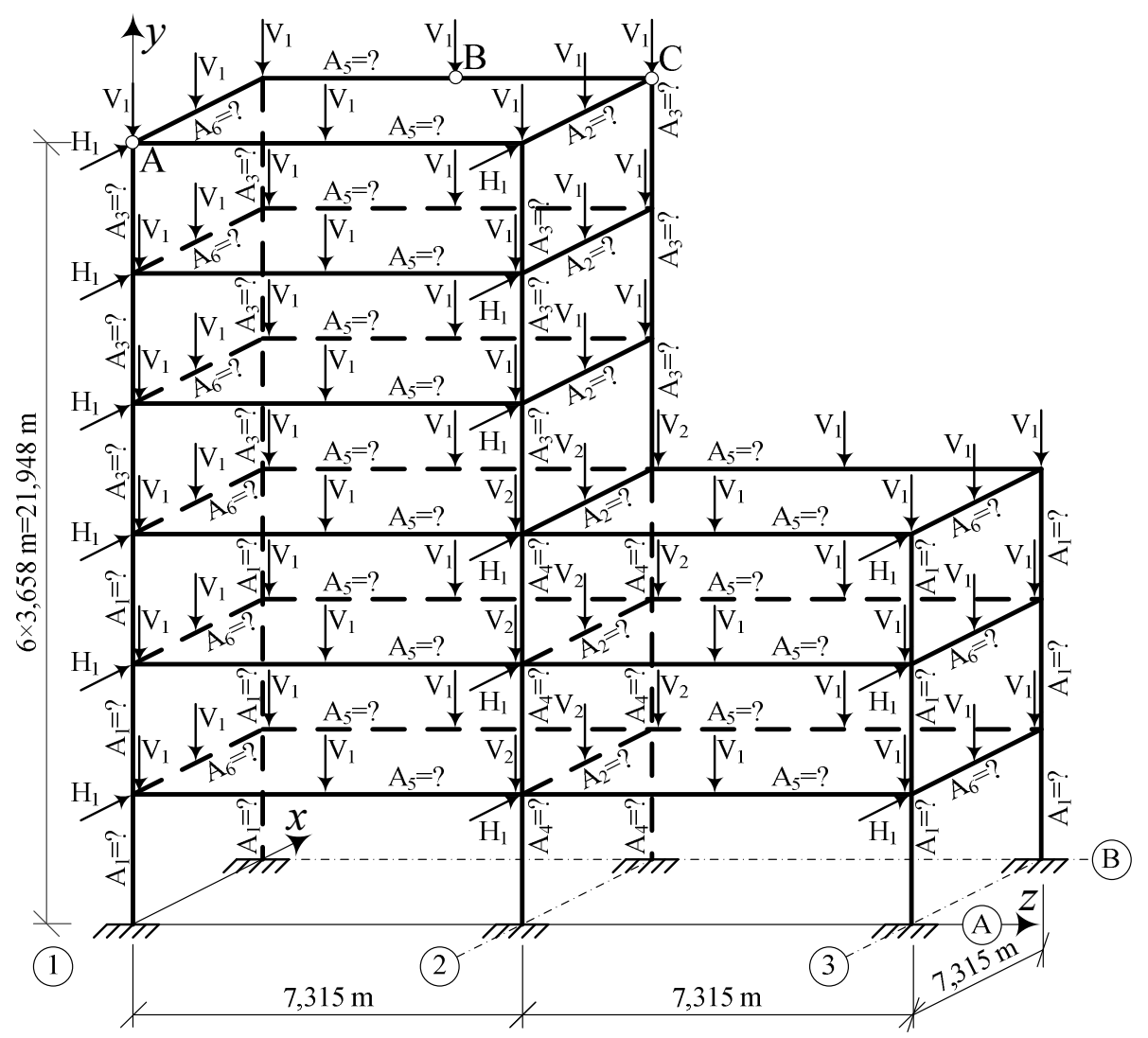

3.5 pav. Šešių aukštų erdvinis rèmas

Fig. 3.5. The six-story three-dimensional frame

Visų sijų esančių „2“ ašyje skerspjūvio plotas yra $A_{2}$. Ketvirto, penkto ir šešto aukštų kampinių kolonų skerspjūvio plotas yra $A_{3}$. Visų trijų pirmų aukštų kolonų esančių „2" ašyje skerspjūvio plotas yra $A_{4}$. Visų sijų lygiagrečių , $x^{\prime \prime}$ ašiai skerspjūvio plotas yra $A_{5}$. Visų kraštinių sijų lygiagrečiu , , $z^{\text {“ }}$ ašiai skerspjūvio plotas yra $A_{6}$.Nagrinèjamo rèmo geometrija, pridètų vertikalių ir horizontalių jëgų pasiskirstymas yra pateiktas 3.5 paveiksle: $V_{1}=64,229 \mathrm{kN}, V_{2}=128,457 \mathrm{kN}$ ir $H_{1}=53,376 \mathrm{kN}$. Konstrukcijos elementu skerspjūviu plotai yra suskirstyti i 6 grupes (3.5 pav.). Visų trijų pirmų aukštų kampinių kolonų skerspjūvio plotas yra $A_{1}$. Visų sijų esančių „2“ ašyje skerspjūvio plotas yra $A_{2}$. Ketvirto, penkto ir šešto aukštų kampinių kolonų skerspjūvio plotas yra $A_{3}$. Visų trijų pirmų aukštų kolonų esančių „2" ašyje skerspjūvio plotas yra $A_{4}$. Visų sijų lygiagrečių , $x^{\prime \prime}$ ašiai skerspjūvio plotas yra $A_{5}$. Visų kraštinių sijų lygiagrečiu ,,$z^{“}$ ašiai skerspjūvio plotas yra $A_{6}$. 
Mazgo „A“(3.5 pav.) poslinkis teigiama $x$ ašies kryptimi neturi viršyti $19 \mathrm{~cm}$ bei mazgo „B“ (3.5 pav.) poslinkis neigiama $y$ ašies kryptimi neturi viršyti $5,5 \mathrm{~cm}$.

Rèmo medžiagos (plieno) fiziniai parametrai - takumo riba $f_{u}=250 \mathrm{MPa}$, tamprumo modulis $E=206,85 \mathrm{GPa}$.

Rèmo diskretinị modelị, pateiktą 3.5 paveiksle, sudaro 69 mazgai, turintys 378 laisvumo laipsnius, ir dviejų tipų elementai - 30 kolonų tipo elementų ir 66 sijinio tipo elementai. Visi elementai konstrukcijoje yra vertinami kaip tempiami, gniuždomi, sukami bei lenkiami dvejose ašyse. Tokiu būdu, bendras įrąžų skaičius yra 576.

3.1 lentelè. „W“ tipo profilių geometrinių rodiklių santykio koeficientai

Table 3.1. Relation coefficients of geometrical parameters for $\mathrm{W}$ profiles

\begin{tabular}{|c|c|c|}
\hline $\begin{array}{c}\text { Skerspjūvio } \\
\text { geometriniai } \\
\text { rodikliai }\end{array}$ & Koeficientas $a$ & Koeficientas $b$ \\
\hline$I_{y}$ & 5,0783 & 1,8281 \\
\hline$I_{z}$ & 0,5567 & 1,7919 \\
\hline$I_{t}$ & 0,0025 & 2,2255 \\
\hline$W_{p l, y}$ & 2,1162 & 1,4142 \\
\hline$W_{p l, z}$ & 0,4960 & 1,4101 \\
\hline$W_{t}$ & 0,0302 & 1,5856 \\
\hline$W_{e, y}$ & 1,9757 & 1,4015 \\
\hline$W_{e, z}$ & 0,3239 & 1,4078 \\
\hline
\end{tabular}

Siūlomo optimizavimo algoritmo skaitinei realizacijai reikalingas santykis tarp elementų skerspjūvio ploto ir kitų elementų skerspjūvių geometrinių parametrų (Atkočiūnas et al. 2010):

$$
Z_{k}=a A_{k}^{b},
$$

čia $Z_{k}-$ konstrukcijos $k$-osios grupès elementu skerspjūvių geometrinis parametras (inercijos momentas, plastinis atsparumo momentas ir pan.); $a$ ir $b$ yra santykio koeficientai.

Rèmas yra projektuojamas iš „W“ tipo dvitejjiu profiliuočių, atitinkančių Amerikos standartą (ASTM Standard A6/A6M). Siu profiliuočių geometrinių parametrų santykių koeficientai, apskaičiuoti pagal (3.11) formulę, yra pateikti 3.1. lentelèje.

Trumpai aptarsime optimizuojamo rèmo konstrukcijos deformatyvumo apribojimus. Optimizuojamų parametrų - skerspjūvių plotų - apatines ribas gauname rèmo optimizavimo prie plastinio suirimo uždavinio (3.5) sprendinio. 
3.2 lentelè. Šešių aukštų erdvinio rèmo optimizavimo prie konstrukcijos plastinio suirimo uždavinio rezultatai

Table 3.2. Six story space frame optimization prior to structure's plastic collapse problem results

\begin{tabular}{|c|c|c|c|c|c|c|c|}
\hline Iteracija & $A_{1}, \mathrm{~cm}^{3}$ & $A_{2}, \mathrm{~cm}^{3}$ & $A_{3}, \mathrm{~cm}^{3}$ & $A_{4}, \mathrm{~cm}^{3}$ & $A_{5}, \mathrm{~cm}^{3}$ & $A_{6}, \mathrm{~cm}^{3}$ & $V, \mathrm{~m}^{3}$ \\
\hline 0 & 100,0000 & 100,0000 & 100,0000 & 100,0000 & 100,0000 & 100,000 & 3,51168 \\
\hline 1 & 113,2130 & 120,9100 & 69,6722 & 128,3110 & 30,2495 & 112,9014 & 2,7569 \\
\hline 2 & 145,3833 & 112,4464 & 82,7808 & 165,2700 & 29,7222 & 104,4194 & 2,9368 \\
\hline$\ldots$ & $\ldots$ & $\ldots$ & $\ldots$ & $\ldots$ & $\ldots$ & $\ldots$ & $\ldots$ \\
\hline 5 & 136,9136 & 112,5021 & 95,2354 & 154,8109 & 29,4146 & 105,5109 & 2,9347 \\
\hline 6 & 135,2542 & 112,5077 & 96,5649 & 153,6516 & 29,4167 & 105,7227 & 2,9322 \\
\hline 7 & 135,8320 & 112,4600 & 96,7482 & 153,9854 & 29,4263 & 105,5612 & 2,9351 \\
\hline
\end{tabular}

Rezultatas, pagal pasirinktą $0,1 \%$ optimalumo kriterijaus tikslumą, buvo pasiektas po 7 iteracijų. Skerspjūvių reikšmių kitimo dinamika ir galutinis rezultatas yra pateikti 3.2 lenteleje. Esant konstrukcijos elementų skerspjūvių plotų reikšmėms pateiktoms eiluteje pažymètoje numeriu , $7^{\text {“ }}$ ir apkrovos redukcijos faktoriui $\gamma_{\text {red }}=0,99$ yra sprendžiamos siūlomo optimizavimo uždavinio sprendimo algoritmo dvi pirmosios pakopos ir nustatomos rèmo poslinkių viršutinès ribos (poslinkių dydžiai, kai prasideda konstrukcijos plastinis irimas):

taško „A“ horizontalus poslinkis $x$ ašies teigiama kryptimi (3.5 pav.)

$$
u_{A, x, \max }=u_{e A, x}+u_{r A, x}=17,7310+5,3355=23,0665 \mathrm{~cm},
$$

taško „B“ vertikalus poslinkis $y$ ašies neigiama kryptimi (3.5 pav.)

$$
u_{B, y, \max }=u_{e B, \mathrm{y}}+u_{r B, \mathrm{y}}=-4,8489-2,0112=-6,8601 \mathrm{~cm} .
$$

Sumažinę apkrovos faktoriu $\gamma_{\text {red }}=0,8$ ir išsprendę siūlomo optimizavimo uždavinio sprendimo algoritmo dvi pirmąsias pakopas, nustatome poslinkių reikšmes, atitinkančias rèmo pirmojo plastiškojo lanksto susidarymą:

$$
\begin{aligned}
& u_{A, x, \min }=u_{e A, x}+u_{r A, x}=14,1062+0,1946=14,3008 \mathrm{~cm}, \\
& u_{B, y, \min }=u_{e B, y}+u_{r B, y}=-3,8614-0,0087=-3,8701 \mathrm{~cm} .
\end{aligned}
$$

Tai yra rèmo poslinkių kitimo apatinès ribos. Taigi uždavinio sąlygose priimtos mazgų poslinkių kitimo ribos yra tarp šių kraštinių ribų:

$$
\begin{aligned}
& 14,3008 \mathrm{~cm}<u_{A, x}=19 \mathrm{~cm}<23,0665 \mathrm{~cm}, \\
& -3,8701 \mathrm{~cm}<u_{B, y}=-5,5 \mathrm{~cm}<-6,8601 \mathrm{~cm},
\end{aligned}
$$

ir tai užtikrina konstrukcijos tamprų-plastinį darbą. 
3.3 lentelè. Šešių aukštų erdvinio rèmo optimizavimo uždavinio sprendimas naudojant siūlomą algoritmą

Table 3.3. The Six-story three-dimensional frame optimization problem solution by suggesting algorithm

\begin{tabular}{|c|c|c|c|c|c|c|c|}
\hline Iteracija & $A_{l}, \mathrm{~cm}^{3}$ & $A_{2}, \mathrm{~cm}^{3}$ & $A_{3}, \mathrm{~cm}^{3}$ & $A_{4}, \mathrm{~cm}^{3}$ & $A_{5}, \mathrm{~cm}^{3}$ & $A_{6}, \mathrm{~cm}^{3}$ & $V, \mathrm{~m}^{3}$ \\
\hline 0 & 142,6236 & 134,7665 & 104,2538 & 161,6846 & 36,8370 & 152,0807 & 3,5166 \\
\hline 1 & 142,6236 & 113,5846 & 100,4277 & 161,6846 & 33,1045 & 106,6168 & 3,0583 \\
\hline 2 & 157,5593 & 222,3721 & 138,6120 & 161,6846 & 32,8155 & 176,6903 & 4,2266 \\
\hline$\ldots$ & $\ldots$ & $\ldots$ & $\ldots$ & $\ldots$ & $\ldots$ & $\ldots$ & $\ldots$ \\
\hline 5 & 155,4948 & 113,5846 & 103,4990 & 161,6846 & 32,8614 & 132,7849 & 3,2974 \\
\hline 6 & 155,4948 & 113,5846 & 103,4990 & 161,6846 & 32,6026 & 106,6168 & 3,1217 \\
\hline 7 & 155,4948 & 113,5846 & 103,4990 & 161,6846 & 32,5632 & 128,3795 & 3,2645 \\
\hline $\begin{array}{c}\text { (Kim } \text { et } \\
\text { al. } 2001)\end{array}$ & $\mathrm{W} 12 \times 87$ & $\mathrm{~W} 12 \times 87$ & $\mathrm{~W} 10 \times 60$ & $\mathrm{~W} 12 \times 120$ & $\mathrm{~W} 12 \times 26$ & $\mathrm{~W} 12 \times 53$ & \\
\hline & 165,1 & 165,1 & 114,1 & 227,7 & 49,41 & 100,5 & 3,7625 \\
\hline
\end{tabular}

Optimizavimo iteracijų procesui parinktos pradinės elementų skerspjūvių plotų reikšmès yra $5 \%$ didesnès už skerspjūvių plotų reikšmes, gautas konstrukcijai pasiekus plastini suirimą. Skerspjūvių plotų reikšmės yra pateiktos 3.3 lentelès eilutèje pažymètoje ,0“. Pasirinkus šias skerspjūvių plotų reikšmes, kaip pradinị iteracinio skaičiavimo tašką, ir išsprendus siūlomo optimizavimo uždavinio sprendimo algoritmo dvi pirmąsias pakopas, gauname pradines ribojamų poslinkių reikšmes, tenkinančias būtinąsias sąlygas (3.9):

$$
\begin{aligned}
& 14,3008 \mathrm{~cm}<u_{A, x}^{p r .}=22,9039 \mathrm{~cm}<23,0665 \mathrm{~cm}, \\
& -3,8701 \mathrm{~cm}<u_{B, y}^{p r .}=-6,2127 \mathrm{~cm}<-6,8601 \mathrm{~cm} .
\end{aligned}
$$

Atlikus nagrinėjamo rèmo iteracini skaičiavimą, pasirinkto $5 \%$ optimalumo kriterijaus tikslumo optimalus projektas buvo gautas po 7 iteracijų. Projektuojamu parametrų kitimo dinamika optimizavimo iteracinio proceso metu yra pateikta 3.3 lentelèje. Gautas optimalus rẻmo projektas yra užrašytas 7 numeriu pažymėtoje lentelès eilutèje.

Išanalizavus gautus rezultatus, galima teigti, kad pasirinktos ribinès poslinkių reikšmès turi įtaką optimizavimo procesui, nes esant optimaliam projektui šios reikšmės yra ribinès arba artimos joms. Poslinkis $u_{A, x}=13,8669 \mathrm{~cm}$, o tai yra mažiau už pasirinktą ribinę reikšmę $19 \mathrm{~cm}$; poslinkis $u_{B, y}=-4,2459 \mathrm{~cm}$ yra didesnis už pasirinktą ribinę reikšmę $-5,5 \mathrm{~cm}$.

Kim et al. (2001) darbe buvo atlikta 3.5 paveiksle pateikto rèmo analizè. Šiame darbe rèmas buvo modeliuojamas iš standartinių W tipo dvitèju profiliuočių, kurių pasiskirstymas yra pateiktas 3.3 lentelès paskutinèse dvejose eilutėse. Rèmo fiziniai parametrai Kim et al. (2001) darbe pasirinkti tokie patys kaip ir aukščiau aprašytieji optimizavimo uždaviniui spręsti. 


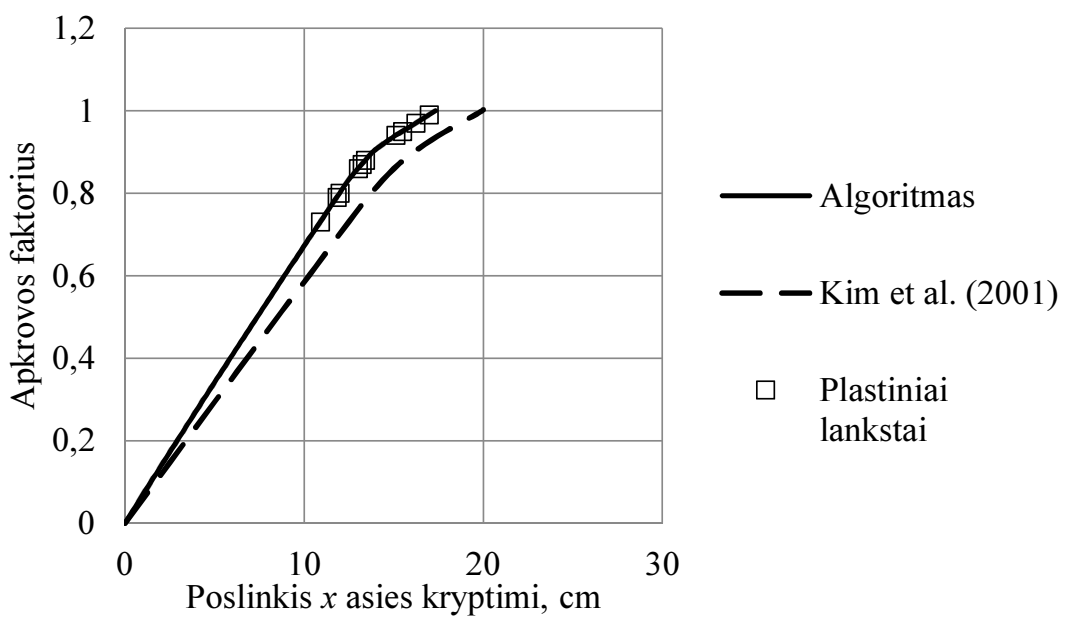

3.7 pav. C taško poslinkio priklausomybė nuo apkrovos redukcijos faktoriaus

Fig. 3.7. C point horizontal displacement's dependence on load reduction coefficient value

Siekiant palyginti gautus rèmų analizès rezultatus su Kim et al. (2001) darbe gautais rezultatais, buvo sudaryti mazgo „C“ (3.7 pav.) horizontalaus poslinkio teigiamos $x$ ašies kryptimi priklausomybių nuo apkrovos redukcijos faktoriaus grafikai, kurie pateikti 3.7 paveiksle. Optimalaus projekto, gauto pagal pasiūlytą algoritmą, konstrukcijos "C“ mazgo poslinkio reikšmè apkrovos faktoriui pasiekus maksimalų dydi yra lygi $17,33 \mathrm{~cm}$, o tai yra $13,35 \%$ mažiau, nei Kim et al. (2001) darbe gauta $20 \mathrm{~cm}$ reikšmè. Pažymètina, kad toks mazgo „C“ poslinkio rezultatas yra gautas optimalios konstrukcijos medžiagos tūriui $\left(3,2645 \mathrm{~m}^{3}\right)$ esant $13,23 \%$ mažesniam nei Kim et al. (2001) darbe $\left(3,7625 \mathrm{~m}^{3}\right)$.

Optimalios konstrukcijos analizè taipogi leido nustatyti plastinių lankstų susidarymo vietas, kurios pavaizduotos 3.6 paveiksle bei eiliškumą didinant apkrovos faktorių (3.4 lentelè). Pažymètina, kad eilinio plastinio lanksto susidarymas konstrukcijos elementuose itakoja poslinkius didinant apkrovos faktorių, apie tai galima spręsti iš 3.7 paveiksle pateiktos diagramos.

3.4 lentelè. Plastinių lankstų susidarymo eiliškumas esant optimaliam rèmo projektui

Table 3.4. The sequence of the plastic hinge occurrence for structure's optimal project

\begin{tabular}{|c|c|c|c|c|c|c|c|c|c|c|}
\hline Eiliškumas & 1 & 2 & 3 & 4 & 5 & 6 & 7 & 8 & 9 & 10 \\
\hline $\begin{array}{c}\text { Apkrovos } \\
\text { faktorius }\end{array}$ & 0,73 & 0,79 & 0,80 & 0,86 & 0,87 & 0,88 & 0,94 & 0,95 & 0,97 & 0,99 \\
\hline
\end{tabular}




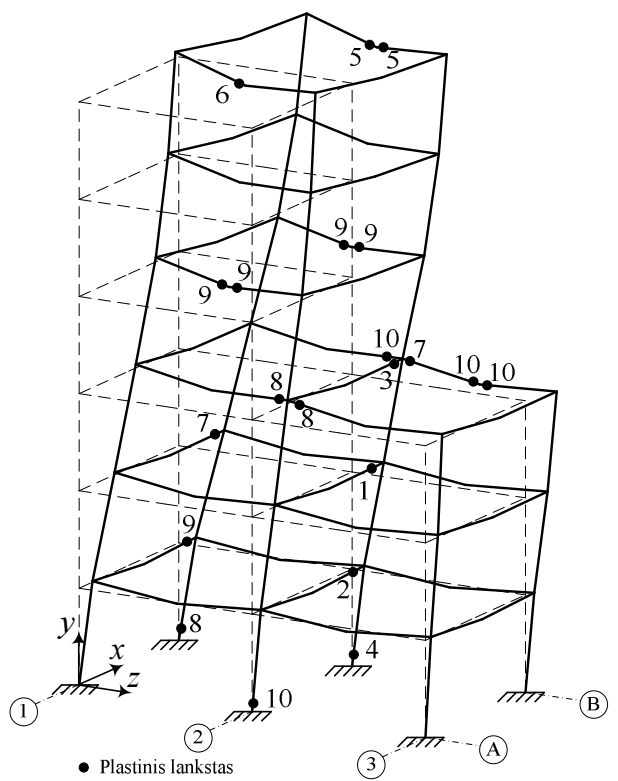

3.6 pav. Šešių aukštų erdvinio rèmo optimalaus projekto deformavimosi bei plastinių lankstų susidarymo vietų schema

Fig. 3.6. The six-story three-dimensional frame deformations and plastic hinge occurrence places schema

Pasirinktos konstrukcijos optimizavimo uždavinio ribojant poslinkius sprendimas bei paruošiamieji skaičiavimai buvo atlikti pritaikius kompiuterinio matematinio skaičiavimo komplekso MATLAB optimizavimo uždavinių skaičiavimu paprogramę Optimization Toolbox. Skaitinio eksperimento komandiniu bylu tekstai, sudaryti pagal MATLAB programavimo kalbos dèsningumus, yra pateikti prieduose $\mathrm{D}, \mathrm{E}$ ir F.

\subsection{Trečiojo skyriaus išvados}

1. Suformuluotas konstrukcijų optimizavimo uždavinio ribojant poslinkius matematinis modelis. İrodyta, kad tai yra iškilojo matematinio programavimo optimizavimo uždavinys, turintis globalujji ekstremumą.

2. Panaudojant baigtinių elementų metodą sudarytos poslinkių apribojimų sąlygu analitinès išraiškos.

3. Atlikto skaitinio eksperimento metu gautieji optimalios konstrukcijos poslinkiai neviršija pasirinktų ribinių reikšmių, o viršutinio mazgo poslinkio reikšmé yra 13,35 \% mažesne nei kitų autorių (Kim et al. (2001)) gauta reikšmé. Pažymėtina, kad gautas optimalios konstrukcijos medžiagos tūris yra 13,23 \% mažesnis nei Kim et al. (2001) darbe nagrinejjamos konstrukcijos. 


\section{Bendrosios išvados}

1. Konstrukcijų deformuoto būvio geometriškai netiesinè elgsena bei medžiagų plastinès savybès turi būti ịvertintos norint, kad skaičiavimas atitiktų realias konstrukcijų darbo sąlygas.

2. Matematinio programavimo teorijos ir mechanikos ekstreminių energinių principu junginys yra efektyvus sudarant naujus geometriškai netiesinių tamprių plastinių statybinių strypinių konstrukcijų skaičiavimo ir optimizavimo uždavinių matematinius modelius.

3. Panaudojant sukurto geometriškai netiesinių tamprių plastinių konstrukcijų analizès uždavinio matematini modeli galima tiksliai nustatyti konstrukcijos tikrojo įtempto deformuoto būvio dydžius. Geriausiai šis rezultatas pasiekiamas matematiniame modelyje naudojant Orbison stiprumo (takumo) sąlygas.

4. Panaudojus sudarytą optimizacijos uždavinio sprendimo algoritmą, skaitinio eksperimento metu gauti optimalios konstrukcijos mazgų poslinkiai 13,35 \% mažesni už Kim et al. (2001) darbe pateikiamas reikšmes. Pažymėtina, kad gautas optimalios konstrukcijos medžiagos tūris yra 13,23 \% mažesnis už Kim et al. (2001) darbe nagrinèjamos konstrukcijos. Tai leidžia taupyti medžiagas ir išteklius projektavimo ir gamybos stadijose. 



\section{Literatūra ir šaltiniai}

Aminmansour, A. 2000. A New Approach to Design of Steel Beam-Columns, Engineering Journal 37(2): 41-72.

ANSI/AISC 360-10: Specification for Structural Steel Buildings. 612 p.

Arora, J. S.; Haug, E. J. 1979. Methods of Design Sensitivity Analysis in Structural Optimization, AIAA Journal 17: 970-974.

Asghar Bhatti, M. 2005. Fundamental Finite Element Analysis and Applications: with Mathematica and Matlab Computations. Wiley. 720 p.

Ashley, H. 1982. On Making Things the Best - Aeronautical Uses of Optimization, Journal of Aircraft (19)1: 5-28.

ASTM Standard A6/A6M: Standard Specification for General Requirements for Rolled Structural Steel Bars, Plates, Shapes, and Sheet Piling. ASTM International, West Conshohocken, 2013.

Atkočiūnas, J. 2011. Optimal shakedown design of elastic-plastic structures. Vilnius: Technika, $300 \mathrm{p}$.

Atkočiūnas, J.; Čižas, A. E. 2009. Netampriu konstrukciju mechanika. Vilnius: Technika, $268 \mathrm{p}$.

Atkočiūnas, J.; Karkauskas, R. 2010. Tampriuju plastiniu strypiniu konstrukciju optimizavimas. Vilnius: Technika, $376 \mathrm{p}$. 
Atkočiūnas, J.; Merkevičiūtè, D.; Venskus, A. 2008. Optimal shakedown design of bar systems: Strength, stiff ness and stability constraints, Computers \& structures $86(17-18)$ : 1757-1768.

Atkočiūnas, J.; Nagevičius, J. 2004. Tamprumo teorijos pagrindai. Vilnius: Technika. 528 p.

Aydoğdu, İ.; Saka, M.P. 2012. Ant colony optimization of irregular steel frames including elemental warping effect, Advances in Engineering Software 44 (1): 150-169.

Barauskas, R. 1998. Baigtiniu elementu metodo pagrindai. Kaunas: Technologija. 375 p. Barauskas, R.; Belevičius, R.; Kačianauskas, R. 2004. Baigtiniu elementu metodo pagrindai. Vilnius: Technika. 612 p.

Baušys R. B.; Karkauskas R. P. 1987. Tamprių-plastiškų rėmų optimizacija, esant standumo apribojimams. Lietuvos mechanikos rinkinys 29: 33-43 (rusų k.).

Belytscho, T.; Liu, W. 2000. Nonlinear finite elements for continua and structures. John Wiley \& Sons Ltd. 300 p.

Bofang, Z.; Zhanmei, L. 1981. Optimization of Double-Curvature Arch Dams, Chinese Journal of Hydraulic Engineering 2: 11-21 (kinų kalba).

Brockenbrough, R. L.; Merritt, F. S. 2006. Structural Steel Designer's Handbook: AISC, AASHTO, AISI, ASTM, AREMA, and ASCE-07 Design Standards. The McGraw-Hill. 959 p.

Chapra, S. C. 2006. Applied Numerical Methods with MATLAB for Engineers and Scientists. McGraw-Hill. 608 p.

Chen, H. F.; Liu, Y. H.; Cen, Z. Z.; Xu, B. Y. 1999. On the Solution of Limit Load and Reference Stress of 3-D Structures under Multi-Loading Systems, Engineering Structures 21: 530-537.

Chiorean C. G.; Barsan G. M. 2005. Large deflection distributed plasticity analysis of 3D steel frameworks, Computers and Structures 83: 1555-1571.

Čyras, A. 1983. Mathematical models for the analysis and optimization of elastoplastic structures. Ellis Horwood Limited, $121 \mathrm{p}$.

Čyras, A.; Borkowski, A.; Karkauskas, R. 2004. Theory and methods of optimization of rigid-plastic systems. Vilnius: Technika, 354 p.

Dantzig, G. B. 1949. Programming in a linear structure, Econometrica 17: 73-74.

Doğan, E.; Saka, M.P. 2012. Optimum design of unbraced steel frames to LRFD-AISC using particle swarm optimization, Advances in Engineering Software 46 (1): 27-34.

Eurocode 3: Design of Steel Structures. Part 1-1: General Rules and Rules for Buildings. Brussels, 2006.

Ferreira, A. J. M. 2009. MATLAB Codes for Finite Element Analysis. Springer. 236 p.

Fiacco, A. V.; McCormick, G. P. 1968. Nonlinear programming: sequential unconstrained minimization techniques. John Wiley and Sons, 210 p. 
Fleury, C.; Sanders, G. 1977. Relations Between Optimality Criteria and Mathematical Programming in Structural Optimization, in Proceedings of the Symposium on Applications of Computer Methods in Engineering, 507-520.

Fox, R. L. 1965. Constraint Surface Normals for Structural Synthesis Techniques, AIAA Journal 3(8): 1517-1518.

Gabriel, G. A.; Ragsdell, K. M. 1977. The generalized reduced gradient method: a reliable tool for optimal design, ASME Journal of Engineering for Industry 99 (2): 394-400.

Gallatly, R. A.; Berke, L.; Gibson, W. 1971. The Use of Optimality Criteria in Automated Structural Design, presented at the 3rd Conference on Matrix Methods in Structural Mechanics.

Hager, W.W.; Hearn, D. W.; Pardalos, P. M. 1994. Large Scale Optimization: State of the Art. Kluwer Academic Publishers, 462 p.

Hajela, G. 1990. Genetic Search - An Approach to the Nonconvex Optimization Problem, AIAA Journal 26(7): 1205-1210.

Hasançebi, O.; Kazemzadeh Azad, S. 2012. An exponential big bang-big crunch algorithm for discrete design optimization of steel frames, Computers \& Structures 110-111: 167179.

Haug, E. J.; Choi, K. K.; Komkov, V. 1986. Design Sensitivity Analysis of Structural Systems. Academic press, 381 p.

Hayalioglu, M. S. 2000. Optimum design of geometrically nonlinear elastic-plastic steel frames via genetic algorithm, Computers \& Structures 77: 527-538.

Heyman, J. 1956. Plastic Design of Beams and Frames for Minimum Material Consumption, Quarterly of Applied Mathematics 8: 373-381.

Kalanta, S. 2007. Taikomosios optimizacijos pagrindai. Vilnius: Technika, 480 p.

Kalanta, S. 1997. New formulations of optimization problems of elasto-plastic bar structures under displacements constraints, Mechanika 4(11): 11-16.

Karkauskas, R. 1997. Analysis of non-holonomic behaviour of geometrically nonlinear elastic-plastic framed structures, Mechanika 4(11): 24-30.

Karkauskas, R. 1998. Tampriai plastinių geometriškai netiesinių strypinių konstrukcijų analizè, Statyba [Civil Engineering] 4(4): 36-42.

Karkauskas, R. 2004. Optimization of Elastic-Plastic Geometrically Nonlinear LightWeight Structures under Stiff ness and Stability Constraints, Journal of Civil Engineering and Management 10(2): 97-106.

Karkauskas, R.; Krutinis, A.; Atkočiūnas, J.; Kalanta, S.; Nagevičius, J. 1995. Statybinès mechanikos uždaviniu sprendimas kompiuteriais. Vilnius: Mokslo ir enciklopediju leidykla, 1995. 264 p.

Kaveh, A.; Talatahari S. 2010. An improved ant colony optimization for the design of planar steel frames, Engineering Structures 32: 864-873. 
Kim S.-E.; Kang K.-W. 2002. Large-scale testing of space steel frame subjected to nonproportional loads, International Journal of Solids and Structures 39: 6411-6427.

Kim S.-E.; Kang K.-W., Lee D.-H. 2003. Full-scale testing of space steel frame subjected to proportional loads, Engineering Structures 25: 69-79.

Kim, I. Y.; Kwak, B. M. 2002. Design space optimization using a numerical design continuation method, International journal for numerical methods in engineering 53: 1979-2002.

Kim S.-E.; Lee D.-H. 2002. Second-order distributed plasticity analysis of space steel frames, Engineering Structures 24: 735-744.

Kim, S.-E.; Park, M.-H.; Choi, S.-H. 2001. Direct design of three-dimensional frames using practical advanced analysis, Engineering Structures 23(11): 1491-1502.

Kelley, J. E. 1960. The cutting plane method for solving convex programs, Journal of SIAM, 8: 702-712.

Klein, B. 1955. Direct use of extremal principles in solving certain optimization problems involving inequalities, Journal of the operations research society of america 3: 168-175. Kwon, Y. W.; Bang, H. 2000. The Finite Element Method Using MATLAB. CRC Press. $624 \mathrm{p}$.

Levy, M. 1874. La statique graphique et ses applications aux constructions. Paris: Gauthier-Villars. 323 p.

Li, G.-Q.; Li, J.-J. 2007. Advanced analysis and design of steel frames. John Wiley \& Sons Inc. $384 \mathrm{p}$.

Myers, R. H.; Montgomery, D. C.; Anderson-Cook, C. M. 2009. Response Surface Methodology: Process and Product Optimization Using Designed Experiments. John Wiley \& Sons, $704 \mathrm{p}$.

MathWorks Inc. 2012. MATLAB ver. 7.14.0.739 (R2012a) software documentation.

Merkevičiūtè, D.; Atkočiūnas, J. 2003. Incremental Method for Unloading Phenomenon Fixation at Shakedown, Journal of Civil Engineering and Management 9(3): 178-191.

Michell, A. G. M. 1904. The Limits of Economy of Material in Frame Structures, Philosophical Magazine 8 (47): 589-597.

Nemhauser, G. L.; Wolsey, L. A. 1988. Integer and Combinatorial Optimization. John Wiley \& Sons, $763 \mathrm{p}$.

Palm, W. J. III. 2010. Introduction to MATLAB for engineers. McGraw-Hill. 704 p.

Polyanin, A. D.; Manzhirov, A. V. 2007. Handbook of Mathematics for Engineers and Scientists. Chapman \& Hall/CRC Press, 1543 p.

Prager, W.; Taylor, J. E. 1968. Problems in Optimal Structural Design, Journal of Applied Mechanics 35(1): 102-106.

Quarteroni, A.; Saleri, F.; Gervasio, P. 2010. Scientific Computing with MATLAB and Octave. Springer. $366 \mathrm{p}$. 
Rajan, S. D.; Nguyen, D. T. 2004. Design optimization of discrete structural systems using MPI-enabled genetic algorithm, Structural and Multidisciplinary Optimization 27 (1-9): 340-348.

Rao, S. S. 2009. Engineering optimization: theory and practice. John Wiley \& Sons, Inc. $840 \mathrm{p}$.

Reddy, J. N. 2004. An Introduction to Nonlinear Finite Element Analysis. Oxford University Press. 488 p.

Reddy, J. N. 2005. An Introduction to the Finite Element Method. McGraw-Hill. 776 p.

Rockafellar, R. T.; 1973. The multiplier method of hestines and powell applied to convex programming, Journal of optimization theory and applications 12(6): 555-562.

Saka M. P.; Hayalioglu, M. S. 1991. Optimum design of geometrically nonlinear elasticplastic steel frames. Computers \& structures 38(3): 329-344.

Saka, M.; Kameshki, E. 1998. Optimum design of unbraced rigid frames, Computers \& Structures 69: 433-442.

Saouma, V. E. 2000. Finite element I. Framed structures. Lecture notes. Dept. of Civil Environmental and Architectural Engineering. University of Colorado. 306 p.

Sarma, K. C.; Adeli, H. 2000. Fuzzy genetic algorithm for optimization of steel structures, Journal of Structural Engineering 126: 596-604.

Schmit, L. A. 1960. Structural design by systematic synthesis, Proceedings of the 2nd ASCE conference on electronic computation, 105-122.

Schmit, L. A.; Farshi, B. 1974. Some Approximation Concepts for Structural Synthesis, AIAA Journal 12(5): 692-699.

Schmit, L. A.; Miura, H. 1976. Approximation Concepts for Efficient Structural Synthesis Vol. 2552. NASA, 289 p.

Schmit, L. A. 1981. Structural Synthesis - Its Genesis and Development, AIAA Journal 19(10): 1249-1263.

Schoofs A. J. G. 1993. Structural optimization history and state-of-the-art, Topics in applied mechanics: Integration of theory and applications in applied mechanics: 339345.

Shanley, F. R. 1952 Weight-Strength Analysis of Aircraft Structures. McGraw-Hill, 394 p.

Smith, I. M.; Griffiths, D. V. 2004. Programming the Finite Element Method. John Wiley \& Sons Inc. 646 p.

Soh, C. K.; Chan, T. K. 2001. Numerical Method for Lower-Bound Solution of the RigidPlastic Limit Analysis Problem, Journal of Engineering Mechanics 127(11): 1075-1081. STR 2.05.08:2005: Plieniniu Konstrukcijų Projektavimas. Pagrindinès Nuostatos. Vilnius, 2005.

Trahair, N.S.; Bradford, M.A.; Nethercot, D.A.; Gardner, L. 2008. The behavior and design of steel structures of EC3. Taylor\&Francis. 490 p. 
Vanderplaats, G. N. 1979. An Efficient Algorithm for Numerical Airfoil Optimization, AIAA Journal of Aircraft 16(12): 842-847.

Vanderplaats, G. N. 1982. Structural Optimization - Past, Present and Future, AIAA Journal 20(7): 992-1000.

Vanderplaats, G. N. 1999. Structural Design Optimization Status and Direction, Journal of Aircraft, 36 (1): 11-20.

Vanderplaats, G. N. 2004. Very Large Scale Continuous and Discrete Variable Optimization, in Proceedings of 10th AIAA/ISSMO Multidisciplinary Analysis and Optimization Conference, Paper No. AIAA-2004-4458.

Vanderplaats, G. N. 2006. Structural optimization for statics, dynamics and beyond, Journal of the Brazilian Society of Mechanical Sciences and Engineering 28 (3): 316322.

Vanderplaats, G. N.; Salajegheh, E. 1989. A New Approximation Method for Stress Constraints in Structural Synthesis, AIAA Journal 27(3): 352-358.

Venkayya, V. B. 1971. Design of Optimum Structures, Computers and Structures Journal 1: 265-309.

Venter, G.; Sobieszczanski-Sobieski, J. 2003. Particle Swarm Optimization, AIAA Journal 41(8): 1583-1589.

Wong, B. 2009. Plastic Analysis and Design of Steel Structures. Elsevier. 256 p.

Wriggers, P. 2008. Nonlinear Finite Element Methods. Springer. 560 p.

Zhang, Y. G.; Lu, M. W. 1995. An Algorithm for Plastic Limit Analysis, Computer Methods in Applied Mechanics and Engineering 126 (3-4): 333-341.

Zienkiewicz, O.; Taylor, R. 2005. The finite element method: its basis and fundamentals. Butterworth-Heinemann. $752 \mathrm{p}$.

Zoutendijk, G. 1960. Methods offeasible directions. Elsevier, 126 p.

Амосов А. А.; Дубинский Ю.А.; Копченова Н.В. 2008. Вычислительные методы для инженеров. Москва: Издательский дом МЭИ, 672 с.

Аткочюнас, Ю. Ю. 1994. Расчет упругопластических систем при повторных напряжениях. Вильнюс: Издательство науки и энциклопедий, 148 р.

Икрин, В. А. 2005. Сопротивление материалов с элементами теории упругости и пластичности. Москва: Издательство АСВ. 424 с.

Каркаускас, Р.; Крутинис, А.; Аткочюнас, Ю. Ю.; Каланта, С.; Нагявичюс, Ю. 1990. Строительная механика программы и решения задач на ЭВМ. Москва: Стройиздат, $359 \mathrm{p}$.

Никитин, С. К.; Чибиряков, В. К. 1987. Решение некоторых задач механики сплошных сред методом инвариантного погружения, Прикладная механика 23: 1723. 
Пермяков, В. А.; Перельмутер, А. В.; Юрченко, В. В. 2008. Оптимальное проектирование стальных стержневых конструкиий. Киев: ТОВ «Издательство «Сталь». 538 с.

Рейтман, М. И.; Ярин, Л. И. 1974. Оптимизация параметров железобетонных конструкций на ЭЦВМ. Москва: Стройиздат. 96 с.

Секулович, М. 1993. Метод конечных элементов. Москва: Стройиздат. 664 с. 



\section{Autoriaus mokslinių publikacijụ disertacijos tema sąrašas}

\section{Straipsniai recenzuojamuose mokslo žurnaluose}

Karkauskas, R.; Popov, M. 2011. The Analysis of geometrically nonlinear elastic-plastic space frames, Journal of Civil Engineering and Management. Vol. 17 (4): 558-568. ISSN 1392-3730. (Thomson ISI Web of Science).

Popov, M.; Karkauskas, R.; Rimkus, L. 2013. The algorithm for nonlinear inelastic optimization of 3D steel frameworks under serviceability requirements, International Journal for Computational Civil and Structural Engineering. Vol. 9 (3): 62-71. ISSN 1524-5845. (Index Copernicus).

Karkauskas, R.; Popov, M. 2009 a. Geometriškai netiesinių rèminių konstrukcijų 2D elemento tangentinès standumo matricos sudarymo ypatumai. Mokslas - Lietuvos ateitis: Statyba Vol. 1 (5): 45-49. ISSN 2029-2341. (Index Copernicus).

Karkauskas, R.; Popov, M. 2009 b. Netamprių geometriškai netiesinių plieninių rèminių konstrukcijų skerspjūvių optimizavimo algoritmas, Statybinès konstrukcijos ir technologijos. Vol. 1 (1): 10-22. ISSN 2029-2317. (Index Copernicus).

\section{Straipsniai kituose leidiniuose}

Каркаускас, Р.; Попов, М. 2007. Алгоритм оптимизации неупругих шарнирностержневых систем и его интеграция с современными компьютерными технологиями анализа конструкций, Проблемы современного бетона $u$ железобетона: сборник трудов: [доклады Международного симпозиума, 16-19 
октября 2007 г., г. Минск] / Министерство архитектуры и строительства Республики Беларусь, Наџиональная академия наук Республики Беларусь, Союз строителей Беларуси, Научно-исследовательское республиканское унитарное предприятие по строительству "Институт БелНИИС". Ч. 1. Бетонные и железобетонные конструкиии. Минск: НП ООО "Стринко": 214-225. ISBN 978985-6476-44-3.

Popov, M.; Karkauskas, R.; Nagevičius, J. 2010. Optimization of 3D steel frames prior to plastic collapse, 10th International Conference Modern Building Materials, Structures and Techniques: selected papers. Vol. 2: 1014-1021. ISBN 9789955285946.

Popov, M.; Karkauskas, R. 2007. Apie tamprių-plastinių plokščių optimizacijos uždavinių integraciją su kompiuterinemis konstrukcijų analizès sistemomis, Statyba: 10-osios Lietuvos jaunuju mokslininku konferencijos "Mokslas - Lietuvos ateitis", ivykusios Vilniuje 2007 m. kovo 29-30 d., pranešimu rinkinys: 193-200. ISBN 978-9955-28-163-4. 


\section{Summary in English}

\section{Introduction}

\section{Problem formulation}

For optimal design of structures, different requirements for design codes, including safety, serviceability and design, must be considered. Structure optimization is the creation of an object that satisfies the prescribed constraints of design and meets the best value of the accepted performance criterion. Structure optimization is the first stage of optimal structural design that allows taking into consideration the above-mentioned requirements and fully describes the behavior of designing a structure. Many questions can be answered by solving different problems of structure optimization: limit to the load value of the structure, the distribution of real stress and a displacement under an applied load, the geometrical parameters of the cross-sections of the elements providing the save and durable behavior of the structure, etc.

Modern tendencies for structural design are connected with the economy of the employed building materials in order to more efficiently use them. Besides traditional calculation based on the linear theory assumptions, more and more design codes define certain aspects of the behavior of nonlinear structures, i.e. strive for investigating the real behavior of the structure. It can be provided by having comprehensive information about the behavior of the building structure under all working conditions at any period of its existence. Naturally, the optimization problem in such a broad concept cannot be solved by the linear theory methods of structural mechanics. The form and size of the structure considerably vary under certain loads, and the principle of a small displacement becomes 
unreliable. In addition, Hook's law is not satisfied and should be substituted by nonlinear relation for a number of materials starting from a certain condition of stresses. Thus, it is necessary to renounce the linear theory assumptions and rely on broader and more complex generalizations of the nonlinear theory:

1. To renounce calculation according to the unstrained condition that tolerates a small displacement.

2. To assess the influence of variations in the geometry of the structure on its stressstrain state (SSS).

3. To maintain non-linear stress-strain relationship and evaluate occurring plastic deformations taking into account that the structures of certain materials obtain very large displacements before plastic collapse, and therefore might not satisfy requirements for regular service.

4. To select yield conditions for structural elements so that to more precisely define the behavior of structures. Design codes of different countries present linearized yield conditions, which significantly restricts the behavior of structures. Thus, the necessity to refer to yield conditions having a relatively wider yield value and presented in the works of other authors arises.

5. To carefully consider the real displacement of the structure for recording conditions for the displacement constraints of the optimization problem.

Having considered all above introduced aspects, a mathematical model has been created finding a direct solution to which is a rather serious problem. The thesis suggests an original solution algorithm that allows avoiding difficulties that arise working towards the clarification and having stricter control over the process of dealing with the optimization problem.

\section{Relevance of the thesis}

In the thesis created new mathematical models for geometrically nonlinear elastic plastic construction structures calculation and optimization under displacements constraints by using mathematical programming theory an mechanical principle of extreme energy. The original algorithm using modern computer technologies for geometrically nonlinear elastic plastic frameworks structures under displacements constraints is created. It opens new possibilities in construction engineering for in economy of material and resources in the stages of project and production.

\section{Research object}

The thesis examines the creation of mathematical models for optimization problems of inelastic geometrically nonlinear frame structures and focuses on the possibilities of working out solutions.

\section{The goal of the thesis}

The goal of the thesis is to develop an original algorithm for finding a solution to the mathematical model of an optimization problem of geometrically nonlinear elastic-plastic three-dimensional frame structures. The introduced model considers all above-mentioned aspects. The created algorithm allows monitoring the deformability of the structure within the iteration process and guarantees a successful convergence of the problem. 


\section{Tasks of the thesis}

To reach the aim of the work, the following problems must be considered:

1. To develop a technique for composing a tangent stiffness matrix of the threedimensional finite element and to promote a symbolic calculation program to obtain the expression of this matrix.

2. To create a mathematical model for the optimization problem of the geometrically nonlinear elastic-plastic three-dimensional frame structure and solve this problem. To make comparative analysis of obtained solution results with those received by other authors.

3. To create a mathematical model for the optimization problem of the geometrically nonlinear elastic-plastic three-dimensional frame structure under displacement constraints and to obtain this problem numerical solution result. To make comparative analysis of obtained solution results.

4. To combine the problems of second-order elastic calculation, analysis of an elastic-plastic structure and optimization under displacement constraints into a single general algorithm for an iterative solution.

5. To check the efficiency of the suggested algorithm for finding a solution to the optimization problem applying software created using simulation techniques.

\section{Research methods}

The thesis applies to numerical simulation methods, including the finite element method, the Newton-Raphson method for solving nonlinear equations and the methods for solving nonlinear optimization problems.

\section{Scientific novelty}

The principles of the suggested original algorithm for proposing a solution to the structural optimization problem can be applied calculating any type of the structure.

The methodology for a tangent stiffness matrix of the three-dimensional finite element has been extended and can be applied establishing the expressions of tangent stiffness matrices of other types of finite elements. The principles of the employed methodology can be used for creating symbolic calculation programs to obtain the expressions of tangent matrices of other types of finite elements.

A mathematical model for the analysis problem of geometrically nonlinear elasticplastic three-dimensional frame structures under nonlinear yield conditions has been formulated and solved, which allows establishing the real SSS close to the behavior of the real structure taking into account the investigated structure.

The optimization problem of structures has been formulated and solved using nonlinear conditions for yield and displacement constraints and considering the real SSS of structures.

\section{Practical significance of dissertation}

The suggested algorithm for the mathematical model of the optimization problem of geometrically nonlinear elastic-plastic three-dimensional steel frame structures cover safety, serviceability and design requirements and can be applied for designing or reconstructing real structures and launching an optimal project of the structure. 


\section{Defended statements}

1. Material plastic properties and geometrically nonlinear behavior of structures that proper for many (especially steel) structures should be considering in construction structures calculations to approach it to real materials and work condition.

2. The mathematical programming theory and mechanical principle of extreme energy make possible to create new mathematical models for geometrically nonlinear elastic plastic construction structures optimization problems under displacements constraints and algorithms and methods for these problems solution.

3. The improvement of elastic plastic geometrically nonlinear structures optimization models is theoretical and practical foundation for construction structures economical and scientific development: the new possibilities of material and resources saving at projecting and production stages.

\section{Structure of thesis}

The work consist of introduction, three chapters, conclusions, references, list of publications and annexes. The total work content is 118 pages, 32 figures, 12 tables and 8 annexes.

\section{The structure optimization under complex constraints}

The task for the optimization problem of the frames examined in the thesis is formulated as follows: knowing the configuration of the frame and external forces, the distribution of the cross-sectional areas $A_{k}$ of structural elements must be found; distribution must satisfy the optimal criterion for a minimum volume structure when individual structural elements are exposed to plastic deformations. Serviceability requirements for the considered optimization problem should include, first of all, conditions defining the real SSS of the structure. Such conditions are dependencies of the generalized Lagrange problem. Second, stiffness conditions should include displacement boundaries in certain nodes of the structure with reference to indicated directions: $\mathbf{u}_{t}^{-} \leq \mathbf{u}_{e, t}+\mathbf{u}_{r, t} \leq \mathbf{u}_{t}^{+}$, where $\mathbf{u}_{t}^{-}$and $\mathbf{u}_{t}^{+}$ are prescribed lower and upper displacement bounds in $t$ direction. Apart from the above introduced conditions, different technological or structural limitations to element stability or a lower reference limit to internal forces $\mathbf{S}_{0}^{\min }$ can be applied. Such a situation restrict the free movement of non-elastic strains of the structure, and therefore the elements of the structure having optimal cross-sections face elastic and plastic deformations affected by residual internal forces $\mathbf{S}_{r}$ and residual displacements $\mathbf{u}_{r}$. If any of the abovementioned boundaries become active, the structure does not reach plastic collapse.

Therefore, the mathematical model of the formulated optimization problem is as follows (Čyras et al. (2004), Karkauskas (2004)): 
Find $\quad V\left(A_{k}\right) \rightarrow \min$,

when

$$
\begin{aligned}
& \mathbf{f}\left(\mathbf{S}_{e}, \mathbf{S}_{r}, \mathbf{S}_{0}\left(A_{k}\right)\right) \leq \mathbf{1}, \mathbf{A}_{n} \mathbf{S}_{r}=\mathbf{F}-\mathbf{A}_{n} \mathbf{S}_{e}, \\
& \mathbf{D}_{n} \boldsymbol{S}_{r}-\mathbf{A}_{n}{ }^{T} \boldsymbol{u}_{r}+\left[\nabla^{T} \mathbf{f}\left(\mathbf{S}_{e}, \mathbf{S}_{r}, \mathbf{S}_{0}\left(A_{k}\right)\right)\right] \boldsymbol{\lambda}=\mathbf{0}, \\
& \boldsymbol{\lambda}^{T}\left(\mathbf{1}-\mathbf{f}\left(\mathbf{S}_{e}, \mathbf{S}_{r}, \mathbf{S}_{0}\left(A_{k}\right)\right)\right)=\mathbf{0}, \\
& \mathbf{u}_{t}^{-} \leq \mathbf{u}_{e, t}+\mathbf{u}_{r, t} \leq \mathbf{u}_{t}^{+}, \mathbf{S}_{0}\left(A_{k}\right) \geq \mathbf{S}_{0}^{\min }, \boldsymbol{\lambda} \geq \mathbf{0}, k=1,2, \ldots, s .
\end{aligned}
$$

where $A_{k}$ is the cross-sectional area of the $k$ group of structural elements; $\mathbf{S}_{0}$ is the vector of the limit values of internal forces; $\mathbf{D}_{n}$ is the quasi-diagonal flexibility matrix of the finite element structure considering variations in the geometry of the structure; $\mathbf{A}_{n}$ is the matrix of the coefficients of balance equations and related to the displacements of a discrete model; $\mathbf{F}$ is the vector of external forces applied to the nodes of the discrete model of the structure; $\boldsymbol{\lambda}$ is the vector of Lagrange multipliers.

This is a multi-extremal problem of nonlinear mathematical programming. Multiextremality is the result of Kuhn-Tucker conditions, i.e. equations $\lambda^{T}\left(\mathbf{1}-\mathbf{f}\left(\mathbf{S}_{e}, \mathbf{S}_{r}, \mathbf{S}_{0}\left(A_{k}\right)\right)\right)=\mathbf{0}$. The problem is solved in an iterative way, and this factor makes the process of accomplishing task complicated.

To avoid the above mentioned complications, an original algorithm for the nonlinear optimization of structures (implementing iterative procedures in the optimization cycle) is created. The cycle of the optimization problem includes three stages. The overall schematic view of the algorithm for the optimization problem is presented in Fig. S1.

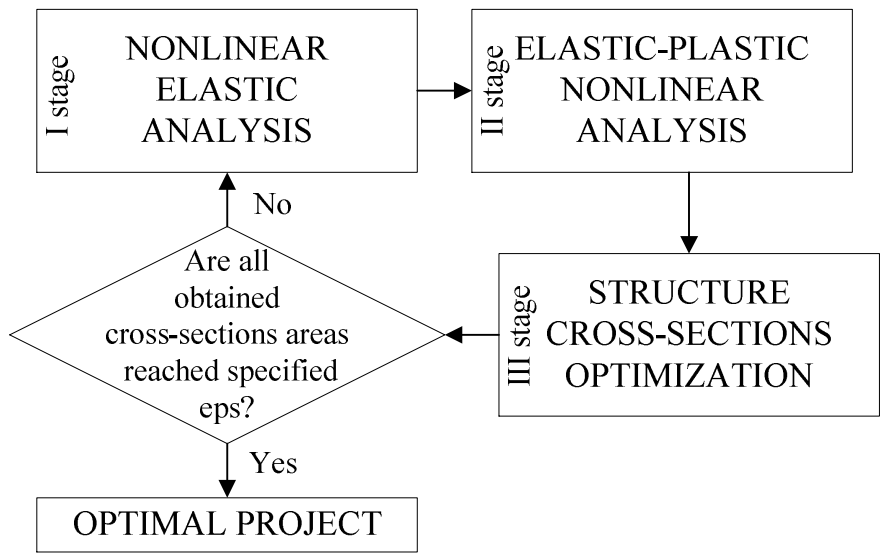

Fig. S1. Solution algorithm of optimization problem (S1.1)

In scientific literature there are not enough paid attention for geometrically nonlinear elastic plastic construction structures under displacements constraints calculation and optimization problematic (there are few theoretical and construction structures experimental development works). In order to this it is necessary to create a mathematical model for the optimization problem of the geometrically nonlinear elastic-plastic three- 
dimensional frame structure under displacement constraints, to solve this problem and to make comparative analysis of obtained solution results.

\section{The analysis of geometrically nonlinear structures}

The nonlinear elastic analysis problem of the structure is the first stage of the suggested (S1.1) algorithm for solving the optimization problem. The problem of the stage is worked out applying the equilibrium equation for the tangent stiffness method of finite elements (Barauskas 1998, Barauskas et al. 2004):

$$
\mathbf{K}_{\tau} \mathbf{u}_{e}=\mathbf{F} .
$$

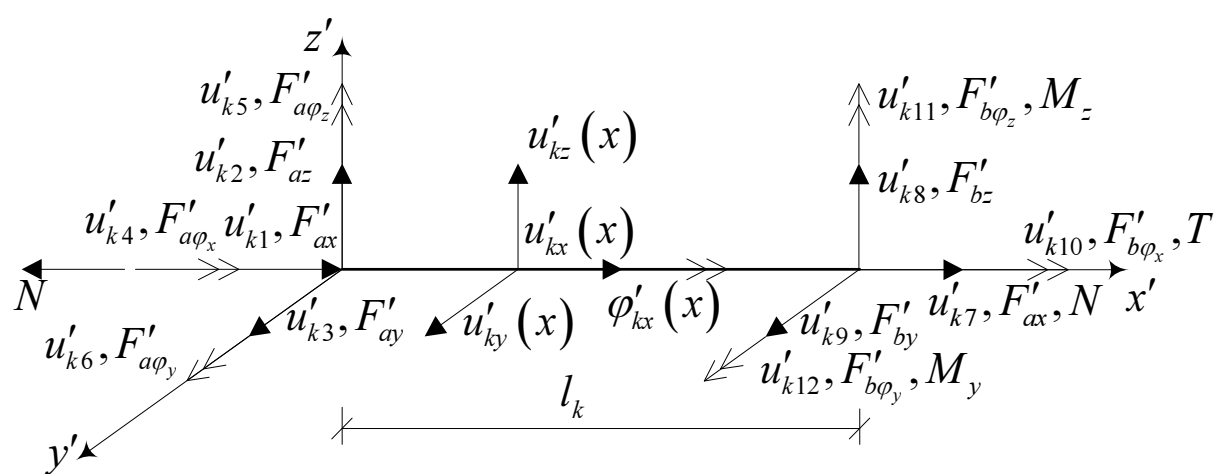

Fig. S2. The space frame finite element

The investigating element of the space frame structure is shown in Fig. S2. It is accepted that the element's nodes can have the displacements which are considerably larger than the element's dimensions, but the own form of the element does not change. Element's strains stay small. The element's internal forces vector in local coordinates system is writing as follows:

$$
\begin{aligned}
\boldsymbol{\Psi}_{k}\left(\mathbf{u}_{k}^{\prime}\right)=\int_{-b / 2}^{b / 2} \int_{-h / 2}^{h / 2} \int_{0}^{l}\left\{\frac{\partial \boldsymbol{\varepsilon}_{k}(x)}{\partial \mathbf{u}_{k}^{\prime}}\right\}^{T} \boldsymbol{\sigma}_{k}(x) d x d y d z+ \\
\int_{-b / 2-h / 2}^{b / 2} \int_{-h}^{h / 2}\left\{\frac{\partial \boldsymbol{\gamma}_{k}(x)}{\partial \mathbf{u}_{k}^{\prime}}\right\}^{T} \boldsymbol{\tau}_{k}(x) d x d y d z .
\end{aligned}
$$

The beam element is under rotation and subjected to compression, tension and bending in two perpendicular axes. The vector of displacements for any point of the frame element:

$$
\mathbf{u}_{k}(x)=\left[\begin{array}{llll}
u_{x}^{\prime}(x) & u_{y}^{\prime}(x) & u_{z}^{\prime}(x) & \varphi_{x}^{\prime}(x)
\end{array}\right]^{T} .
$$


Expressed by the nodal displacements as follows:

$$
\mathbf{u}_{k}(x)=\mathbf{N}_{k}(x) \mathbf{u}_{k}^{\prime},
$$

here $\mathbf{N}_{k}(x)$ is the matrix of the Hermitian polynomials.

The total longitudinal and lateral deformations for the nonlinear space frame element can be obtained in the following way:

$$
\begin{gathered}
\boldsymbol{\varepsilon}_{k}(x)=\Delta_{x}-y \kappa_{y}-z \kappa_{z}= \\
\frac{\partial u_{x}^{\prime}(x)}{\partial x}+\frac{1}{2}\left(\frac{\partial u_{y}^{\prime}(x)}{\partial x}\right)^{2}+\frac{1}{2}\left(\frac{\partial u_{z}^{\prime}(x)}{\partial x}\right)^{2}-y \frac{\partial^{2} u_{z}^{\prime}(x)}{\partial x^{2}}-z \frac{\partial^{2} u_{y}^{\prime}(x)}{\partial x^{2}}, \\
\gamma_{k}(x)=y \theta_{x}+z \theta_{x}=y \frac{\partial \varphi_{x}^{\prime}(x)}{\partial x}+z \frac{\partial \varphi_{x}^{\prime}(x)}{\partial x} .
\end{gathered}
$$

The three-dimensional frame element is received inserting (S2.5) and (S2.6) into the expression of (S2.2) and can be recorded as follows:

$$
\mathbf{k}_{\tau}\left(\mathbf{u}_{k}^{\prime}\right)=\frac{\partial \boldsymbol{\Psi}_{k}\left(\mathbf{u}_{k}^{\prime}\right)}{\partial \mathbf{u}_{k}^{\prime}}=\mathbf{k}_{e}^{\prime}+\mathbf{k}_{g}^{\prime}+\mathbf{k}_{u}^{\prime},
$$

here

$$
\begin{gathered}
\mathbf{k}_{e}^{\prime}=E \int_{-b / 2}^{b / 2} \int_{-h / 2}^{h / 2} \int\left(\mathbf{C}_{0}^{T} \mathbf{C}_{0}-z \mathbf{C}_{0}^{T} \mathbf{C}_{4}(x)-y \mathbf{C}_{0}^{T} \mathbf{C}_{5}(x)-\right. \\
z \mathbf{C}_{4}(x)^{T} \mathbf{C}_{0}+z^{2} \mathbf{C}_{4}(x)^{T} \mathbf{C}_{4}(x)+z y \mathbf{C}_{4}(x)^{T} \mathbf{C}_{5}(x)- \\
\left.y \mathbf{C}_{5}(x)^{T} \mathbf{C}_{0}+z y \mathbf{C}_{5}(x)^{T} \mathbf{C}_{4}(x)+y^{2} \mathbf{C}_{5}(x)^{T} \mathbf{C}_{5}(x)\right) d x d y d z+ \\
G \int_{-b / 2}^{b / 2} \int_{-h / 2}^{h / 2} \int_{0}^{l}\left(z^{2} \mathbf{C}_{3}^{T} \mathbf{C}_{3}-z y \mathbf{C}_{3}^{T} \mathbf{C}_{3}+y^{2} \mathbf{C}_{3}{ }^{T} \mathbf{C}_{3}\right) d x d y d z
\end{gathered}
$$

is element's small displacements matrix;

$$
\mathbf{k}_{g}^{\prime}=\int_{-b / 2}^{b / 2} \int_{-h / 2}^{h / 2} \int_{0}^{l}\left(\mathbf{C}_{6}(x)^{T}+\mathbf{C}_{7}(x)^{T}\right) \boldsymbol{\sigma}_{k}(x) d x d y d z
$$

is geometric stiffness matrix; 


$$
\begin{aligned}
& \mathbf{k}_{u}^{\prime}=E \int_{-b / 2}^{b / 2} \int_{-h / 2}^{h / 2} \int_{0}^{l}\left(0,5 \mathbf{C}_{0}^{T} \mathbf{u}_{k}^{\prime T} \mathbf{C}_{6}(x)+0,5 \mathbf{C}_{0}^{T}{ }_{\mathbf{u}_{k}^{\prime}}^{T} \mathbf{C}_{7}(x)+\right. \\
& \mathbf{C}_{6}(x)^{T} \mathbf{u}_{k}^{\prime} \mathbf{C}_{0}+0,5 \mathbf{C}_{6}(x)^{T} \mathbf{u}_{k}^{\prime} \mathbf{u}_{k}^{\prime} \mathbf{C}_{6}(x)+ \\
& 0,5 \mathbf{C}_{6}(x)^{T} \mathbf{u}_{k}^{\prime} \mathbf{u}_{k}^{\prime T} \mathbf{C}_{7}(x)-z \mathbf{C}_{6}(x)^{T} \mathbf{u}_{k}^{\prime} \mathbf{C}_{9}(x)- \\
& y \mathbf{C}_{6}(x)^{T} \mathbf{u}_{k}^{\prime} \mathbf{C}_{5}(x)+\mathbf{C}_{7}(x)^{T} \mathbf{u}_{k}^{\prime} \mathbf{C}_{0}+ \\
& 0,5 \mathbf{C}_{7}(x)^{T} \mathbf{u}_{k}^{\prime} \mathbf{u}_{k}^{\prime T} \mathbf{C}_{6}(x)+0,5 \mathbf{C}_{7}(x)^{T} \mathbf{u}_{k}^{\prime} \mathbf{u}_{k}^{\prime} \mathbf{C}_{7}(x)- \\
& z \mathbf{C}_{7}(x)^{T} \mathbf{u}_{k}^{\prime} \mathbf{C}_{4}(x)-y \mathbf{C}_{7}(x)^{T} \mathbf{u}_{k}^{\prime} \mathbf{C}_{5}(x)- \\
& 0,5 z \mathbf{C}_{4}(x)^{T} \mathbf{u}_{k}^{\prime T} \mathbf{C}_{6}(x)-0,5 z \mathbf{C}_{4}(x)^{T} \mathbf{u}_{k}^{T} \mathbf{C}_{7}(x)- \\
&\left.0,5 y \mathbf{C}_{5}(x)^{T} \mathbf{u}_{k}^{\prime T} \mathbf{C}_{6}(x)-0,5 y \mathbf{C}_{5}(x)^{T} \mathbf{u}_{k}^{\prime T} \mathbf{C}_{7}(x)\right) d x d y d z
\end{aligned}
$$

is element's initial displacement stiffness matrix.

All matrices of structural stiffness, following the transformation of axes are combined into the stiffness matrix $\mathbf{K}_{\tau}$ of the whole structure.

For numerical realization of the first algorithm's stage tangent stiffness technique Newton-Raphson method with load control is used in order to solve a set of nonlinear equations (S2.1).

The second stage of the suggested algorithm is elastic-plastic nonlinear analysis. The real values of the SSS are obtained as a result of the problem encountered at this stage. This is a sum of the internal forces of nonlinear analysis, including residual internal forces and displacement values.

The principle of extreme energy (Čyras 1983; Čyras et al. 2004) was used for obtaining residual internal forces of the elastic-plastic system in the real mode. This principle is formulated as follows:

„Of all statically admissible vectors of residual forces at the step to be considered, the actual vector is one for which the increment of complementary energy is minimum".

Thus, the above formulated principle of extreme energy corresponds the following problem of nonlinear mathematical programming:

Find

$$
\min U_{r}=\frac{1}{2} \mathbf{S}_{r}^{T} \mathbf{D}_{n} \mathbf{S}_{r},
$$

when

$$
\begin{aligned}
& \mathbf{A}_{n} \mathbf{S}_{r}=\mathbf{F}-\mathbf{A}_{n} \mathbf{S}_{e}, \\
& \mathbf{f}\left(\mathbf{S}_{e}, \mathbf{S}_{r}, \mathbf{S}_{0}\right) \leq \mathbf{1} .
\end{aligned}
$$

The before introduced problem is a variational analysis of a convex mathematical programming problem. This is the minimization of the graduated function over a convex set. Further in the text, (S2.11) will be referred to as the static formulation of the problem analyzing residual internal forces.

The dual problem determining residual displacements of the structure is formulated applying the Lagrange function of problem (S2.11). Lagrange multipliers of equilibrium 
conditions are the vector of residual displacements $\mathbf{u}_{r}$ and yield conditions are represented by the vector of plastic multipliers $\lambda$. Finally, the following dual problem is obtained:

Find

$$
\max -\frac{1}{2} \mathbf{S}_{r}^{T} \mathbf{D}_{n} \mathbf{S}_{r}-\boldsymbol{\lambda}^{T}\left(\mathbf{1}-\mathbf{f}\left(\mathbf{S}_{e}, \mathbf{S}_{r}, \mathbf{S}_{0}\right)\right)+\mathbf{u}_{r}^{T} \mathbf{F}-\mathbf{S}_{r}^{T} \mathbf{D}_{n} \mathbf{S}_{e}-
$$

$$
\lambda^{T}\left[\nabla \mathbf{f}\left(\mathbf{S}_{e}, \mathbf{S}_{r}, \mathbf{S}_{0}\right)\right]\left(\mathbf{S}_{e}+\mathbf{S}_{r}\right)
$$

when

$$
\mathbf{D S}_{r}+\left[\nabla^{T} \mathbf{f}\left(\mathbf{S}_{e}, \mathbf{S}_{r}, \mathbf{S}_{0}\right)\right] \boldsymbol{\lambda}-\mathbf{A}_{n}{ }^{T} \mathbf{u}_{r}=\mathbf{0}, \boldsymbol{\lambda} \geq \mathbf{0}
$$

This is a kinematic formulation of the problem analyzing residual internal forces.

While formulating the problems analyzing elastic-plastic structures and their mathematical models, terms for selecting appropriate strength remains one of the crucial aspects. As for the examination of three-dimensional structures, a complex strain state is worth being mentioned. Also, the application of strength conditions, including tensioncompression strength as well as bending around one or another axis of the structural element should be purposeful. Strength conditions, under a complex stress-strain state, are frequently described in construction codes and specifications regulating the design of building structures (ANSI/AISC 360-10).

According to construction specifications AISC-LRFD (Kim S.-E. et al. 2001; Aminmansour, A. 2000; ANSI/AISC 360-10), the double-axis yield strength surface of the beam-column element (presented graphically in Fig. 3S) is expressed by the equation given below:

$$
\begin{aligned}
& 1 \geq \frac{N_{j}}{N_{y, j}}+\frac{8}{9} \frac{M_{y, j}}{M_{y p, j}}+\frac{8}{9} \frac{M_{z, j}}{M_{z p, j}}, k a i \frac{N_{j}}{N_{y, j}} \geq \frac{2}{9} \frac{M_{y, j}}{M_{y p, j}}+\frac{2}{9} \frac{M_{z, j}}{M_{z p, j}}, \\
& 1 \geq \frac{N_{j}}{2 N_{y, j}}+\frac{M_{y, j}}{M_{y p, j}}+\frac{M_{z, j}}{M_{z p, j}}, k a i \frac{N_{j}}{N_{y, j}}<\frac{2}{9} \frac{M_{y, j}}{M_{y p, j}}+\frac{2}{9} \frac{M_{z, j}}{M_{z p, j}} .
\end{aligned}
$$

Though strength conditions are provided by design codes and specifications, the efforts of various researchers were made to accurately reflect a complex state of strains. An example is Orbison's full yield surface of the cross-section (presented in Kim et al. (2001), Chiorean and Barsan (2005)) described as follows:

$$
1 \geq 1,15 n_{j}^{2}+m_{z, j}^{2}+m_{y, j}^{4}+3,67 n_{j}^{2} m_{z, j}^{2}+3,0 n_{j}^{6} m_{y, j}^{2}+4,65 m_{z, j}^{4} m_{y, j}^{2},
$$

here $n_{j}=N_{j} / N_{y, j} ; m_{y, j}=M_{y, j} / M_{y p_{j} j}$ is , weak axis" of element's cross-section area; $m_{z, j}=M_{z, j} / M_{z p_{j} j}$ is ,strong axis" of element's cross-section area.

Orbison's yield surface is shown in Fig. S3.

The local stability of the structure is checked according to formulas (S2.13) or (S2.14) when compression members are loaded up to the values of their critical forces the internal forces of the compressed elements of which are calculated according to requirements for design standards. Eurocode 32006 normative documents suggest the following expression:

$$
N_{b, R d}=\chi A f_{u} / \gamma_{\mathrm{M} 1}
$$


here $N_{b, R d}$ is the element's design value of buckling strength; $\chi$ is the buckling coefficient; $A$ is structure's element cross-section area; $f_{u}$ is the structure's material strength (yield) limit; $\gamma_{\mathrm{M} 1}$ is the partial coefficient (is taking equal 1,0 ).
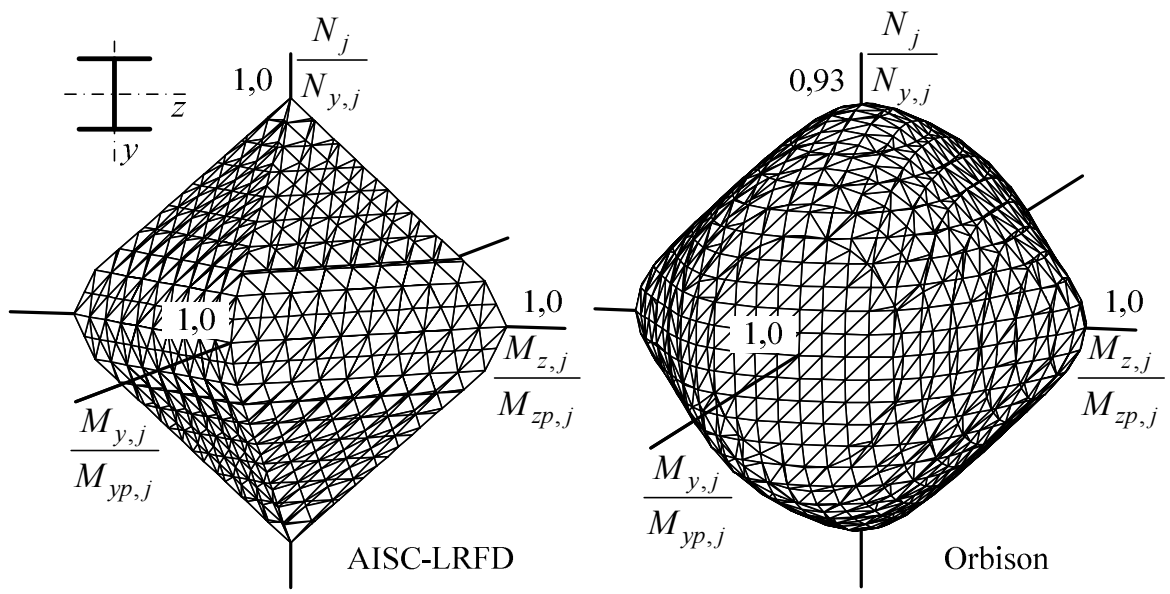

Fig. S3. Yield surfaces

Buckling coefficient $\chi$ is obtained with reference to Eurocode 32006 accordingly to proper conventional slenderness ratio $\bar{\lambda}$ that depends on buckling length $l_{b}$ and effective length coefficient $\mu$ received taking into account STR 2.05.08:2005 requirements.

The global stability of the whole structure is checked by calculating a determinant of the tangential stiffness matrix of the entire structure $\mathbf{K}_{\tau}$ according to equation (S2.1) at the last stage of calculating numerical implementation. If the value of the determinant equals zero, the structure has lost the overall stability. Further calculations are not performed.

All above-mentioned conditions do not take into consideration the effect of torsional strains on the complex state of strains. Consequently, to get comprehensive information about strength, some torsional strength conditions should be used. Torsional strength condition given by Eurocode 3 (2006) is expressed by the equation:

$$
T_{E d} / T_{R d} \leq 1,0,
$$

here $T_{E d}$ is torsion moment applied to the structural element; $T_{R d}$ is torsion strength specified for the structural element.

A two-storied space frame structure (Fig. S4) was chosen for the numerical realization of the above-mentioned mathematical models. This structure was studied by Kim et al. (2003) (testing the full-size model made of real steel profiles was described) and Kim and Lee (2002) (the analysis of a discrete computer-generated model in the environment of program ABAQUS was presented). In the latter research, the obtained results were compared with data obtained in the former research.

Structural elements are modelled using the profiles of type $\mathrm{H} 150 \times 150 \times 7 \times 10$. The overall dimensions of the frame (Fig. S4) are as follows: width in the direction of axis $x$ is $2,5 \mathrm{~m}$, length in the direction of axis $y-3,0 \mathrm{~m}$, height from the column element base to the second floor level $-1,76 \mathrm{~m}$ and height from the second floor level to the roof is $2,2 \mathrm{~m}$. 
The geometrical and physical parameters of the cross-section of any structural element are constant through its full length. The yield strength of all structural elements - $320 \mathrm{MPa}$ while the elastic modulus is $221 \mathrm{GPa}$ and the shear modulus is $85 \mathrm{GPa}$. The model of the structure is subjected to the action of three various types.

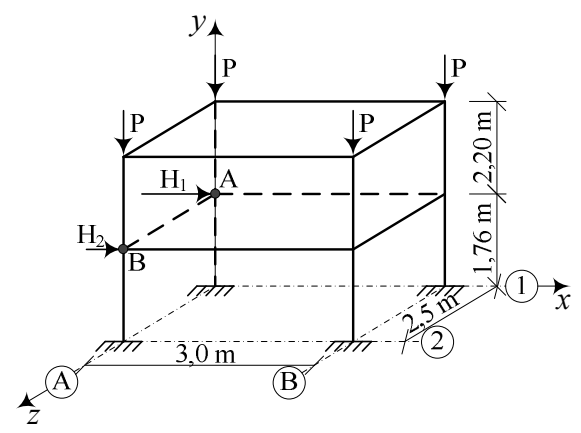

Fig. S4. The two-story space frame discrete model

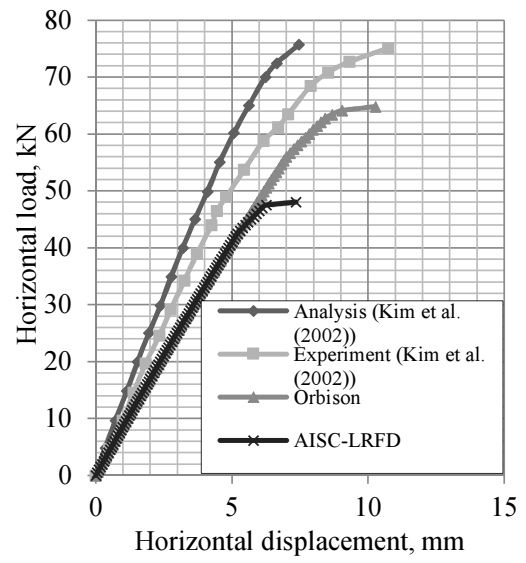

Fig. S5. Node B load-displacement curve under the first load case

Two calculations were performed for every load case. The first calculation was made applying Orbison's strength conditions (S2.14) and the second - AISC-LRFD standard strength conditions (S2.13). The results obtained in the performed two-storied space frame analysis were compared with data presented in work Kim and Lee (2002).

The carried out analysis revealed that under Orbison's strength conditions (S2.14), the results closely approached data obtained by Kim and Lee (2002) (Fig. S5). A greater deviation from the results presented in this work could be observed when strength conditions specified by AISC-LRFD design code (S2.13) were used. These conditions are more strict or conservative than those of Orbison's strength. It can be explained by the fact that AISC-LRFD is the construction code regulating structural steel design. While applying such standards, it is usually assumed that the structure works only within elastic work limits. The characters of load displacement diagrams and its comparison allow making a conclusion that construction work is obtained by the proposed algorithm and agree well with Kim et al. (2003) results.

\section{The problem of structure optimization under displacement constraints}

The general mathematical model of the third stage of the suggested algorithm, which is the problem of structure optimization under displacement constraints, is as follows: 
Find $\min V\left(A_{k}\right)$,

when

$$
\begin{gathered}
\mathbf{f}\left(\mathbf{S}, \mathbf{S}_{0}\left(A_{k}\right)\right) \leq \mathbf{1}, \\
u_{t}^{-} \leq u_{t} \leq u_{t}^{+}, \\
A_{k} \geq A_{k}^{\min }, \\
t=1,2, \ldots, m_{t}, k=1,2, \ldots, s,
\end{gathered}
$$

where $A_{k}^{\min }$ is the lower limit to design requirements.

Optimization problem (S3.1)-(S3.4) is a convex nonlinear mathematical programming problem having only one extremum. This problem is solved having comprehensive information about the real SSS under an applied load, i.e. when a solution to problems (S2.1) and (S2.12) is reached.

For an efficient use of the mathematical model for optimization problem (S3.1)(S3.4) as well as for a good convergence of the obtained results, four important steps of preliminary calculations must be performed.

The first of the above mentioned steps of calculation is selecting the lower limits of the cross-sectional areas of structural constraints $A_{k}^{\min }$ (S3.4). This is achieved through finding an answer to the optimization problem of the structure at the stage of plastic collapse The mathematical model of the problem has the following form:

Find

$$
V\left(A_{k}^{\min }\right) \rightarrow \min ,
$$

when

$$
\mathbf{f}\left(\mathbf{S}_{e}, \mathbf{S}_{r}, \mathbf{S}_{0}\left(A_{k}^{\min }\right)\right) \leq \mathbf{1} \text {, }
$$

$$
\mathbf{A}_{n} \mathbf{S}_{r}=\mathbf{F}-\mathbf{A}_{n} \mathbf{S}_{e}, A_{k}^{\min } \geq \mathbf{0}, k=1,2, \ldots, s .
$$

This problem is solved with reference to the iteration method. The solution algorithm is presented in Fig. S6.

The next important step of calculation is the estimation of displacement boundaries. They can be determined using cross-sectional areas obtained solving problem (S3.5) and changing the applied load ratio. The upper limits of displacements can be established applying a significantly smaller load ratio than that employed for dealing with problem (S3.5) and considering problems (S2.1) and (S2.12), i.e. finding out displacements that occurred in the structure prior to plastic collapse. Further, displacements are calculated when the first plastic hinge occurs in the structure. Displacements result from a decrease in the load ratio and working out problems (S2.1) and (S2.12). The received values are the lower limits of displacement constraints, i.e. displacements corresponding an elastic response. Thus, the chosen values of conditions for displacement constraints of the optimization problem ((S3.1)-(S3.4)) should be between the following limit values:

$$
\text { when } \boldsymbol{u}^{+}>0 \text {, so } \boldsymbol{u}_{\min }^{+} \leq \boldsymbol{u}^{+} \leq \boldsymbol{u}_{\max }^{+} \text {; when } \boldsymbol{u}^{-}<0 \text {, so } \boldsymbol{u}_{\min }^{-} \geq \boldsymbol{u}^{-} \geq \boldsymbol{u}_{\max }^{-} \text {. }
$$

This is the way the elastic-plastic behavior of the structure can be ensured.

The third step of calculation covers the estimation of the start point of problem ((S3.1)-(S3.4)) and takes place changing the values of the areas of element cross-sections 
and solving problems (S2.1) and (S2.12). The obtained values of displacements should be higher than the displacements of an elastic response and lower than displacements when the structure is prior to plastic collapse, i.e. must satisfy the following inequalities, which means displacements must agree with the above mentioned restrictions (S3.6).

The fourth important step of calculation establishes real displacements that depend on optimization parameters - the areas of the cross-sections of structural elements (S3.6) for displacement constraints. The values of these displacements are determined during the iterative calculation using the results obtained after proposing an algorithm for solving the problems at the first two stages. The calculation involves the evaluation of all changes in the initial structure according to the real SSS under an applied load (a discrete model of the structure is changed adding arising plastic hinges and modifying the initial coordinates of structural nodes).

While combining all above discussed calculations, the proposed algorithm for solving the optimization problem (S1.1) can be extended as shown in Fig. S7.

For calculating the optimization problem, the possibilities of the created algorithm will be disclosed through the optimization of the cross-sectional parameters of a six-story three-dimensional frame structure. The geometry of the investigated frame and the distribution of added vertical and horizontal loads are presented in Fig. 8S a. The magnitudes of forces make $V_{1}=64,229 \mathrm{kN}, V_{2}=128,457 \mathrm{kN}$ and $H_{1}=53,376 \mathrm{kN}$. The crosssectional areas of structural elements fall in 6 different groups displayed in Fig. 8S a. All elements are made of steel the physical parameters of which present yield strength $f_{\mathrm{u}}=250 \mathrm{MPa}$ and elasticity modulus $E=206,85 \mathrm{GPa}$. Also, geometrically non-linear deformable behavior has been considered.

The created discrete model of the frame contains 69 nodes having 378 degrees of freedom and the elements of two types, i.e. 30 column-type elements and 66 beam-type elements. All of those in the structure are assumed to be compressive-tensile-torsionalflexural in two axial directions. Thus, the total number of internal forces makes 576.

American wide flange $W$ type cross-sectional profiles (ASTM Standard A6/A6M) have been chosen for the optimization problem. For the numerical implementation of the proposed algorithm for optimization purposes, the relationships of the geometrical parameters of the cross-sectional areas of the elements are expressed employing the power function.

Next, deformability limits to the optimized frame will be shortly discussed. The lower limits of the optimized parameters - cross-sectional areas - are obtained from the optimization problem (S3.5) of the structure prior to plastic collapse. The result, according to the selected optimality criterion with $0,1 \%$ accuracy, was obtained following 7 iterations. The dynamics of changes in cross-sectional values and the final result are shown in Table S1. Under the values of the cross-sectional areas of structural elements and load reduction factor $\gamma_{\text {red }}=0,99$, analysis problem (S2.12) is solved and the upper limits of frame displacements are established (displacement values under the plastic collapse of the structure). 


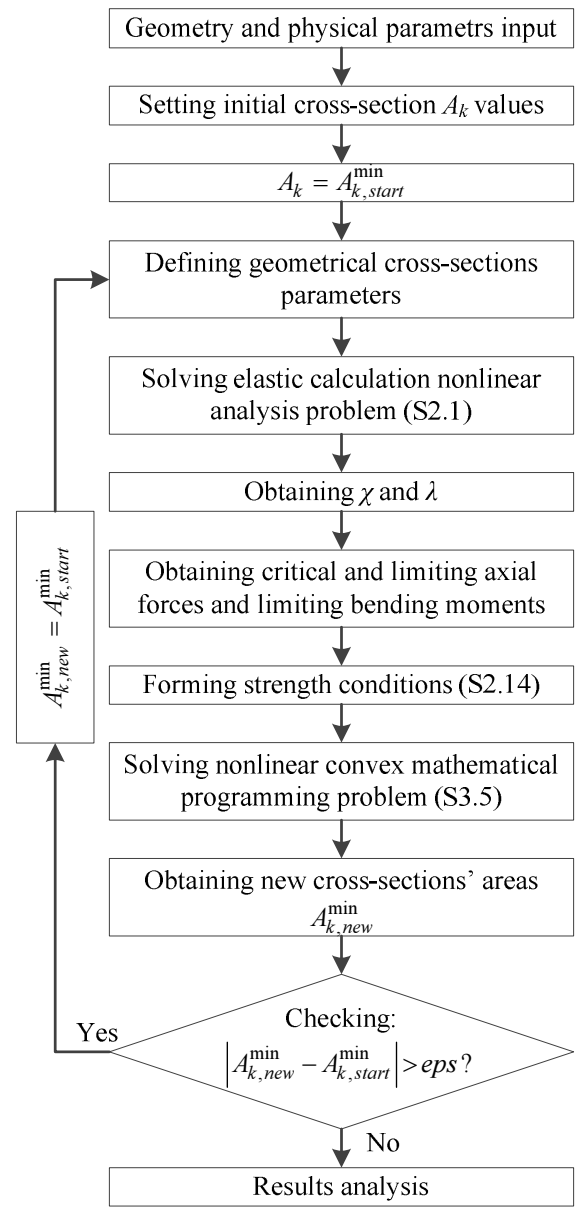

Fig. S6. The algorithm of optimization problem for structure being prior to plastic collapse

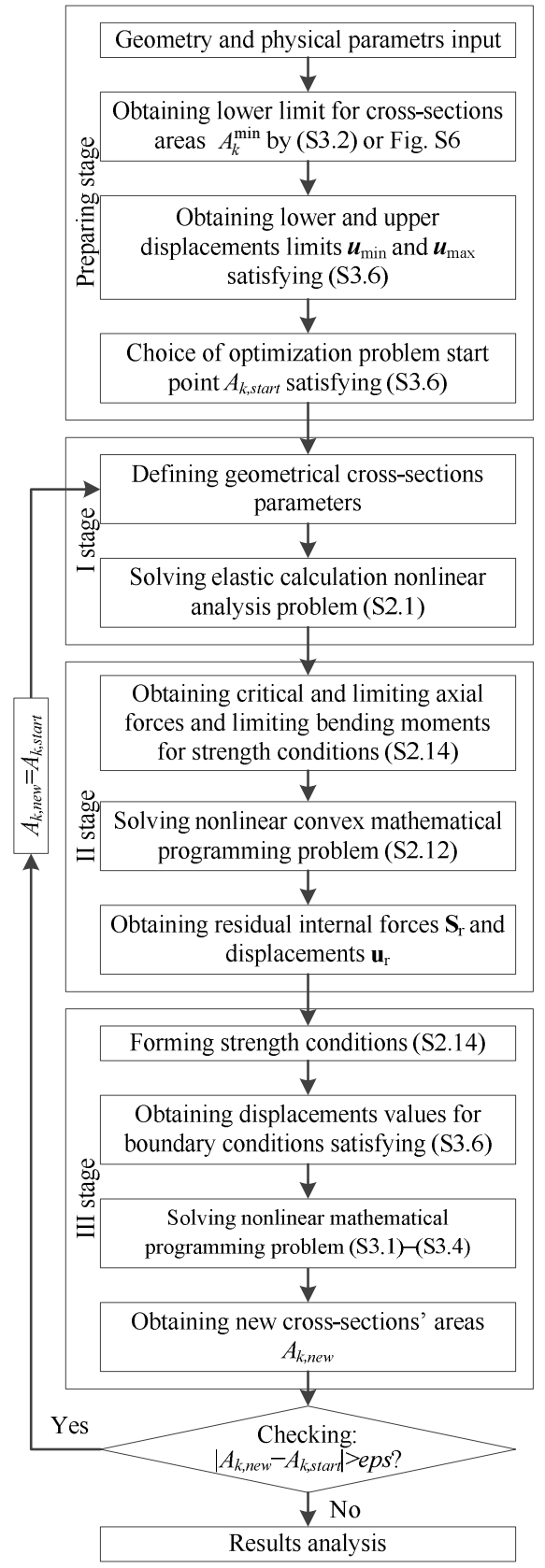

Fig. S7. The extented algorithm of optimization problem solution by suggesting algorithm 
The horizontal displacement of node A in the positive direction of axis $x$ (Fig. S8):

$$
u_{A, x, \max }=u_{e A, x}+u_{r A, x}=17,7310+5,3355=23,0665 \mathrm{~cm} .
$$

The vertical displacement of node B in the negative direction of axis $y$ (Fig. S8):

$$
u_{B, y, \max }=u_{e B, \mathrm{y}}+u_{r B, \mathrm{y}}=-4,8489-2,0112=-6,8601 \mathrm{~cm} .
$$
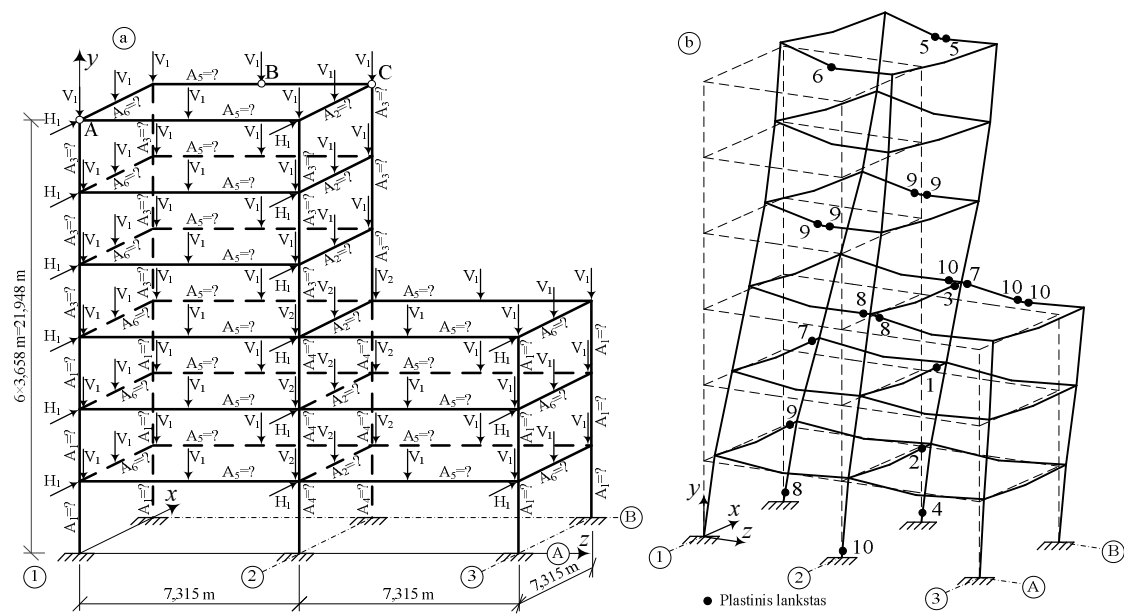

Fig. S8. The discrete model of six-story frame and it's deformed shape under applied load

Table S1. Six-story space frame optimization problem results for structure being prior to plastic collapse

\begin{tabular}{|c|c|c|c|c|c|c|c|}
\hline Iteration & $A_{1}, \mathrm{~cm}^{3}$ & $A_{2}, \mathrm{~cm}^{3}$ & $A_{3}, \mathrm{~cm}^{3}$ & $A_{4}, \mathrm{~cm}^{3}$ & $A_{5}, \mathrm{~cm}^{3}$ & $A_{6}, \mathrm{~cm}^{3}$ & $V, \mathrm{~m}^{3}$ \\
\hline 0 & $\mathbf{1 0 0 , 0 0 0 0}$ & $\mathbf{1 0 0 , 0 0 0 0}$ & $\mathbf{1 0 0 , 0 0 0 0}$ & $\mathbf{1 0 0 , 0 0 0 0}$ & $\mathbf{1 0 0 , 0 0 0 0}$ & $\mathbf{1 0 0 , 0 0 0}$ & $\mathbf{3 , 5 1 1 6 8}$ \\
\hline 1 & 113,2130 & 120,9100 & 69,6722 & 128,3110 & 30,2495 & 112,9014 & 2,7569 \\
\hline$\ldots$ & $\ldots$ & $\ldots$ & $\ldots$ & $\ldots$ & $\ldots$ & $\ldots$ & $\ldots$ \\
\hline 6 & 135,2542 & 112,5077 & 96,5649 & 153,6516 & 29,4167 & 105,7227 & 2,9322 \\
\hline 7 & $\mathbf{1 3 5 , 8 3 2 0}$ & $\mathbf{1 1 2 , 4 6 0 0}$ & $\mathbf{9 6 , 7 4 8 2}$ & $\mathbf{1 5 3 , 9 8 5 4}$ & $\mathbf{2 9 , 4 2 6 3}$ & $\mathbf{1 0 5 , 5 6 1 2}$ & $\mathbf{2 , 9 3 5 1}$ \\
\hline
\end{tabular}

Further, by decreasing load ratio $\gamma_{r e d}=0,8$ and working out the first two stages of the proposed algorithm for the optimization problem (S2.12), displacement values corresponding to the formation of the first plastic hinge are found. For the introduced SSS displacements, the values are as follows:

$$
\begin{aligned}
& u_{A, x, \min }=u_{e A, x}+u_{r A, x}=14,1062+0,1946=14,3008 \mathrm{~cm}, \\
& u_{B, y, \min }=u_{e B, y}+u_{r B, y}=-3,8614-0,0087=-3,8701 \mathrm{~cm} .
\end{aligned}
$$

These are lower limits to changes in frame displacements. Thus, limits to variations in nodal displacements accepted regarding conditions for the problem should be between the following tolerable boundaries: 


$$
\begin{aligned}
& 14,3008 \mathrm{~cm}<u_{A, x}=19 \mathrm{~cm}<23,0665 \mathrm{~cm}, \\
& -3,8701 \mathrm{~cm}<u_{B, y}=-5,5 \mathrm{~cm}<-6,8601 \mathrm{~cm},
\end{aligned}
$$

which ensures the elastic-plastic state of structural work.

For the optimization-iteration process, the appointed initial values of the crosssectional areas of the elements are $5 \%$ higher than those received prior to the plastic collapse of the structure. Upon choosing these particular values of cross-sectional areas as the start point of iterative calculation, and having solved the first two stages of the proposed algorithm for working out the optimization problem, the initial values of restricted displacements satisfying necessary conditions (S3.6) are obtained:

$$
\begin{aligned}
& 14,3008 \mathrm{~cm}<u_{A, x}^{p r .}=22,9039 \mathrm{~cm}<23,0665 \mathrm{~cm}, \\
& -3,8701 \mathrm{~cm}<u_{B, y}^{p r .}=-6,2127 \mathrm{~cm}<-6,8601 \mathrm{~cm} .
\end{aligned}
$$

Having made the iterative calculation of the investigated frame, an optimal project of the selected optimality criterion with $5 \%$ accuracy has been obtained following 7 iterations. The dynamics of changes in the designed parameters within the optimizationiteration process is shown in Table S2. The obtained optimal project of the frame is recorded in Table S2, in the line denoted by number 7. The places of the occurrence of plastic hinges and sequence are presented in Fig. S8, $b$.

Table S2. Six-story space frame optimization problem solution by suggesting algorithm

\begin{tabular}{|c|c|c|c|c|c|c|c|}
\hline Iteration & $A_{1}, \mathrm{~cm}^{3}$ & $A_{2}, \mathrm{~cm}^{3}$ & $A_{3}, \mathrm{~cm}^{3}$ & $A_{4}, \mathrm{~cm}^{3}$ & $A_{5}, \mathrm{~cm}^{3}$ & $A_{6}, \mathrm{~cm}^{3}$ & $V, \mathrm{~m}^{3}$ \\
\hline 0 & 142,6246 & 134,7665 & 104,2538 & 161,6846 & 36,8370 & 152,0807 & 3,5166 \\
\hline 1 & 142,6236 & 113,5846 & 100,4277 & 161,6846 & 33,1045 & 106,6168 & 3,0583 \\
\hline$\ldots$ & $\ldots$ & $\ldots$ & $\ldots$ & $\ldots$ & $\ldots$ & $\ldots$ & $\ldots$ \\
\hline 6 & 155,4948 & 113,5846 & 103,4990 & 161,6846 & 32,6026 & 106,6168 & 3,1217 \\
\hline $\begin{array}{c}\text { (Kim et al. } \\
2001)\end{array}$ & 155,4948 & 113,5846 & 103,4990 & 161,6846 & 32,5632 & 128,3795 & 3,2645 \\
\hline & $\mathrm{W} 12 \times 87$ & $\mathrm{~W} 12 \times 87$ & $\mathrm{~W} 10 \times 60$ & $\mathrm{~W} 12 \times 120$ & $\mathrm{~W} 12 \times 26$ & $\mathrm{~W} 12 \times 53$ & \\
\hline
\end{tabular}

The analysis of the obtained results reveals that the chosen limit values of displacements make an influence on the optimization process, as under an optimal project, these are limited or close to them. Displacement $u_{A, x}=13,8669 \mathrm{~cm}$, which is less than the specified limit value making $19 \mathrm{~cm}$. Displacement $u_{B, y}=-4,2459 \mathrm{~cm}$ is bigger than the specified limit value, which is $5,5 \mathrm{~cm}$. The value of the displacement of node $\mathrm{C}$, under the maximum load value, is equal to $17,33 \mathrm{~cm}$, which is $13,35 \%$ lower than that $(20 \mathrm{~cm})$ obtained by Kim et al. (2001). A important point is that such result of the displacement of node $\mathrm{C}$ has been received under the circumstances when the volume of the material of an optimal structure $\left(3,2645 \mathrm{~m}^{3}\right)$ is $13,23 \%$ lower than that indicated by Kim et al. (2001) in his works $\left(3,7625 \mathrm{~m}^{3}\right)$. 


\section{General conclusions}

1. To approach construction structures to real materials and work conditions it is necessary to consider plastic material properties and geometrical nonlinearity of structure.

2. The efficiency of mathematical programming theory and mechanical principle of extreme energy combination in creation of new mathematical models for geometrically nonlinear elastic plastic construction structures calculation and optimization under displacements constraints.

3. The real SSS values have been obtained by using created geometrically nonlinear elastic plastic structures analysis mathematical mode. The application of Orbison strength for dealing with the problem of elastic-plastic analysis gives best result.

4. The given displacements, which were obtained by using created optimization problem solution algorithm are 13,35\% smaller than values obtained in Kim et $a l$. (2001) work. It is significant to that the optimal volume of the structure in the project is $13,23 \%$ smaller than volume of the structure investigating in Kim et al. (2001) work. It allows to save resources and materials at design and production stages of the project. 



\section{Priedai $^{1}$}

A priedas. Tangentinès standumo matricos nustatymas

A.1. Vykdomosios bylos tekstas

A.2. Gautas simbolinių skaičiavimų rezultatas

B priedas. Ekvivalentinių apkrovos jẻgų nustatymas

B.1. Vykdomosios bylos tekstas

B.2. Gautas simbolinių skaičiavimų rezultatas

C priedas. Dviejų aukštų rèmo analizès rezultatai

C.1. Vykdomosios bylos tekstas

C.2. Tikslo funkcijos bylos tekstas

C.3. Netiesinių Orbisono stiprumo sąlygu bylos tekstas

C.4. Netiesinių AISC-LRFD stiprumo sąlygų bylos tekstas 
D priedas. Šešių aukštụ rẻmo optimizacija plastiškosios suirties etape

D.1. Vykdomosios bylos tekstas

D.2. Tikslo funkcijos bylos tekstas

D.3. Netiesiniu apribojimu sąlygų bylos tekstas

E priedas. Šešių aukštų rẻmo analizès uždavinys

E.1. Vykdomosios bylos tekstas

E.2. Tikslo funkcijos bylos tekstas

E.3. Netiesiniu apribojimu sąlygų bylos tekstas

F priedas. Šešių aukštụ rèmo optimizacija pagal siūlomą algoritmą

F.1. Vykdomosios bylos tekstas

F.2. Analizès uždavinio tikslo funkcijos bylos tekstas

F.3. Analizès uždavinio netiesiniu apribojimu sąlygų bylos tekstas

F.4. Optimizavimo ribojant poslinkius tikslo funkcijos bylos tekstas

F.5. Optimizavimo ribojant poslinkius netiesiniu apribojimu sąlygu bylos tekstas

G priedas. Bendraautorių sutikimai teikti publikacijų medžiagą disertacijoje

H priedas. Autoriaus mokslinių publikacijų disertacijos tema kopijos 
Michail POPOV

TAMPRIŲ PLASTINIỤ GEOMETRIŠKAI NETIESINIŲ STRYPINIŲ KONSTRUKCIJŲ OPTIMIZAVIMAS RIBOJANT POSLINKIUS

Daktaro disertacija

Technologijos mokslai, statybos inžinerija (02T)

Michail POPOV

OPTIMIZATION OF GEOMETRICALLY NONLINEAR ELASTIC PLASTIC FRAMEWORK STRUCTURES UNDER DISPLACEMENT CONSTRAINTS

Doctoral Dissertation

Technological Sciences, Civil Engineering (02T)

201405 15. 11,75 sp. I. Tiražas 20 egz.

Vilniaus Gedimino technikos universiteto

leidykla „Technika“,

Saulètekio al. 11, 10223 Vilnius,

http://leidykla.vgtu.It

Spausdino UAB "Baltijos kopija“

Kareivių g. 13B, 09109 Vilnius 